\title{
Shaping Elements While Maintaining Fit
}

Timo Ritakallio 



\title{
Shaping Elements While Maintaining Fit
}

\author{
Timo Ritakallio
}

A doctoral dissertation completed for the degree of Doctor of Science (Technology) to be defended, with the permission of the Aalto University School of Science, at a public examination held at the lecture hall TU1 of the school on 30 September 2016 at 12 noon. 
Professor Timo Vuori, Aalto University, Finland

Thesis advisor

Professor Tomi Laamanen, University of St. Gallen, Switzerland

\section{Preliminary examiners}

Professor Saku Mantere, McGill University, Canada

Professor Kaj Storbacka, The University of Auckland Business School, New Zeeland

\section{Opponent}

Emeritus Professor Yves Doz, INSEAD, France

Aalto University publication series

DOCTORAL DISSERTATIONS 189/2016

(c) Timo Ritakallio

ISBN 978-952-60-7023-0 (printed)

ISBN 978-952-60-7022-3 (pdf)

ISSN-L 1799-4934

ISSN 1799-4934 (printed)

ISSN 1799-4942 (pdf)

http://urn.fi/URN:ISBN:978-952-60-7022-3

Unigrafia Oy

Helsinki 2016

Finland 
Author

Timo Ritakallio

Name of the doctoral dissertation

Shaping Elements While Maintaining Fit

\begin{tabular}{|c|c|c|}
\hline \multicolumn{3}{|l|}{ Publisher School of Science } \\
\hline \multicolumn{3}{|c|}{ Unit Industrial Engineering and Management } \\
\hline \multicolumn{3}{|c|}{ Series Aalto University publication series DOCTORAL DISSERTATIONS 189/2016 } \\
\hline \multicolumn{3}{|c|}{ Field of research Strategic Management } \\
\hline Manuscript submitted 18 May 2016 & Date of the defence & 30 September 2016 \\
\hline \multicolumn{2}{|c|}{ Permission to publish granted (date) 19 August 2016} & Language English \\
\hline$\triangle$ Monograph & tion & Essay dissertation \\
\hline
\end{tabular}

\section{Abstract}

Organizational performance is a result of doing many activities well and consistently with one another. While existing research has recognized that the fit between organizational activities is an important determinant of success, there is a need for more study of the processes that organizations use to develop and maintain fit in the presence of environmental change. This thesis set out to elaborate theory on fit development. I used the previous theory as a starting point and to formulate open-ended research questions rather than specific hypotheses. I then used empirical material to build on top of the prior literature and to challenge the prior literature. I did this to extend and refine the existing theories on fit development.

To investigate how strategic fit is developed over time and how emergent and behavioral processes might be related to the process of developing and maintaining fit between organizational elements, I conducted a longitudinal case study of one of the most successful European banks covering its performance from 2000 to 2011. I modeled the organization's activities by using qualitative organizational-system maps to determine how the activities evolved over time and how the fit between them was maintained. My primary data source was public information about the company's activities and these data were complemented by private interviews.

In contrast to what the previous theory would suggest, I found that the company's core elements themselves underwent major changes through a process that I call shaping, during which the elements' relationships between one another continued to have a fit-like character. This highlights that to understand strategy as a constellation of organizational elements, it is not sufficient to focus on the relationships between the elements, one must also to be mindful of the qualitative nature of the elements themselves and changes in them. Many of these changes are better characterized as "emergent" rather than as "designed."

My findings contribute to the research on the processes that allows companies to evolve toward fit. Siggelkow recognized four processes that a company uses: thickening, patching, coasting, and trimming. I identified a fifth one-shaping-which refers to the process of transforming a core element while maintaining its identity and relationships with other elements. My conclusion is that shaping strategic core elements is an essential way through which companies maintain fit between their core elements and yet transform and grow radically during the periods of volatility and turbulence in the surrounding environment. Therefore, my findings are essential for the research on the processes that allow companies to evolve toward fit.

Keywords Strategic fit, strategic change, activity systems, organizational elements, banking

\begin{tabular}{lll}
\hline ISBN (printed) 978-952-60-7023-0 & \multicolumn{2}{l}{ ISBN (pdf) 978-952-60-7022-3 } \\
\hline ISSN-L 1799-4934 & ISSN (printed) $1799-4934$ & ISSN (pdf) 1799-4942 \\
\hline Location of publisher Helsinki & Location of printing Helsinki & Year 2016 \\
\hline Pages 212 & urn http://urn.fi/URN:ISBN:978-952-60-7022-3
\end{tabular}



Tekijä

Timo Ritakallio

Väitöskirjan nimi

Organisaation toimintojen muokkaaminen niiden yhteensopivuutta heikentämättä

\begin{tabular}{|c|c|}
\hline Ikaisija Perustieteiden korkeakoulu & \\
\hline Yksikkö Tuotantotalous & \\
\hline Sarja Aalto University publication series DOCTORAL D & ГIONS 189/2016 \\
\hline Tutkimusala Strateginen johtaminen & \\
\hline Käsikirjoituksen pvm 18.05.2016 & Väitöspäivä 30.09.2016 \\
\hline Julkaisuluvan myöntämispäivä 19.08 .2016 & Kieli Englanti \\
\hline$\square$ Artikkeliväitöskirja & $\square$ Esseeväitöskirja \\
\hline
\end{tabular}

\section{Tiivistelmä}

Organisaation suorituskyky on seuraus sen toimintojen hyvästä ja toisiinsa nähden johdonmukaisesta suorittamisesta. Tiedetään, että organisaation toimintojen välinen yhteensopivuus, fit, on olennainen tekijä sen menestykselle, mutta vielä tarvitaan syvempää perehtymistä niihin prosesseihin, joita organisaatioilla on käytössään tämän yhteensopivuuden kehittämiseksi ja ylläpitämiseksi jatkuvasti muuttuvassa ympäristössä. Tämän väitöskirjan tavoitteena on täsmentää aiempaa tutkimustietoa strategisen yhteensopivuuden kehittämisestä. Toteutin pitkittäisen tapaustutkimuksen, jossa tarkasteltavana kohteena oli yksi Euroopan parhaiten menestyneistä pankeista vuosina 20002011. Organisaation toiminnot mallinsin hyödyntäen kvalitatiivista systeemikarttaa, jonka avulla pääsin havainnoimaan toimintojen pitkän aikavälin kehittymistä ja niiden välisen yhteensopivuuden säilymistä. Ensisijaisena tietolähteenä käytin julkisesti saatavilla ollutta tietoa yrityksen toiminnoista, jota täydennettiin yksilöhaastatteluilla.

Aiemmista teorioista poiketen analyysini antoi viitteitä siitä, että yrityksen peruselementit itsessään kokivat muutoksia prosessissa, jonka myötä niiden keskinäiset suhteet alkoivat saada toisiinsa nähden yhteensopivia ominaisuuksia. Tätä prosessia voidaan kutsua muokkaamiseksi, shaping. Tämä löydös korostaa sitä, että strategian ymmärtäminen organisaation elementtien muodostelmana edellyttää paitsi keskittymistä näiden elementtien välisiin suhteisiin, myös ymmärrystä elementtien kvalitatiivisesta luonteesta ja niissä tapahtuvista muutoksista. Monet näistä muutoksista ovat paremmin luonnehdittavissa muotoutuviksi (emergent)kuin suunnitelluiksi (designed) prosesseiksi.

Analyysin tulokset edistävät olemassa olevaa tutkimusta liittyen prosesseihin, jotka mahdollistavat organisaatioiden kasvun ja kehityksen kohti yhteensopivuutta. Siggelkow tunnisti neljä prosessia, joita yritykset käyttävät: thickening (sakeutuminen), patching (paikkaaminen), coasting (liukuminen) ja trimming (puhtaaksileikkaus). Tämä tutkimus määritteli viidennen prosessin - muokkaaminen - joka viittaa organisaation peruselementin muutokseen sen identiteetin ja suhteen muihin elementteihin kuitenkin säilyessä.

Johtopäätöksenä voidaan sanoa, että strategisten peruselementtien muokkaaminen on olennainen keino yrityksille säilyttää yhteensopivuus peruselementtiensä välillä ja silti muuntautua ja kasvaa radikaalisti epävakaassa ja turbulentissa ympäristössä. Tästä johtuen tämän väitöskirjan löydökset tuovat keskeisen lisän tutkimukseen organisaatioiden eri toimintojen strategiseen yhteensopivuuteen johtavista prosesseista.

Avainsanat Strateginen yhteensopivuus, strateginen muutos, aktiviteettisysteemi, organisatorinen elementti, pankkitoiminta

\begin{tabular}{|c|c|c|}
\hline BN (painettu) 978-9 & ISBN (pdf) 9 & $2-60-7022-3$ \\
\hline ISSN-L 1799-4934 & ISSN (painettu) 1799-4934 & ISSN (pdf) 1799-4942 \\
\hline Julkaisupaikka Helsinki & Painopaikka Helsinki & Vuosi 2016 \\
\hline Sivumäärä 212 & urn http://urn.fi/URN:ISB & $52-60-7022-3$ \\
\hline
\end{tabular}





\section{ACKNOWLEDGEMENTS}

Writing a doctoral dissertation has been my dream for a long time. When I started this research project, I expected that it would be a time-consuming and demanding project because I worked full-time throughout the process. The research project took much more time than I expected but during the process I learned a lot and my understanding of strategy development increased. I am really happy that I started this research project and I am particularly satisfied that I was capable of writing this doctoral dissertation.

I would like to thank my supervisor Timo Vuori for helping a lot during the many phases of the process. He provided me with plenty of guidance, advice, and feedback during the research process. I would like to also thank my first supervisor, Tomi Laamanen, who guided me towards studying this research topic. In addition I would like to thank Pekka Puustinen and Markku Maula for helping me so much. I would also like to thank Saku Mantere and Kaj Storbacka for their work as pre-examiners and Yves Doz for his work as the opponent.

I would like to thank my friends as well and all other people who have pushed me to complete this research project by cheering me and regularly asking when we can celebrate the completion of my doctoral dissertation.

Last, but not least, I would like to thank the people closest to me. Firstly, my lovely wife Maarit, whose support, cheer, and tolerance for my time-consuming project have been crucial for the success of my doctoral dissertation project. I would also like to thank my wonderful children-my daughter Nina and son Niko-who have helped me in many practical ways during the research project.

Helsinki, August 19, 2016

Timo Ritakallio 


\section{TABLE OF CONTENTS}

1. INTRODUCTION 1

1.1. Organizations as systems of elements 1

1.2. Consistency between organizational elements leads to effectiveness 3

1.3. How to develop and maintain the consistency of elements 4

2. LITERATURE REVIEW 10

2.1. Organizations as activity systems 10

2.2. Interactions between elements and fit 12

2.2.1. Various ways to map interaction 16

$\begin{array}{ll}\text { 2.2.2. The order of fit } & 18\end{array}$

2.2.3. Fit can be achieved in many configurations 21

2.3. Developing fit 22

2.3.1. Bounded rationality 23

2.3.2. Strategy emergence 26

2.3.3. The punctuated equilibrium model $\quad 27$

2.3.4. Siggelkow's four processes $\quad 29$

2.4. Research gaps and research questions 31

2.5. The banking industry 33

2.5.1. A financial market and the banking industry 33

2.5.2. The global financial crisis created a major discontinuity in the banking industry 35

2.5.3. The changing landscape in the European banking industry $\quad 37$

3. DATA AND METHOD 40

3.1. Theory Elaboration 40

3.1.1. How to develop theory 40

3.1.2. Reasoning 41

3.1.3. The theory of theory elaboration 43

3.2. Theory elaboration in my study 47 
3.3. Sampling 50

3.3.1. The banking industry 50

3.3.2. Specific companies in the banking industry 51

3.3.3. The case of Nordea 52

3.4. Data collection and analysis methods 53

3.4.1. Phase 1: A general understanding of the European banking industry and its context 54

3.4.2. Phase 2: Selecting one of the best performers in the peer group in order analyze it in more detail 73

3.4.2.1. Nordea: a historical overview 75

3.4.2.2. Nordea's business structure and organization 76

3.4.2.3. Nordea's financial performance between 2000-2011 78

3.4.2.4. Nordea's business strategy between 2000-2011 82

3.4.3. Phase 3: Analyzing and describing in more detail the organizational-system maps of Nordea 88

3.4.4. Phase 4: Interviews to validate and enrich my perceptions 90

3.4.5. Phase 5: The identification of core elements 91

3.4.6. Phase 6: The quantitative validation of core elements 94

3.4.7. Phase 7: Analyzing change in Nordea's organizational systems

4. DATA DESCRIPTION: NORDEA'S ACTIVITY SYSTEMS BETWEEN $2000-2011$

4.1. Nordea's organizational system in $2000 \quad 106$

4.2. Nordea's organizational system in 2001

4.3. Nordea's organizational system in $2002 \quad 113$

4.4. Nordea's organizational system in $2003 \quad 116$

4.5. Nordea's organizational system in $2004 \quad 119$

4.6. Nordea's organizational system in $2005 \quad 120$

4.7. Nordea's organizational system in $2006 \quad 122$

4.8. Nordea's organizational system in $2007 \quad 124$

4.9. Nordea's organizational system in $2008 \quad 126$

4.10. Nordea's organizational system in $2009 \quad 128$

4.11. Nordea's organizational system in $2010 \quad 130$

4.12. Nordea's organizational system in 2011 
5. FINDINGS: THE EVOLUTION OF NORDEA'S CORE ELEMENTS FROM 2000 TO 2011

5.1. Core element $A$ : The Nordic counties as a home market $(A) /$

A focus on the Nordic region as well as new European markets (A1)

5.2. Core element B: A focus on e-banking (B) / A multi-channel distribution network (B1)

5.3. Core element $\mathrm{C}$ : growing with existing customers $(\mathrm{C})$ / Increasing business with existing customers (C1)

5.4. Core element D: The rapid integration of Nordic businesses (D) / Building an integrated banking group (D1) / Integrated banking group (D2) / One operating model (D3)

5.5. Core element $E$ : A focus on operational excellence $(E) /$ Operational efficiency (E1)

5.6. Core element F: Profitability prioritized over growth $(F) /$ Efficient capital management (F1) / profit orientation (F2)

6. DISCUSSION

6.1. Shaping as a fifth process to describe the creation and elaboration of core elements

6.2. Connecting the Design School and strategy emergence 162

6.3. The contribution to understanding of the banking industry 165

6.4. Managerial implications 171

6.5. Limitations and future research 177

7. REFERENCES

APPENDIX A. THE EVIDENCE OF NORDEA'S ACTIVITY SYSTEMS BETWEEN $2000-2011$ 186

APPENDIX B. FURTHER DETAIL ON THE RESEARCH CONTEXT

\section{FIGURES}

FIGURE 1.

FIGURE 2.
An activity-system map for lkea 
process

FIGURE 3. The Business Strategy Development of

Commerzbank Between 2000-2011

FIGURE 4. The Business Strategy Development of RBS

Between 2000-2011

FIGURE 5. The Business Strategy Development of Standard

Chartered Between 2000-2011

FIGURE 6. Nordea's Business Structure and Organization in January 2001

FIGURE 7.

Nordea's Organizational System in 2000

FIGURE 8.

Nordea's Organizational System in 2001

FIGURE 9.

Nordea's Organizational System in 2002

FIGURE 10.

Nordea's Organizational System in 2003

FIGURE 11.

Nordea's Organizational System in 2004

FIGURE 12.

Nordea's Organizational System in 2005

FIGURE 13.

Nordea's Organizational System in 2006

FIGURE 14.

Nordea's Organizational System in 2007

FIGURE 15.

Nordea's Organizational System in 2008

FIGURE 16.

Nordea's Organizational System in 2009

FIGURE 17

Nordea's Organizational System in 2010

FIGURE 18. Nordea's Organizational System in 2011

FIGURE 19: Transforming core elements and maintaining fit:

Case Nordea 2000-2005

FIGURE 20: Transforming core elements and maintaining fit: Case Nordea 2006-2011

\section{TABLES}

TABLE 1. The Biggest European Banks by Market Capitalization 57

TABLE 2. Consistency in Business Strategy and TSR 59

TABLE 3. The Key Performance Indicators of the Major European Banks Between 2000 - 2011

TABLE 4. Nordea: Net Profit Between $2000-2011 \quad 78$

TABLE 5. Nordea: ROE Between 2000-2011 79 
TABLE 6. Nordea: Total Assets Growth Between 2000-2011 80

TABLE 7. Nordea: TSR Between 2000-2011 81

TABLE 8. Nordea's Key Financial Targets from 2000 to 2011

TABLE 9. Interviews 91

TABLE 10. Nordea's Core Elements Between 2000-2011 102

TABLE 11. The Centrality Measures of the Ten Most Central

Elements in Nordea's Organizational System

Between 2000 - $2011 \quad 104$

TABLE 12. The Transformation Process of Core Elements A, B, C,

$D, E$, and $F$

138 


\section{INTRODUCTION}

\subsection{Organizations as systems of elements}

Organizations consist of several activities or elements that contribute to the operations and performance of the organization. For example, IKEA's activities or elements include modular furniture design, limited customer service, most items in inventory, and in-house design focused on the cost of manufacturing. These activities can be called elements. Elements can be concrete activities, such as low-cost procurement, and more abstract things like culture. Organizational activities or elements can be further divided between those that are core or central versus those that are peripheral or elaborating. Each organizational core element is supported over time by elaborating elements and their role is to do just this (Siggelkow, 2002).

The elements interact with one another. For example, the practice of low-cost procurement can be reinforced by a cost-conscious culture or undermined by a culture that values luxury over price. The importance of interactions has been recognized in previous literature (Thompson, 1967). The organizations can be modeled as a system of interacting elements; in such an investigation one looks at the elements and their interactions. A set of the firm's activities can be called an activity system or an organizational system. The key idea in modeling organizations as a system is to see how various activities interact with another. Organizationalsystem maps of the firm's choices and their interactions provide a useful tool for understanding the structural requirements of change in a system with tight internal fit (Siggelkow, 2001). The activity-systems perspective provides a conceptual toolbox and language with which to communicate and design key managerial tasks (Zott \& Amit, 2010).

Organizational activity systems can be mapped graphically to understand the various Interactions between the elements. An activity-system map, such as the one below for IKEA (Figure 1), shows how a company's strategic position is included in a set of tailored elements designed to deliver it (Porter, 1996). Porter (1996) used the definition activity-system map when he described how a company's strategic position is contained in a set of tailored activities designed to deliver it, whereas Siggelkow 
(2002) constructed maps of organizational systems. Figure 1 depicts an activitysystem map. Any firm has several activities or elements (illustrated with circles in Figure 1) that can be split into core elements (dark gray) and elaborating elements (white). An organizational-system map allows seeing how such activities are linked (the lines between the circles). This kind of organizational-system mapping model provides a useful way for conceptualizing, examining, and strengthening the strategic fit of a company. There are a set of basic questions such as is each activity consistent with the overall positioning? or Could changes in one operation eliminate the need to perform others? (Porter 1996).

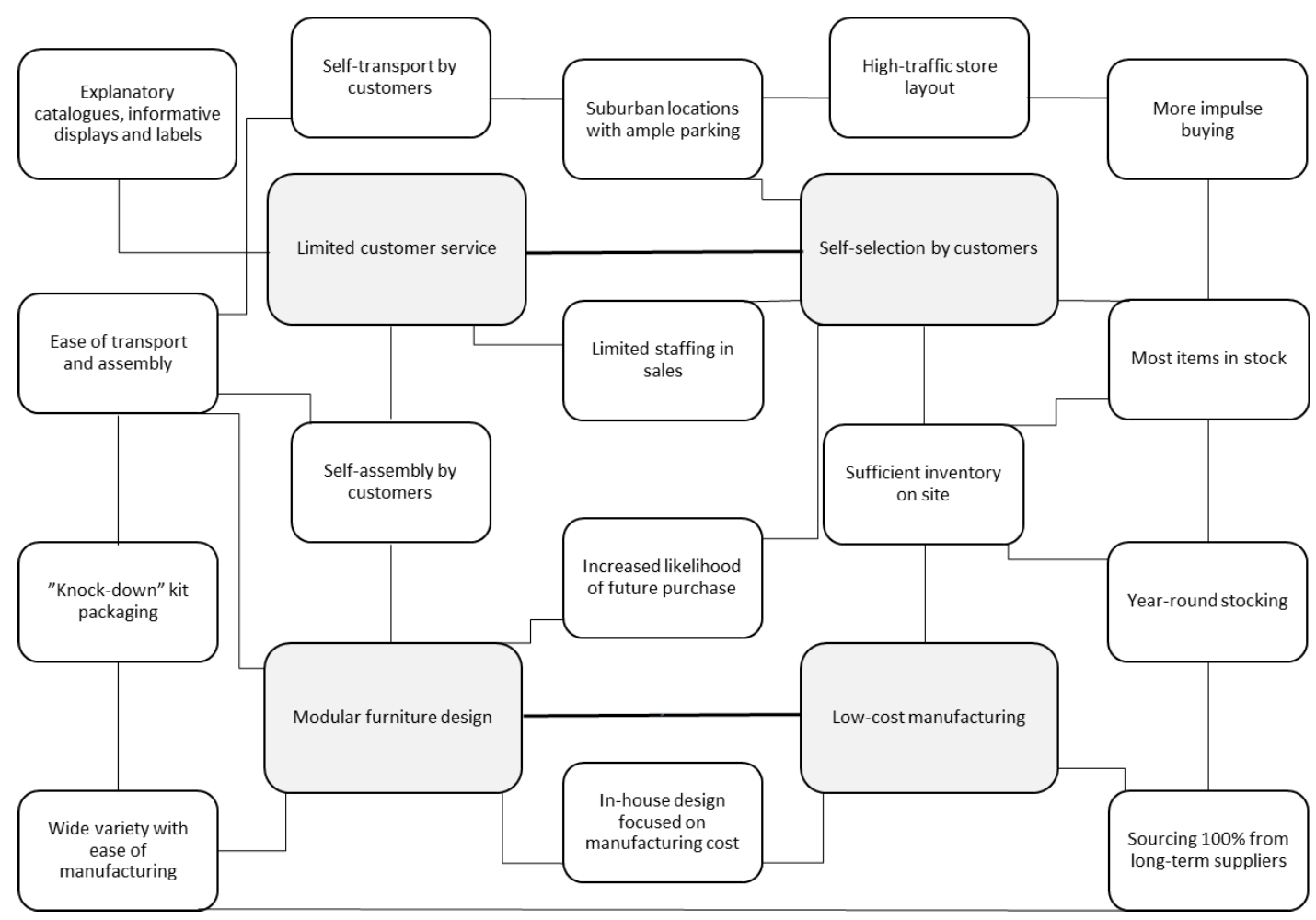

Figure 1: An activity-system map for Ikea, adapted from Porter (1996).

Scholars have found different ways to analyze the consequences of interactions more systematically. Firms have been conceptualized as systems of highly interdependent elements (e.g., Milgrom \& Roberts, 1990; Porter, 1996; Levinthal, 1997; Whittington et al., 1999). The organizational literature also includes multiple 
studies of the consequences of interaction using simulation techniques based on the NK framework developed by Kauffman (Kauffman, 1993). Both the complimentary framework and the NK model have focused on the contextuality of activities; the fact that the value of individual actions is influenced by other activity trade-offs made by a firm (Porter \& Siggelkow, 2008).

\subsection{Consistency between organizational elements leads to effectiveness}

Strategy can be examined as the outcomes of activity choices that, as an interdependent system, essentially influence the current and future performance of a firm (Gavetti \& Rivkin, 2007; Porter \& Siggelkow, 2008; Rivkin, 2000). In the previous literature is the thesis that structure followed strategy (Chandler, 1962), and scholars have recognized that the match between strategy and structure influences performance (Rumelt, 1974). Miller (1986) showed some functional linkages between various complex strategic and structural configurations, and a configuration "can be defined as the degree to which an organization's elements are orchestrated and connected by a single theme" (Miller, 1996: 509). A key target of configuration is form fit or harmony between the elements (Meyer, Tsui, \& Hinings, 1993; Miller, 1996; Normann, 2001). Siggelkow (2002) suggests that there is a high degree of configurational fit if the elements in a configuration with several elements reinforce one another.

The consistency between the elements can be called fit, and fit can be simple consistency between each activity (function) and the overall strategy (Porter, 1996). According to Porter and Siggelkow

a set of activities is said to be consistent if changing any single activity (and not changing any other activity) leads to performance decline. Thus, consistency of fit among activities is represented by a peak in the [performance] landscape [which graphically represents performance as the function of various inter-dependent choices]: Any incremental move leads the firm to a lower elevation, i.e., to lower performance. (Porter and Siggelkow, 2008: 38)

In other words, consistency between elements leads to improved performance. For example, IKEA's strategy of producing low-price furniture is based on a consistent focus on low-cost operations, ranging from flat packing and a refined logistics chain 
to sell-collect warehouses and self-assembly. Consistency improves performance because it improves operational effectiveness, makes the strategy easier to communicate to customers, employees, and shareholders, and it improves the perseverance of the strategy implementation process in the organization (Porter, 1996).

The importance of fit and consistency among a firm's operations is one of strategy's most secular perceptions (Drazin \& Van de Ven, 1985; Khandwalla, 1973; Learned, Christensen, Andrews, \& Guth, 1961), and fit is a more central component of competitive advantage than most realize. Porter (1996) has pointed out the importance of mutually reinforcing activities in creating and sustaining a competitive advantage.

There is considerable empirical evidence of the importance of fit and consistency among a company's operations (Chandler, 1962; Rumelt, 1974). The Vanguard Group (a leader in the US mutual fund industry), for example, organizes all activities with its low-cost strategy by avoiding distribution commissions and minimizing portfolio turnover. Vanguard also gives bonuses to its employees based on cost savings, and it limits, for example, advertising costs (Porter, 1996).

It could thus be concluded that strategy is about combining activities and creating fit among a company's activities, and "the essence of strategy is in the activities choosing to perform activities differently or to perform different activities than rivals" (Porter, 1996: 64). Strategic fit among many activities is fundamental, not only to competitive advantage but also to the sustainability of that advantage.

\subsection{How to develop and maintain the consistency of elements}

Given the importance of consistency, the question of how organizations develop or maintain such consistency is crucial. While existing research has recognized that the fit between organizational activities is an important determinant of success (Porter \& Siggelkow, 2008), there is a need for more study of the processes that organizations use to develop and maintain fit in the presence of environmental change. It is difficult to maintain consistency when external changes or other factors force an organization 
to change, and forming consistency is difficult because it is both difficult to understand the interactions between various elements and routines, and because assets are inertial. There are several theoretical works that touch upon aspects of the process of forming and maintaining consistency.

One of the factors influencing fit development is managers' bounded rationality. A key reason for this is that it assumes "near decomposability" between activities and has therefore paid relatively little attention to the interdependencies and fit between activities (except for political bargaining). Hence, managers may not be able to envision a whole system of activities and all the relevant interdependencies between them. This may cause them to engage in a local search, possibly harming fit development (e.g. Siggelkow, 2002). Gavetti and Levinthal (2000) developed a model of searching in which decision makers form simplified cognitive representations of their decision environment in order to anticipate the long-term implications of alternative courses of action. Overall, this research implies that there are cognitive limitations to how much managers can actually change the overall structure of an activity system in a successful manner.

The research on strategy emergence complements the behavioral theory of the firm. Organizations often do not act according to their original plans but end up taking patterned actions toward some other direction. In this way, strategies often emerge (Mintzberg, 1978). It does not imply mindlessness but rather places emphasis on learning and retrospective sense-making (see also Weick, 1995). Emergent strategy itself implies learning what works and it involves taking one action at a time in order to look for a viable pattern or consistency. Emergent strategy does not mean chaos, but it means unintended order. Emergent strategy does not have to mean that management is out of control but rather that it is open, flexible, responsive, and willing to learn (Mintzberg \& Waters, 1985). Managers may recognize opportunities for development that build on top of their prior actions and are consistent with the prior actions. A high-fit system may thus emerge as the consequence of ad hoc choices taken over the years. However, the strategy emergence perspective suggests to us that high internal fit may develop accidentally, as the outcome of several choices that seek to build on previous ones but without having a master plan for a high fit system in mind from the beginning. 
Punctuated equilibrium models suggest that there are periods of radical transformation (when new fit is created) and performing (when the new fit is used to gain results) (Tushman \& Romanelli, 1985). The basic idea is that high performance requires internal and external fit. The punctuated equilibrium model literature also suggests that companies go through prompt and radical renewal after long periods of progressive changes and strategy reinforcement (Gersick, 1991; Tushman \& Romanelli, 1985). Some scholars (Greenwood \& Hinings, 1996) have recognized radical evolutionary change as a type change, although there is very little understanding of how this type of change occurs. According to the punctuated equilibrium theory (Gersick, 1991; Romanelli \& Tushman, 1994), small changes do not accumulate into big ones.

Further a way to understand fit development is to look at the elements and their changes more closely. Siggelkow (2002) made an inductive study of the developmental path of the second largest mutual fund provider in the United States, the Vanguard Group. First he identified the most central elements in Vanguard's organizational system in a certain year and then he analyzed Vanguard's organizational system for each subsequent year, for which he constructed a map of the organizational system. In contrast to the punctuated equilibrium model, Siggelkow's $(2001,2002)$ work suggests that organizations use four different processes for developing fit over time; patching, thickening, coasting, and trimming. These activities refer to operations such as adding a new elaborating element to an existing core element in the organizational system or removing some elements. They thus put a closer focus on how an organization may adopt new core elements into the organizational system over the course of its history. When an organization adopts new elements into its organizational system, most new elements are not new core elements but reinforce existing core elements.

Siggelkow also pointed out that "the question of when and how firms modify their core elements cannot be addressed with the present study" and "while the literature on punctuated equilibrium would suggest that when firms change their core elements, the process is quick and wide-encompassing, future research is required to investigate whether and when such a process might take place" (Siggelkow, 2002: 157). 
However, while these four processes advance our understanding beyond bounded rationality, strategy emergence, and the punctuated equilibrium models of organizational change by providing a more fine-grained understanding of the change processes, they may not provide a complete picture of organizational activity system change under uncertainty. It may be that organizations also use other types of processes to change and that these other processes make a difference for performance. How a firm modifies its core elements over time is an interesting research gap and therefore it is relevant to investigate the phenomenon more carefully.

In addition to having noted that our understanding of the fit development process is still fragmented, it should be noted that much of the theory built around the idea of organizations as activity systems has its roots in perspectives that treat strategy as a designed and planned activity (e.g., Porter, 1980) rather than as an emergent process (Mintzberg, 1978; Mintzberg \& Waters, 1985) that is much influenced by behavioral considerations (March \& Simon, 1958). However, the perspectives that put more emphasis on emergence and behavioral aspects could further inform the study of how organizations develop strategic fit over time. It may be that the elements are not envisioned at a relatively early stage and implemented according to a plan. Rather, new patterns might emerge and some of the elements might themselves change.

Furthermore, the previous literature has mainly focused on the relationship between elements that are assumed to be stable. Yet, the strategy emergency literature suggests the possibility that the elements themselves could also change over time. This would enable organizations to renew but might also compromise the fit between the elements. While existing research has recognized that fit between organizational activities is an important determinant of success (e.g. Drazin \& Van de Ven, 1985), there is a need for more study of the processes that organizations use to develop and maintain fit in the presence of environmental change.

This study seeks to elaborate theory on fit development. Building on the prior literature, I use a theory-elaborating research approach in this study. That is, the previous theory gives a starting point and helps to formulate open-ended research 
questions rather than a specific hypotheses. The empirical material is then used to build on top of the previous literature and also to challenge the previous literature. This is done in order to extend and refine the existing theories on fit development.

To investigate how strategic fit is developed over time and how emergent and behavioral processes might be related to the process of developing and maintaining fit between organizational elements, I conducted a-theory elaborating study of a top performing European bank between 2000-2011. In contrast to what previous theory would suggest, I found that the company's core elements underwent major changes while their relationships between one another continued to have a fit-like character. This highlights that in order to understand strategy as a constellation of organizational elements it is not sufficient to focus on the relationships between the elements but also to be mindful of the qualitative nature of the elements and changes in them. Many of these changes are better characterized as emergent rather than as designed.

I conducted my study in the banking industry because the banking industry has several characteristics that make it optimal for studying fit development over time. The business models of banks have been changing over recent decades. Banks have significantly expanded their activities over this time. Through this expansion banks have incorporated new activities along with their earlier core activities. The role of banks in the financial system has also increased, banks and the financial market have become more tightly integrated, and business models vary in various important ways. The total asset growth of the European banking sector has been more than the GDP growth of the European Union (EU) over the last decade. Consolidation, cross-border integration, and international growth further support my choice to study fit development over time in the banking industry.

The global financial crisis created another major discontinuity in the banking industry and forced companies to once again reconsider their activities and the fit between them. It thus further increased the value of the banking industry as a theoretical sample for my study. I describe the dynamics in some detail to ensure sufficient understanding of the context in which the bank I studied was making changes to its activity system in order to adapt to those contextual changes and grow. 
Internet banking constitutes an important innovation in the financial sector. Internet banking allows banks to reduce costs through the exploitation of economies of scale and scope, to strengthen their market position by providing value-added services for existing customers, and to operate in new markets by attracting new customers (Corrocher, 2006). This technological discontinuity was another major factor influencing the potential fit between different elements while simultaneously creating the need to develop new elements, and thus created pressures that made fit-related dynamics more visible. This again made banking optimal for studying these mechanisms. 


\section{LITERATURE REVIEW}

\subsection{Organizations as activity systems}

An organization consists of several activities that contribute to the operations and performance of the organization, and these activities can be called elements. Such a set of activities or elements can further be called an activity system or an organizational system (Porter, 1996; Siggelkow, 2002).

Scholars have defined that organizational elements can be firms' activities, policies, structural elements, and resources (Levinthal, 1997; Milgrom \& Roberts, 1990; Miller, 1981; Porter, 1996; Whittington, Pettigrew, Peck, Fenton, \& Conyon, 1999). For example, Southwest Airlines' activities include activities or elements, such as limited passenger service, short-hauls, point-to-point routes between midsize cities and secondary airports, and lean, highly-productive ground and gate crews. As another example, Vanguard's activities include activities or elements-such as direct distribution, strict cost control, and the efficient investment management approach—offering good, consistent performance (Porter, 1996).

Organizational activities or elements can be further divided between those that are core or central versus those that are that are peripheral or elaborating. Hannan, Burton and Baron (1996) have argued that

a feature forms part of the organizational "core" if changing it requires adjustments in most other features of the enterprise. A feature lies at the periphery if it can be changed without imposing changes on other features ... Coreness means connectedness, elements in the core are linked in complicated webs of relations with each other and with peripheral elements elements.(Burton \& Baron, 1996: 506)

Even though in the organizational literature there is no consensus of what specific elements should be included in an organization's core, there exists consensus on the properties of an organizational core element. Some organizational elements are more central or core to an organization than other, more peripheral elements (Hannan \& Freeman, 1984; Singh, House, \& Tucker, 1986).

To first consider the varying definitions of "core," Hannan and Freeman (1986: 156) recognized the "core aspects of organization" that were (1) stated goals, (2) forms 
of authority, (3) core technology, and (4) marketing strategy. These four core aspects provide a possible basis with which to classify organizations into forms for ecological analysis. Siggelkow argues that an element belongs to the core if it has one the following features: "(1) a high interdependency with other organizational elements and (2) a large influence on future organizational elements." (Siggelkow, 2002: 127). Siggelkow (2002: 127) has also defined that "an organizational core element is an element that interacts with many other current or future organizational elements." In testing the punctuated equilibrium model, Romanelli and Tushman (1994: 1147) argued that organizational culture, strategy, structure, power distributions, and control systems are "important to organizational survival and central to activities" and thus form core activity elements (Romanelli \& Tushman, 1994). In one previous study on quantum changes (Miller \& Friesen, 1982) structural transformers were measured and fell into three categories (uncertainty reduction, differentiation, and integration) when they were identifying the core elements of an organization.

In practice, in many studies the core elements of organizations have been identified by presenting a number of critical activity areas ex ante and then selecting variables that represent these areas (Siggelkow, 2002). Each organizational core element is supported over time by elaborating elements, which are defined as organizational elements that strengthen existing core elements (Siggelkow, 2002).

In this dissertation I identified a core element as an element that interacts with many other current or future organizational elements or that has a large influence on future organizational elements. I did this because I wanted to analyze and describe in more detail organizational maps that compromise elements and interactions of the studied company during the study period. I tried to also understand the nature of core elements and the underlying developmental processes that may lead to configurations. To identify core elements, the notion of interactions among the elements of an organizational system plays a key role.

One can also consider organizational elements from the point of view of business models and definitions of business model often include the following core elements: customer value creation, earnings logic, value network, resources and capabilities 
(core competency) and/or strategic decisions, choices or principles (e.g., target market, target customer, etc.). A firm's business model has been conceptualized as a system of interdependent activities that "transcends the focal firm and spans its boundaries" (Zott \& Amit, 2010: 216). According to this study a business model can be viewed as a template of how a company manages business, how it delivers value to stakeholders, and how it links elements and product markets. In another study (Albert, 2013) planned to "explore the role of activity domain characteristics on the likelihood of recombination within the activity system" (2013: 95). Business models represent a wider conceptualization of value creation that catches the transition towards networked value creation (Zott \& Amit, 2008). There is no commonly accepted definition of business model, but according to one definition (Storbacka, Frow, Nenonen, \& Payne, 2012: 60) and based on another analysis (Storbacka \& Nenonen, 2011), business models are "constellations of interrelated design elements, outlining the design principles, resources and capabilities (i.e. design layers) related to markets, offerings, operations and organization (i.e. design dimensions)." Business model design is a crucial task for managers when they are evaluating and rethinking an old business model to make their firm's fit for the future (Zott \& Amit, 2010). In the academic literature it is realized that a better understanding of this is needed, as well as a better understanding of value creation in the wider context of a network, where value can be co-created among diverse operators within the value-creating systems (Nenonen \& Storbacka, 2010). Storbacka and Nenonen (2011: 53 - 54) explain that "the focal actor's business model sets the limits of value co-creation within a network."

This view is useful in my study because most of the core elements that I have used are similar to those Nenonen and Storbacka (2010) realized as core elements when they were studying different business models.

\subsection{Interactions between elements and fit}

Organizations can be modeled as systems of interacting elements. Interactions can exist both between and among elaborating and core elements. The interaction can be positive or negative. The idea is that when organizational elements fit one another, they provide mutually reinforcing benefits that lead to higher performance. 
In contrast, when elements are misfitted, they tend to cancel out each other's effects, harming performance.

Each organizational core element is supported over time by elaborating elements. According to Siggelkow (2002: 128) "an elaborating element usually reinforces at least one core element, and each core element interacts with many elaborating elements. An elaborating element may interact with more than one core element and with other elaborating elements as well." For example, the core element "very low expenses are passed on to clients" interacts with the elaborating element "employee bonuses tied to cost savings" (Porter, 1996: 72). Core elements can also interact with one another. For example "very low expenses passed on to client" can be reinforced by the "direct contribution of mutual funds or by an efficient investment management approach" (Porter, 1996: 72).

The consistency between the elements can be called fit. Fit refers to the positive relationship between activity choices-when fit is high, different activity choices are consistent with one another-and the competitive advantages of activities are related to the concept of fit. The significance of fit and consistency among a firm's operations is one of strategy's most secular perceptions (Drazin \& Van de Ven, 1985; Khandwalla, 1973; Learned et al., 1961). A set of activities is said to be consistent if changing performance it causes performance to decline (Porter \& Siggelkow, 2008). According to one study, consistency (or internal fit) among an organizational elements is positively correlated with performance (Drazin \& Van de Ven, 1985). On the other hand, research about how organizations evolve toward such configurations of tightly reinforcing elements is much less developed (Miller, 1996).

Consistency, coherence, and fit are critical factors in organizational design (Mintzberg, 1981). According to Mintzberg (1981) a root cause for a great many problems in organizational design comes from the hypothesis that organizations are all similar, and the contrary presumption is that effective organizations implement coherence among their component parts and that they do not replace one element without considering the consequences for all of the others. 
If organizations can be modeled as systems of interacting elements, one can investigate the elements and their interactions. The key idea in modeling organizations as systems is to see how various activities or elements interact with one another. The activity-system perspective provides a conceptual toolbox and language with which to communicate and design key managerial tasks (Zott \& Amit, 2010). The activity-system perspective emphasizes the importance of system-level design and it encourages a firm to think in a more systemic and holistic way when designing their business model. Zott and Amit (2010: 222) also suggest that one must consider both "design elements (content, structure and governance) and design themes (novelty, lock-in, complementarities and efficiency)."

Strategy can be considered the outcome of activity choices that, as an interdependent system, substantially influence the current and future performance of a company (Gavetti \& Rivkin, 2007; Porter \& Siggelkow, 2008; Rivkin, 2000). Strategy is about combining activities and creating fit among a company's activities and "the essence of strategy is in the activities - choosing to perform activities differently or to perform different activities than rivals" (Porter, 1996: 64).

When organizations are modeled as activity systems, the fit between the elements of the activity system is an important omen for the success of the organization. It is important to understand the performance of a firm as well as a system of the combined choices in a firm. If some activities are more beneficial to the firm than they are to its rivals, incentives for imitation are silenced and contextual activities can lead to different strategic positioning within an industry (Porter \& Siggelkow, 2008).

Strategic fit among many activities is fundamental not only to competitive advantage but also to the sustainability of that advantage. Competitive advantage comes from the entire system of activities and the fit among activities substantially reduces cost or increases differentiation. If interdependent activities are efficiently operationalized, it can lead to competitive advantage. This is described well in Porter's (1996) analysis of the company Gap: 
The Gap, a retailer of casual clothes, considers product availability in its stores a critical element of its strategy. The Gap could keep products either by holding store inventory or by restocking from warehouses. The Gap has optimized its effort across these activities by restocking its selection of basic clothing almost daily out of three warehouses, thereby minimizing the need to carry large in-store inventories. The emphasis is on restocking because the Gap's merchandising strategy sticks to basic items in relatively few colors. While comparable retailers achieve turns of three to four times per year, the Gap turns its inventory seven and a half times per year. Rapid restocking, moreover, reduces the cost of implementing the Gap's short model cycle, which is six to eight weeks long. (Porter, 1996: 72-73)

According to Porter and Siggelkow (2008: 37) "competitive advantage is more likely to be sustainable if it arises from activities that have more than one optimal configuration, i.e. from strategy-specific activities." For example in the wine industry, two companies, Mondavi and Gallo, have chosen totally different systems of contextual activities. Mondavi focuses on premium wines with handled grapes, a sophisticated production process, heavy use of wine tastings and public relations, etc. Gallo, instead, uses highly-automated production methods and produces large volumes of competitively priced wines. Mondavi and Gallo have different activities that fit together and reflect the firms' different positioning (Porter \& Siggelkow, 2008).

US mutual fund provider Vanguard differs from its competitors in two ways, it focuses on very low expenses and does not aim at outperforming the market but rather aims at matching it. The internationalization of investment management and distribution decreased Vanguard's costs, and these cost savings were passed through to the funds, which therefore implied higher net return. Porter and Siggelkow (2008: 47) found a "complimentary relationship" between the mutual funds Vanguard was focusing on and the kind of funds investment management that Vanguard was insourcing (i.e., low-risk and index funds). Vanguard did not insource the investment management of actively managed funds and this was consistent with the contextual complimentary argument (Porter \& Siggelkow, 2008).

When a company's position is built on systems of activities, it is less easy for competitors to imitate it, and therefore it is far more sustainable. If a company has strategic fit among its activities, it creates pressures and incentives to improve 
operational effectiveness, which makes imitation even harder (Porter, 1996). If an activity is more beneficial for a company than the activity is to the rivals of the company, it creates competitive advantage for the company and this kind of competitive advantage is more likely to be sustainable (Porter \& Siggelkow, 2008). This is partly because a more complex interdependent system builds up a natural hindrance to imitation (Rivkin, 2000). Porter (1996) has pointed out the importance of mutually reinforcing activities in creating and sustaining a competitive advantage.

Some scholars (Miles \& Snow, 1978; Porter, 1980) have suggested in their conceptual works that there are four "dimensions" that reflect important competitive strategies. These dimensions are differentiation, cost leadership, focus and asset parsimony. Danny Miller (1986) suggested a new approach for studying the relationships between strategy and structure, and showed some functional linkages between various complex strategic and structural configurations.

\subsubsection{Various ways to map the interaction}

There has been a long tradition of recognizing the importance of interactions in the organizational literature (Thompson, 1967), and scholars have found different ways to analyze the consequences of interaction more systematically. How to analyze the consequences of interactions in a structured way has been a challenging issue in the strategy field for many years. Two ways have been found that make it possible to analyze them more systematically. Scholars have conceptualized firms as systems of highly interdependent elements and in these analyses organizational elements are seen to form complex systems of configurations (Levinthal \& March, 1993; Milgrom \& Roberts, 1990; Miller, 1981; Porter, 1996; Whittington et al., 1999). One of the most common approaches in this research field is developed by Milgrom and Roberts (1990), the complementarity framework. According to this approach, to understand the performance of a firm, one has to analyze the firm as a system of interconnected choices.

Another way to analyze the strategic and organizational implications of the interrelations between a firm's operations is agent-based simulation modeling using the NK model (Kauffman, 1993), and multiple studies of the consequences of 
interaction effects are made with this simulation technique. Both approaches have emphasized "the contextuality of activities"-(that is to say), the fact that the merit of individual operations is influenced by the other activity trade-offs made by a firm-and neither the complementary framework nor the NK model have been successful in researching the issue of interrelations among a firm's activity choices (Porter \& Siggelkow, 2008). Contextuality has a number of implications for management practice. It is generally challenging to imitate complex systems of interactive activities because the entire system must be replicated and if only a few elements of a system are copied, no benefits are created. Strategy-specific operations and activities are often more difficult and costly to imitate, and the contextuality of interrelations may lead to misinformed imitation behavior (Porter \& Siggelkow, 2008).

An activity-system map or an organizational-system map shows how a company's strategic position is included in a set of tailored elements designed to deliver it. Porter (1996) has used the term activity-system map, whereas Siggelkow (2001, 2002) has used the term organizational-system map. Such maps also create a useful tool for examining and strengthening strategic fit (Porter, 1996). Organizational-system maps of the firm's choices and their interactions provide useful tools for understanding the structural requirements of change in a system with tight internal fit (Siggelkow, 2001). There are a set of basic questions: Is each activity consistent with the overall positioning-the varieties produced, the needs served, and the type of customers accessed? Are there ways to strengthen how activities and groups of activities reinforce one another? or Could changes in one activity eliminate the need to perform another? (Porter, 1996).

Research on the interactions among activities in firms and the dimension in which these interplays help to generate and sustain competitive advantage has rapidly expanded in recent years. Also, economists have been interested in the issues of fit and interdependence among firms' choices and they have created mathematical frameworks for modeling it.

In this study, I use the organizational-system maps because this mode provides me with a conceptual toolbox and language with which to communicate and design the 
key managerial tasks of the studied company. Organizational-system maps of the firm's choices and their interactions provide a useful tool for understanding the structural requirements of change in a system with tight internal fit (Siggelkow, 2001).

\subsubsection{The order of fit}

There are three levels of fit. "Fit" refers to the positive relationship between activity choices so that when fit is high, different activity choices are consistent with one another. The competitive advantage of activities is related to the concept of fit. According to Porter (1996: 71) first-order fit is "simple consistency between each activity (function) and the overall strategy." Consistency has the role of ensuring that the competitive edges of functions cumulate and do not erode or cancel themselves out. Second-order fit occurs "when activities are reinforcing." Thirdorder fit "goes beyond activity reinforcement ... optimization of effort" (Porter, 1996: 72). The more a company's positioning rests on activity systems with second- and third-order fit, the more sustainable its advantage will be (Porter 1996). Milgrom and Roberts (1990) have pointed out that one activity's value increases in the presence of one or several other activities and vice versa.

Organizational fit can be further divided into internal and external fit. Internal and external fit are both important. Both types of fit have been studied actively within management and organizational literature. For example, Japanese manufacturing methods were analyzed, especially in the late 1980s and 1990s and in the studies the importance of replicating entire systems of practice was recognized (Jaikumar, 1986).

Internal fit refers to the fit between the strategy and the structure of firms (Chandler, 1962; Learned et al., 1961). Historically, the consistency of a higher level fit between "strategy" and "structure" is crucial (Chandler, 1962) and influences performance (Rumelt, 1974). Some researchers for their part consider strategy and structure from a more multidimensional point of view (Miles \& Snow, 1978; Miller \& Friesen, 1978; Miller \& Friesen, 1977). Scholars have given inductive and experiential reasons for why a firm's strategy and its structure, and its managerial 
processes have to fit one another. They realized as well that the challenges in implementing fit, especially under the circumstances of changing a firm's design and processes to fit new strategies. If a firm has many organizational elements that strengthen each other, it is said to have a high degree of internal fit (Siggelkow, 2001). This assumption of fit is consistent with Miller's (1996: 511) proposition that "the fit among the elements of an organization may be evidenced by the degree to which strategy, structure and systems complement one another" (Miller, 1996). Internal fit between choices can lead to a sustainable competitive edge because it makes imitation difficult for rivals (Rivkin, 2000). According to Porter and Siggekow (2008):

Consistency, or internal fit within a set of activities, is represented by a peak in the landscape. A set of activities is said to be consistent if changing any single activity (and not changing any other activity) leads to a performance decline. Thus, consistency of fit among activities is represented by a peak in the landscape: Any incremental move leads the firm to a lower elevation, i.e., to lower performance. (Porter \& Siggekow, 2008: 38)

External fit refers to the fit between the structure and the environment of a firm (Burns \& Stalker, 1961; Lawrence \& Lorsch, 1967; Thompson, 1967). Often, environmental changes reduce external fit, which makes changing internal elements (structures and processes) necessary (Miller, 1992). This increases the risk of breaking the internal fit. Environmental contingency is said to claim delegation of authority (Burns \& Stalker, 1961; Thompson, 1967), organizational differentiation and specialization (Lawrence \& Lorsch, 1967; Thompson, 1967), and elastic, unofficial decision-making (Miller \& Friesen, 1984). Miller (1992: 159) found in his study that "fit with environmental diversity did not have any implications for internal fit."

Siggelkow (2001: 839) suggests that external fit is "the appropriateness of the configuration given the environmental conditions facing the firm." Environmental changes can be thought of as changing the landscape of a firm. One example of that is the case with car manufacturer Ford in the early 1900s. Ford chose a lowvariety and low-flexibility production system and it was possible to implement this system very efficiently because of the information and production technologies available at the time. By the 1980s, the landscape had changed and choosing a high variety with high flexibility become technologically feasible, and since then the 
value of Ford's production had declined and a new production system by Japanese car makers had arisen and formed a higher-performance set of choices.

According to one study, a tight fit may make a firm more sensitive to environmental change (Weick, 1976). Scholars have also presented a framework for thinking about the relationship between fit and organizational inertia when a firm is confronted with environmental change (Siggelkow, 2001). Accordingly, organizational adaptation may be hindered if a radical environmental change requires making changes to several activities at once. This happens because managers often fail to see all the interdependencies between the elements of their activity system and therefore change only a portion of them-destroying the fit between the elements. There are also factors that may cause senior management to fail to respond to environmental changes. Both previous success and strong organizational identities have been found to increase belief in an organization's relative invulnerability to environmental changes (Miller, 1994; Milliken, 1990). Previous studies have also shown that past success leads to a reduction in information processing (Miller, 1993) and increased intensity of the belief that environmental changes are not going to affect a company negatively (Milliken, 1990). Variable environments require organizational systems to engage in strategic renewal, which is determined as the evolutionary, progressive process of continuously adapting and exploring in order to evoke change in a company's activity choices and outputs (Floyd \& Lane, 2000; Huff, Huff, \& Thomas, 1992).

Mismatch between internal and external fit "is unlikely to be engendered by institutional forces in the environment, by boundary aspects of context, by ritualistic organizational behavior, or by many departmental practices" (Miller, 1992: 162). Miller (1992) has identified three reasons for mismatch between environment and internal fit. Sometimes efforts to achieve fit with the environment can block or destroy internal complementarities. Other reasons are adaption and loose coupling. Some scholars suggested earlier that organizations can be "loosely coupled," both internally and externally (Aldrich, 1979; Glassman, 1973; Weick, 1979). Miller (1992: 161) suggested that the third reason for mismatch between internal and external fit is "tunnel vision," which means that management often skip considering the environment when they are creating efficient and internally consistent 
organizations. This kind of happening can be, for example, a new product launch by a competitor (Miller, 1990).

Miller's managerial conclusion was that managers should perform their adaptive tasks one after the other, trying to reach a harmonious alignment among the internal variables in order to obtain smooth functioning but occasionally disrupting this harmony to adjust to a changing environment (Miller, 1992). The more unpredictable and changeable the business environment of a firm, the more challenging it is for the firm to understand and cope with that environment (Khandwalla, 1977). Fit with uncertainty demands a lot of changes, which destroy complementarities between structure and process (Miller, 1992). According to some scholars organizations that execute the best fit with uncertainty demonstrate the smallest amount of interrelations between structure and process (Burns \& Stalker, 1961; Lawrence \& Lorsch, 1967; Thompson, 1967).

\subsubsection{Fit can be achieved in many configurations}

A key target of configuration is form fit or harmony between elements (Meyer et al., 1993; Miller, 1996; Normann, 2001). A configuration "can be defined as the degree to which an organization's elements are orchestrated and connected by a single theme" (Miller, 1996: 509). Miller (1986) showed some functional linkages between various complex strategic and structural configuration. Miller (1996) has also suggested that the search for configuration itself, (which is a search for complex systems of interrelation and their core orchestrating themes), is choosing different common organizational forms (Aldrich, 1979; Hannan \& Freeman, 1977). Another argument for configuration has been that the organization may be guided toward a common configuration by internal harmonizing of strategy, structure, and context (Miller, 1986). The third argument for configuration has been that organizations try to change their elements in a way that either broaden a given configuration, or transform it quickly into a new configuration that is retained for a very long time (Miller, 1986).

Mintzberg (1981) has described five different configurations: the simple structure, machine bureaucracy, professional bureaucracy, divisionalized form, and adhocrazy. The simple structure is a simple organization with one or a few top managers and a 
group of employees who do the basic work. It is like "the classic entrepreneurial company." Machine bureaucracy emphasizes the standardization of work for cooperation and it provides low-skilled, highly-specialized jobs. Professional bureaucracy emphasizes the standardization of skills rather than work processes or outputs for its coordination. A loose administrative overlay and quite independent entities are typical for the divisionalized form. Adhocrazy is a complex and nonstandardized configuration. A structure of interacting project teams is typical for adhocrazy. According to Mintzberg (1981: 12) "this set of five configurations can serve as an effective tool in diagnosing the problems of organizational design, especially those of the fit among component parts." He emphasized that fit remains an important characteristic.

\subsection{Developing fit}

The previous section showed that fit between activities is important for strategy effectiveness. However, we still lack understanding of how such fit is created.

On a broad level, there are three alternative perspectives on the change and development of organizations. The evolutionary perspective argues that organizational routines are developed during the birth of an organization, and that the organizations stay the same (so environmental change does not influence how organizations do their business). Secondly, contingency theory argues that each organization changes similarly in reaction to an environmental change. Finally, the strategic choice perspective argues that similar organizations might react differently to the same environmental change. Romanelli and Tushman (1986) suggest using a longitudinal research design for investigating which of the three perspectives best explains (or mostly explains) organizational reactions after major environmental changes. In this thesis, I adopt the strategic choice perspective, and this gives the opportunity to consider factors that cause differences in a firm's change pattern.

There are several theoretical works that touch on aspects of the process of forming and maintaining consistency. Next I present four of these approaches. 


\subsubsection{Bounded rationality}

Organizations are important because they provide a lot of input, which develops a manager's qualities and habits. There have been a number of important developments in both individual habits and collective routines, which have been followed to fill a relevant gap in the early Carnegie proposal (see (Parmigiani \& Howard-Grenville, 2011).

In Simon's (1947) book Administrative Behavior he focused on the decision-making process and described how organizations influence the decisions of their members. According to Simon an operational administrative decision should be correct and efficient, and it must be practical to implement with a set of coordinated means. Any decision involves a choice selected from a number of alternatives, directed toward an organizational goal or sub-goal (Simon, 1947). Simon pointed out that an organization is a complex pattern of human communication and relationships.

Cyert and March developed three other sub-theories. A theory of organizational expectations considers how and when an organization searches for information or new alternatives and how information is processed through the organization. A theory of organizational choice needs to characterize the process by which the alternatives available to the organization are ordered and selected. A theory of organizational control specifies the difference between executive choice in an organization and the decisions actually implemented (Cyert \& March, 1963). Some authors have argued that information is not given to the firm but must be obtained, that alternatives are searched for and discovered sequentially, and that the order in which the environment is searched determines the decisions that will be made to a substantial extent (March \& Simon, 1958). Gavetti and Levinthal (2000) developed a model of search in which decision makers form simplified cognitive representations of their decision environment in order to anticipate the long-term implications of alternative courses of action.

March and Simon focused on the history of formal organization. They argued that it is important to take into account the motivational, attitudinal, and rational aspects of human behavior when you are studying human behavior in an organization. They 
pointed out that it is possible to see a decision maker like an information processor (March \& Simon, 1958). Hence, when studying fit development in the empirical part of this dissertation, I will be mindful of the interactions between various units' managers in the political sense. Task allocations are efficient if they are based on similarities in activities (March \& Simon, 1958). In modern terminology, this key idea is named "economies of scope" (Baumol, Panzar, \& Wilig, 1982). Cyert and March viewed an organization as a coalition of stakeholders, with some of these stakeholders organized into sub-coalitions. In their theory of organizational goals they consider how goals arise in an organization, how targets change over time, and how the organization attends to these goals (Cyert \& March, 1963). Cyert and March's coalitional view of organizations has shaped other research during the last decade. Some scholars have examined how the heterogeneity of interests in a firm shaped the adoption of shareholder value creation and increases the decoupling of adoption from implementation (Fiss \& Zajac, 2004). Another study emphasized that while decision-making in corporate governance represents a coalition of members, diverse interests may dominate over problems such as conflicts of interest, exploitation, and the creation of value (Van Ees, Gabrielsson, \& Huse, 2009).

According to Cyert and March the assumptions of rationality that dominated theories before the 1950s can be reduced to two propositions: firms seek to maximize profits and firms operate with perfect knowledge. They criticized these assumptions and pointed out that Gordon, Simon, and Margolis have all argued that profit maximization should be replaced with the goal of making satisfactory profits. Satisfactory profits represent a level of aspiration that the firm uses to evaluate alternative policies (Cyert \& March, 1963).

The behavioral theory of the firm highlighted bounded rationality, political forces, and an aspiration-driven search (Cyert \& March, 1963/1992). A cornerstone of the behavioral theory of the firm is a model in which performance that is below aspirations initiates a search for solutions but also the adaption of the aspiration level towards the actually experienced performance. Overall, while behavioral theory has generated several insights and it has had an enormous influence on organizational theory, strategic management, and the neighboring fields of socio-scientific research, 
it does not provide sufficiently nuanced predictions for developing ex ante testable hypotheses of fit development over time.

Firms do not develop strategies by rationally calculating the expected value of various alternatives and then choosing the best option. In fact, often very little planning takes place. Instead, much of the time firms rely on standard operating procedures and only try to improve things when performance falls below aspirations. This can happen either because the absolute performance has dropped or because the aspiration level has increased (typically due to continued high absolute performance). When they then consider how to reach the aspiration level, they often engage in a local search, considering alternatives one at a time until a satisfactory solution is found (see also March \& Simon, 1958). Expectations are a key driver in any decision-making process (Gavetti, Greve, \& Levinthal, 2012). Cyert and March agree that their theory did not "reflect all of the recent efforts in the psychology of individual choice" (Cyert \& March, 1963). However, the modern management literature mostly equates standard operating procedures with routines (Eisenhardt \& Martin, 2000; Feldman, 2000). In one study of strategic decision-making, it was found that decision rules are more consequential than either top management characteristics, or external or internal contextual factors (Papadakis, Lioukas, \& Chambers, 1998). According to one study, an understanding of the role that routines play in organizational functioning can be obtained through considering the role of individual skills in individual functioning (Nelson \& Winter, 1982).

One of the factors influencing fit development is managers' bounded rationality. A key reason for this is that it assumes "near decomposability" between activities and has therefore paid relatively little attention to the interdependencies of activities and their fit (except when considered in political bargaining). We therefore lack sufficient understanding of how bounded rationality influences processes that are not about unitary choice (what to do in this situation) but relate to the development of an activity system, where the value of a single choice depends on its fit with other activities.

In sum, bounded rationality reduces managers' ability to envision the whole system and consider how any change influences all the interactions. Hence, radical redesign of an activity system is unlikely to maintain internal fit. But we don't really 
know how the process works (expect for the notion of local search suggested by the behavioral theory of the firm).

\subsubsection{Strategy emergence}

The research on strategy emergence complements the behavioral theory of the firm. Organizations often do not act according to their original plans but end up taking patterned actions in other directions. In this way, strategies often emerge (Mintzberg, 1978). It does not imply mindlessness but rather places emphasis on learning and retrospective sense making (see also Weick, 1995).

What are strategies and how do strategies form in organizations? There is no single, globally accepted definition of strategy. According to one definition of strategy it is "a pattern in a stream of decisions" where a decision is defined as a commitment to action; usually a commitment of resources (Mintzberg, 1978). This definition was developed to "operationalize" the concept of strategy; namely to provide a tangible basis on which to conduct research into how it forms in organizations (Mintzberg \& Waters, 1985). Another definition says that a strategy is the pattern of a plan that integrates an organization's major objectives, policies, and action series into a cohesive whole (Mintzberg, Lampel, Quinn, \& Ghoshal, 1998). There are different types of strategies: planned, entrepreneurial, ideological, umbrella, process, unconnected, consensus, and imposed strategies. Planned strategies originate in formal plans, entrepreneurial strategies in central vision, ideological strategies in shared beliefs, umbrella strategies in constraints, process strategies in processes, unconnected strategies in enclaves, consensus strategies in consensus, and imposed strategies in the environment (Mintzberg \& Waters, 1985).

Emergent strategy itself implies learning what works and it is taking one action at time to seek for a viable pattern or consistency. Emergent strategy does not mean chaos, but it means unintended order. Emergent strategy does not have to mean that management is out of control but it can mean it is open, flexible, responsive, and willing to learn (Mintzberg \& Waters, 1985). 
The nature of change might be both radical and continuous and offers a new theoretical explanation of "how small individual adaptations can become radical, transforming an organization in unintended yet dramatic ways" (Plowman et al., 2007). In this kind of case, positive feedback of the change can move the system toward instability until new negative feedback balances it at a new point of equilibrium. It might be possible that similar "small change" dynamics influence fit development in organizational adaptation.

In sum, the strategy emergence perspective suggests to us that high internal fit may develop accidentally, as the outcome of several choices that seek to build on previous ones without having a master plan of a high fit system in mind from the beginning.

\subsubsection{The punctuated equilibrium model}

The punctuated equilibrium model (Tushman \& Romanelli, 1985) suggests that there are periods of radical change (when new fit is created) and performing (when the new fit is used to gain results). The basic idea is that high performance requires internal and external fit. High fit leads to social and structural complexities, and the longer they are developed and iterated, the better the fit becomes, but the complexities also cause inertia and resistance to fundamental changes. The punctuated equilibrium model literature also proposes that companies go through prompt and radical renewal after long periods of progressive changes and strategy reinforcement (Gersick, 1991; Tushman \& Romanelli, 1985). For their part Porter and Siggelkow (2008: 48) suggest that "the fact that interactions can change their type from substitutes to complements, or vice versa, when other activity configurations are altered has consequences not only for imitation but also for the ability of firms to adapt their activity systems."

Convergent periods "refer to relatively long time spans of incremental change and adaptation ... Reorientations are relatively short period of discontinuous change where strategy, power, structure and controls are fundamentally transformed towards co-alignment" (Tushman \& Romanelli 1985: 203). Therefore, as performance declines or the environment changes, an organization may first be resistant to 
change. During periods of convergence, an executive's key role is symbolic behavior and incremental substantive change, whereas in periods of convergence, he or she needs to engage in major symbolic and substantive change activities. For organizations, the key points are to (1) strive for internal and external fit (the longer this is done, the better) and (2) change the rhythm (neither too often nor too rarely).

During periods of radical change, leaders should redesign the organization to match new environmental conditions and executive leadership then needs to initiate a period of reorientation because managers are not able to see the need for this as they are only working to refine the existing system. Recreation is reorientation, which also includes changes in core values. "Reorientations ... are seen as illogical and paradoxical by organization members" (Tushman \& Romanelli, 1985: 203). "Success sows the seeds of extraordinary resistance to fundamental change" (Tushman \& Romanelli, 1985: 205).

Greenwood \& Hinings (1996) recognized radical evolutionary change as a type of change, although there is very little understanding of how this type of change occurs. According to the punctuated equilibrium theory (Gersick, 1991; Romanelli \& Tushman, 1994), small changes do not accumulate into big ones. According to complexity theory, however, when a small change occurs in a context of destabilizing organizational shifts, other small changes are likely to emerge (Plowman et al., 2007). Earlier radical change theorists had emphasized leaders' role in creating and triggering change (Gersick, 1991; Romanelli \& Tushman, 1994), but Plowman, Baker et al. (2007:538) realized "that in emergent radical change, leaders' interpreting adaptations as they begin to accumulate was important". This suggests that fit that maintains radical change could happen through incremental steps-something that the existing models do not adequately explain.

According to one study "firms may have difficulty navigating a changing environment not only because the changes in the environment negate the value of the organization's assets, but also because a tightly coupled organization may have difficulty adapting to such changes" (Levinthal, 1997). This implies how it is difficult to adapt an organization while maintaining fit between elements. 


\subsubsection{Siggelkow's four processes}

In contrast, Siggelkow's $(2001,2002)$ work suggests that organizations use different processes for developing fit over time. Siggelkow has developed a method for determining an organization's core elements and he has identified four processes

that describe the creation and subsequent elaboration of these core elements: thickening (reinforcement of an existing core element by new elaborating elements), patching (creation of a new core element and its reinforcement by new elaborating elements), coasting (no further elaboration of a new core element in a given period), and trimming (deletion of a core element and its elaborating elements). (Siggelkow, 2002: 125)

An organization may adopt many new core elements into the organizational system over the course of its history. When an organization adopts new elements into its organizational system, most new elements are not new core elements but they reinforce existing core elements. Siggelkow (2002) termed the process of adopting a new core element, and its subsequent reinforcement patching. In this dissertation, I have used term patching in situations when a new core element gives rise to a new patch in the map of a company's organizational system.

Siggelkow (2002) termed the process of reinforcing an existing core element with subsequent elaborating elements thickening, because the process leads to an increasingly thick network of interactions involving the respective core element, and over any period of time, any given core element might become further reinforced through the addition of elaborating elements. In my dissertation I have used the term thickening when a new element appeared that was linked to a particular core element or when former elaborating elements were replaced by new ones.

According to Siggelkow (2002) if a core element in an organizational system is not reinforced over a given period of time, the organization is coasting with respect to this core element. In this dissertation I have used the term coasting in this sense. Siggelkow (2002) has termed the process of the deletion of an existing core element and most of its associated elaborating elements trimming. In my dissertation I have used term trimming in this sense. 
The four processes were used to describe an organization's development paths toward configurations-including two new ideal types termed thin-to-thick and patch-by-patch-as well as two known paths between configurations; the punctuated equilibrium path and reorientation through linear progression. Thin-tothick is a type of organizational development that happens when an organization has several core elements that it continues to elaborate over time and it does not add any new core elements. Although core elements stay invariable, individual elaborating elements can change over time. To describe this developmental pattern some scholars have used the terms "entrepreneurial strategy" and "umbrella strategy" (Mintzberg \& Waters, 1985). The patch-by-patch process is different: When an organization is only developing by patching, it thickens its first core element. However the organization creates several new core elements over time and after creating a new core element, the organization dedicates itself entirely to further elaboration of this core element. Some scholars have made a study of firms in the computer industry between 1993 and 1995, and in this study they found one company that transformed itself from a poor performer to a good performer by using this developmental pattern (Brown \& Eisenhardt, 1997).

The four different process identified by Siggelkow allow the description of how organizations develop their strategic fit over time. Some firms might first build operations around one core element, then add another one, and so on. Conversely, others might first build multiple core elements and, over time, build more activities around each core element. However, while the four processes identified by Siggelkow are informative, they are hardly complete. There are theoretical empirical reasons for believing that the fit development process may be more complex than Siggelkow's work allows for. It is possible for example that an organizational core element transforms into a new shape over the course of time. The previous academic literature has not found this kind of development process of a core element in a firm's organizational system.

In his longitudinal case study Siggelkow (2002) focused on the second-largest mutual fund provider in the US, the Vanguard Group, in order to understand the developmental processes that lead to organizational configurations and fit. As a result of this study, the inductive study of the developmental processes went hand- 
in-hand with the creation of a methodology that allowed the identification of the organization's core elements at different points in the organization's history. To identify core elements, the notion of interactions among the elements of an organizational system played a key role (Siggelkow, 2002).

In particular, Siggelkow's (2002) study gives the impression that the mutual fund company that he studied, Vanguard, defined its core elements during the first four years of its existence and then spent over 20 years building its operations around those very same core elements.

Furthermore, Siggelkow notes that an element can be defined as a core element if it has a central role at a future time point, again giving the impression that it was planned from the beginning how the element would eventually be used. But, given the findings made by the scholars focusing on process and emergence, it would be misleading to think that is always the case.

It should also be noted that Siggelkow's (2001) suggestion that configuration and consistency are almost the same as terms is problematic because the term consistency is very close to the term rationality (consistent between objectives and actions), and the term configuration is more extensive because it takes into account social and physiological elements as well.

\subsection{Research gaps and research questions}

Organizational performance is the result of doing many activities well and consistently with one another. While existing research has recognized that the fit between organizational activities is a crucial determinant of success, there is a necessity for more study of the processes that organizations use to develop and maintain fit in the presence of environmental change.

Furthermore, the earlier literature has mainly concentrated on the relationship between elements that are supposed to be stable. Yet, the strategy emergence literature suggests the possibility that the elements themselves could also change over time. This would enable an organization to renew but might also compromise 
the fit between the elements. In addition to having noted that our understanding of the fit development process is fragmented, it should be noted that much of the theory built around the idea of organizations as activity systems has its roots in perspectives that treat strategy as a designed and planned activity (e.g., Porter, 1980) rather than as an emergent process (Mintzberg, 1978; Mintzberg \& Waters, 1985 ) that is much influenced by behavioral considerations (March \& Simon, 1958). However, the perspectives that put more emphasis on emergence and behavioral aspects could further inform the study of how organizations develop strategic fit over time. It might not be that the elements are envisioned at a relatively early stage and then implemented according to a plan. Rather, new patterns might emerge and some of the elements might themselves change.

In sum, while the organizational system and fit literature has provided important insights into organizational adaption and performance, important gaps remain. In particular, with the exception of Siggelkow (2002), the literature has mainly focused on describing the relationship between the elements and their impact on performance. This leaves out three important factors that are studied further in this dissertation, as detailed below.

First, there are the processes that lead managers to initiate changes in their organization's activities. That is, the organizational system does not change itself, but there are managers who make judgments about what is going to be done and what should be done. These managers have certain characteristics that influence their choices (cf. March \& Simon, 1958). More research is needed to understand how managers identify the need to change the configuration of their organization and how they conclude what kind of changes are needed to improve the configuration.

Second, the existing literature treats the elements of an activity system as relatively unchanging and focuses mainly on the relationships between those elements. But it might be that the elements themselves also evolve in more or less planned ways (cf. Mintzberg, 1978). That is, the prior literature tends to assume that a new fit is achieved by generating new elements and/or changing the relationships between elements but leaves out the possibility of changing the elements themselves. 
Third, although researchers have in the past suggested that consistency, or internal fit, between a firm's organizational elements is positively correlated with the firm's performance (Drazin \& Van de Ven, 1985; Khandwalla, 1973), academic research about how firms evolve toward such configurations of tightly strengthening elements is much less developed (Miller, 1996). We know that behavioral factors and emergent processes can influence how the development happens, but these ideas have not been integrated in the current models of how organizations develop fit. That is, neither the work on punctuated equilibrium nor that of Siggelow take their role into account sufficiently.

\subsection{The banking industry}

There are several characteristics in the banking industry that make it optimal for the study of fit development over time. In this section, I extend and elaborate on the reasons that were outlined in the introduction of this dissertation. In this way, I provide an optimal link between the abstract theoretical material described above and the concrete empirical material described in the findings section.

\subsubsection{A financial market and the banking industry}

A financial market is a market where financial assets are exchanged or traded. Financial intermediaries operate in the financial market, providing different services for their customers like the exchange of financial assets on behalf of customers or providing investment advice for them. Financial intermediaries can also exchange financial asset for their own accounts. Financial intermediaries include depository institutions. Commercial banks, mutual savings banks, savings and loan associations, and credit unions are usually called depository institutions (Auerbach 1985; Fabozzi, Modigliani, \& Ferri 1994).

A bank's role has traditionally been to take deposits and make loans to individuals and corporates (commercial banking), to underwrite stocks and bonds, to provide advisory services (investment banking), and to manage assets for individuals and institutions (asset and wealth management services). Banks have significantly 
expanded their activities over time, for instance with dealer and market-making activities, broker activities for professional investors, and hedge funds and proprietary trading. This expansion has meant that they have incorporated new activities that may more or less fit well with their previous core activities. Hence, banks have been influenced by their ability to develop fit, and the processes relating to fit development should be especially visible in banks.

The role of banks in the financial system has increased, banks and financial markets have become more closely linked and integrated, and business models have changed in several important ways. The performance and efficiency of the banking sector has a major impact on a country's overall efficiency and economic performance. Therefore the banking sector's role has increased and is still increasing in countries' economies generally (Ayadi, Arbak, \& De Groen, 2011).

The increased role of financial intermediation is evident from the relative size of the European banking sector in the last decade. Total asset growth was significantly more than GDP growth of the EU for the same period. The total assets of Monetary Financial Institutions in the EU reached $€ 43$ trillion in 2008 (€32 trillion in the euro area), or about $350 \%$ of EU GDP (Liikanen, 2012). The European banking sector is very large by international comparison. For example, in 2010 the US banking sector's assets were only $80 \%$ of US GDP and in Japan the banking sector's assets were $174 \%$ of Japanese GDP (European Banking Federation, 2011). The 26 largest banks and banking groups accounted for $55 \%$ of the total EU banking assets (Ayadi et al., 2011). This means that the European banking market is very concentrated. This all is an additional reason to study the European banking industry-in order to increase understanding of the factors that impact processes that develop strategic fit in banks-because the performance and efficiency of the banking sector in Europe has a large impact on the region's overall efficiency and economic performance. Another reason to study the European banking industry is that several European banks reevaluated and changed their business models obviously after the global financial crisis in 2008.

Over recent decades, the increasing role of banks in the financial intermediation process, the sharp rise in the total assets of the banking sector relative to GDP, the 
market capitalization of banks relative to the overall market capitalization of stock market companies, and the banking sector's share of total profits, which are accounted for in the economy, are clear signs of excessive financialization (Ayadi et al., 2011). This is another reason why studying the banking industry is particularly important-not only does it reveal important theoretical mechanisms that can be analytically generalized to other industries, but, in addition, it yields increased understanding of the factors influencing the viability of the banking industry contributing directly to the well-being of the national and global economy.

\subsubsection{The global financial crisis created a major discontinuity in the banking industry}

The global financial crisis created a major discontinuity in the banking industry and forced companies to (again) reconsider their activities and the fit between them. It thus further increased the value of the banking industry as a theoretical sample for my study. I will describe the dynamics in some detail to ensure sufficient understanding of the context in which the bank I studied was making changes to its activity system in order to adapt to those contextual changes and grow.

The crisis started in the middle of 2007 with the bursting of the housing bubble in the overheated residential real estate market in the US. The prices of US homes had increased by $124 \%$ between 1996 and 2007. At the peak of the bubble, from 2004 to 2006 , about $20 \%$ of all issued residential mortgage backed securities (RMBS) were so called subprime. Because some of these subprime mortgages were pooled, packed, and then sold on further down the chain to investors buying into highly-rated RMBS tranches, investors did not concern themselves about the inability of the underlying borrowers to repay their mortgages. The "originate-to-distribute" model contributed to the decline in underwriting standards (Liikanen, 2012).

The financial stress intensified dramatically in the middle of September 2008 when Lehman Brothers collapsed. After that the crisis truly became as a systemic crisis. As investors in the market realized that large and often complex financial institutions would not always be sold or bailed out, the share prices of banks fell sharply. There were rumors and speculations about the size of Lehman's global portfolio and how 
much banks could lose, and these dominated the market and headlines. Investors ran to safe heavens, like government bonds, and interest rates dropped, especially in the US.

This crisis was the starting point for a development that had different phases that flowed into each other: a specific subprime crisis became a full-blown systemic crisis, the systemic crisis became an economic crisis and then a sovereign debt crisis, which escalated into a set of unprecedented political and economic crises in Europe. Excess leverage and under-capitalization had meant that banks could broaden at a faster rate and to a higher level than would have been possible had they maintained a level of capital comparable with their factual risks, and banks became highly leveraged with a rise in assets on their balance sheet to total equity (Alessandri \& Haldane, 2009).

An important development in the banking sector of most developed countries since the early 1990s was the sharp rise in the speed of financial innovations and the particularly rapid growth of the use of securitization and structured products. Securitization and other credit derivatives were originally designed to shift credit risk and they did just that. But they also changed the nature of risk and transformed credit risk first into liquidity risk, then into a funding risk, because the securitizing banks were unable to sell assets at anything other than fire-sale prices with a huge discount. At the end it was a solvency risk for banks because they were unable to sell assets in order to continue funding by their securitization programs (Ayadi et al., 2011). Because this development had a huge impact on the business models of banking firms, it increased the value of the banking industry as a theoretical sample for my study.

After the dramatic events of 2008, with massive bailouts both in Europe and the US, 2009 was relatively calm for the financial markets. After the global financial crisis a number of financial sector reforms within the EU were adopted.

The global subprime crisis and the resulting credit crunches exerted a major influence on the international strategies of financial services. Ownership structures also changed dramatically when new owners, like governments and sovereign wealth 
funds, acquired major shareholdings in leading financial services firms and this is continuing to change the competitive environment of the sector (Grant \& Venzin, 2009). This change in the competitive environment of banks made the banking industry more valuable and relevant as theoretical sample for my study.

\subsubsection{The changing landscape in the European banking industry}

Banking business is a licensed industry and therefore there are formal barriers to entry, such as legal entry requirements and supervisory approval. There are also informal barriers like economies of scale and scope, reputation, and privileged access to inputs or technology, as well as established sales and distribution networks (Liikanen, 2012).

As the financial markets play a prominent role many economies, there is a clear interest for governments to regulate the financial market and to promote competition and fairness in the market, as well as to promote the stability of the financial system. Financial intermediaries like banks have a key role in the financial system and therefore it is justifiable that there are a lot of regulations to regulate banks and their businesses. Banking regulations include, for example, capital requirements for banks, and a specific minimum level of regulatory capital depends on the level of risk held in its assets.

Both government deposit insurance and too-big-to-fail guarantees of financial institutions are elements that have (and have had) an impact on risk taking in the banking industry globally. According to Ingo Walter, given the unacceptable systemic consequences of institutional collapse, large financial services firms that surpass a given threshold will usually be bailed-out by taxpayers, as was the case during the global financial crisis (2007 - 2009) (Walter, 2009).

The Bank for International Settlements (BIS) is an international organization of central banks from industrialized countries that has played a large role in the internationalization of banking and the regulation of international banking. The BIS had a significant role in the creation of new regulations for banks, like the Basel I and Basel II rules, which include specific minimum capital requirements for banks. 
Rapid growth has been very typical for the financial industry during the last decade. The financial sector profits grew at $16.7 \%$ p.a. between 2000 and 2006 (from \$200 billion euro to $\$ 505$ billion euro), compared with an annual growth of $9.4 \%$ in the first six years of the previous decade (Dore, 2008).

The banking industry has undergone a lot of changes in recent decades due to new regulations, technological developments, and globalization. These changes have also provided new opportunities for competitive differentiation and the banking industry has changed from being supply driven to being more demand led (Mehra, 1996). Globalization has increased integration in the banking industry because the world is more and more one global financial market. Technological innovations like internet banking have allowed banks to not only reduce costs through the exploitation of economies of scale and scope but also to strengthen their market positions by providing value-added services for the existing customers and operating in new markets by attracting new customers (Corrocher, 2006). The European financial services landscape has also changed dramatically. Technological innovations and regulatory changes have been the major forces that have changed the industry's competitive dynamics and the strategic context (Flier et al., 2001b).

Consolidation has been a fact of life in the financial services sector for the last decade, and the structural changes in the banking industry have created the broad strategic turbulence that has challenged top management and boards of banks. Key drivers in this process have been development of information technologies, regulatory changes, and geographic shifts in growth opportunities, as well as the rapid trajectory of client requirements, which have forced banks to revise their strategies (Walter, 2009). The major European banks have significantly increased their international operations and at the same time cross-border integration in the European banking market has significantly progressed, especially in the wholesale market. The adoption of the euro in 1999 and the Financial Services Action Plan were major milestones in the financial integration of Europe. These structural changes in the banking industry have caused the large-scale strategic turbulence and therefore it is relevant and interesting to study fit development, particularly in the European banking industry. 
There are today three major alternative business models in the European banking industry: retail banks, investment banks, and wholesale banks. Retail banks are banks that use customer deposits as the primary source of funding and also provide customer loans (like housing loans) for their clients. Investment banks are active actors in the capital markets and they have substantial trading and derivatives activities. Wholesale banks are banks that are active in wholesale and interbank markets with a focus on domestic business (Ayadi et al., 2011).

For the last two decades classic banking has lost a part of its role in financial intermediation processes to the capital market. At the same time new players have come into the market-like open-end mutual funds, private equity funds, and hedge funds-and they have also taken the role of financial intermediaries. At the end of 2007 mutual fund investments totaled about $\$ 9$ trillion in the US. At the same time total investments in hedge funds were $\$ 1$ trillion (Walter, 2009). Both hedge funds and private equity firms work in co-operation with commercial banks in the lending and securities market to provide leverage for companies that are owned by private equity funds. It means that there is a tight connection between new financial intermediaries and traditional financial intermediaries.

Those new financial intermediaries have contributed more efficiency and flexibility to the market. But their unregulated nature (especially hedge funds and private equity funds) has decreased transparency in the market as well as systemic risk in the financial system.

According to one study, the business models of banks will change after the postcrisis era, in the 2010s. The banking industry is entering a period of slower growth than earlier. New regulation and a supervisory environment will be major driving forces in the future evolution of banks and their business models and strategies. Overall, new regulatory requirements are likely to induce slower growth in banking, higher costs, and lower profitability. All these pressures will impact differently on different banks according to their business profiles (Ayadi et al., 2011). 


\section{DATA AND METHOD}

This method section is structured as follows: First, I describe my research approach to theory elaboration. Second, I present how I used the theory elaboration research approach in my study. Third, I describe my sampling process. Fourth, I present my iterative data collection and analysis processes. There were seven phases in my data collection and analysis process.

\subsection{Theory elaboration}

I used a theory-elaborating research approach in this study. That is, prior literature provided the starting point for my open-ended theory-building efforts. This approach differs from pure hypothesis-based research (in which prior literature is used to develop new hypotheses) in that the research question is more open-ended. Theory elaboration also differs from purely inductive research as the prior literature has a more substantial role in theory elaboration than in purely inductive research.

In this subsection I describe in more detail what I mean by "theory elaboration" and how I used this approach. I start my description by looking at how scientists develop theory and reason in general, and then move to describing the methodological approach.

\subsubsection{How to develop theory?}

What is the way to develop theory? There are different answers to this question from different scholars. Traditionally, scholars have developed theory by bringing together observations from previous literature, common sense, and experience (see e.g., Eisenhardt [1989] who criticizes this traditional view). Some have justified that empirical material has no methodical role in theory building and usually theory is required to be developed either through findings or by the accumulation of authenticated hypotheses. Theory is assumed to match data and some scholars presume that theories increase with more data (Eisenhardt, 1989b; Glaser \& Strauss, 1967). In contrast, some authors have given a more prominent role for empirical material. For example, Alvesson and Kärreman (2007: 1265) emphasized "the 
potential of empirical material as a resource for developing theoretical ideas through the active mobilization of and problematization of existing frameworks." According Alvesson and Kärreman "the role of empirical material is in inspiring the problematization of theoretical ideas and vocabularies." They argued (2007: 1266) that "empirical material can facilitate theorization because it provides resources for both imagination and discipline." Some scholars have pointed out that in essence the challenge of academic research is knowledge production, not knowledge transfer (Ketokivi \& Choi, 2014; Van de Ven \& Johnson, 2006).

Regardless of the prescriptive opinion about the role of empirical material, theory developers engage in reasoning. The next section describes how scientists reason to produce new knowledge. The role of empirical material is partly integrated in these descriptions.

\subsubsection{Reasoning}

What is the target of academic reasoning? It is to argue the case for new knowledge in a scientific field. The new knowledge is often given in the form of theories that explain how and why some concepts influence some other concepts. Theories are thus structured sets of arguments, with sufficient justifications for the arguments made. Proceeding from grounds to consequences in a credible way is the essence of an argument (Toulmin, 2003). According to Ketokivi and Choi (2014: 237) "generally, reasoning can be divided into two categories: computational reasoning and cognitive reasoning." Overall, understanding how scientists reason is important for conducting valid and insightful research.

Reasoning demands the interaction of normative, descriptive, and prescriptive criteria, and only by taking them into account is it possible to develop a set of criteria that are encompassing, rational, and operational in the scientific field (Mantere \& Ketokivi, 2013). On the other hand, reasoning is not a scholar-invariant activity (Faust, 1984; Lipton, 2004). Mantere and Ketokivi (2013:78) have argued that "theory building in practice is simply not researcher invariant." 
It is essential for researchers to understand the logic of different reasoning strategies, because it helps them to build consistency and transparency into how they seek justification, and it also helps assessors to realize which parts of their critique are methodological and which are based on procedures (Ketokivi \& Mantere, 2010). Next I will describe different reasoning strategies. Deduction and induction are separate categories into which reasoning has conventionally been divided. Abduction is a third way of reasoning.

In practice, researchers use all three forms of reasoning in any kind of study. Outlining the formal logic of the reasoning types increases the transparency of my methodological approach as I describe in later sections how some insights emerged through one type of reasoning and how others emerged through other types.

\section{Deductive reasoning}

Deductive reasoning runs from a set of general arguments to a more specific conclusion, and the consequence has to follow analytically from the grounds (Ketokivi \& Mantere, 2010). According to Mantere and Ketokivi (2013: 71) "deductive reasoning takes the rule (1) and the explanation (2) as premises and derives the observation (3)." For example, in this study I used deductive reasoning in my theory building when I noted that (1) people are bounded rationally and (2) managers who are trying to build high-fit organizations are people, and inferred that (3) bounded rationality influences how managers build high-fit organizations.

\section{Inductive reasoning}

In contrast to deductive reasoning, inductive reasoning runs from specific arguments to generalizations (Ketokivi \& Mantere, 2010). According to Mantere and Ketokivi (2013: 71) "inductive reasoning combines the observation (3) and the explanation (2) to infer the rule (1) and, thus, moves from the particular to the general." When a researcher extrapolates from data, his or her inferences are always inductive (Ketokivi \& Mantere, 2010). For example, in this study I used inductive reasoning in my theory as follows: 
- I made the observation that Nordea's core element "a focus on e-banking" was shaped into a new element "a multi-channel distribution network."

- I explained that some intentional activities generated this change and thus explained this observation.

- I inferred the rule that core elements are not stable and can be shaped.

\section{Abductive reasoning}

In abductive reasoning "one begins with the rule (1) and the observation (3); the explanation (2) is inferred if it accounts for the observation in light of the rule" (Mantere \& Ketokivi, 2013: 71). According to Mantere and Ketokivi (2013: 72) "we predict, confirm, and disconfirm through deduction, generalize through induction, and theorize through abduction."

In research practice scholars often use abductive reasoning. Mantere and Ketokivi (2013:81) have summarized the following normative, descriptive, and prescriptive criteria for evaluating abductive reasoning: select the best explanation, have transparency of the selection between alternatives, and comply to local principles in selecting between alternatives. Selecting the best explanation is often subject to discussion between the authors and their audiences (Ketokivi \& Mantere, 2010). In my study, I have explicitly discussed these criteria in relation to my key argument (see "The identification of different processes," p. 99 - 100).

\subsubsection{The theory of theory elaboration}

I used the three forms of reasoning in my theory-elaborating study. Next, I will describe how theory elaboration works in theory.

\section{Theory elaboration's key idea}

Theory elaboration is a process in which empirical material can be used to facilitate and contribute critical reflections: that is, to boost our ability to challenge, rethink, and demonstrate theory (Alvesson \& Karreman, 2007). Theory elaboration concentrates on the contextualized logic of general theory, and in theory elaboration the 
researcher does not search to test the logic of the theory but rather to elaborate it (Ketokivi \& Choi, 2014). This kind of study approach reorganizes the constructed character of empirical data and evidences the constructed character of empirical data and evidences (Astley, 1985).

Ketokivi and Chain (2014: 238) have defined key questions in a decision tree for case research. The first question is What is my research question and knowledge interest? The second question is as follows Do existing theories and literature provide sufficient basis for formulation of the research? If the answer is yes, then the third question is: Is it possible to derive an explicit a priori theoretical hypothesis? If the answer is no, then the next question is it possible to contextualize the a priori theory in other, more general ways? If the answer is yes, then the next question is Can the empirical context and data ultimately lead to more general theoretical insights? If the answer is yes, the theory-elaborating research approach is suitable for implementation. My study passes this formal test, as I describe in pages 47, 48 and 49 .

\section{Forming the research question}

In theory-elaborating research, one formulates the research question based on prior literature but does not develop specific hypotheses. The research question is openended because the prior literature has not provided sufficient guidance for a specific hypothesis. There are various techniques that can be used for formulating the research question.

Usually academic studies create possibilities for contribution by justifying that the existing literature is either incomplete or has ignored an important perspective and that those are gaps that need to be filled (Locke \& GoldenBiddle, 1997). The previous academic studies suggest that gap-spotting is the most prevalent way of generating research questions from prior literature in management science, and scholars usually construct gaps by organizing studies in specific ways (Locke \& GoldenBiddle, 1997; Sandberg \& Alvesson, 2011). 
Alvesson and Sandberg (2011) have developed an alternative approach, which they call problematization methodology. It provides a comprehensive and systematic amendment to gap-spotting and pre-packaged problematization. This methodology enables one to identify, verbalize, and challenge the different types of hypothesis underlying the existing literature, and then to formulate research questions that may facilitate the development of more fascinating and influential theories (Alvesson \& Sandberg, 2011).

According to Alvesson and Kärreman (2007: 1268) "an interesting research problem includes the high potential for an empirical response and a novel insight that adds significantly to - or against - previous understandings." On the other hand, Weick (1989: 525) suggested that "whenever one reacts with the feeling that's interest that reaction is a clue that current experience has been tested against past experience, and the past understanding has been found inadequate" (Weick, 1989).

Practical relevance and practitioners' concerns are things that may have an impact on the choice of research question. Historically, it has been a permanent and challenging problem to understand the relationship between theory and practice for scholars who work, for example, in business schools. These kind of professional schools typically aim at developing knowledge that could be translated into an ability that helps the process of the practice of the crafts (Van de Ven \& Johnson, 2006). In leading academic journals there have been several articles about growing concerns that academic research is less executable for solving problems in business (Bailey, 2002; Rynes, Bartunek, \& Daft, 2001). A part of this criticism has been that the findings of academic studies have not sufficiently been put into practice (Beyer \& Trice, 1982; Hodgkinson, Herriot, \& Anderson, 2001).

Some scholars have argued that the gap between theory and practice is a knowledge transfer problem, complementary, knowledge of theory and practice are separate kinds of knowledge, and the gap is a knowledge production problem (Van de Ven \& Johnson, 2006).

Van de Ven and Johnson proposed four things researchers could do to improve their studies: 
(1) confront questions and anomalies existing in reality, (2) organize the research project as a collaborative learning community of scholars and practitioners with diverse perspectives, (3) conduct research that systematically examines not only alternative models and theories but alternative practical formulations of the question of interest, and (4) frame the research and its findings to contribute knowledge to academic disciplines and to one or more domains of practice. (Van de Ven \& Johnson, 2006: 815)

Regardless of the approach chosen for formulating the research question, data collection is needed.

\section{Collecting and analyzing data}

Having sufficient focus and yet an open research design are key elements in data collection. Once data are collected they should be documented and coded, and the coding of the observations is key in effective case research. It is crucial to try to reduce the date into categories (Glaser \& Strauss, 1967; Miles \& Huberman, 1994). Mintzberg (1979: 536) has pointed out that "no matter how small our sample or what our interest, we have always tried to go into organizations with a well-defined focus to collect specific kinds of data systematically" (Mintzberg, 1979). Without a clear research focus there is a risk of becoming inundated by the volume of data (Eisenhardt, 1989).

The selection of cases is a crucial viewpoint in building theory from case studies, and the concept of a population is critical, because the population determines the set of entities from which the study sample is to be drawn. The aim of theoretical sampling is to select cases that are likely to renew or broaden the emergent theory (Eisenhardt, 1989).

Some scholars have seen empirical material as a resource for developing theoretical thoughts through the active mobilization and problematization of the existing structure (Alvesson \& Karreman, 2007). According to Alvesson and Kärreman "breakdowns offer a vital step in the production of a mystery. Establishing a mystery in itself offers an interesting source of further thinking, since it encourages problematization and self-reflexivity" (2007: 1278). 


\section{Iterative analysis}

New data can challenge literature, leading to revised research question and more data collection. There are different ways in which it is possible to elaborate theory: one can introduce new constructs or one can consider boundary conditions. Successful theory elaboration depends on the scholar's ability to study the general theory and the context at the same time, in a balanced way (Ketokivi \& Choi, 2014). Ketokivi and Choi (2014: 236) argue that "theory elaboration treats the general theory as malleable."

\subsection{Theory elaboration in my study}

My study aims to increase the understanding of the developmental processes that lead to organizational configuration and fit. I used a theory-elaborating approach in this study. The initial literature review provided a research question that I sought to answer with empirical data. Empirical material is then utilized to build on top of the prior literature and also to challenge the prior literature. This is done in order to extend and refine the existing theories on fit development. I found surprising dynamics in the data, which triggered revision of the research question and refining my data analyses. This iterative process ultimately allowed me to contribute to the existing theory of fit development. Next, I will go through the steps of the process in detail.

The theoretical starting point that I chose to use for my study is Siggelkow's (2002) work on evolution toward fit, complemented by a broader understanding of the behavioral theory of firms, strategy emergence, and the punctuated equilibrium model. The theory-elaborating, and perhaps abductive, nature of my study is visible in that I structure the data according to Siggelkow's theory, but I also use the data to challenge the theory. This allows me to elaborate the theory.

In my initial literature review I realized that while the organizational system and fit literatures have provided crucial insights into organizational adaption and performance, important gaps remain. With the exception of Siggelkow (2002), the literature has mainly focused on describing the relationship between elements that 
are assumed to be stable and their impact on performance, and this leaves out three important factors. First, the processes that lead managers to initiate changes in their organizations activities. Second, the existing literature treats the elements of an activity system as relatively unchanging and focuses mainly on the relationships between those elements. Third, although researchers have in the past suggested that consistency, or internal fit, between a firm's organizational elements is positively correlated with the firm's performance (Drazin \& Van de Ven, 1985; Khandwalla, 1973), academic research about how firms evolve toward such configurations of tightly strengthening elements is much less developed (Miller, 1996). I realized that there is a mystery: How do the organizational elements of a firm evolve over time and how is the fit between them maintained? In my study I focused on this mystery.

In next stage of the data analysis, I structured Nordea's strategy development with the help of organizational-system maps. I used Siggelkow's (2002) organizationalsystem map concept for examining and showing how Nordea's strategic position is contained in a set of tailored activities designed to deliver it. An organizationalsystem map is useful for examining and strengthening strategic fit. To identify the core elements of Nordea, the notion of interactions among the elements of an organizational system plays a crucial role. I deal with the organizational system as networks consisting of nodes (organizational elements) and connecting edges (interactions). I analyzed and described in more detail organizational-system maps, compromising the elements and interactions of Nordea. This resulted in a surprise. The labels for the activities that were seemingly the same had changed over the years. I investigated this more closely and recognized that the content of the activities had also changed, even though the organization had adapted (and the activities themselves had changed). I realized that previous literature has not described this kind of phenomenon and decided to focus on it more. Next, I used interviews to validate my observations of Nordea and their organizational system.

After that, I created explicit criteria to define core elements based on previous academic literature. I also applied a systematic procedure for checking all the analyzed data to identify core and non-core elements, and I used a systematic process for coding for interdependencies between recognized elements. Consistent with Siggelkow (2002) and to complement the qualitative validation process, I 
conducted a quantitative validation of the core elements in the organizational-system maps.

In the next stage, I analyzed the changes in Nordea's organizational systems and I systematically coded the data according to Siggelkow's (2002) four processes (thickening, patching, coasting, and trimming), and this concept allows me to describe the developmental path of Nordea consistently. However, I had to develop the fifth concept because the four concepts by Siggelkow did not provide sufficient conceptual tools to describe my data. In contrast to what previous theory would suggest, my findings showed that Nordea's core elements underwent major changes while their relationships between one another continued to have a fit-like character. My findings showed how the top management of Nordea transformed and expanded its strategic core elements into a new shape to emphasize its strategic growth and geographical focus areas in a new way. It was a question about the process of when the strategic leaders of an organization transform or expand the organization's core element into a new shape to emphasize the organization's strategic focus areas in a new way.

\section{Evaluating the quality of my inductive or abductive reasoning}

My reasoning brings together the observations and the explanations in order to conclude with a rule and, thus, move from the specific to the general.

In contrast to what the previous theory would suggest, I found that the core elements of the company underwent major changes through a process in which the elements' relationships between one another continued to have a fit-like character. In my abductive reasoning, I used the following criteria (Mantere \& Ketokivi, 2013):

- (1) Select the best explanation from among the four processes defined by Siggelkow (2002). When they did not provide explanations for all processes I realized that I needed to add the new process, which I defined (see p. 99 - 100) "The identification of different processes.") 
- (2) Focus on the transparency of selection from the alternatives. I ensured the transparency of the selection from the alternatives and defined six different criteria for the processes (see p. 99 - 100).

- (3) Comply with local principles in selecting between alternatives. I used the same defined criteria in the process of the identification of different processes in the developmental path of the studied company.

\subsection{Sampling}

\subsubsection{The banking industry}

To investigate how strategic fit is developed over time and how emergent and behavioral processes might be related to the process of developing and maintaining fit between organizational elements, I chose to conduct my study in the same context as Siggelkow (2002) — the banking industry - to maximize the comparability of my findings. Siggelkow made his longitudinal case study of the second-largest mutual fund provider in the US, the Vanguard Group, whereas I conducted a longitudinal case study of one of the best-performing banking groups in Europe.

The banking industry has several characteristics that make it optimal for studying fit development over time. The business models of banks have been changing over recent decades and banks have significantly expanded their activities over time. The role of banks in the financial system has also increased, and banks and financial markets have become more tightly integrated and business models vary in various important ways. Consolidation, cross-border integration, and international growth further support my choice to study fit development over time in the banking industry.

The global financial crisis caused another major discontinuity in the banking industry and forced companies to (again) reconsider their activities and the fit between them. It thus further increased the value of the banking industry as a theoretical sample for my study. I describe the dynamics in some detail to ensure sufficient understanding of the context in which the bank I studied was making changes to its activity system in order to adapt to those contextual changes and grow. 


\subsubsection{Specific companies in the banking industry}

The second step in my sampling was to identify specific companies from the banking industry. I proceeded in two steps. First, I wanted to increase my overall understanding of the banking industry globally. I used the database Datastream to analyze the financial performance of the top 150 global banks from 1990 to 2006.

Secondly I decided to focus on the European banking industry. I choose the European banking industry as a study sample because it met three distinctive features:

(1) The predominant business model among banks in Europe is the universal banking model. In this banking model banks operate different banking activitiessuch as retail, corporate, and investment banking-and there have historically been no regulations that opposed this concept (e.g., in contrast to the USA).

(2) European banks mostly face similar EU banking laws, regulations, and accounting standards. This guarantees that my sample is homogenous. If my sample would include, for example, Chinese banks, their regulatory environment would be different and therefore making comparisons would be more difficult.

(3) European banks have a more analogous business environment. Business cycles are more similar for European banks than are the business cycles of, for example, Asian banks.

This choice creates a better opportunity to analyze, understand in more detail, and in a consistent way how companies in the same industry and in the same business environment can develop and maintain strategic fit. The results of my study can also help other companies and industries to understand how they can develop and maintain strategic fit.

In my study I wanted to develop an overall understanding of the European banking industry generally and the business strategies of the major European banks from 
2000 to 2011 that would involve how their businesses have developed and performed during the study period.

Next I collected data of the sample under study (comprising 25 major European listed banks and banking groups that are headquartered in the EU). The sample selection exercise aimed to choose the largest 25 banks (as of 2001) in terms of the size of market capitalization.

The 25 banks were chosen based on the following criteria: Their primary activity had to be banking (not the insurance business for example) and they had to have been publicly listed companies over the study period. These criteria ensured both that multi-industry dynamics would not produce noise (which would mask the dynamics relating to the development of internal fit within one industry) and the availability of reliable public data. The sample covers the years from 2000 to 2011 . At the end of the period, in 2011, 18 of the original 25 banks were still left, and six of the original banks had now become a part of one of the other studied major banks.

\subsubsection{The case of Nordea}

To study the underlying processes of organizational development requires a research setting that allows an analysis of an organizational system, consisting of elements and interactions. The argument for focusing on the best performer was that the best performer had a phenomenal capability to maintain strategic fit and shape their business strategies in a consistent way over the study period, while existing theory did not provide a satisfying answer to the question of why and how some firms operating in the same industry, which underwent major changes, were able to maintain consistency and yet adapt while others had to make more radical changes.

According to my preliminary results the best performers in the study group by Total Shareholder Return (TSR) between 2000 and 2011 were Standard Chartered and Nordea. When I compared Standard Chartered and Nordea both banks had had a very clear and focused business strategy over the study period and a good strategic fit. Next I analyzed more carefully and in more detail one of the best performers with 
good strategic fit. When I decided to select Nordea as the bank to analyze more carefully the key arguments for this decision were as follows.

First, Nordea was an interesting new bank created by cross-border mergers, and it was possibility to follow it from the start of the bank.

Second, there was good availability of rich and versatile information on Nordea's business strategy, as well as the possibility to interview key top management people who had been in these key positions from the beginning of Nordea. This information provided an excellent opportunity to gain insights into the story of Nordea. This empirical material was a resource for developing theoretical ideas.

Third, Nordea has had a good strategic fit in its business strategy over the study period, and therefore it was an interesting and relevant case to analyze more carefully in order to understand the developmental processes that lead to organizational configuration and fit.

\subsection{Data collection and analysis methods}

As is typical in qualitative research, the data collection and analyses processes were iterative and, following the logic of theoretical sampling, the focus on my study became sharper after I had conducted initial analyses. It ultimately focused on the development of one company, Nordea. This focus emerged after I had conducted preliminary analyses on 25 (though there were only 18 at the end of the study period) companies as specified above. There were seven phases in the data collection.

See the below figure, Figure 2 (Seven phases in my data collection and analyses process). 


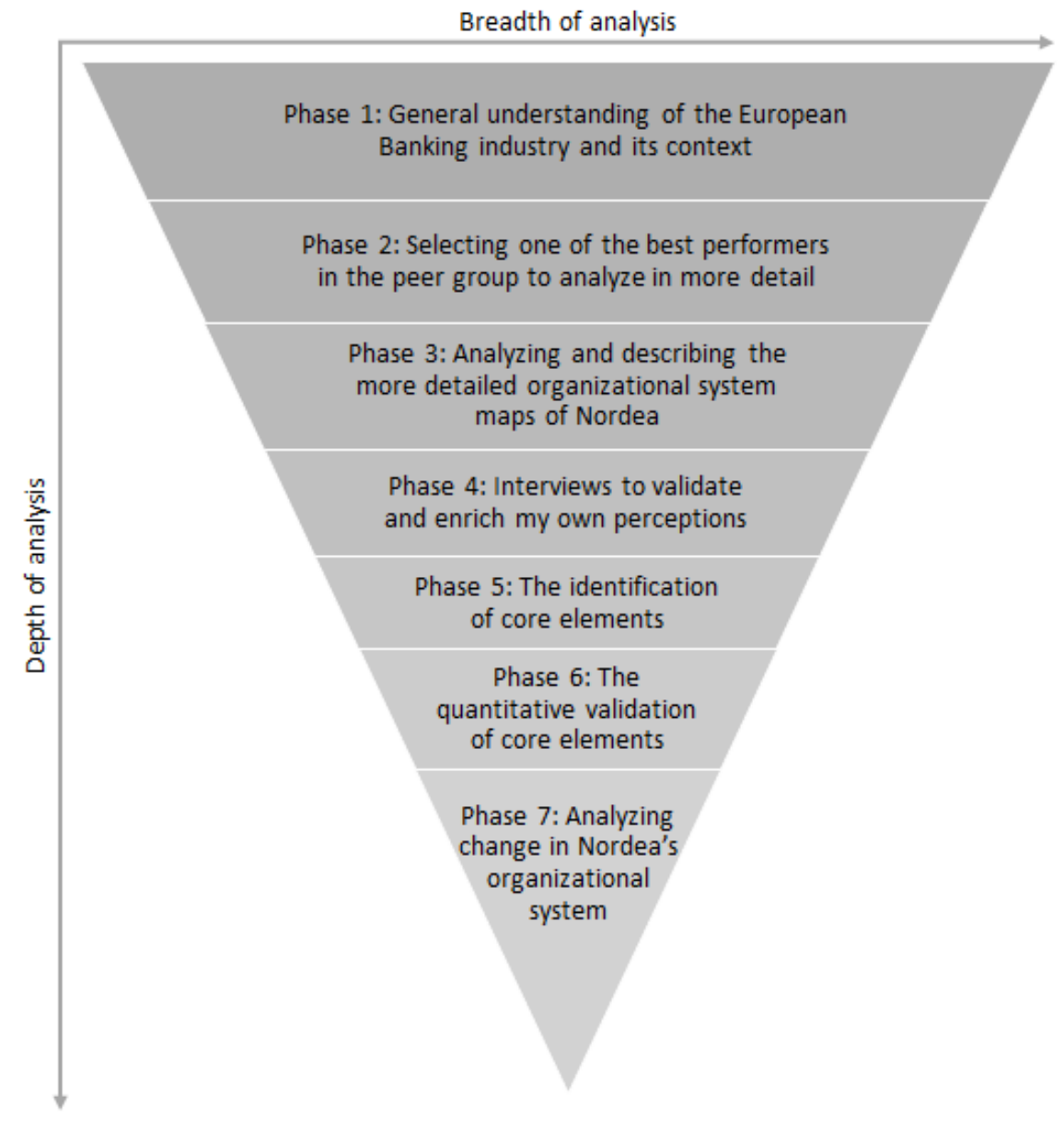

Figure 2: The seven phases in my data collection and analyses process

\subsubsection{Phase 1: A general understanding of the European banking industry and its context}

In the first phase of my data analysis, I wanted to increase my overall understanding of the banking industry globally. I used the database Datastream to analyze the financial performance of the top 150 global banks from 1990 to 2006 by total assets, ${ }^{1}$, return on assets (ROA), ${ }^{2}$ Tier 1 capital and the Tier 1 Ratio, ${ }^{3}$ the nonperforming loans of total assets (\%), ${ }^{4}$ and market capitalization. ${ }^{5}$ There were in total 15300 data points for the studied banks. This created 102 measurements of the 
variables for each of the banks that were among top 150 banks every year over the studied seventeen- year period. Then I made a list of newcomers and losers among the 150 global banks on a year-by-year basis from 1990 to 2006 . I also analyzed the number of mergers and acquisitions made by the studied banks over the study period.

Secondly I decided to focus on the European banking industry. I choose the European banking industry as a study sample because it meets the three requirements. Firstly, the predominant business model among banks in Europe is the universal banking model. In this banking model banks operate different banking activities-such as retail, corporate, and investment banking-and there have historically been no regulations that opposed this concept (e.g., in contrast to the USA). Secondly, European banks face mostly similar EU banking laws, regulations, and accounting standards. Thirdly, European banks have a similar business environment. I wanted to develop an overall understanding of the European banking industry generally and specifically understand what the business strategies of the major European banks were between 2000 and 2011, and how their business has developed and performed during this period.

Next I collected data of the sample under the study, comprising 25 major European listed banks and banking groups that are headquartered in the EU. The sample selection exercise aimed to choose the largest 25 banks (as of 2001) in terms of the size of market capitalization.

\footnotetext{
1) Total assets = the final amount of all gross investments, cash and equivalents, receivables, and other assets as they are presented on the balance sheet

2) $\mathrm{ROA}=$ operating income $\times 100 /$ operating assets

3) Tier 1 capital ratio = Tier 1 capital as a percentage of risk-weighted assets

4) The non-performing loans of total assets $(\%)=$ loans that are overdue (more than 90 days) and full collection of the principal is uncertain as a share of total assets

5) Market capitalization = the ongoing market valuation of a listed company, computed by multiplying the number of outstanding shares with the current share price.
} 
The 25 banks were chosen based on data convenience and availability. The banks had to fulfill the following criteria: their primary activity had to be banking, (not the insurance business for example), and they had to have been publicly listed companies over the study period. These criteria ensured both that multi-industry dynamics would not produce noise (which would mask the dynamics relating to the development of internal fit within one industry) and the availability of reliable public data. The sample covers the years from 2000 to 2011. At the end of the period, in 2011,18 banks of the original 25 banks were still left, and six of original banks were now a part of one of the other studied major banks.

The data sources were the published annual reports and other public Investor Relations (IR) material. In my data analysis I went through all the financial information, interim reports, annual reports and reviews, and other IR material on a year-by-year basis, particularly for the 18 banks that were still left among the study group at the end of 2011. There were 12 annual reports per bank, leading to approximately 280 annual reports with 200 pages per an annual report on average (totaling 56000 pages) and more than 1000 interim reports. My data then gives an approximately 280 bank-year observation. The wide range of performance and other indicators was used related to the financial activity and financial performance of the studied banks. The analyzed 25 banks and banking groups in the sample accounted for more than $50 \%$ of the total EU banking assets, and therefore my study gives large coverage of the European banking industry.

The previous research suggests that a reliable source for corporate strategy and organizational structures can be annual reports (Barr, Stimpert, \& Huff, 1992; Klarner \& Raisch, 2013; Lant, Milliken, \& Batra, 1992). Therefore I concluded that annual reports would be one of the most important information sources in my study.

There is a list of the sampled banks arranged by market capitalization in Table 1. To take into account mergers that have taken place in recent years, all of the largest banks have been included in the database. 
Table 1: The biggest European banks by market capitalization (market capitalization $=$ the ongoing market valuation of a listed company, computed by multiplying the number of outstanding shares with the current share price).

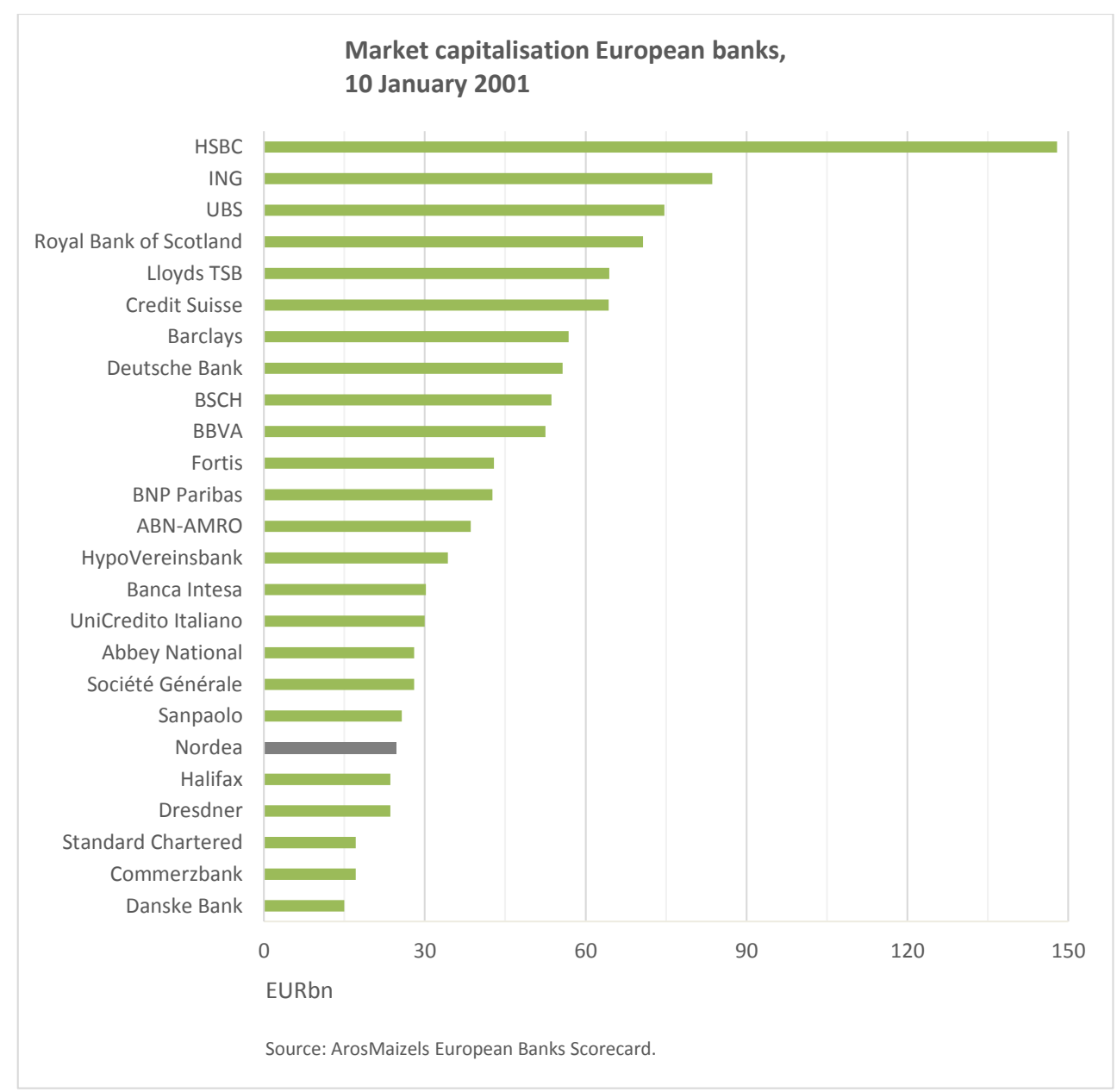

By definition my sample of banks in the European banking industry includes different banks from different European countries, and all of them were among the largest European listed banks as assessed by market capitalization at the beginning of 2001 .

The research period of 2000 to 2011 captures economic growth, globalization, the digitalization of the banking industry, the global financial crisis of 2008, recovery between 2009 and 2010, and the new financial crisis-the Eurozone debt crisis of 2011 
Following the determination of the sample, a database of a large variety of variables was compiled to get a picture of the business strategy and business model, total asset growth, profitability, and TSR. The compilation exercise relied mostly on publicly available data obtained from the banks' annual reports and reviews, interim reports, and other IR material for each year over the covered period (2000-2011). These issues and their implications were evaluated longitudinally for each year.

Archival and secondary data from the period 2000 to 2011 was collected for the case study. The rich set of archival data included company reports like annual reports and reviews, interim reports, Capital Markets Day (CMD) material, and other IR material for the studied banks. All the studied banks were listed banks (whose shares are listed on a stock exchange) whose reports are public information and therefore the transparency of the banks is at a high level. Depending on the bank in focus, there were different sources of secondary data (such as financial and banking journal articles, investment analysis by investment banks, and TSR statistics of the banks by investment banks). In my research I also actively used material on the studied banks published in the leading global banking magazine The Banker over the covered period.

To map out the studied banks' operational systems, I used a longitudinal case-study design (Eisenhardt, 1989). Two methods were used for collecting data: (1) archival data, including electronic, printed, and written material and (2) secondary data, including previous studies and reports on the relevant banking fields. I made a strategy map of all the studied banks 25 and their business strategies over the period covered in the study. Figures 3-5 illustrate such maps for three of the studied banks. These maps were elementary compared to the final ones that I developed for Nordea but sufficiently precise for forming preliminary insights.

When I analyzed the major European banks, their business strategies and their strategic core elements, I realized that the best performers have better strategic fit in their business strategy and their business strategy was more consistent over time. Despite adapting to the changing markets, the successful banks were able to maintain fit between their activities. How they did it started to puzzle me, as the punctuated equilibrium models did not sufficiently explain their adaption and fit, nor 
did Siggelkow's (2002) four processes (thickening [reinforcement of an existing core element by new elaborating elements], patching [creation of a new core element and its reinforcement by new elaborating elements], coasting [no further elaborating of a new core element in a given period], and trimming [deletion of a core element and its elaborating elements]). I realized that the successful banks had some kind of capability to transform their strategic core elements gradually into a new form over the course of time. It seems to be a question of a continuous learning process in the business strategy development.

See the table below (Table 2: Consistency in Business Strategy and TSR).

Table 2: Consistency in Business Strategy and TSR

\begin{tabular}{|c|c|c|c|}
\hline & Lowconsistency & Medium consistency & High consistency \\
\hline High TSR & & Danske Bank & $\begin{array}{l}\text { Standard Chartered } \\
\text { Nordea } \\
\text { HSBC Group } \\
\text { BNP Paribas } \\
\text { Santander }\end{array}$ \\
\hline $\begin{array}{l}\text { Medium } \\
\text { TSR }\end{array}$ & UBS & $\begin{array}{c}\text { Barclays } \\
\text { Societe Generale } \\
\text { Deutsche Bank } \\
\text { Intesa San Paolo }\end{array}$ & BBVA \\
\hline Low TSR & $\begin{array}{l}\text { CreditSuisse } \\
\text { Lloyds TSB } \\
\text { RBS } \\
\text { Commerzbank }\end{array}$ & $\begin{array}{c}\text { ING } \\
\text { Unicredit }\end{array}$ & \\
\hline
\end{tabular}


I assessed the consistency of the banks' strategies using Michael Porter's (1996) view of consistency. He has pointed out that

first-order fit is simple consistency between each activity (function) and the overall strategy. Vanguard, for example, aligns all activities with its low-cost strategy ... Consistency ensures that the competitive advantages of activities cumulate and do not erode or cancel themselves out. (Porter 1996: 71)

I have measured the success of a bank by its TSR over the study period (20002011). According to the results the best performers in the study group by TSR between 2000 to 2011 were Standard Chartered $(+158.1 \%)$ and Nordea $(+114.1 \%)$, and the average TSR for the studied banks was $-23.3 \%$. The worst performers in the study group by TSR during the same period were Commerzbank $-94.7 \%$ and RBS.

Next I present two examples of banks that developed their business strategy less by transforming their strategic core elements gradually into a new form over the course of time and more by making big changes all at one time. These two banks are Commerzbank and RBS. They did not have a capability to transform their strategic core elements gradually into a new form in a consistent enough way, and thus the risk of organizational failure was on a higher level than it was for Standard Chartered or Nordea.

\section{Commerzbank}

The first example is Commerzbank. The bank has a long history, beginning in 1870 when a number of merchants, merchant bankers, and private bankers founded the Commerz- und Disconto-Bank in Hamburg, Germany. As of around 1900, its business focused increasingly on Berlin. It became one of the country's leading big banks with an extensive branch network. In 1940, the name Commerzbank Aktiengesellschaft was officially adopted. With the division of Europe after the Second World War, Commerzbank lost some $45 \%$ of its premises. The process of the decentralization of the big banks in West Germany resulted in a breakdown into three regional banks, which were united in 1958 as Commerzbank Aktiengesellschaft. Commerzbank stepped up its retail banking activities and built up a nationwide network (source: www.commerzbank.com). 
See the figure below (Figure 3) of Commerzbank's business strategy development between 2000 and 2011.

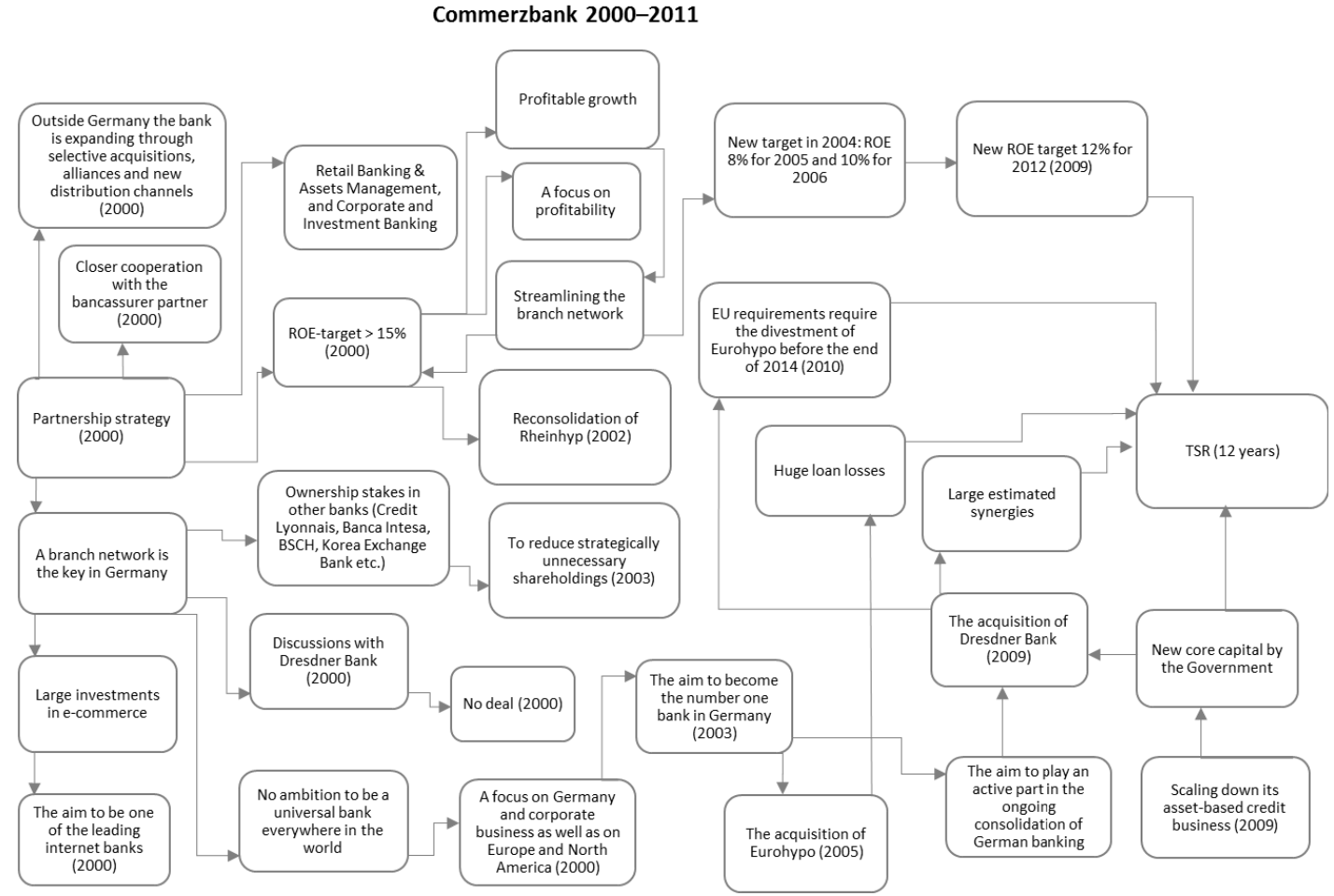

Figure 3: The Business Strategy Development of Commerzbank between 20002011.

During the studied period Commerzbank made significant changes in its business strategy and particularly it made these changes less by formulating its strategic core element gradually and more by making big changes all at one time. I identified five core elements in Commerzbank's organizational system in 2000. In early 2000 it was focusing on partnership strategy and it owned equity stakes in other large banks like Credit Lyonnais, Banca Intesa, Banco Santander Central Hispano, Korea Exchange, etc. (Commerzbank Annual Report 2000: 41, 45). This partnership strategy was one of the core elements in its business strategy. 
Another core element for Commerzbank was that its home market was in Germany where it had a wide branch network. The bank aimed to be the creative relationship bank for the successful German Mittelstand, for major corporates, and for institutions in Europe, as well as for multinationals from all over the world.

Other core elements for the bank were a focus on retail banking, improving profitability with the program "Commerzbank in the $21^{\text {st }}$ century," and a focus on internet banking through a separate subsidiary (Commerzbank Annual Report 2000: 4-5). Commerzbank aimed to explore new technologies through the subsidiary Commerz NetBusiness Ag, partnerships, and business models for the group. In 2000 Commerzbank had two months of merging negotiations with Dresdner Bank without a positive result.

Commerzbank's profitability was poor in 2001 and also in 2002 and 2003 it made losses. In 2002 the bank reduced its risk-weighted assets partly by securitizing risks and loans (Commerzbank Annual Report 2002: 4), and made write-downs on its electronic banking investments. Focusing on electronic banking was scaled down to a lower level, although the bank still had a strong focus on online brokering through its subsidiary bank Comdirect. It seems that a part of Commerzbank's strategy was to follow "fashion" trends in the banking market and to follow them although the bank did not have the right core competencies to be successful in these businesses. For example, this was the case with electronic banking in which the bank made huge investments in 2000 and some years later massive write-downs of these investments.

Another example of following "fashion" trends in the banking industry was that in 2002 Commerzbank decided to focus on private banking as a growth area and a core element of its business strategy (Commerzbank Annual Report 2002: 26). This was inconsistent with its prior focus because private banking has not traditionally been a core competence area for the bank. Later on they announced that in order to increase the quality of advice and customer satisfaction, they had added the investment funds of other institutions to their range, and already in 2003 half of their recommended investment funds were not produced by themselves (Commerzbank Annual Report $2003: 21$ ). This was again a good example of inconsistency in their business strategy. Commerzbank was on the one hand focusing on private banking 
and on the other hand they realized that they did not have enough quality in their investment advisory capabilities, and therefore they had to use "open architecture" and also sell third-party products.

In 2001 Commerzbank decided to step up the development of investment banking products for larger SMEs (Small- and medium-sized enterprises) and major corporates (Commerzbank Annual Report 2001: 38). Later on Commerzbank explored substantial investment banking activities (Ayadi et al., 2011), although investment banking business was far from the bank's earlier core competencies. Commerzbank's investment banking operations were very volatile; for example, in 2004 they realized that "geographically, the business line was too broadly positioned and its over-emphasis on on-customer proprietary trading meant that it was not sufficiently geared to customers' needs" Commerzbank Annual Report 2004: 34).

In 2005 Commerzbank, again, made another major change in the business strategy and decided to look for growth from the mortgage banking business and acquired an interest hold with Deutsche Bank and Allianz/Dresner Bank in Eurohypo by investing EUR 4.56 billion and strongly extended its scope to include the commercial real estate business (Commerzbank Annual Report 2005: 51, 53). The commercial real estate financing business was a growth business during this time and, after the acquisition, the Commerzbank Group become the German market leader in both commercial real-estate financing and private home loans as well as being market leader with Hypothekenbank (in Essen) in public-sector financing. Now the bank made a strategic change again and set the goal to be one of the five largest realestate banks in the USA as well (Commerzbank Annual Report 2005: 1).

In 2008 Commerzbank put more focus on customers, and it announced a two-phase acquisition of Dresdner Bank and, after the acquisition, Commerzbank become the leading bank in Germany for private and corporate customers. This move was inconsistent with its previous activities in that the acquisition Dresdner Bank led to a substantial jump in the bank's trading activities and in particular in derivative transactions, although some years earlier they announced that they would focus more on customers' needs in investment banking and much less on non-customer proprietary trading (Ayadi et al., 2011). During the global financial crisis, 
Commerzbank was recapitalized twice and the capital problems were mainly derived from huge losses on the non-customer proprietary trading portfolio acquired by the takeover of Dresdner Bank. In 2009 Commerzbank published a new strategy again with the target of becoming the leading principal bank in Germany (Commerzbank Annual Report 2009: 7).

All in all Commerzbank did not have consistency between its activities and the overall strategy over the studied period. The bank made many radical changes in its business strategy and it did not have a similar single strategic focus like Vanguard (Siggelkow, 2002). For example, when Vanguard aligned all activities with its lowcost strategy, Vanguard ensured that the competitive advantages of activities cumulate. Commerzbank's business strategy over the study period was very volatile and the bank developed its business strategy less by transforming the strategic core elements into a new form and more by making big changes all at one time.

Commerzbank's financial performance over the study period was very poor and its TSR was $-94.7 \%$ between 2000 and 2011 when the average TSR among the peer group was $-23.3 \%$ for the same period. Commerzbank's TSR was the worst among the studied 18 European major banks. My findings from the Commerzbank case suggest that low consistency in the business strategy of a bank leads to a negative impact on the value creation of the bank.

\section{RBS}

The second example is RBS. RBS has a very long history; the bank was founded in 1727 in Scotland. RBS opened its first branch outside Scotland in the City of London in 1874. During the 1980s RBS diversified its business, pioneering the direct distribution of motor insurance through the establishment of Direct Line in 1985. The first overseas representative office opened in New York in 1960 and the acquisition of Citizens Financial Group in 1988 established a major RBS presence in the US.

In the 1990s RBS re-engineered its retail banking business, removing processing activities from branches and segmenting the bank's customers and associated service propositions. Over the same period RBS developed and implemented its 
multi-brand, multiple channel strategy and launching both direct banking in 1994 and the UK's first internet banking service in 1997.

See the figure below (Figure 4) of RBS's business strategy development between 2000 and 2011.

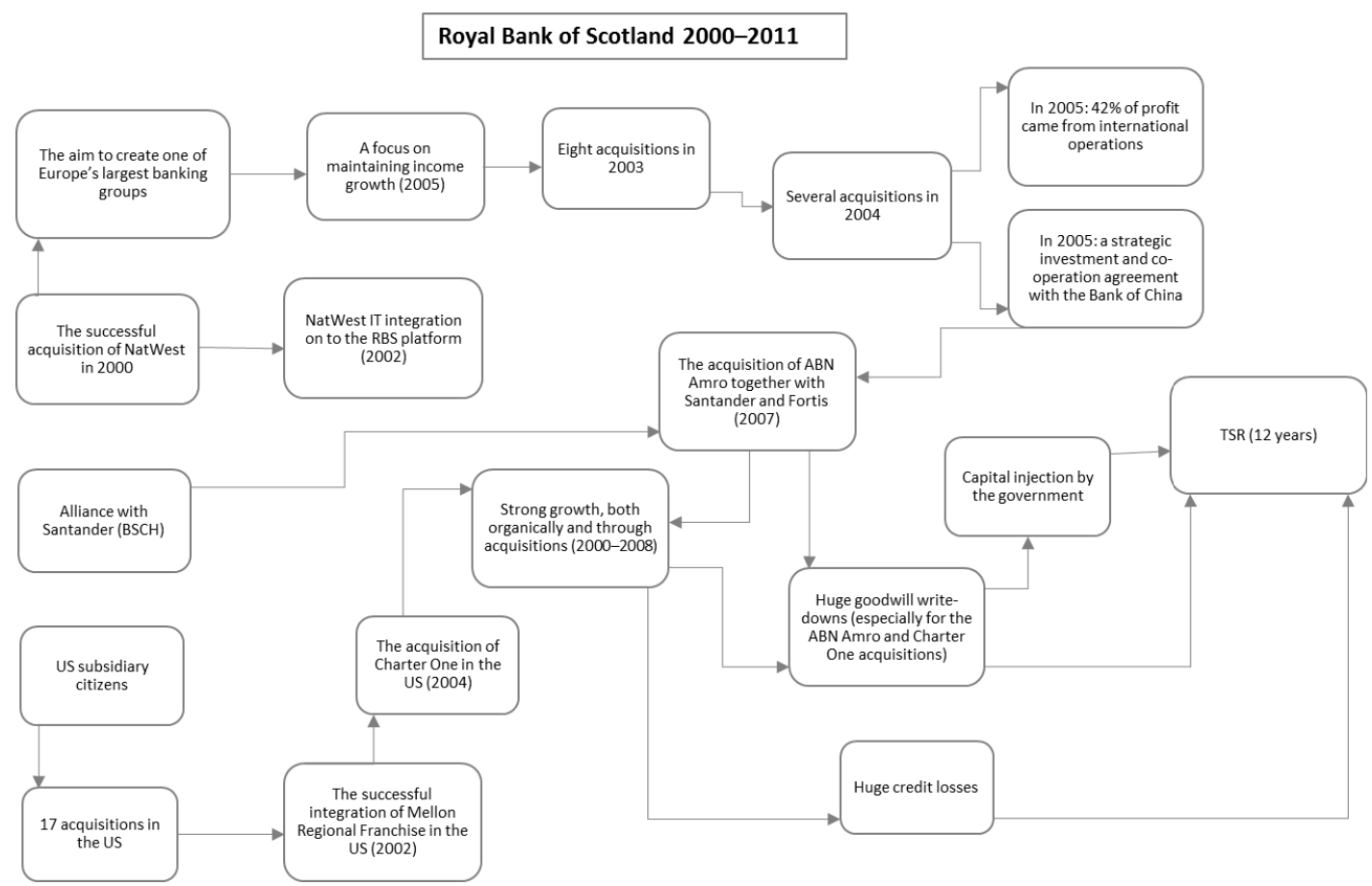

Figure 4: The Business Strategy Development of RBS between 2000-2011.

RBS acquired NatWest Bank for $£ 21$ billion in 2000, and the acquisition created the third largest banking group in the UK and one of Europe's largest banking groups with over 20 million customers, $£ 400$ billion in assets, and 110000 employees worldwide. This acquisition was the first stage in delivering the forecasted benefits to shareholders and customers, like the revenue gains and the cost savings through a single management structure, integrated support, and central services. Through the acquisition RBS combined NatWest's scale and presence with RBS's innovation and 
growth culture to create a new force in banking in the UK (RBS Group Annual Report 2000: 2).

After the NatWest transaction RBS decided to accelerate its growth strategy and create one of Europe's largest banking groups. During the 1990s capitalization of the RBS Group had increased from $£ 1.2$ billion to $£ 42.4$ billion and the top management of the bank had strong self-confidence when they set the new target to create one of the leading banks in Europe. The Chairman of RBS pointed out in the RBS Group's Annual Report 2000 that the bank had been the only UK bank to have been consistently successful in the US market (making 17 acquisitions), and that it had been the fastest growing bank in the UK (RBS Group Annual Report 2000: 2).

I identified four core elements in the bank's organizational system in 2000. The first core element was the rapid integration of the NatWest acquisition (RBS Group Annual Report 2000: 2). This acquisition enabled RBS to create one of Europe's largest banking groups and through this acquisition the bank targeted reaching remarkable revenue gains and cost savings. RBS revitalized the NatWest brand and put in place a single management structure throughout the enlarged group. The bank started the process of integrating support and central services to reduce costs. In 2002 a leading finance magazine, Business Week, wrote that "by consolidating technology platforms and making myriad other cost-cutting moves, RBS is expected to post the lowest cost-to-income ratio of any major European bank this year" (Business Week, 2002: 32).

In 2000 the second core element was the alliance strategy with Banco Santander Central Hispano (BSCH) (RBS Group Annual Report 2000: 2). The Chairman of the RBS Group, Viscount Younger of Leckie, pointed out in the Chairman's statement that the NatWest transaction could not have been possible without the support of $\mathrm{BSCH}$. He had been the Chairman of the group since January 1991 and stepped down from this position in December 2000.

The third core element was the multi-brand and multi-channel strategy (RBS Group Annual Report 2000: 2). RBS made banking business, for example in the US, under the brand name Citizens. The fourth core element was a focus on organic and non- 
organic growth with the main focus being outside the UK (RBS Group Annual Report 2000: 4). The group already had a leading position in the UK in corporate banking, retail banking, private banking, offshore banking, motor insurance, and supermarket banking.

In the following years RBS grew rapidly through acquisitions, many made in the US market. The Chairman of RBS Group, Sir George Mathewson, pointed out in his Chairman's statement in the RBS Group Annual Report 2003 that a key aspect of the group's strategy was building and retaining strategic options. As a result, the future progress of the group was not dependent on any particular economic scenario or market development. During 2004 RBS strengthened its activities outside the UK with several acquisitions.

In 2005, RBS signed strategic investment and co-operation agreements with the Bank of China, the second largest bank in China. To focus on an emerging market was a new core element in the business strategy of the group. RBS led a consortium that invested $\$ 3.1$ billion, taking a $10 \%$ stake in the Bank of China (RBS Annual Review 2005: 7).

RBS had a retail and corporate banking background, but it changed its strategy and put a lot of focus on investment banking and made a significant change in its business strategy. Notably, it made this change less by formulating its strategic core element gradually and more by making big changes all at one time. To build up a strong, global investment bank was a new core element in the business strategy of RBS. In 2007 a leading banking magazine, Institutional Investor, wrote that "Royal Bank of Scotland came from nowhere to build a powerful fixed-income franchise in Europe. Now it wants to go global" (Institutional Investor, March 2007: 42). The same magazine wrote that "RBS is all about leveraged finance."

The group's international investment banking activities grew fast in the years preceding the global financial crisis of 2008 due to numerous acquisitions, including the acquisitions of Charter One in the US (2004) and ABN AMRO (2007). The RBS Group's acquisition of ABN AMRO's wholesale and trading activities was the principal driver of the bank's transition from a traditional bank (in 2006) into an 
investment bank (during 2008 and 2009). The average total assets growth rate of RBS was $18.7 \%$ between 2000 and 2011 when the average total assets growth rate of the peer group was $11.8 \%$ for the same period. RBS grew too quickly and it had to take on more leveraging in its funding operations, and at the same time the risk profile of its credit portfolio become riskier. After the acquisition boom RBS could not integrate the acquisition targets rapidly enough into the group.

During the global financial crisis, RBS received massive liquidity and capital support from the UK government and the UK central bank. The main reason for the aid was that the bank had a high dependency on wholesale funding, as well as losses on structured assets (in investment banking) and higher credit risks generally (Ayadi et al., 2011). The RBS Group also made huge goodwill write-downs of acquisitions, for example, in 2008 these amounted to $£ 14.8$ billion. The TSR of RBS was $-90.1 \%$ between 2000 and 2011 and the average TSR among the peer group was $-23.3 \%$ for the same period.

At the end of study period (in 2011) RBS, again made major changes to its business strategy. Now the first core element of the business strategy in RBS was focusing on serving its customers well. After a strong focus on growth, in 2009, after the huge financial difficulties, the group decided to focus again on existing customers, not growth. The second core element was the reduction of risk positions and improving risk management. It meant reducing the group's balance sheet, risk and funding exposures through massive restructuring, and reducing both the scale and scope in areas where RBS was not naturally strong. The third core element was focusing on the bank's core businesses, back to basics. The fourth core element was to rebuild sustainable value for all shareholders, and then to enable the UK Government to sell its holding profitability over time (RBS Annual Review 2011: 10).

My conclusion is that RBS is a good example of a bank that made radical changes in its business strategy when it decided to accelerate its growth strategy and targeted becoming one of the largest banks in Europe, as well as a big player in investment banking globally. The bank tried to transform from a traditional retail bank into a universal bank with a strong investment banking arm. RBS did not have consistency between each activity and the overall strategy. My findings show that RBS developed 
its strategy less by gradually formulating its strategic core elements and more by making big changes all at one time. Thus the risk of organizational failure was at a higher level and this perception supports the conclusions of Amburgey et al. (1993).

The financial performance of RBS over the study period was very volatile and its TSR was $-90.1 \%$ between 2000 and 2011 , when the average TSR among the peer group was $-23.3 \%$ for the same period. The TSR of RBS was the second worst among the studied 18 major European banks. My results regarding the RBS case suggest that low consistency in the business strategy of a bank leads to a negative impact on the shareholder value creation of the bank.

\section{Standard Chartered}

The third example and one of the best performing banks, Standard Chartered Bank, was formed in 1969 through the merger of two separate banks, the Standard Bank of British South Africa and the Chartered Bank of India, Australia, and China. These banks capitalized on the expansion of trade between Europe, Asia, and Africa. The Chartered Bank was founded in 1853 and the bank opened its first branches in Mumbai (Bombay), Kolkata, Shanghai, Hong Kong, and Singapore between 1858 and 1859. Standard Bank was founded in London in 1862 (source: www.sc.com).

Today UK-based Standard Chartered is one of the world's most international banks with a global network in more than 130 countries. It has 150 years of emerging market experience and focuses on Asia, the Middle East, and Africa. In 2002 Standard Chartered employed 29000 people in over 500 offices in more than 50 countries, and in 2011 the bank employed 86900 people in 71 countries.

See the below figure (Figure 5) of Standard Chartered's business strategy development between 2000 and 2011. 


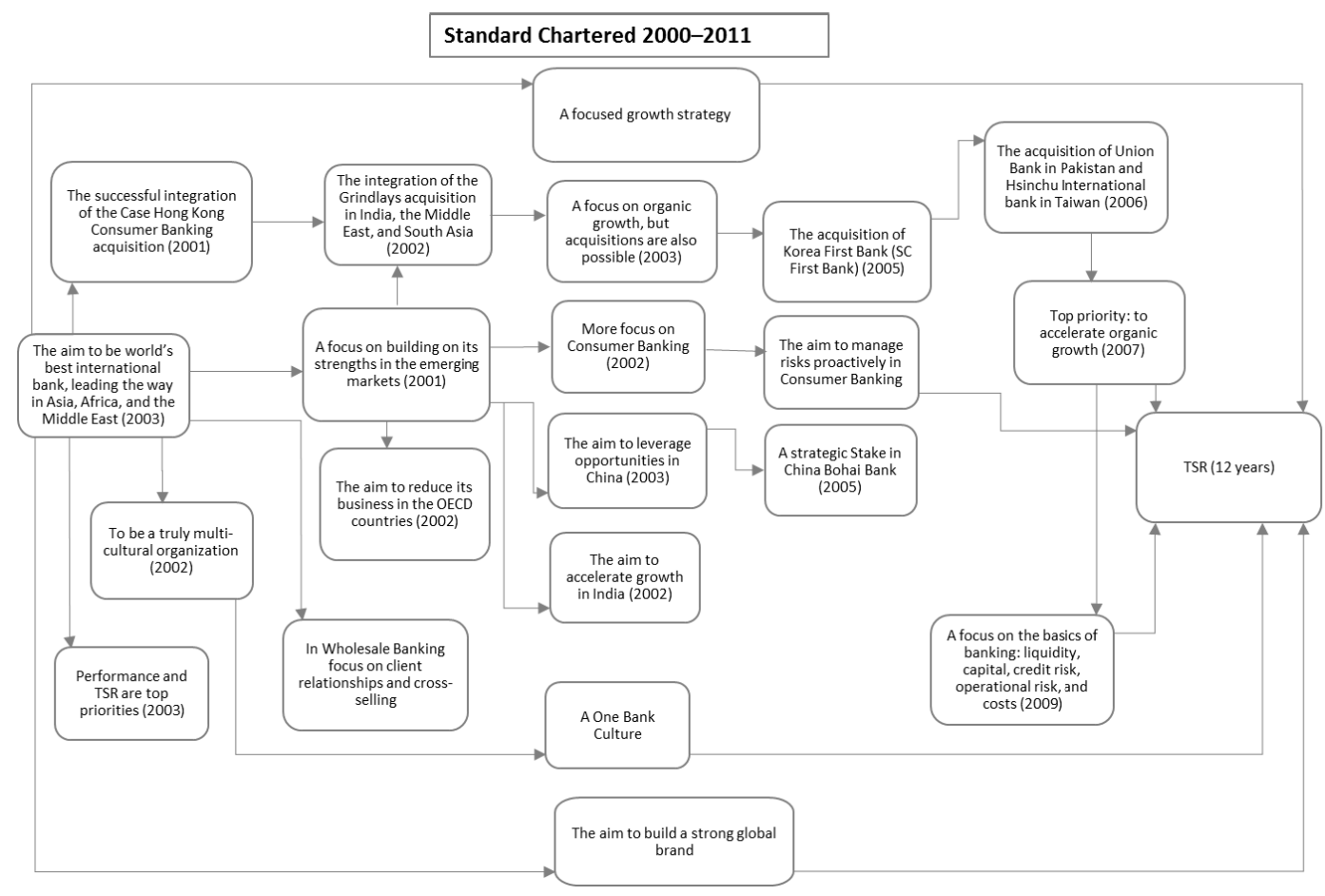

Figure 5: The Business Strategy Development of Standard Chartered Between 2000-2011.

Mervyn Davies, the Chief Executive of the bank from 2001 to 2006 and Chairman of the bank from 2006 to 2009, noted in 2006 that "Standard Chartered's strategic intent is to be the world's best international bank, leading the way in Asia, Africa and the Middle East. Through strong organic growth and disciplined acquisitions, the scale of Standard Chartered has been transformed in recent years" (The Banker, 2006: 52). Standard Chartered has had this aim over the study period. One of the core elements in the business strategy of Standard Chartered was a geographical focus on Asia, Africa, and the Middle East. This was already a core element in 2002, and was still in place at the end of the study period (in 2011) (e.g., Standard Chartered Annual Report 2002: 1; Standard Chartered Annual Report 2008: 4; Standard Chartered Annual Report 2011). 
The bank has kept a clear geographic focus on its key region while increasing its diversity to deliver consistent performance, and during the study period Standard Chartered formulated this strategic core element gradually and expanded its geographical focus into new countries inside these three areas. For example, in 2002 Standard Chartered operated in 50 different countries and in 2011 in 71 different countries.

The second core element for Standard Chartered was business focus on consumer banking and wholesale banking. The bank provides consumer banking services to individuals and small to medium-sized businesses, and offers wholesale banking capabilities to corporate and institutional clients. Standard Chartered has kept this strategic focus throughout the study period (e.g., Standard Chartered Annual Report 2002: 1; Standard Chartered Annual Report 2011).

The third core element was that Standard Chartered was run as one bank with two strong businesses (consumer banking and wholesale banking) that actively reinforce each other (e.g. Standard Chartered Annual Report 2008: 5; Standard Chartered Annual Report 2011). The bank had a clear strategic focus on the creation of a One Bank culture, building on a strong global brand, and growing in a sustainable way over the studied period.

Standard Chartered has aimed to be an international bank with truly multi-cultural organization and the fourth core element for the bank has been combining global capability and deep local knowledge. The bank's Chief Executive, Mervyn Davies, noted once that "an additional source of diversity for us is the range of nationalities and talents among our employees. We believe leading businesses will distinguish themselves through their international understanding and talented workforces" (The Banker, 2006: 52). This strategic pillar of scaling positions in significant local markets (combining global capabilities with local scale) has been a way to create a competitive edge for the bank and it has been a core element of the business strategy over the study period (e.g., Standard Chartered Annual Review 2005: 1; Standard Chartered Annual Report 2011). 
The fifth core element in the business strategy of Standard Chartered has been a focus on the basics of banking (liquidity, capital, credit risk, operational risk, and costs) (e.g., Standard Chartered Annual Report 2008: 9). This conservative and disciplined approach to risk, capital, and liquidity management has been an essential part of the business strategy of the bank over the study period.

The sixth core element for Standard Chartered has been a focus on organic growth. "Our plans are led by organic growth" Bryan Sanderson already pointed out in 2004 in his Chairman's Statement (Standard Chartered Annual Review 2003: 4). The bank has had this strategic pillar over the study period and where the bank cannot grow organically it is ready to explore acquisitions that reinforce the bank's core strategy (Standard Chartered Annual Report 2011).

All in all Standard Chartered has had good consistency between its activities and the overall strategy over the studied period. One example of this consistency in the business strategy of Standard Chartered is when Peter Sands, Group Chief Executive (2006-), pointed out in his review in 2009 that "we have a clear and consistent strategy which is well understood by customers, by staff, by regulators, by policymakers and by investors [...] We will keep the focus on basics of banking. We will stay open for business." (Standard Chartered Annual Report 2008: 10). " During the global financial crisis of 2008 Standard Chartered could keep its business focus on the basics of banking while many of its competitors were distracted by problems or were withdrawing to focus on their home market. Standard Chartered has had a clear business strategy and a conservative business model, and therefore the bank could better navigate through the global financial crisis than most of its competitors. Standard Chartered has had a very consistent strategy over the study period, and the bank developed its business strategy more by formulating its strategic core element gradually than by making big changes all at one time

Standard Chartered's financial performance over the study period was good and its TSR was the best among the studied 18 major European banks being $+158.1 \%$ for 2000 to 2011 when the average TSR among the peer group was $-23.3 \%$ for the same period. My results regarding the Standard Chartered case suggest that the best performers have better strategic fit in their business strategy and their business 
strategy is more consistent over time. Despite adapting to the changing markets, the successful banks are able to maintain fit between their activities.

\subsubsection{Phase 2: Selecting one of the best performers in the peer group in order analyze in more detail}

According to my results the best performers in the study group (assessed by TSR) from 2000 to 2011 were Standard Chartered $(+158.1 \%)$ and Nordea $(+114.1 \%)$, and the average TSR for the same period for all the studied banks was $-23.3 \%$ for the same period. .Next I decided to focus on one of the best performers with good strategic fit and analyze it in more detail. The argument selecting one of the best performers was that the best performers had a phenomenal capability to maintain a strategic fit and to shape their business strategies in a consistent way over the study period. Existing theory did not provide a satisfactory answer to the question of why and how some firms operating in the same industry, which underwent major changes, were able to maintain consistency and yet adapt, while others had to make more radical changes.

In my analysis, one of my initial research questions asked how fast a bank should grow. This question is fundamental to managerial practice but it is (and has been) difficult to answer. Banks need growth to remain vital and competitive, but growth also creates a number of managerial challenges. In some cases growing too quickly can lead to a crisis and even bankruptcy. Some scholars have developed a model of a "growth corridor" to determine how quickly a company can safely grow (Raisch \& von Krogh, 2007). The growth corridor is the path companies can take toward smart growth, which is set between their "minimum growth" and "maximum growth" rates. Some researchers have pointed out that growth is only beneficial up to a certain point, beyond which it destroys shareholder value (Penrose, 1959; Ramezani, Soenen, \& Jung, 2002). When I calculated a key performance indicator for the major European banks, I calculated a sustainable growth rate (SGR) and a competitive growth rate (CGR) for them. 
See Table 3 (The key performance indicators of the major European banks between 2000-2011).

Table 3: The key performance indicators of the major European banks between 2000-2011. See below the table for definitions of the terms.

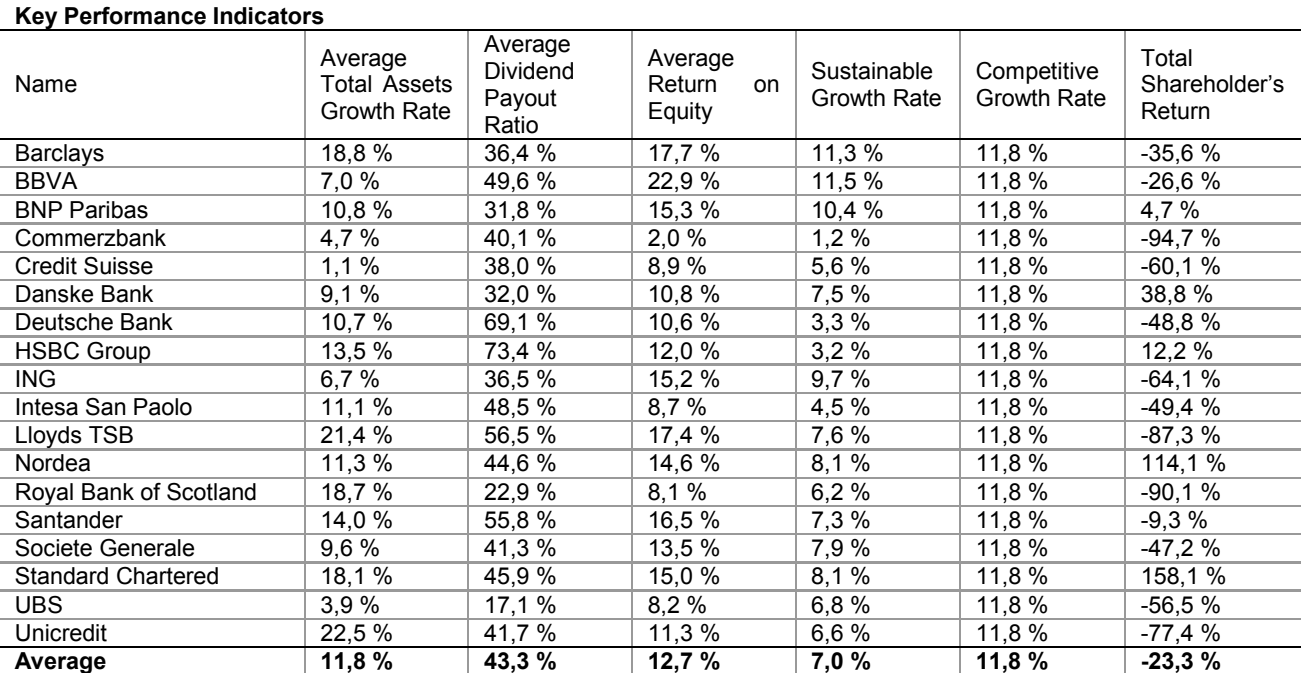

Average Total Assets Growth Rate = the average rate between 2000-2011. The rate is calculated as: total assets in year $n+1 /$ total assets in year $\mathrm{n} \times 100 \%$.

Average Dividend Payout Ratio = the average ratio between 2000-2011. The ratio is calculated as: yearly dividend per share / earnings per share.

Average Return on Equity $(\mathrm{ROE})=$ average ROE between 2000-2011. ROE is calculated as: net income / common shareholder's equity.

Sustainable Growth Rate = the maximum growth rate that a firm can sustain without having to increase financial leverage. Calculated as: ROE x (1 - dividend payout ratio).

Competitive Growth Rate = the average total assets growth rate in the peer group / industry for the period.

Total Shareholder Return $=$ the total return of stock to an investor (capital gains plus dividends). 
When I compared Standard Chartered and Nordea, both banks have had a very clear and focused business strategy over the study period and good strategic fit, but Nordea was also a new bank at the beginning of the study period (established by cross-border mergers between four Nordic banks). Further, richer and more versatile information about Nordea's business strategy was available (its annual reports and reviews, interim reports, CMD and conference presentations, and other IR material). It was also possible to interview some key people of Nordea's top management, who were Group Executive Management members or members of the Board of Directors in Nordea during the study period. I used these interviews to reinforce my observations and conclusions about the core elements and elaborating elements of Nordea's business strategy over the study period (2000-2011).

The reasons that I decided to select Nordea as a bank to analyze more carefully (in order to understand the developmental processes that lead to organizational configuration and fit) were that it had a good strategic fit in its business strategy, it was an interesting new bank created by cross-border mergers, there was good availability of rich and versatile information on its business strategy, and there was the possibility to interview key top management people who worked in the bank during the study period.

Next I focused more on Nordea's history and background, its business structure and organization functions, its financial performance between 2000 and 2011, and its business strategy for the same period.

\subsubsection{Nordea: A historical overview}

Nordea's history is long and its family tree includes some 300 banks, founded from the 1820s onwards. After that there have been many mergers and through them the number of banks decreased to 80 banks in the 1970s and 30 banks in the 1980s. In the 1990s there were four major banks in four different Nordic countries that decided to create the new banking group. These banks were Nordbanken in Sweden, Merita Bank in Finland, Unibank in Denmark, and Cristiania Bank og Kreditkasse in Norway. 
These four banks merged and all their operations have been conducted under the brand name of Nordea since December 2001. The new brand name came from combining the words "Nordic" and "idea", resulting in Nordea. A few years later Nordea's operations in Estonia, Latvia, Lithuania, Poland, and Russia reached a significant size, making Nordea an important bank in these countries also.

Today Nordea is the largest financial services group in the Nordic and Baltic Sea region. Nordea has 11 million customers and almost 1400 branch offices in nine home markets. Nordea is the leading bank in the Nordic countries and one of the major European banks.

Nordea's mission statement is "making it possible" and its vision is to be a great European bank, recognized for its people, creating superior value for customers and shareholders (source: www.Nordea.com).

\subsubsection{Nordea's business structure and organization}

Firstly it is necessary to understand how Nordea's business is organized at the beginning of the studied period.

In 2000 Nordea operated through six business areas: retail banking, corporate and institutional banking, asset management, investment banking, life insurance and pensions, and general insurance. The business areas operated as decentralized profit centers and the group's financial management operations were conducted by the group treasury (Nordea Annual Report 2000: 34).

The Nordea Group's total business relations with customers were reported in the customer-responsible unit's profit and loss account and balance sheet. Equity was allocated to the customer-responsible units, and each unit's performance was evaluated in relation to its individual target for return on allocated capital. The model for allocating capital takes into consideration credit and insurance risks, market risks, and operational risks. 
See the figure below (Figure 6: Nordea's Business Structure and Organization in January 2001).

\section{Business structure and organization}

January 2001

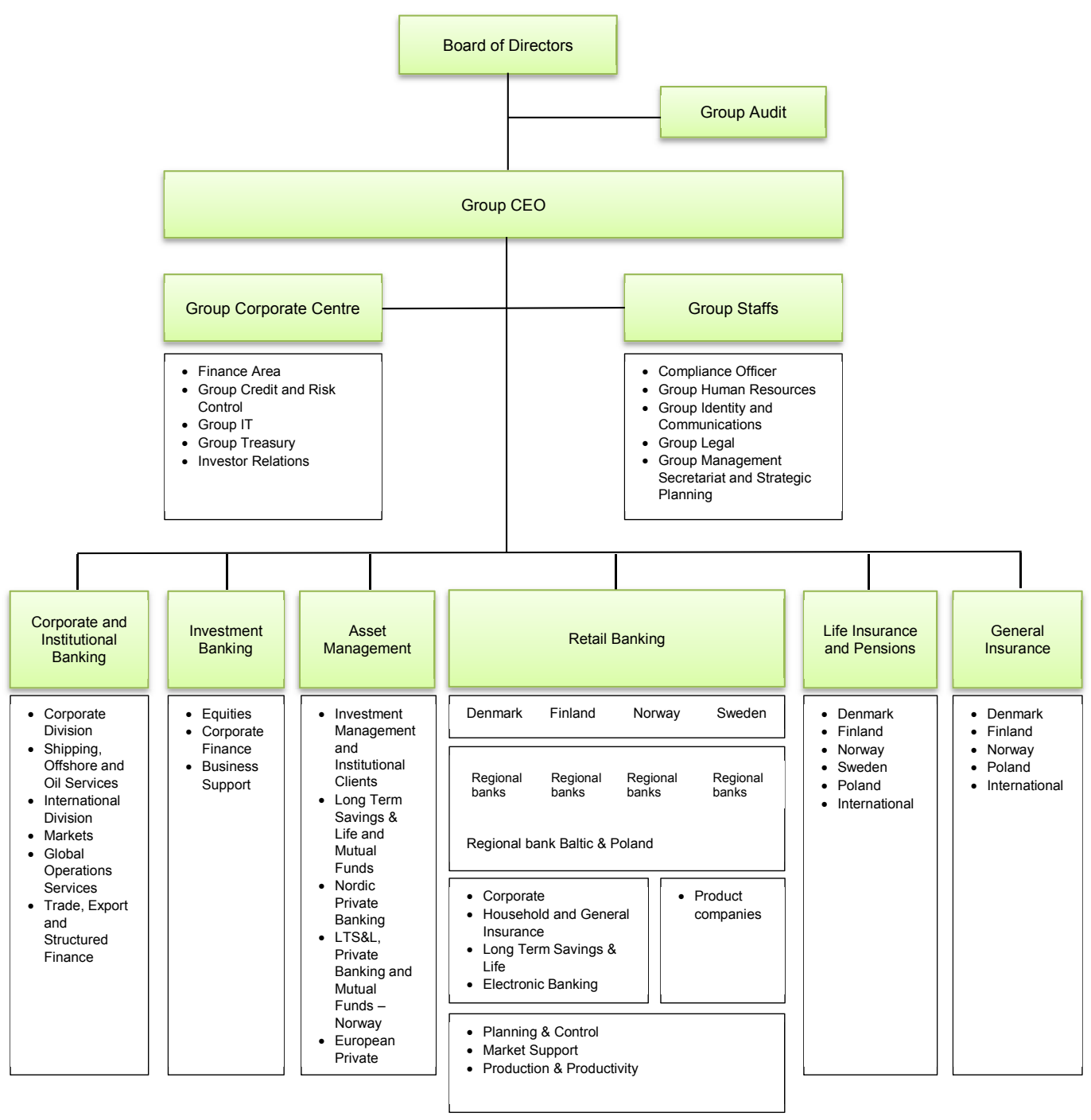

Figure 6: Nordea's Business Structure and Organization in January 2001 (Nordea Annual Report 2000: 36). 
Some business areas (BAs)—like asset management, investment banking, and life insurance and pensions-also had product responsibility, which means ensuring competitive and profitable products for the customer-responsible units. Product units were monitored through the evaluation of product results, which includes all income and expenses within the Nordea Group related to the respective products.

Capital was allocated to BAs of the bank reflecting the risks as well as the economic and strategic goals of the business.

\subsubsection{Nordea's financial performance between 2000-2011}

\section{Table 4: Nordea: Net Profit Between 2000-2011}

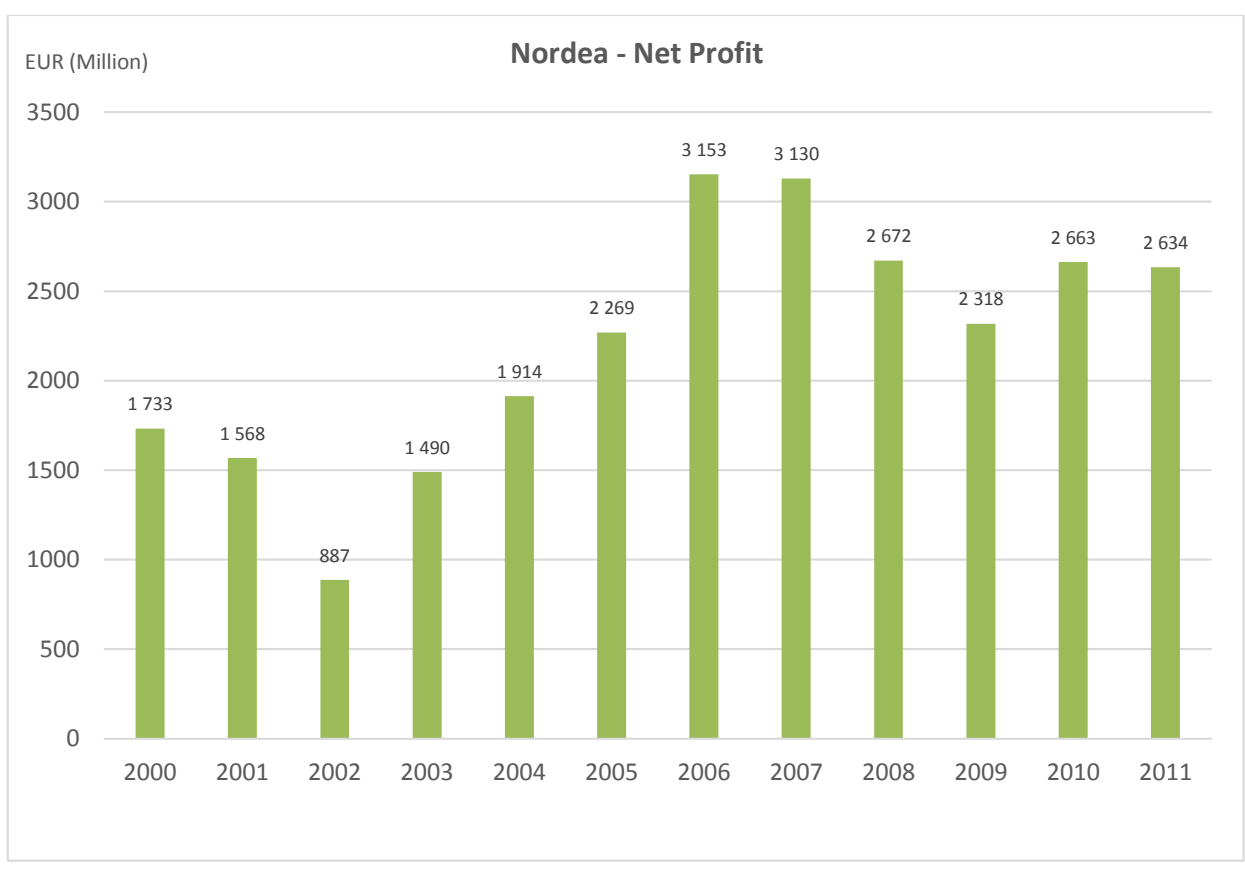

Nordea was a profitable company every year between 2000 and 2011. In 2000 its net profit $^{1}$ was EUR 1733 million and in 2011 it was EUR 2634 million. The lowest net profit in the period was EUR 887 million in 2002 and the highest was EUR 3153 million in 2006. Since 2008 Nordea's net profit has been pretty stable.

1) Net profit = operating profit after taxes 
Table 5: Nordea: ROE Between 2000-2011

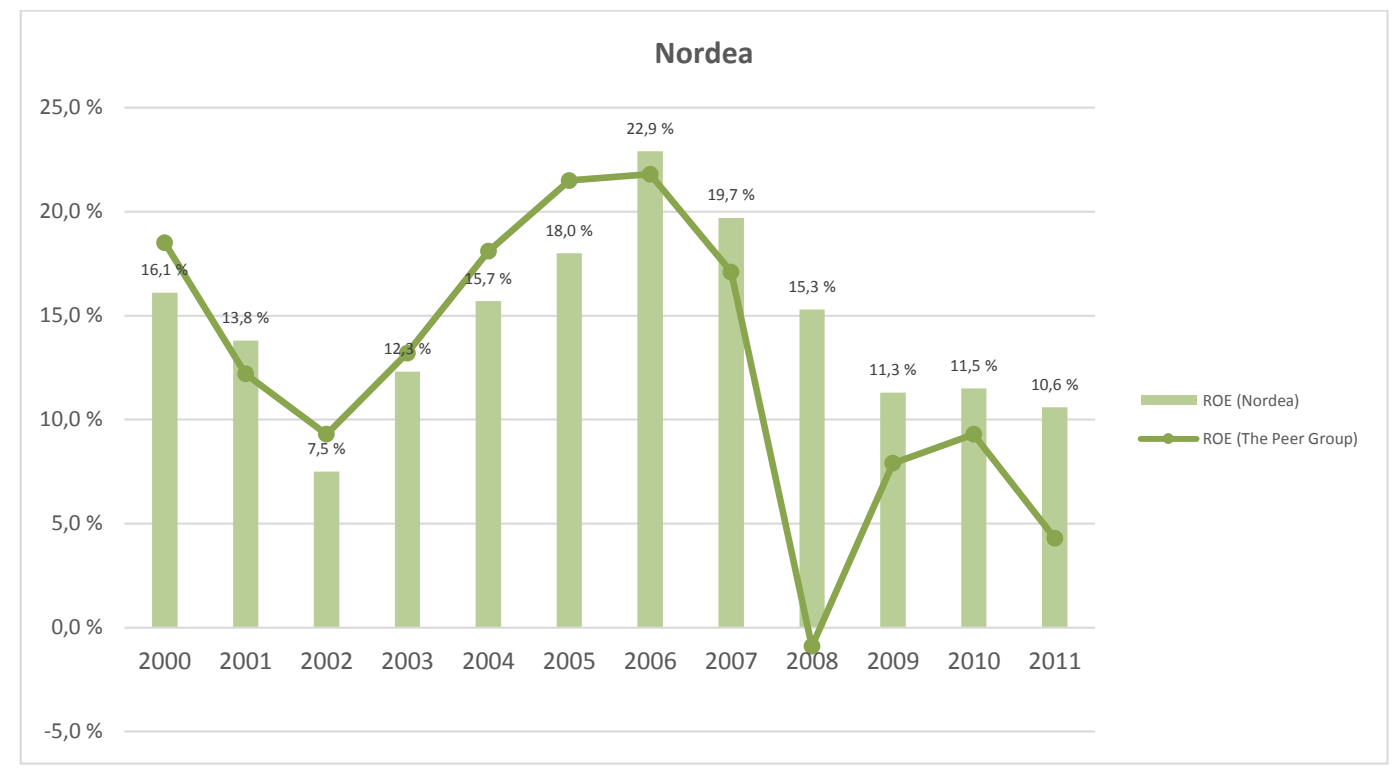

Nordea's average $\mathrm{ROE}^{2}$ between 2000 and 2011 was $14.6 \%$ and the average ROE for the peer group was $12.7 \%$ during the same period. It was a more profitable bank than its peers during the studied period.

Nordea's highest ROE was in 2006 when it was $22.9 \%$, which was on a higher than average level among its peers in the same year. The lowest ROE during the studied period was $7.5 \%$ in 2002. Although Nordea's ROE dropped especially in 2008 and 2009 , it was clearly on a higher level than the average level among its peers at the same time. From 2006 to 2011 Nordea's ROE was better than the average ROE among its peers.

In 2002 Nordea revised its key financial targets and set a new target that ROE should be $15 \%$ or more. Nordea reached this target and its ROE in 2004 was $15.7 \%$.

2) $\mathrm{ROE}=$ net income $/$ common shareholder's equity. 
In 2004 Nordea set new financial targets and one target was that ROE should be above $15 \%$ in 2005 and $17 \%$, or in line with the top Nordic peers, from 2007 onwards. Nordea reached its target in 2005, its ROE was 18.0\%. In 2006 its ROE was the highest ever at $22.9 \%$ and in 2007 it was also above the target level being $19.7 \%$.

After the global financial crisis in 2008, Nordea's ROE has been a level $10-11 \%$. In 2011 Nordea published its new ROE target of $15 \%$ in a normalized macroeconomic environment.

Table 6: Total Assets Growth Between 2000-2011.

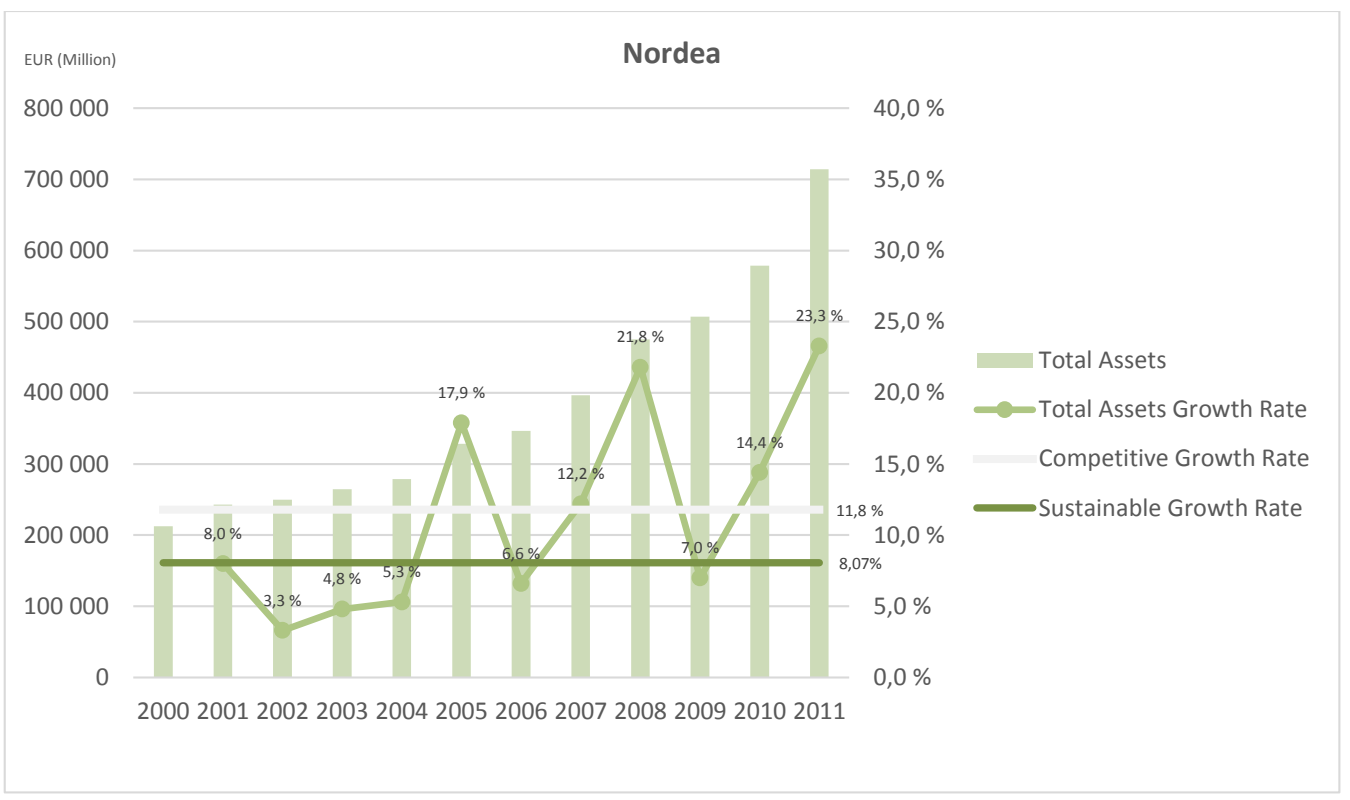

Nordea's average total assets growth rate ${ }^{3}$ between 2000 and 2011 was $11.3 \%$ and total assets growth rate for the peer group at the same time was $11.8 \%$.

3) Total assets growth rate $=$ total assets in year $n+1 /$ total assets in year $n \times 100 \%$. 
Nordea's total assets mostly grew in an organic way between 2000 and 2011 . The $\mathrm{SGR}^{4}$ for Nordea was $8.07 \%$ during the study period and the $\mathrm{CGR}^{5}$ for the same Period was $11.8 \%$. In 2011 Nordea's total assets were 3.5 times larger compared to the size of total assets in 2000 .

Table 7: Nordea: TSR between 2000-2011

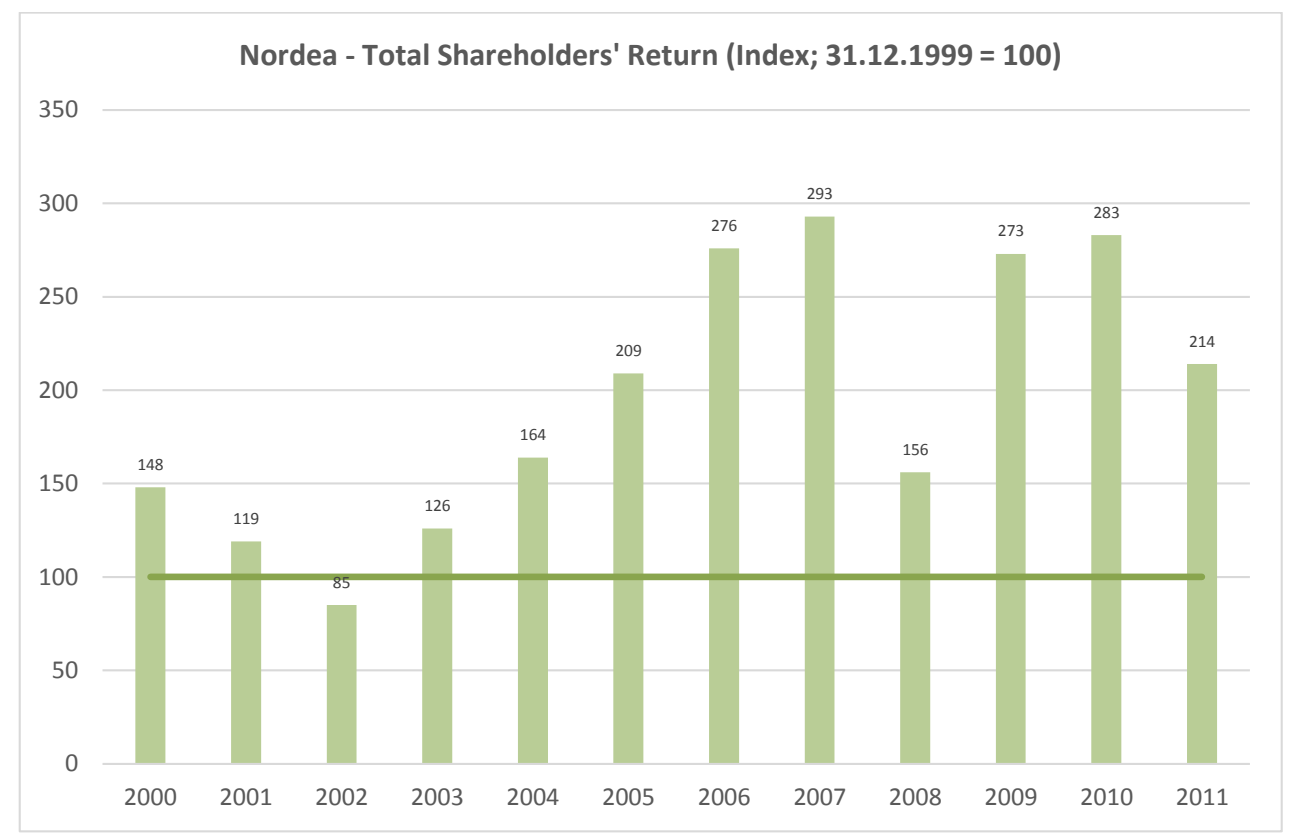

Nordea's TSR ${ }^{6}$ was $114.1 \%$ between 2000 and 2011 and the average TSR for the studied banks was $-23.3 \%$ for the same period (Credit Suisse, 2012).

Nordea's TSR developed very well from 2000 to 2007, when it was $191 \%$. During the global financial crisis of 2008 Nordea's TSR was clearly negative, but in 2009 and 2010 it developed again very well.

4) $S G R=$ the maximum growth rate that a firm can sustain without having to increase financial leverage. Calculated as: ROE $x$ (1 - dividend payout ratio).

5) $C G R=$ the average total assets growth rate in the peer group / industry for the period.

6) $\mathrm{TSR}=$ the total return of stock to an investor (capital gains plus dividends). 
Already in 2000 Nordea set a target to create value for the shareholders in line with the best listed financial service companies in Europe. In 2001 Nordea pointed out that its target is to create value for the shareholders, measured by TSR, and to be in the top five of its peer group of listed European financial service companies (20 selected companies).

In 2004 Nordea set new financial targets and one of them was that TSR should be in the top quartile of the European peer group and this target remained unchanged from 2004 to 2011.

\subsubsection{Nordea's business strategy between 2000-2011}

The background for Nordea was that the merging partners forming the bank shared the vision of becoming the leading financial services group in the Nordic and Baltic Sea region. The business rationale for a Nordic financial services group was the rapid integration of Nordic business and the fact that people in Nordic countries are similar, sharing Nordic values such as freedom, modernism, and care for the environment and following the Nordic heritage of breaking new ground (Nordea Annual Report 2000: 6).

Nordea is the result of mergers and acquisitions of the Swedish, Finnish, Danish, and Norwegian banks of Nordbanken, Merita Bank, Unibank, and Kreditkassen (Christiana Bank). Nordbanken and Merita Bank merged in 1997 and the new name of the bank was MeritaNordbanken.

The next step in the Nordic integration process was that at the beginning of March 2000, the merger between MeritaNordbanken and Unidanmark was announced (Unidanmark itself was formed by a merger in 1999 between Danish Unibank and Tryg-Baltica). The merger was the decisive step in the formation of the Nordic financial group (Nordea Annual Report 2000: 6).

Efforts to create the leading Nordic financial services group continued in 2000 by including Kreditkassen (Christiana Bank) in the Nordea Group (Nordea Annual Report 2000: 7). 
Following the formation of Nordea in 2000, the bank had a strong focus on the harmonization of the operations, efficiency, and performance. The period between 2000-2001 was named Group Formation (Nordea Annual Report 2010: 8).

At the end of year 2000 Nordea was the leading financial services group in the Nordic and Baltic Sea region and operated through six business areas: retail banking, corporate and institutional banking, asset management, investment banking, life insurance and pensions, and general insurance. The group had nearly 10 million customers and 1260 bank branches in 22 countries. Nordea had a lot of focus on internet banking and in 2000 the bank was a world leader in internet banking, with more than 2.2 million e-customers (Nordea Annual Report 2000: 1).

In 2000 Nordea set the target to be one of leading listed financial service companies in Europe in terms of growth in earnings per share and ROE.

According to Nordea's vision it wanted to be valued as the leading financial services group in the Nordic and Baltic financial markets with substantial growth potential. Nordea's ambition was that it should be number one or number two, with show superior and profitable growth in every market and product area in which they choose to compete. It planned to have the leading multichannel distribution with a top world ranking in e-based financial solutions. Nordea planned to operate as an integrated Nordic group in focused business areas, and to create value for shareholders in line with the best among the European listed financial services groups (Nordea Annual Report 2000: 3).

According to Hans Dahlborg-President and CEO in 2000, Vice Chairman of the Board in 2001, and Chairman of the Board from 2002 to 2010—while establishing the banking and insurance market structure in the Nordic home market, Nordea continued to build its positions in its emerging home market of Poland and the Baltic states. Nordea planned to coordinate and integrate products and distribution channels (Nordea Annual Report 2000: 7).

Hans Dahlborg said that Nordea was dedicated to delivering financial solutions in partnership with customers (Nordea Annual Report 2000: 7). He pointed out that the 
broader the product portfolio, the competence, and the investment base is, the more products they can exchange and the better products and services they can develop.

Thorleif Krarup_President and CEO from 2001 to2002-pointed out that Nordea is an integrated Nordic group, not a federation or an alliance of national banks and insurance companies. Reporting lines, accounting and control, group staff, branding, and an emerging common culture all support this structure. He also pointed out that the e-revolution would fundamentally change the financial services industry forever. This would become increasingly evident in productivity, new products and services, everyday e-services that empower the customer, lower barriers for new competitors to enter into the business, and increased opportunities for customers to change their bank and insurance company (Nordea Annual Report 2000: 10-11).

One board member of Nordea said that Nordea's business strategy was reviewed every year at board level, and the basic element for the strategy was to create a Nordic bank that had full network coverage in the Nordic countries (board member's interview, 2014).

Nordea's key financial target in $\mathbf{2 0 0 0}$ was to create value for shareholders in line with the best European listed financial services companies. "Value for shareholders" includes market value and dividends (Nordea Annual Report 2000: 22).

In 2001 and early 2002 Nordea negotiated a merger with the Dutch banking giant ABN AMRO. The Dutch bank was of particular interest to Nordea as it had the most operations in the Nordic region of all the large European banks. Since 1995 ABN AMRO had owned a leading Nordic asset manager and investment bank, Alfred Berg, and it had earlier announced that it was looking for a new partner. During this time ABN AMRO had activities in 75 countries-including the US, Malaysia, and Brazil-and the bank was nearly double the size of Nordea (Helsingin Sanomat, 2002).

Many members of the top management at Nordea supported the merger (board member's interview, 2014; top managers, 2014, 2015), but the forthcoming Chairman, Hans Dahlborg (President and CEO in 2000, Vice Chairman of the Board 
in 2001, and Chairman of the Board between 2002-2010), was deeply skeptical about the deal, because Nordea was itself just in the integration process after many mergers over the last few years. Dahlborg also pointed out that ABN AMRO had businesses all over the world (e.g. in Brazil) and therefore its business portfolio was totally different from Nordea's business portfolio. ABN AMRO's key financial figures were not calculable and its cost structure was too heavy. In February 2002 Nordea's Board of Directors decided to close the negotiations with ABN AMRO without any deal (Dahlborg, 2014).

The period from 2002 to 2006 was a time for stability and profitability. To enhance stability and profitability, several initiatives under the banner of focus, speed, and performance were conducted during the years 2002 to 2006 (Nordea Annual Report 2010: 8).

Lars G. Nordström, President and CEO from 2002 to 2006, launched three internal keywords to highlight the need for improvements and changes in the organization: focus, speed, and performance. Focus meant concentrating on Nordea's strengths and closing down or divesting businesses and activities that were not core business, were underperforming or were not profitable. Speed meant being quick and flexible, having smooth and efficient operations, and always adjusting to market conditions. Performance meant increasing performance orientation and continuous improvements in all work. "Do better today than yesterday." "Be better than the competitors" (Nordea Annual Report 2002: 7).

The period from 2007 to 2008 was a time of profitable organic growth (Nordea Annual Report 2010: 8). Christian Clausen, President and CEO since 2007, pointed out in his first letter to shareholders (in 2007) that it was time to take the next step forward and form a great Nordea. He wrote that a great company would be characterized by four elements: a strong profit orientation, an ambitious vision and ambitious targets, a clear growth strategy, and strong customer-oriented culture and values (Nordea Annual Report 2007: 4).

The period from 2010 to 2011 was a period of prudent growth. During this period Nordea launched nine group-level initiatives for growth, efficiency, and improving 
foundations (Nordea Annual Report 2010: 8-9). The bank's vision was to become a great European bank, acknowledged for its people, creating superior value for its customers and shareholders (Nordea Annual Report 2011: 11). In 2011 Nordea replaced its previous profitability target with a new target: to reach an ROE of $15 \%$ in a normalized macroeconomic environment and at an 11\% core Tier 1 capital ratio (Nordea Annual Report 2011: 4).

See below (Table 8) for Nordea's published key financial targets between 2000 and 2011. 
Table 8: Nordea's Key Financial Targets from 2000 to 2011

\begin{tabular}{|c|c|c|c|c|c|c|}
\hline YEAR & 2000 & 2001 & 2002 & 2003 & 2004 & 2005 \\
\hline $\begin{array}{l}\text { KEY } \\
\text { FINANCIAL } \\
\text { TARGETS }\end{array}$ & $\begin{array}{l}\text { - To be number one or } \\
\text { number two, and } \\
\text { show superior and } \\
\text { profitable growth in } \\
\text { every market and } \\
\text { product area in } \\
\text { which Nordea } \\
\text { chooses to compete } \\
\text { - To create value for } \\
\text { the shareholders in } \\
\text { line with the best } \\
\text { listed financial } \\
\text { service companies in } \\
\text { Europe } \\
\text { - To be one of the } \\
\text { leading listed } \\
\text { financial service } \\
\text { companies in Europe } \\
\text { in terms of growth in } \\
\text { earnings per share } \\
\text { and return on equity } \\
\text { (ROE) } \\
\text { - ROE } \geq \text { the euro risk- } \\
\text { free interest rate }+8 \\
\% \text {-points } \\
\text { - Cost/income ratio in } \\
\text { banking } \leq 50 \% \\
\text { - Dividend payout } \\
\text { ratio } \geq 40 \% \text { of net } \\
\text { profit } \\
\text { - Tier } 1 \text { capital ratio } \geq \\
6.5 \%\end{array}$ & $\begin{array}{l}\text { - To be number one or } \\
\text { number two, and } \\
\text { show superior and } \\
\text { profitable growth in } \\
\text { every market and } \\
\text { product area in } \\
\text { which Nordea } \\
\text { chooses to compete } \\
\text { - To create value for } \\
\text { the shareholders, } \\
\text { measured by total } \\
\text { shareholder return } \\
\text { (TSR), and be in the } \\
\text { top } 5 \text { of the peer } \\
\text { group of listed } \\
\text { European financial } \\
\text { service companies } \\
\text { (20 selected } \\
\text { companies) } \\
\text { - ROE } \geq \text { the euro risk- } \\
\text { free interest rate }+8 \\
\% \text {-points } \\
\text { - Cost/income ratio in } \\
\text { banking } \leq 50 \% \\
\text { - Dividend payout } \\
\text { ratio } \geq 40 \% \text { of net } \\
\text { profit } \\
\text { - Tier } 1 \text { capital ratio > } \\
6.5 \%\end{array}$ & $\begin{array}{l}\text { - To create value for } \\
\text { the shareholders, } \\
\text { measured by TSR, } \\
\text { and be in the top } 5 \\
\text { of the peer group of } \\
\text { listed European } \\
\text { financial service } \\
\text { companies (20 } \\
\text { selected companies) } \\
\text { - Revised key financial } \\
\text { targets: } \\
\text { o ROE } \geq 15 \% \text { from } \\
2004 \\
\text { Costs at the same } \\
\text { level through } 2004 \\
\text { as in } 2002 \\
\text { A cost/income } \\
\text { ratio of } 55 \% \text { by } \\
2005 \text { with the } \\
\text { present business } \\
\text { mix } \\
\text { - All other targets } \\
\text { remain unchanged }\end{array}$ & $\begin{array}{l}\text { - To create value for } \\
\text { the shareholders, } \\
\text { measured by TSR, } \\
\text { and be in the top } 5 \\
\text { of the peer group of } \\
\text { listed European } \\
\text { financial service } \\
\text { companies (20 } \\
\text { selected companies) } \\
\text { - Unchanged key } \\
\text { financial targets: } \\
\text { o ROE } \geq 15 \% \text { from } \\
2004 \\
\text { Costs at the same } \\
\text { level through } 2004 \\
\text { as in } 2003 \\
\text { - A cost/income } \\
\text { ratio of } 55 \% \text { by } \\
2005 \text { with the } \\
\text { present business } \\
\text { mix } \\
\text { - All other targets } \\
\text { remain unchanged }\end{array}$ & $\begin{array}{l}\text { - New financial } \\
\text { targets: } \\
\circ \text { TSR in the top } \\
\text { quartile of the } \\
\text { European peer } \\
\text { group } \\
\circ \text { ROE above } 15 \% \text { in } \\
2005 \text { and } 17 \% \text { or } \\
\text { in line with the top } \\
\text { Nordic peers from } \\
2007 \text { onwards } \\
\circ \text { Costs unchanged } \\
\text { from } 2004 \text { through } \\
2007 \\
\circ \text { Continuous } \\
\text { improvement of } \\
\text { the cost/income } \\
\text { ratio }\end{array}$ & $\begin{array}{l}\text { - Unchanged key } \\
\text { financial targets: } \\
\text { O TSR in the top } \\
\text { quartile of the } \\
\text { European peer } \\
\text { group } \\
\text { O ROE above } 15 \% \text { in } \\
2005 \text { and } 17 \% \text { or } \\
\text { in line with the top } \\
\text { Nordic peers from } \\
2007 \text { onwards } \\
\text { Costs unchanged } \\
\text { from } 2004 \text { through } \\
2007\end{array}$ \\
\hline EVIDENCES & $\begin{array}{l}\text { Nordea Annual Report } \\
2000 \text {, pages } 3,22 \text { and } \\
23 \text {. }\end{array}$ & $\begin{array}{l}\text { Nordea Annual Report } \\
2001 \text {, pages } 4 \text { and } 24 \text {. }\end{array}$ & $\begin{array}{l}\text { Nordea Annual Review } \\
2002 \text {, pages } 10 \text { and } 26\end{array}$ & $\begin{array}{l}\text { Nordea Annual Review } \\
2003 \text {, pages } 18 \text { and } 20 .\end{array}$ & $\begin{array}{l}\text { Nordea Annual Review } \\
\text { 2004, page } 6 .\end{array}$ & $\begin{array}{l}\text { Nordea Annual Report } \\
\text { 2005, page } 13 .\end{array}$ \\
\hline YEAR & 2006 & 2007 & 2008 & 2009 & 2010 & 2011 \\
\hline $\begin{array}{l}\text { KEY } \\
\text { FINANCIAL } \\
\text { TARGETS }\end{array}$ & $\begin{array}{l}\text { - New financial } \\
\text { targets: } \\
\text { ○ TSR in the top } \\
\text { quartile of the } \\
\text { Nordic peer group } \\
\text { and European } \\
\text { financial services } \\
\text { companies } \\
\text { o To double the } \\
\text { bank's risk- } \\
\text { adjusted profit in } \\
7 \text { years (from } 2006 \\
\text { to } 2013 \text { ), which } \\
\text { implies an annual } \\
\text { average growth } \\
\text { rate of } 10 \% \\
\text { - ROE in line with } \\
\text { the top Nordic } \\
\text { peers from } 2007 \\
\text { onwards } \\
\text { Tier } 1 \text { capital ratio } \\
\text { above } 6.5 \%\end{array}$ & $\begin{array}{l}\text { - The key financial } \\
\text { targets are } \\
\text { unchanged: } \\
\text { TSR in the top } \\
\text { quartile of the } \\
\text { Nordic peer group } \\
\text { and European } \\
\text { financial services } \\
\text { companies } \\
\text { - ROE in line with } \\
\text { the top Nordic } \\
\text { peers from } 2007 \\
\text { onwards } \\
\text { To double the } \\
\text { bank's risk- } \\
\text { adjusted profit in } \\
7 \text { years (from } 2006 \\
\text { to } 2013 \text { ), which } \\
\text { implies an annual } \\
\text { average growth } \\
\text { rate of } 10 \%\end{array}$ & $\begin{array}{l}\text { - The key financial } \\
\text { targets are } \\
\text { unchanged: } \\
\text { o TSR in the top } \\
\text { quartile of the } \\
\text { Nordic peer group } \\
\text { and European } \\
\text { financial services } \\
\text { companies } \\
\text { - ROE in line with } \\
\text { the top Nordic } \\
\text { peers } \\
\text { O To double the } \\
\text { Bank's risk- } \\
\text { adjusted profit in } \\
7 \text { years (from } 2006 \\
\text { to } 2013 \text { ), which } \\
\text { implies an annual } \\
\text { average growth } \\
\text { rate of 10\% }\end{array}$ & $\begin{array}{l}\text { The key financial } \\
\text { targets are } \\
\text { unchanged: } \\
\text { O TSR in the top } \\
\text { quartile of the } \\
\text { Nordic peer group } \\
\text { and European } \\
\text { financial services } \\
\text { companies } \\
\text { O ROE in line with } \\
\text { the top Nordic } \\
\text { peers } \\
\text { O To double risk- } \\
\text { adjusted profit in } \\
7 \text { years (from } 2006 \\
\text { to } 2013 \text { ), which } \\
\text { implies an annual } \\
\text { average growth } \\
\text { rate of } 10 \%\end{array}$ & $\begin{array}{l}\text { - The key financial } \\
\text { targets are } \\
\text { unchanged: } \\
\text { O TSR in the top } \\
\text { quartile of the } \\
\text { Nordic peer group } \\
\text { and European } \\
\text { financial services } \\
\text { companies } \\
\text { - ROE in line with } \\
\text { the top Nordic } \\
\text { peers } \\
\text { To double risk- } \\
\text { adjusted profit in } \\
7 \text { years (from } 2006 \\
\text { to } 2013 \text { ), which } \\
\text { implies an annual } \\
\text { average growth } \\
\text { rate of } 10 \%\end{array}$ & $\begin{array}{l}\text { The previous } \\
\text { financial targets } \\
\text { have been replaced } \\
\text { with one: ROE } 15 \% \\
\text { in a normalized } \\
\text { macroeconomic } \\
\text { environment, and at } \\
\text { an } 11 \% \text { core Tier I } \\
\text { capital ratio }\end{array}$ \\
\hline EVIDEI & $\begin{array}{l}\text { Nordea Annual Report } \\
\text { 2006, pages } 3 \text { and } 16 .\end{array}$ & $\begin{array}{l}\text { Nordea Annual Report } \\
2007 \text {, pages } 12-13 \text {. }\end{array}$ & $\begin{array}{l}\text { Nordea Annual Report } \\
\text { 2008, page } 8 .\end{array}$ & $\begin{array}{l}\text { Nordea Annual Report } \\
\text { 2009, page } 8 \text {. }\end{array}$ & $\begin{array}{l}\text { Nordea Annual Report } \\
\text { 2010, page } 16 .\end{array}$ & $\begin{array}{l}\text { Nordea Annual Report } \\
2011 \text {, pages } 8 \text { and } 11 .\end{array}$ \\
\hline
\end{tabular}




\subsubsection{Phase 3: Analyzing and describing more detailed organizational-system maps for Nordea}

In the third phase of my data analysis, I analyzed and described in more detail organizational-system maps, compromising the elements and interactions of Nordea in every year between 2000 and 2011. Studying the underlying processes of organizational development requires a research setting that allowed an analysis of an organizational system, compromising elements and interactions at various points in time (Siggelkow, 2002).

The leading Nordic bank, Nordea, was one of the most successful banks of my sample during the studied period. In my study I focused on analyzing and detailing Nordea's activity system between 2000 and 2011 more carefully in order to understand which organizational elements have been more central or core to Nordea. I tried to also understand the nature of the core elements and underlying developmental processes that led to configurations. I used a theory-elaborating approach when I engaged a study of the developmental path of Nordea. To identify the core elements, the notion of interactions among the elements of an organizational system played a key role.

To better understand Nordea's organizational system, I mapped Nordea's organizational system for every year from 2000 to 2011. The organizational-system maps show how Nordea's strategic position is contained in a set of tailored activities designed to deliver it. I used those organizational-system maps to examine strategic fit in the business strategy of Nordea.

To map out Nordea's operational systems, I used a longitudinal case-study design (Eisenhardt, 1989). Three methods were used for collecting data: (1) archival data, including electronic, printed, and written material, (2) interviews, and (3) secondary data, including previous studies and reports on Nordea. I especially used interviews to validate and enrich my observations and conclusions about the core elements and elaborating elements of Nordea's business strategy over the study period (20002011). My informants were highly knowledgeable and they viewed the focal phenomena from diverse perspectives. I was not studying the perceptions of various 
individuals (as is sometimes done in qualitative research)—the informants provided corroborating evidence of the existence of specific organizational elements, about which it was best to rely on this small number of selected, highly knowledgeable informants.

My database of a large variety of variables was compiled in order to get a picture of Nordea's business strategy and business model, total asset growth, profitability, and TSR. The compilation exercise relied mostly on publicly available data obtained from Nordea's annual reports and reviews, interim reports, CMD and conference presentations, and other IR material. These issues and their implications were evaluated longitudinally.

Archival and secondary data from the period 2000 to 2011 was collected for the case study. The rich and versatile set of archival data included all the relevant company material from Nordea relevant to my study and research question. Nordea is a listed bank, whose shares are listed on the Stockholm Stock Exchange and whose reports are public information; therefore, the transparency of the bank is at a high level. There were different sources of secondary data such as financial and banking journal articles, investment analyses by investment banks, and TSR statistics for Nordea provided by investment banks.

The data sources were the published annual reports and reviews, interim reports, CMD and conference presentations, and other public IR material of Nordea. In my data analysis I went through all this above-mentioned financial information on a yearby-year basis. There were 12 annual reports in total, with 200 pages per annual report on average (totalling 2400 pages) and 48 interim reports. My data then gives a 12-bank-year observation of Nordea. I use a wide range of performance and other indicators related to the financial activity and financial performance of Nordea. My data also included 119 articles on Nordea from the leading global banking magazine The Banker. I have used 225 citations of Nordea's business strategy in my analysis and these quotes are coded to the organizational maps of Nordea. All these citations are published Nordea's annual reports, annual reviews, interim reports, or CMD or conference presentations. 


\subsubsection{Phase 4: Interviews to validate and enrich my perceptions}

To validate and enrich my observations of Nordea and its activity system, I conducted three interviews with Nordea's past board members and top managers (see Table 9: INTERVIEWS). The interviewees were theoretically sampled in order to have the informants most likely to have relevant knowledge. I conducted three interviews because this was a sufficient number for verifying the existing of the organizational elements and their relationships.

I chose to interview Timo Peltola because he has been as board member of Nordea in from 1998 to 2010, in other words for almost the whole study period (2000-2011). He was also the Vice Chairman of the Board from 2002 to 2008. Hans Dahlborg is another person who had an equally long history as a board member of Nordea. I used Hans Dahlborg's biography "Ansvarets skönä börda - Mina år med Nordea” as a source in my study (Dahlborg, 2014).

I chose to interview Carl-Johan Granvik and Markku Pohjola because both of them were long-standing members of the Management Board at Nordea. Carl-Johan Granvik was on the board from 2000 to 2010 and Markku Pohjola from 2000 to 2008.

In total the interviewees had 28 years of experience of Nordea, either on the board or at top management level, and the study period was 12 years (2000-2011). Because my aim was to better understand how Nordea developed and maintained fit between organizational elements, it was important and necessary that the interviewees had been in high organizational positions at Nordea for as long as possible during the study period. To be as a member of the Group Executive Management or a member of the Board of Directors is to be in a position in which a person is really involved in the strategy process of the bank. Therefore these persons were the most relevant persons to interview for this study.

Through the interviewees I got a lot of useful information that validated and enriched my perceptions from earlier in this study. The interviews consisted of numerous open-ended questions and the interviews were typically about one hour long. Following the methods of theory elaborating research approach, these questions 
were supplemented with ones that I saw as useful to pursue during the interviews. I asked the interviewees specific questions about what the key elements in Nordea's business strategy were at different times and also how the bank and its top management emphasized different elements at different times. During the interviews we went through the whole period of time that the interviewee had been on the board or in a top management position at Nordea.

All interviews were recorded and transcribed.

\section{Table 9: Interviews}

\begin{tabular}{lll} 
Date & Name & Position at Nordea \\
\hline 07.11.2014 & Timo Peltola & $\begin{array}{l}\text { A member of the Board of Directors (1998- } \\
2010) \text { and Vice Chairman of the Board } \\
(2002-2008)\end{array}$ \\
26.11.2014 & Carl-Johan Granvik & $\begin{array}{l}\text { Executive Vice President and a member of } \\
\text { Group Executive Management (2000- } \\
2010)\end{array}$ \\
& Markku Pohjola & $\begin{array}{l}\text { Deputy Chief Executive Officer and a } \\
\text { member of Group Executive Management } \\
(2000-2008)\end{array}$
\end{tabular}

\subsubsection{Phase 5: Identification of core elements}

I created explicit criteria to define the core elements based on previous academic literature. Following the suggestion of Ghemawat and Levinthal (2000), I dealt with organizational systems as networks consisting of nodes (organizational elements) and connecting edges (interactions). Core elements are then elements that interact with many current or future organizational elements or that have a large influence on future organizational elements (see also Siggelkow, 2002).

The core elements of organizations have been identified by announcing ex ante a number of critical activity domains and then selecting variables that represent these domains. Core elements are elements that interact with many other current or future organizational elements. Emerging core elements are elements that are not central at 
the time yet become central at a future time. To identify core elements, the concept of interactions among the elements of an organizational system plays a key role (Siggelkow, 2002).

Firstly I identified the core elements in Nordea's organizational system every year between 2000 and 2011. I developed four criteria from the previous literature to operationalize the theoretical definitions of a core element. Specifically, for an element to qualify as a core element it had to meet at least three of the following criteria:

(1) The element is mentioned as important strategic issue in Nordea's annual reports.

(2) The element is logically connected to business operations in a substantial way (subjective-analytical judgment), in other words it has a high interdependency with other current organizational elements.

(3) It is an element that interacts with many current or future organizational elements.

(4) The element is in Nordea's organizational system; in other words, it has a large influence on future organizational elements.

Using these criteria, for example, the element "the Nordic countries as a home market" was recognized as core in 2000 as

(a) it was mentioned as important strategic issue in the bank's strategic statement in Nordea's Annual Report 2000 (Nordea Annual Report 2000: 7); (b) it defines Nordea's geographical focus (home market) and is logically connected to business operations in a substantial way;

(c) it is an element that interacts with six other organizational elements in Nordea's organizational system (see the Nordea organizational-system map in this study, p. 106); and

(d) a part of Nordea's geographical focus that has a large influence on the bank's future organizational elements. 
These criteria also allowed seeing when an element should not be defined as a core element. For example, the element "the adoption of best practices" is not a core element because it does not match all the criteria:

(a) It is mentioned as important strategic issue in the bank's strategic statement in Nordea's Annual Report 2000 (Nordea Annual Report 2000: 10).

(b) It defines the way in which Nordea implements the integration process but it does not have any substantial impact on the bank's overall business operations (although it was an important element in the integration process).

(c) It is an element that only interacts with one other organizational element in Nordea's organizational system (see Nordea's organizational-system map in this study, p. 106).

(d) This element does not have a large influence on the bank's future organizational elements.

This element meets only the first of the four criteria and therefore it is not a core element, but it is an elaborating element for the core element "the rapid integration of Nordic businesses."

I also applied a systematic procedure for checking all the analyzed data to identify core and non-core elements. This ensured that I used the above-defined criteria systematically with all data. Specifically, I used the following process:

(1) Read a sentence from the written material describing the organization.

(2) Check if the statement indicates an element that matches the criteria for core elements.

(3) If at least $3 / 4$ criteria are met, add the code "a core element on the text."

(4) Draw a tentative circle and text with the core element in an organizational system map.

In a similar fashion, I used a systematic process for coding the interdependencies between recognized elements:

(1) Read a sentence from the written material describing the organization. 
(2) Check if the sentence indicates that there is a relationship between two elements named in the sentence.

(3) If there is a clear and logical strategic relationship between two elements, draw a line on an organizational-system map between these two core elements, between a core element and an elaborating element, or between two elaborating elements.

See Tables 10 (Nordea's Core Elements Between 2000-2011) in this study (p. 102).

\subsubsection{Phase 6: Quantitative validation of core elements}

Consistent with Siggelkow (2002) and to complement the qualitative validation process, I conducted a quantitative validation of the core elements in the organizational-system maps.

Siggelkow has dealt with organizational systems as networks consisting of nodes (organizational elements) and connecting edges (interactions) (2002). From Nordea's organizational systems, I identified Nordea's core elements. According to Siggelkow, current core elements are elements that have an impact on many other contemporary organizational elements, in other words, on the elements that are central nodes in the organizational system at a specific time $(t)$. Emerging core elements are on the other hand elements that are not central at time $t$ yet but they become central at a future time.

I have also followed Hannan, Burton, and Baron's (Hannan, Burton, \& Baron, 1996) concept that "coreness means condectedness" and that "elements in the core are linked in complicated webs of relations with each other with peripheral elements."

When coreness means condectedness, how many other elements any given element affects needs to be known. Freeman's (Freeman, 1979) degree of centrality, which measures the number of directly affected elements, is a useful centrality measure. The first column of Table 11 shows the ten elements that have the highest centrality in Nordea's activity system in every year between 2000 and 2011. All the defined 
core elements in the study had the highest degree of centrality in every year during the study period.

Elements may also have more far-reaching consequences than just direct interactions. For example, if element $A$ affects element $B$, which in turn has an impact on element $\mathrm{C}$, and then element $\mathrm{A}$ indirectly affects element $\mathrm{C}$. I have calculated a second-order degree of centrality by also counting the number of elements that any given element affects indirectly via one other element. The second column of Table 11 includes the results with a weighting scheme that equalizes the total effect of direct and second-order interactions. On average each element in Nordea's activity system in 2011 affected 2.67 other elements directly (the average degree of centrality) and 9.81 elements indirectly (via one other element). If $d$ is the Freeman degree of centrality of element $A$ and $m$ is the number of indirect elements $A$ affects, the second-order degree of centrality of $A$ is calculated as $d+$ alpha ${ }^{*} m$. I chose alpha $=2.61 / 9.81=0.272$, so that the first and second term in the calculations of the second-order degree of centrality are equal on average, but the identification of core elements is robust to a wide range of alpha.

See Table 11 (detailing the centrality measures of the ten most central elements in Nordea's organizational system between 2000-2011) on pages 104 - 105.

\subsubsection{Phase 7: Analyzing change in Nordea`s organizational systems}

To analyze the changes in Nordea's organizational systems, I initially used Siggelkow's (2002) method for determining an organization's core elements. In his study Siggelkow identified four processes that describe the creation and subsequent elaboration of these core elements: patching, thickening, coasting, and trimming. This concept allows me to describe the developmental path of Nordea consistently in my study. I also had to develop a fifth concept because the four concepts by Siggelkow did not provide sufficient conceptual tools to describe my data. This fifth concept ultimately emerged as the key theoretical contribution of my dissertation. 


\section{Patching}

An organization adopts many new core elements into the activity system over the course of its history. Siggelkow (2002) termed the process of adopting a new core element, and its subsequent reinforcement "patching." In my study I use the term patching in situations when a new core element gives rise to a new patch in the map of Nordea's activity system. There was one type of new core element in my study: immediate core elements. A new element that is not immediately a core element but becomes core over time through further elaboration is an emerging core element. In my research, I did not identify any emerging core elements.

A new element that is at once central within Nordea's organizational system, interacting directly and indirectly with a large number of the existing organizational elements, is immediately a core element. For example, in 2002 the new President and CEO of Nordea, Lars G. Nordström, emphasized that profitability should be prioritized over growth, and this principle was reflected in the way that Nordea allocates capital (Nordea Annual Review 2002: 20). The principle of "profitability prioritized over growth" was a totally new element that interacted (especially indirectly) with many other existing organizational elements in Nordea's activity system. It was immediately a core element in Nordea's activity system and I have termed the process of adopting this new core element patching.

In one other academic study, patching is defined as the strategic process by which "corporate executives routinely remap businesses to changing market opportunities. It can take the form of adding, splitting, transferring, exiting, or combining chunks of businesses" (Brown \& Eisenhardt, 1997). The patching process described by Brown and Eisenhardt (1997) also includes the concept of spreading a given set of elements into smaller subgroups to better exploit business opportunities, a process for solving highly interdependent decision problems related to the patching procedure.

In my study I have only used "patching" to refer to the adoption of new sets of elements that are highly interdependent with each other (creating a patch) and the contained elements must be strongly interdependent with other elements of Nordea 
and therefore core. This is the same approach that Siggelkow (2002) used in his study.

\section{Thickening}

When an organization adopts new elements into its organizational system, most of these new elements are not new core elements, but they reinforce existing core elements. Siggelkow (2002) termed the process of reinforcing an existing core element with subsequent elaborating elements "thickening," because the process leads to an increasingly thick network of interactions involving the respective core element. According to Siggelkow (2002), over any period of time, any given core element can be further reinforced through the addition of elaborating elements.

In my study when a new element appeared that was linked to a particular core element, I coded it "thickening." I also used the term thickening for the process when former elaborating elements were replaced by new ones. For example, thickening occurred around Nordea's core element "increasing business with existing customers" between 2004 and 2005 (Figures 11 and 12) when this was reinforced by three new elaborating elements: common customer programs, the cross-border launch of products, and a focus on customer relationships.

From 2003 to 2004 thickening occurred around Nordea's core element "a focus on operational excellence" (Figures 10 and 11) when this core element was reinforced by a new elaborating element "product development and time-to-market have a high priority." This elaborating element in fact replaced the former elaborating element "an IT joint venture with IBM."

\section{Coasting}

According to Siggelkow (2002) if a core element in an organizational system is not reinforced over a given period of time, the organization is "coasting" with respect to this core element. In my study of Nordea I have used "coasting" in situations when a core element is not reinforced over given period of time (during one year) and so the organization is said to be coasting with respect to this core element. 
For example, coasting occurred around Nordea's core element "a multi-channel distribution network" from 2003 to 2004 (Figures 10 and 11), when this core element was not reinforced by any new elaborating element.

\section{Trimming}

Siggelkow (2002: 150) termed the process of the deletion of an existing core element and most of its associated elaborating elements "trimming." Siggelkow did not observe the process of trimming in his study of the mutual fund management company Vanguard. He pointed out that the reason for that was partly the fact that "Vanguard never experienced a large number of misfits caused by one of its core elements, it never eliminated one of its core elements."

In my study Nordea never underwent a large number of misfits incurred by one of its core elements, and therefore I have not observed the process of trimming in my study. The main reason for this development was that Nordea had a very consistent business strategy over the study period.

\section{Shaping}

When I was analyzing changes in Nordea's activity system, I realized that some of Nordea's core elements transformed into a new shape over the course of time. In the previous academic literature there was no record of this kind of development process for a core element in an organization's activity system. I termed the process of transforming an existing core element into a new shape over the course of time "shaping."

Shaping refers to a process that maintains the identity of a core element and its links to other core elements and elaborating elements, yet changes the core element in a substantial way. Shaping recognizes the importance of continuous learning in strategy development. It seems inadequate for strategic executives to determine their core elements once and then sectionally review if the core elements continue to be relevant. Rather, strategic executives can generate qualitative changes in the core elements. In the other words, it is not sufficient to consider whether a core element is 
present or not in a digital (on-off) fashion, and a richer understanding of the element and how it operates may be necessary for effective strategy development over time.

For example, shaping is the process when top management transforms or expands its strategic core elements into new shapes to emphasize its strategic focus areas in a new way. This can be seen when the top management of Nordea transformed and expanded the bank's core element and geographic focus of having "the Nordic countries as a home market" in order to take the new shape of "a focus on the Nordic region as well as new European markets" and similarly, the core element of "growing with its customers" took the new shape "increasing business with existing customers."

A further example of shaping was when the top management of Nordea transformed and expanded the bank's core element of a "focus on e-banking" into the new shape of "a multi-channel distribution network." According to the interviewees, the core element of "a focus on e-banking" was shaped into "a multi-channel distribution network" because e-banking was already established and it had a growing amount of customers but the branch network was still an important distribution channel (top manager, 2015). A part of Nordea's top management did not believe that e-banking would be a single distribution channel for the bank in the future (top manager, 2014) and this supported the process of transforming the existing core element "a focus on e-banking" into the new shape of "a multi-channel distribution network." One of the interviewees used the word "shaping" when he described the development process of a multi-channel distribution network (top manager, 2015).

\section{The Identification of Different Processes}

Siggelkow (2002: 125) identified four processes that describe the creation and subsequent elaboration of organizational core elements: patching, thickening, coasting, and trimming. I used this concept in my study to describe the developmental path of Nordea consistently. I also developed a fifth process because Siggelkow's processes did not provide sufficient conceptual tools for describing my data. This fifth process ultimately emerged as the key theoretical contribution of my dissertation. 
When I identified these five different processes in the developmental path of Nordea, my analysis was based on using Siggelkow's criteria for his four processes and my own criterion for the fifth process. The six criteria were as follows:

Criterion 1: A new core element (and its reinforcement) is adopted in Nordea's organizational system (patching).

Criterion 2: A core element in Nordea's organizational-system map is reinforced by a new elaborating element (thickening).

Criterion 3: A former elaborating element is replaced by a new one in the map of Nordea's organizational system (thickening).

Criterion 4: A core element in Nordea's organizational system was not reinforced during one year (coasting).

Criterion 5: A core element and most of its associated elaborating elements were deleted (trimming).

Criterion 6: A core element was transformed into a new shape over a given period (during one year) (shaping).

See Table 12 (The Transformation Process of the Core Elements A, B, C, D, E, and F) on p. 138. 


\section{DATA DESCRIPTION: NORDEA'S ACTIVITY SYSTEMS BETWEEN 2000-2011}

I present my data and findings in two main parts. The first part (Chapter 4) provides a description of Nordea's organizational systems during the study period. This section is analogical to descriptive statistics in quantitative studies. The second part is the main part. It describes the shaping process in more detail.

In this section, I describe Nordea's activity system year by year from 2000 to 2011. This descriptive section shows how Nordea's organizational system contained six core elements during the study period and evolved around them. (But note that the core elements were shaped during the study period, which is why there are two or three versions of each core element.) Table 10 (detailing Nordea's core elements between 2000-2011) shows the core elements (including the different variants of each core element over time), how each of them matches the criteria for core elements, and the results of the quantitative validation for each core element. The subsections below describe in detail, for each year, how the core elements interacted, how they were supported by elaborating elements, and how they changed over time. I detail the organizational systems year by year, showing evidence of the existence of each element in the systems and showing how the elements fitted together. In the figures, numbers in the elements refer to evidence that is presented on p. 186 - 190 Evidences of Nordea's Activity Systems: 2000- 2011 [Appendix A]. For each element I only identified one specific source-even though it was often possible to find multiple pieces of evidence-in order to simplify things.

See Table 10: Nordea's Core Elements Between 2000 - 2011 in the next page. 


\begin{tabular}{|c|c|c|c|c|c|c|c|c|c|}
\hline Criteria & $\begin{array}{l}\text { The average } \\
\text { degree of centrality }\end{array}$ & (1) & $\begin{array}{l}\text { Mentioned as an important } \\
\text { strategic issue in Nordea's } \\
\text { annual report }\end{array}$ & (2) & $\begin{array}{l}\text { Logically connected to } \\
\text { business operations in a } \\
\text { substantial way (subjective- } \\
\text { analytical judgment) }\end{array}$ & (3) & $\begin{array}{l}\text { An element that interacts } \\
\text { with many other current } \\
\text { organizational elements or } \\
\text { will interact with future } \\
\text { elements }\end{array}$ & (4) & $\begin{array}{l}\text { It will have a large influence } \\
\text { on future organizational } \\
\text { elements }\end{array}$ \\
\hline $\begin{array}{l}\text { Core element A: The } \\
\text { Nordic countries as a } \\
\text { home market }\end{array}$ & 4.14 & $\cdot$ & $\begin{array}{l}\text { Mentioned as an important strategic } \\
\text { issue in the CEO's strategy comment } \\
\text { in Nordea's Annual Report 2000: } 7 \text {. }\end{array}$ & $\cdot$ & $\begin{array}{l}\text { This core element defines Nordea's } \\
\text { geographical focus (its home market) } \\
\text { and it is logically connected to } \\
\text { Nordea's business operations in a } \\
\text { substantial way now and it will be in } \\
\text { the future. }\end{array}$ & $\cdot$ & $\begin{array}{l}\text { An element that interacts with six } \\
\text { other organizational elements in } \\
\text { Nordea's organizational system (see } \\
\text { Nordea's organizational System Map } \\
\text { in this study, page 106). }\end{array}$ & $\cdot$ & $\begin{array}{l}\text { A decision about Nordea's } \\
\text { geographical focus will have a large } \\
\text { influence on the bank's future } \\
\text { organizational elements. }\end{array}$ \\
\hline $\begin{array}{l}\text { Core element A1: A focus } \\
\text { on the Nordic region as } \\
\text { well as new European } \\
\text { markets }\end{array}$ & 3.20 & • & $\begin{array}{l}\text { Mentioned as an important strategic } \\
\text { issue in the bank's strategic statement } \\
\text { in Nordea's Annual Report 2007: } 12 \text {. }\end{array}$ & • & $\begin{array}{l}\text { This core element defines Nordea's } \\
\text { new geographical focus (its home } \\
\text { market) and it is logically connected } \\
\text { to Nordea's business operations in a } \\
\text { substantial way now and it will be in } \\
\text { the future. }\end{array}$ & • & $\begin{array}{l}\text { An element that interacts with three } \\
\text { other organizational elements in } \\
\text { Nordea's organizational system (see } \\
\text { Nordea's Organizational System Map } \\
\text { in this study, page 125). }\end{array}$ & $\cdot$ & $\begin{array}{l}\text { A decision about Nordea's new } \\
\text { geographical focus will have a large } \\
\text { influence on the bank's future } \\
\text { organizational elements. }\end{array}$ \\
\hline $\begin{array}{l}\text { Core element B: } \\
\text { A focus on e-banking }\end{array}$ & 5.00 & $\cdot$ & $\begin{array}{l}\text { Mentioned as an important strategic } \\
\text { issue in the CEO's strategy comment } \\
\text { in Nordea's Annual Report 2000: 7-8. }\end{array}$ & $\cdot$ & $\begin{array}{l}\text { This core element defines Nordea's } \\
\text { growth focus in its distribution } \\
\text { channel strategy and it is logically } \\
\text { connected to Nordea's business } \\
\text { operations in a substantial way. }\end{array}$ & $\cdot$ & $\begin{array}{l}\text { An element that interacts with five } \\
\text { other organizational elements in } \\
\text { Nordea's organizational system (see } \\
\text { Nordea's Organizational System Map } \\
\text { in this study, page 106). }\end{array}$ & $\cdot$ & $\begin{array}{l}\text { This core element will have a large } \\
\text { influence on Nordea's future } \\
\text { organizational elements because it } \\
\text { defines the bank's development focus. }\end{array}$ \\
\hline $\begin{array}{l}\text { Core element B1: A multi- } \\
\text { channel distribution } \\
\text { network }\end{array}$ & 4.09 & $\cdot$ & $\begin{array}{l}\text { Mentioned as an important strategic } \\
\text { issue in the bank's strategic statement } \\
\text { in Nordea's Annual Report 2001: } 23 \text {. }\end{array}$ & $\cdot$ & $\begin{array}{l}\text { This core element defines Nordea's } \\
\text { distribution channel network strategy } \\
\text { and it has a substantial impact on the } \\
\text { bank's operations now and it will in } \\
\text { the future. }\end{array}$ & • & $\begin{array}{l}\text { An element that interacts with five } \\
\text { other organizational elements in } \\
\text { Nordea's organizational system (see } \\
\text { Nordea's Organizational System Map } \\
\text { in this study, page 110). }\end{array}$ & & $\begin{array}{l}\text { A decision about Nordea's distribution } \\
\text { channel network strategy will have a } \\
\text { large influence on the bank's future } \\
\text { organizational elements. }\end{array}$ \\
\hline $\begin{array}{l}\text { Core element C: Growing } \\
\text { with its customers }\end{array}$ & 5.00 & • & $\begin{array}{l}\text { Mentioned as an important strategic } \\
\text { issue in the bank's strategic statement } \\
\text { in Nordea's Annual Report 2000: } 10 \text {. }\end{array}$ & $\cdot$ & $\begin{array}{l}\text { This core element defines Nordea's } \\
\text { growth strategy and has a substantial } \\
\text { impact on the bank's operations. }\end{array}$ & $\cdot$ & $\begin{array}{l}\text { An element that interacts with five } \\
\text { other organizational elements in } \\
\text { Nordea's organizational system (see } \\
\text { Nordea's Organizational System Map } \\
\text { in this study, page 106). }\end{array}$ & & $\begin{array}{l}\text { By defining Nordea's growth focus this } \\
\text { core element will have a large } \\
\text { influence on the bank's future } \\
\text { organizational elements. }\end{array}$ \\
\hline $\begin{array}{l}\text { Core element C1: } \\
\text { Increasing business with } \\
\text { existing customers }\end{array}$ & 7.60 & • & $\begin{array}{l}\text { Mentioned as an important strategic } \\
\text { issue in the bank's strategic statement } \\
\text { in Nordea's Annual Review 2002: } 19 .\end{array}$ & $\cdot$ & $\begin{array}{l}\text { This core element emphasizes that } \\
\text { Nordea's growth strategy focuses on } \\
\text { increasing the share of wallet and it } \\
\text { has a substantial impact to the bank's } \\
\text { operations. }\end{array}$ & • & $\begin{array}{l}\text { An element that interacts with four } \\
\text { other organizational elements in } \\
\text { Nordea's organizational system (see } \\
\text { Nordea's Organizational System Map } \\
\text { in this study, page 113). }\end{array}$ & & $\begin{array}{l}\text { By defining Nordea's new growth and } \\
\text { customer focus this core element will } \\
\text { have a large influence on the bank's } \\
\text { future organizational elements. }\end{array}$ \\
\hline $\begin{array}{l}\text { Core element D: The rapid } \\
\text { integration of Nordic } \\
\text { businesses }\end{array}$ & 5.00 & • & $\begin{array}{l}\text { Mentioned as an important strategic } \\
\text { issue in the CEO's strategy comment } \\
\text { in Nordea's Annual Report 2000: } 6 \text {. }\end{array}$ & $\cdot$ & $\begin{array}{l}\text { This core element emphasizes that } \\
\text { after mergers Nordea is focusing on } \\
\text { rapid integration and this has a } \\
\text { substantial impact on the bank's } \\
\text { operations. }\end{array}$ & • & $\begin{array}{l}\text { An element that interacts with five } \\
\text { other organizational elements in } \\
\text { Nordea's organizational system (see } \\
\text { Nordea's Organizational System Map } \\
\text { in this study, page 106). }\end{array}$ & & $\begin{array}{l}\text { This core element emphasizes the } \\
\text { importance of rapid integration after } \\
\text { mergers and it will have a large } \\
\text { influence on the bank's future } \\
\text { organizational elements. }\end{array}$ \\
\hline $\begin{array}{l}\text { Core element D1: Building } \\
\text { an integrated banking } \\
\text { group }\end{array}$ & 4.00 & • & $\begin{array}{l}\text { Mentioned as an important strategic } \\
\text { issue in the bank's strategic statement } \\
\text { in Nordea's Annual Report 2001: } 23 \text {. }\end{array}$ & • & $\begin{array}{l}\text { This core element emphasizes that } \\
\text { the next step needs to be taken } \\
\text { towards building an integrated } \\
\text { banking group by increasing the } \\
\text { benefitt of scale and size, and it is } \\
\text { logically connected to business } \\
\text { operations in a substantial way. }\end{array}$ & • & $\begin{array}{l}\text { An element that interacts with five } \\
\text { other organizational elements in } \\
\text { Nordea's organizational system (see } \\
\text { Nordea's Organizational System Map } \\
\text { in this study, page 110). }\end{array}$ & & $\begin{array}{l}\text { This core element emphasizes the role } \\
\text { of the benefits of scale and size and it } \\
\text { will have a large operational influence } \\
\text { on the bank's future organizational } \\
\text { elements. }\end{array}$ \\
\hline $\begin{array}{l}\text { Core element D2: An } \\
\text { integrated banking group }\end{array}$ & 5.60 & • & $\begin{array}{l}\text { Mentioned as important strategic } \\
\text { issue in the bank's strategic statement } \\
\text { in Nordea's Annual Report 2002: 7. }\end{array}$ & $\cdot$ & $\begin{array}{l}\text { This core element emphasizes the } \\
\text { importance of using the benefits of } \\
\text { scale and size, and it has a substantial } \\
\text { impact to the bank's operations. }\end{array}$ & • & $\begin{array}{l}\text { An element that interacts with five } \\
\text { other organizational elements in } \\
\text { Nordea's organizational system (see } \\
\text { Nordea's Organizational System Map } \\
\text { in this study, page 113). }\end{array}$ & & $\begin{array}{l}\text { This core element emphasizes the role } \\
\text { of the benefits of scale and size, and it } \\
\text { will have a large operational influence } \\
\text { on the bank's future organizational } \\
\text { elements. }\end{array}$ \\
\hline $\begin{array}{l}\text { Core element D3: One } \\
\text { operating model }\end{array}$ & 4.80 & • & $\begin{array}{l}\text { Mentioned as an important strategic } \\
\text { issue in the bank's strategic statement } \\
\text { in Nordea's Annual Report 2007: } 17 \text {. }\end{array}$ & • & $\begin{array}{l}\text { This core element defines Nordea's } \\
\text { new operating model and it has a } \\
\text { substantial impact on the bank's } \\
\text { business operations. }\end{array}$ & • & $\begin{array}{l}\text { An element that interacts with ten } \\
\text { other organizational elements in } \\
\text { Nordea's organizational system (see } \\
\text { Nordea's Organizational System Map } \\
\text { in this study, page 125). }\end{array}$ & & $\begin{array}{l}\text { By defining Nordea's new operating } \\
\text { model this core element will have a } \\
\text { large influence on Nordea's future } \\
\text { organizational elements. }\end{array}$ \\
\hline $\begin{array}{l}\text { Core element E: A focus } \\
\text { on operational excellence }\end{array}$ & 6.75 & • & $\begin{array}{l}\text { Mentioned as important strategic } \\
\text { issue in the bank's strategic statement } \\
\text { in Nordea's Annual Review 2003: } 17 \text {. }\end{array}$ & $\cdot$ & $\begin{array}{l}\text { This core element defines how } \\
\text { Nordea should operate and it is } \\
\text { logically connected to the bank's } \\
\text { business operations in a substantial } \\
\text { way. }\end{array}$ & • & $\begin{array}{l}\text { An element that interacts with eight } \\
\text { other organizational elements in } \\
\text { Nordea's organizational system (see } \\
\text { Nordea's Organizational System Map } \\
\text { in this study, page 116). }\end{array}$ & $\cdot$ & $\begin{array}{l}\text { By defining how to operate this core } \\
\text { element will have a large influence on } \\
\text { Nordea's future organizational } \\
\text { elements. }\end{array}$ \\
\hline $\begin{array}{l}\text { Core element E1: } \\
\text { Operational efficiency }\end{array}$ & 5.00 & • & $\begin{array}{l}\text { Mentioned as an important strategic } \\
\text { issue in the bank's strategic statement } \\
\text { in Nordea's Annual Report 2007: } 14 .\end{array}$ & • & $\begin{array}{l}\text { This core element defines how } \\
\text { Nordea should operate and is logically } \\
\text { connected to business operations in a } \\
\text { substantial way. }\end{array}$ & • & $\begin{array}{l}\text { An element that interacts with six } \\
\text { other organizational elements in } \\
\text { Nordea's organizational system (see } \\
\text { Nordea's Organizational System Map } \\
\text { in this study, page 125). }\end{array}$ & & $\begin{array}{l}\text { By defining how to operate this core } \\
\text { element will have a large influence on } \\
\text { Nordea's future organizational } \\
\text { elements. }\end{array}$ \\
\hline $\begin{array}{l}\text { Core element F: } \\
\text { Profitability prioritized } \\
\text { over growth }\end{array}$ & 4.00 & • & $\begin{array}{l}\text { Mentioned as an important strategic } \\
\text { issue in the CEO's strategy comment } \\
\text { in Nordea's Annual Report 2002: } 6 \text {. }\end{array}$ & $\cdot$ & $\begin{array}{l}\text { This core element emphasizes that } \\
\text { Nordea's business focus should be on } \\
\text { profitability before growth and it has } \\
\text { a substantial impact on the bank's } \\
\text { business operations. }\end{array}$ & • & $\begin{array}{l}\text { An element that interacts with six } \\
\text { other organizational elements in } \\
\text { Nordea's organizational system (see } \\
\text { Nordea's Organizational System Map } \\
\text { in this study, page 113). }\end{array}$ & & $\begin{array}{l}\text { By defining Nordea's business focus } \\
\text { this core element will have a large } \\
\text { influence on the bank's future } \\
\text { organizational elements. }\end{array}$ \\
\hline $\begin{array}{l}\text { Core element F1: Efficient } \\
\text { capital management }\end{array}$ & 5.25 & • & $\begin{array}{l}\text { Mentioned as important strategic } \\
\text { issue in the bank's strategic statement } \\
\text { in Nordea's Annual Review 2003: } 17 .\end{array}$ & $\cdot$ & $\begin{array}{l}\text { This core element defines how } \\
\text { Nordea tries to improve its } \\
\text { profitability and it is logically } \\
\text { connected to business operations in a } \\
\text { substantial way. }\end{array}$ & $\cdot$ & $\begin{array}{l}\text { An element that interacts with six } \\
\text { other organizational elements in } \\
\text { Nordea's organizational system (see } \\
\text { Nordea's Organizational System Map } \\
\text { in this study, page 116). }\end{array}$ & & $\begin{array}{l}\text { By defining how to improve } \\
\text { profitability this core element will } \\
\text { have a large influence on Nordea's } \\
\text { future organizational elements. }\end{array}$ \\
\hline $\begin{array}{l}\text { Core element F2: Profit } \\
\text { orientation }\end{array}$ & 8.60 & $\cdot$ & $\begin{array}{l}\text { Mentioned as important strategic } \\
\text { issue in the bank's strategic statement } \\
\text { in Nordea's Annual Report 2007: } 12 \text {. }\end{array}$ & $\cdot$ & $\begin{array}{l}\text { This core element defines that Nordea } \\
\text { is focused on profitability in its } \\
\text { operations and this core element is } \\
\text { logically connected to business } \\
\text { operations in a substantial way. }\end{array}$ & $\cdot$ & $\begin{array}{l}\text { An element that interacts with three } \\
\text { other organizational elements in } \\
\text { Nordea's organizational system (see } \\
\text { Nordea's Organizational System Map } \\
\text { in this study, page 125). }\end{array}$ & $\cdot$ & $\begin{array}{l}\text { By defining Nordea's business focus, } \\
\text { this core element will have a large } \\
\text { influence on the bank's future } \\
\text { organizational elements. }\end{array}$ \\
\hline
\end{tabular}


Table 11 shows the centrality measures of the ten most central elements in Nordea's organizational system between 2000 - 2011. The first column of Table 11 shows the ten elements that have the highest centrality in Nordea's activity system in every year between 2000 and 2011. The second column of Table 11 includes the results with a weighting scheme that equalizes the total effect of direct and secondorder interactions.

See Table 11: The Centrality Measures of the Ten Most Central Elements in Nordea's Organizational System Between 2000 - 2011 on pages 104- 105. 


\begin{tabular}{|c|c|c|c|c|c|c|c|c|c|}
\hline Rank & Element* & $\begin{array}{l}\text { Centrality } \\
\text { Degree }\end{array}$ & Element* & $\begin{array}{l}\text { Second- } \\
\text { Order } \\
\text { Degree }\end{array}$ & Rank & Element* & $\begin{array}{l}\text { Centrality } \\
\text { Degree }\end{array}$ & Element* & $\begin{array}{l}\text { Second- } \\
\text { Order } \\
\text { Degree }\end{array}$ \\
\hline \multicolumn{5}{|l|}{2000} & \multicolumn{5}{|l|}{2001} \\
\hline 1. & $\begin{array}{ll}\text { The } & \text { Nordic } \\
\text { countries as a } \\
\text { home market }\end{array}$ & 6 & $\begin{array}{l}\text { The } \\
\text { countries as a a } \\
\text { home market }\end{array}$ & 11.04 & 1. & $\begin{array}{l}\text { The } \quad \text { Nordic } \\
\text { countries as a } \\
\text { home market }\end{array}$ & 6 & $\begin{array}{l}\text { The } \\
\text { countries as ardic } \\
\text { home market }\end{array}$ & 8.55 \\
\hline 2. & $\begin{array}{l}\begin{array}{l}\text { Focus on } \\
\text { banking }\end{array} \\
\end{array}$ & 5 & $\begin{array}{l}\begin{array}{l}\text { Focus on } \\
\text { banking }\end{array} \\
\end{array}$ & 10.38 & 2. & $\begin{array}{l}\text { A multi-channel } \\
\text { distribution } \\
\text { network }\end{array}$ & 5 & $\begin{array}{l}\text { A multi-channel } \\
\text { distribution } \\
\text { network }\end{array}$ & 7.21 \\
\hline 3. & $\begin{array}{l}\text { Growing with } \\
\text { existing customers }\end{array}$ & 5 & $\begin{array}{l}\text { Growing with } \\
\text { existing customers }\end{array}$ & 9.03 & 3. & $\begin{array}{l}\text { Growing with } \\
\text { existing customers }\end{array}$ & 5 & $\begin{array}{l}\text { Growing with } \\
\text { existing customers }\end{array}$ & 6.87 \\
\hline 4. & $\begin{array}{l}\text { The rapid } \\
\text { integration of } \\
\text { Nordic businesses }\end{array}$ & 5 & $\begin{array}{ll}\begin{array}{l}\text { Products } \\
\text { distribution }\end{array} & \text { and } \\
\text { channels } & \text { are } \\
\text { coordinated } & \text { and } \\
\text { integrated } & \\
\end{array}$ & 8.38 & 4. & $\begin{array}{l}\text { Building an } \\
\text { integrated banking } \\
\text { group }\end{array}$ & 4 & $\begin{array}{l}\text { Decisions are } \\
\text { made close to the } \\
\text { customers }\end{array}$ & 5.21 \\
\hline 5. & $\begin{array}{ll}\begin{array}{l}\text { Products } \\
\text { distribution } \\
\text { channels }\end{array} & \text { and } \\
\text { coordinated } & \text { and } \\
\text { integrated } & \\
\end{array}$ & 3 & $\begin{array}{l}\text { The rapid } \\
\text { integration of } \\
\text { Nordic businesses }\end{array}$ & 7.69 & 5. & $\begin{array}{l}\text { Decisions are } \\
\text { made close to the } \\
\text { customers }\end{array}$ & 3 & $\begin{array}{l}\text { Building an } \\
\text { integrated banking } \\
\text { group }\end{array}$ & 5.02 \\
\hline 6. & $\begin{array}{l}\text { Decisions are } \\
\text { made close to the } \\
\text { customers }\end{array}$ & 3 & $\begin{array}{l}\text { Decisions are } \\
\text { made close to the } \\
\text { customers }\end{array}$ & 6.70 & 6. & $\begin{array}{l}\text { For every business } \\
\text { area, there is one } \\
\text { and only one best } \\
\text { way }\end{array}$ & 2 & $\begin{array}{l}\text { For every business } \\
\text { area, there is one } \\
\text { and only one best } \\
\text { way }\end{array}$ & 3.53 \\
\hline 7. & $\begin{array}{l}\text { A multi-channel } \\
\text { distribution } \\
\text { network }\end{array}$ & 3 & $\begin{array}{l}\text { A multi-channel } \\
\text { distribution } \\
\text { network }\end{array}$ & 5.35 & 7. & Easy to access & 2 & Easy to access & 3.02 \\
\hline 8. & $\begin{array}{l}\text { Harmonizing } \\
\text { customer concepts }\end{array}$ & 2 & $\begin{array}{l}\text { Harmonizing } \\
\text { customers } \\
\text { concepts }\end{array}$ & 4.69 & 8. & $\begin{array}{l}\text { Top-ranking e- } \\
\text { banking services }\end{array}$ & 2 & $\begin{array}{l}\text { Top-ranking e- } \\
\text { banking services }\end{array}$ & 2.85 \\
\hline 9. & \begin{tabular}{lr} 
An & integrated \\
internet & portal \\
covers r most \\
financial products \\
\multicolumn{2}{l}{ and services } \\
\end{tabular} & 2 & $\begin{array}{lr}\text { An integrated } \\
\text { internet r portal } \\
\text { covers most } \\
\text { financial products } \\
\text { and services } \\
\end{array}$ & 4.02 & 9. & $\begin{array}{l}\text { The Baltic Sea } \\
\text { region as an } \\
\text { emerging home } \\
\text { market }\end{array}$ & 1 & $\begin{array}{l}\text { The Baltic Sea } \\
\text { region as an } \\
\text { emerging home } \\
\text { market }\end{array}$ & 1.85 \\
\hline 10. & $\begin{array}{l}\text { The emerging } \\
\text { home market of } \\
\text { Poland and the } \\
\text { Baltic countries }\end{array}$ & 1 & $\begin{array}{l}\text { The emerging } \\
\text { home market of } \\
\text { Poland and the } \\
\text { Baltic countries }\end{array}$ & 2.68 & 10. & $\begin{array}{l}\text { All core } \\
\text { businesses } \\
\text { branded Nordea }\end{array}$ & 1 & $\begin{array}{l}\text { All core } \\
\text { businesses } \\
\text { branded Nordea }\end{array}$ & 1.68 \\
\hline \multicolumn{5}{|l|}{2002} & \multicolumn{5}{|l|}{2003} \\
\hline 1. & $\begin{array}{l}\text { Profitability } \\
\text { prioritized } \\
\text { growth }\end{array}$ & 6 & $\begin{array}{l}\text { Increasing } \\
\text { business with } \\
\text { existing customers }\end{array}$ & 9.03 & 1. & $\begin{array}{lr}\text { A focus on } \\
\text { operational } \\
\text { excellence }\end{array}$ & 8 & $\begin{array}{l}\text { An integrated } \\
\text { banking group }\end{array}$ & 11.35 \\
\hline 2. & $\begin{array}{l}\text { An integrated } \\
\text { banking group }\end{array}$ & 5 & $\begin{array}{l}\text { The } \\
\text { countries as ardic } \\
\text { home market }\end{array}$ & 8.19 & 2. & $\begin{array}{l}\text { An integrated } \\
\text { banking group }\end{array}$ & 6 & $\begin{array}{lrl}A \quad \text { focus } & \text { on } \\
\text { operational } & \\
\text { excellence } & \\
\end{array}$ & 11.27 \\
\hline 3. & $\begin{array}{l}\text { Increasing } \\
\text { business with } \\
\text { existing customers }\end{array}$ & 4 & $\begin{array}{l}\text { An integrated } \\
\text { banking group }\end{array}$ & 7.93 & 3. & $\begin{array}{l}\text { Efficient capital } \\
\text { management }\end{array}$ & 6 & $\begin{array}{l}\text { Increasing } \\
\text { business with } \\
\text { existing customers }\end{array}$ & 10.35 \\
\hline 4. & $\begin{array}{l}\text { The } \quad \text { Nordic } \\
\text { countries as a } \\
\text { home market }\end{array}$ & 4 & 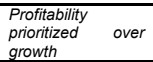 & 7.68 & 4. & $\begin{array}{l}\text { Increasing } \\
\text { business with } \\
\text { existing customers }\end{array}$ & 5 & $\begin{array}{l}\text { Efficient capital } \\
\text { management }\end{array}$ & 8.67 \\
\hline 5. & $\begin{array}{l}\text { A multi-channel } \\
\text { distribution } \\
\text { network }\end{array}$ & 4 & $\begin{array}{l}\text { A multi-channel } \\
\text { distribution } \\
\text { network } \\
\end{array}$ & 7.35 & 5. & $\begin{array}{l}\text { The Nordic } \\
\text { countries as a } \\
\text { home market }\end{array}$ & 4 & $\begin{array}{l}\text { The } \quad \text { Nordic } \\
\text { countries as a } \\
\text { home market }\end{array}$ & 7.56 \\
\hline 6. & $\begin{array}{lrl}A \quad \text { focus } & \text { on } \\
\text { operational } & \\
\text { excellence } & \\
\end{array}$ & 4 & $\begin{array}{lrl}A \quad \text { focus } & \text { on } \\
\text { operational } & \\
\text { excellence } & \\
\end{array}$ & 6.10 & 6. & $\begin{array}{l}\text { A multi-channel } \\
\text { distribution } \\
\text { network }\end{array}$ & 3 & Centralization & 5.56 \\
\hline 7. & $\begin{array}{ll}\text { Acquiring } & \text { new } \\
\text { profitable } & \\
\text { customers } & \\
\end{array}$ & 2 & $\begin{array}{ll}\text { Acquiring } & \text { new } \\
\text { profitable } & \\
\text { customers } & \\
\end{array}$ & 4.93 & 7. & Centralization & 2 & Standardization & 5.56 \\
\hline 8. & $\begin{array}{l}\text { Benchmarking } \\
\text { within the group }\end{array}$ & 2 & $\begin{array}{l}\text { Benchmarking } \\
\text { within the group }\end{array}$ & 4.93 & 8. & Standardization & 2 & Unification & 5.56 \\
\hline 9. & $\begin{array}{l}\text { Speed-up } \\
\text { integration }\end{array}$ & 2 & $\begin{array}{l}\text { Speed-up } \\
\text { integration }\end{array}$ & 4.93 & 9. & Unification & 2 & $\begin{array}{l}\text { A multi-channel } \\
\text { distribution } \\
\text { network }\end{array}$ & 5.08 \\
\hline 10. & $\begin{array}{l}\text { Top-ranking e- } \\
\text { banking services }\end{array}$ & 2 & $\begin{array}{l}\text { Top-ranking e- } \\
\text { banking services }\end{array}$ & 3.68 & 10. & Reduce complexity & 1 & Reduce complexity & 3.08 \\
\hline \multicolumn{5}{|l|}{2004} & \multicolumn{5}{|l|}{2005} \\
\hline 1. & $\begin{array}{l}\text { A focus on } \\
\text { operational } \\
\text { excellence }\end{array}$ & 8 & $\begin{array}{lr}\text { A focus on } \\
\text { operational } \\
\text { excellence }\end{array}$ & 11.22 & 1. & $\begin{array}{l}\text { Increasing } \\
\text { business with } \\
\text { existing customers }\end{array}$ & 8 & $\begin{array}{l}\text { Increasing } \\
\text { business with } \\
\text { existing customers }\end{array}$ & 10.97 \\
\hline 2. & $\begin{array}{l}\text { Efficient capital } \\
\text { management }\end{array}$ & 6 & $\begin{array}{l}\text { Increasing } \\
\text { business with } \\
\text { existing customers }\end{array}$ & 10.47 & 2. & $\begin{array}{l}\text { Efficient capital } \\
\text { management }\end{array}$ & 6 & $\begin{array}{l}\text { Efficient capital } \\
\text { management }\end{array}$ & 7.78 \\
\hline 3. & $\begin{array}{l}\text { Increasing } \\
\text { business with } \\
\text { existing customers }\end{array}$ & 5 & $\begin{array}{l}\text { An integrated } \\
\text { banking group }\end{array}$ & 9.83 & 3. & $\begin{array}{lr}\text { A focus on } \\
\text { operational } \\
\text { excellence }\end{array}$ & 5 & $\begin{array}{lr}\text { A focus on } \\
\text { operational } \\
\text { excellence }\end{array}$ & 6.58 \\
\hline 4. & $\begin{array}{l}\text { An integrated } \\
\text { banking group }\end{array}$ & 5 & $\begin{array}{l}\text { Efficient capital } \\
\text { management }\end{array}$ & 8.58 & 4. & $\begin{array}{l}\text { An integrated } \\
\text { banking group }\end{array}$ & 4 & $\begin{array}{l}A n \text { integrated } \\
\text { banking group }\end{array}$ & 5.98 \\
\hline 5. & $\begin{array}{l}\text { A multi-channel } \\
\text { distribution } \\
\text { network }\end{array}$ & 4 & $\begin{array}{l}\text { A multi-channel } \\
\text { distribution } \\
\text { network }\end{array}$ & 5.93 & 5. & $\begin{array}{l}\text { A multi-channel } \\
\text { distribution } \\
\text { network }\end{array}$ & 4 & $\begin{array}{l}\text { A multi-channel } \\
\text { distribution } \\
\text { network }\end{array}$ & 5.78 \\
\hline 6. & $\begin{array}{l}\text { The } \\
\text { countries as a a } \\
\text { home market }\end{array}$ & 3 & Centralization & 5.54 & 6. & $\begin{array}{l}\text { The Nordic } \\
\text { countries as a } \\
\text { home market }\end{array}$ & 3 & $\begin{array}{l}\text { The } \\
\text { countries as ardic } \\
\text { home market }\end{array}$ & 4.98 \\
\hline 7. & Centralization & 2 & Standardization & 5.54 & 7. & $\begin{array}{l}\text { Cross-border } \\
\text { launch of products }\end{array}$ & 2 & $\begin{array}{l}\text { Cross-border } \\
\text { launch of products }\end{array}$ & 3.98 \\
\hline 8. & Standardization & 2 & Unification & 5.54 & 8. & $\begin{array}{l}\text { Common customer } \\
\text { programs }\end{array}$ & 2 & $\begin{array}{l}\text { Common customer } \\
\text { programs }\end{array}$ & 3.39 \\
\hline 9. & Unification & 2 & $\begin{array}{l}\text { The Nordic } \\
\text { countries as a } \\
\text { home market }\end{array}$ & 5.25 & 9. & $\begin{array}{l}\text { Attract a new high- } \\
\text { value customer } \\
\text { base }\end{array}$ & 1 & $\begin{array}{l}\text { Attract a new high- } \\
\text { value customer } \\
\text { base }\end{array}$ & 2.39 \\
\hline 10. & $\begin{array}{l}\text { Strict } \\
\text { management }\end{array}$ & 1 & $\begin{array}{l}\text { Strict } \\
\text { management }\end{array}$ & 3.25 & 10. & $\begin{array}{ll}\text { A focus } & \text { on } \\
\text { customer } & \\
\text { relationship } & \\
\text { management } & \\
\end{array}$ & 1 & $\begin{array}{ll}\text { A focus on } \\
\text { customers } \\
\text { relationship } \\
\text { management }\end{array}$ & 2.39 \\
\hline
\end{tabular}




\begin{tabular}{|c|c|c|c|c|c|c|c|c|c|}
\hline Rank & Element* & $\begin{array}{l}\text { Centrality } \\
\text { Degree }\end{array}$ & Element* & $\begin{array}{l}\text { Second- } \\
\text { Order } \\
\text { Degree }\end{array}$ & Rank & Element* & $\begin{array}{l}\text { Centrality } \\
\text { Degree }\end{array}$ & Element* & $\begin{array}{l}\text { Second- } \\
\text { Order } \\
\text { Degree }\end{array}$ \\
\hline \multicolumn{5}{|l|}{2006} & \multicolumn{5}{|l|}{2007} \\
\hline 1. & $\begin{array}{l}\text { Increasing } \\
\text { business with } \\
\text { existing customers }\end{array}$ & 8 & $\begin{array}{l}\text { Increasing } \\
\text { business with } \\
\text { existing customers }\end{array}$ & 11.01 & 1. & $\begin{array}{l}\text { One operating } \\
\text { model }\end{array}$ & 10 & $\begin{array}{l}\text { One } \\
\text { model }\end{array}$ & 13.50 \\
\hline 2. & $\begin{array}{l}\text { Efficient capital } \\
\text { management }\end{array}$ & 6 & $\begin{array}{l}\text { Efficient capital } \\
\text { management }\end{array}$ & 9.01 & 2. & $\begin{array}{l}\text { Increasing } \\
\text { business with } \\
\text { existing customers }\end{array}$ & 8 & $\begin{array}{l}\text { Increasing } \\
\text { business with } \\
\text { existing customers }\end{array}$ & 10.00 \\
\hline 3. & $\begin{array}{l}\text { Operational } \\
\text { Efficiency }\end{array}$ & 5 & $\begin{array}{l}\text { An integrated } \\
\text { banking group }\end{array}$ & 7.01 & 3. & $\begin{array}{l}\text { Operational } \\
\text { efficiency }\end{array}$ & 6 & $\begin{array}{l}\text { Operational } \\
\text { efficiency }\end{array}$ & 9.50 \\
\hline 4. & $\begin{array}{l}\text { An integrated } \\
\text { banking group }\end{array}$ & 4 & $\begin{array}{l}\begin{array}{l}\text { Operational } \\
\text { efficiency }\end{array} \\
\end{array}$ & 6.38 & 4. & $\begin{array}{l}\text { A multi-channel } \\
\text { distribution } \\
\text { network } \\
\end{array}$ & 4 & $\begin{array}{l}\text { A multi-channel } \\
\text { distribution } \\
\text { network } \\
\end{array}$ & 8.50 \\
\hline 5. & $\begin{array}{l}\text { A multi-channel } \\
\text { distribution } \\
\text { network }\end{array}$ & 3 & $\begin{array}{l}\text { Resource } \\
\text { optimization }\end{array}$ & 6.13 & 5. & $\begin{array}{l}\text { A focus on the } \\
\text { Nordic region as } \\
\text { well as new } \\
\text { European markets }\end{array}$ & 3 & $\begin{array}{l}\text { A focus on the } \\
\text { Nordic region as } \\
\text { well as new } \\
\text { European markets }\end{array}$ & 7.75 \\
\hline 6. & $\begin{array}{l}\text { The } \quad \text { Nordic } \\
\text { countries as a } \\
\text { home market }\end{array}$ & 3 & $\begin{array}{l}\text { A multi-channel } \\
\text { distribution } \\
\text { network }\end{array}$ & 6.01 & 6. & Profit orientation & 3 & Profit orientation & 6.00 \\
\hline 7. & $\begin{array}{l}\text { Resource } \\
\text { optimization }\end{array}$ & 2 & $\begin{array}{l}\text { The Nordic } \\
\text { countries as a } \\
\text { home market }\end{array}$ & 6.01 & 7. & $\begin{array}{l}\text { Strong customer } \\
\text { orientation }\end{array}$ & 2 & $\begin{array}{l}\text { Strong customer } \\
\text { orientation }\end{array}$ & 6.00 \\
\hline 8. & $\begin{array}{l}\text { Cross- } \\
\text { organizational } \\
\text { processes }\end{array}$ & 2 & $\begin{array}{l}\text { Cross- } \\
\text { organizational } \\
\text { processes }\end{array}$ & 4.41 & 8. & $\begin{array}{l}\text { Resource } \\
\text { optimization }\end{array}$ & 2 & $\begin{array}{l}\begin{array}{l}\text { Resource } \\
\text { optimization }\end{array} \\
\end{array}$ & 5.50 \\
\hline 9. & $\begin{array}{l}\text { Harmonizing } \\
\text { products, } \\
\text { processes and IT- } \\
\text { platforms }\end{array}$ & 2 & $\begin{array}{l}\text { Harmonizing } \\
\text { products, } \\
\text { processes and IT- } \\
\text { platforms }\end{array}$ & 4.41 & 9. & Unified IT-systems & 2 & Unified IT-systems & 5.50 \\
\hline 10. & $\begin{array}{l}\text { Attract a new } \\
\text { high-value } \\
\text { customer base }\end{array}$ & 1 & $\begin{array}{l}\text { Attract a new high- } \\
\text { value customer } \\
\text { base }\end{array}$ & 3.41 & 10. & $\begin{array}{l}\text { Cross- } \\
\text { organizational } \\
\text { processes }\end{array}$ & 2 & $\begin{array}{l}\text { Cross- } \\
\text { organizational } \\
\text { processes }\end{array}$ & 5.50 \\
\hline \multicolumn{5}{|l|}{2008} & \multicolumn{5}{|l|}{2009} \\
\hline 1. & $\begin{array}{l}\text { Increasing } \\
\text { business with } \\
\text { existing customers }\end{array}$ & 10 & $\begin{array}{l}\text { Increasing } \\
\text { business with } \\
\text { existing customers }\end{array}$ & 13.70 & 1. & $\begin{array}{l}\text { Increasing } \\
\text { business with } \\
\text { existing customers }\end{array}$ & 10 & $\begin{array}{l}\text { Increasing } \\
\text { business with } \\
\text { existing customers }\end{array}$ & 14.87 \\
\hline 2. & $\begin{array}{ll}\begin{array}{l}\text { One } \\
\text { model }\end{array} & \text { operating } \\
\end{array}$ & 9 & $\begin{array}{ll}\begin{array}{l}\text { One } \\
\text { model }\end{array} & \text { operating } \\
\end{array}$ & 13.62 & 2. & $\begin{array}{ll}\begin{array}{l}\text { One } \\
\text { model }\end{array} & \text { operating } \\
\end{array}$ & 9 & $\begin{array}{ll}\begin{array}{l}\text { One } \\
\text { model }\end{array} & \text { operating } \\
\end{array}$ & 13.41 \\
\hline 3. & $\begin{array}{l}\text { Operational } \\
\text { efficiency }\end{array}$ & 5 & $\begin{array}{l}\text { A multi-channel } \\
\text { distribution } \\
\text { network }\end{array}$ & 9.31 & 3. & $\begin{array}{l}\text { Operational } \\
\text { efficiency }\end{array}$ & 5 & $\begin{array}{l}\begin{array}{l}\text { Operational } \\
\text { efficiency }\end{array} \\
\end{array}$ & 8.94 \\
\hline 4. & $\begin{array}{l}\text { A multi-channel } \\
\text { distribution } \\
\text { network } \\
\end{array}$ & 4 & $\begin{array}{l}\text { Operational } \\
\text { efficiency }\end{array}$ & 8.70 & 4. & Profit orientation & 5 & $\begin{array}{l}\text { A multi-channel } \\
\text { distribution } \\
\text { network } \\
\end{array}$ & 8.64 \\
\hline 5. & Profit orientation & 4 & $\begin{array}{l}\text { A focus on the } \\
\text { Nordic region as } \\
\text { well as new } \\
\text { European markets }\end{array}$ & 7.62 & 5. & $\begin{array}{l}\text { A multi-channel } \\
\text { distribution } \\
\text { network }\end{array}$ & 4 & Profit orientation & 8.02 \\
\hline 6. & $\begin{array}{l}\text { A focus on the } \\
\text { Nordic region as } \\
\text { well as new } \\
\text { European markets }\end{array}$ & 3 & Profit orientation & 7.00 & 6. & $\begin{array}{l}\text { A focus on the } \\
\text { Nordic region as } \\
\text { well as new } \\
\text { European markets }\end{array}$ & 3 & $\begin{array}{l}\text { A focus on the } \\
\text { Nordic region as } \\
\text { well as new } \\
\text { European markets }\end{array}$ & 7.64 \\
\hline 7. & $\begin{array}{l}\text { Cross- } \\
\text { organizational } \\
\text { processes }\end{array}$ & 2 & $\begin{array}{l}\text { Cross- } \\
\text { organizational } \\
\text { processes }\end{array}$ & 4.77 & 7. & $\begin{array}{l}\text { Cross- } \\
\text { organizational } \\
\text { processes }\end{array}$ & 2 & $\begin{array}{l}\text { Cross- } \\
\text { organizational } \\
\text { processes }\end{array}$ & 4.78 \\
\hline 8. & Unified IT-systems & 2 & Unified IT-systems & 4.77 & 8. & Unified IT-systems & 2 & Unified IT-systems & 4.78 \\
\hline 9. & $\begin{array}{ll}\begin{array}{l}\text { Attract } \\
\text { customers }\end{array} & \text { new } \\
\end{array}$ & 1 & $\begin{array}{ll}\begin{array}{l}\text { Attract } \\
\text { customers }\end{array} & \text { new } \\
\end{array}$ & 3.08 & 9. & $\begin{array}{ll}\begin{array}{l}\text { Attract } \\
\text { customers }\end{array} & \text { new } \\
\end{array}$ & 1 & $\begin{array}{ll}\begin{array}{l}\text { Attract } \\
\text { customers }\end{array} & \text { new } \\
\end{array}$ & 3.09 \\
\hline 10. & Advisory services & 1 & Advisory services & 3.08 & 10. & Advisory services & 1 & Advisory services & 3.09 \\
\hline \multicolumn{5}{|l|}{2010} & \multicolumn{5}{|l|}{2011} \\
\hline 1. & $\begin{array}{l}\text { One operating } \\
\text { model }\end{array}$ & 9 & $\begin{array}{l}\text { One operating } \\
\text { model }\end{array}$ & 13.62 & 1. & $\begin{array}{l}\text { Increasing } \\
\text { business with } \\
\text { existing customers }\end{array}$ & 9 & $\begin{array}{l}\text { Increasing } \\
\text { business with } \\
\text { existing customers }\end{array}$ & 13.45 \\
\hline 2. & $\begin{array}{l}\text { Increasing } \\
\text { business with } \\
\text { existing customers }\end{array}$ & 9 & $\begin{array}{l}\text { Increasing } \\
\text { business with } \\
\text { existing customers }\end{array}$ & 13.13 & 2. & Profit orientation & 7 & $\begin{array}{l}\text { A multi-channel } \\
\text { distribution } \\
\text { network }\end{array}$ & 10.62 \\
\hline 3. & $\begin{array}{l}\text { Operational } \\
\text { efficiency }\end{array}$ & 5 & $\begin{array}{l}\text { A multi-channel } \\
\text { distribution } \\
\text { network }\end{array}$ & 9.35 & 3. & $\begin{array}{l}\text { A multi-channel } \\
\text { distribution } \\
\text { network }\end{array}$ & 6 & Profit orientation & 10.54 \\
\hline 4. & Profit orientation & 5 & $\begin{array}{l}\text { Operational } \\
\text { efficiency }\end{array}$ & 9.13 & 4. & $\begin{array}{ll}\begin{array}{l}\text { One } \\
\text { model }\end{array} & \text { operating } \\
\end{array}$ & 6 & $\begin{array}{ll}\begin{array}{l}\text { One } \\
\text { model }\end{array} & \text { operating } \\
\end{array}$ & 9.54 \\
\hline 5. & $\begin{array}{l}\text { A multi-channel } \\
\text { distribution } \\
\text { network } \\
\end{array}$ & 4 & Profit orientation & 7.92 & 5. & $\begin{array}{l}\text { Operational } \\
\text { efficiency }\end{array}$ & 5 & $\begin{array}{l}\text { Operational } \\
\text { efficiency }\end{array}$ & 9.35 \\
\hline 6. & $\begin{array}{l}\text { A focus on the } \\
\text { Nordic region as } \\
\text { well as new } \\
\text { European markets }\end{array}$ & 3 & $\begin{array}{l}\text { A focus on the } \\
\text { Nordic region as } \\
\text { well as new } \\
\text { European markets }\end{array}$ & 7.62 & 6. & $\begin{array}{l}\text { A focus on the } \\
\text { Nordic region as } \\
\text { well as new } \\
\text { European markets }\end{array}$ & 4 & $\begin{array}{l}\text { A focus on the } \\
\text { Nordic region as } \\
\text { well as new } \\
\text { European markets }\end{array}$ & 8.62 \\
\hline 7. & $\begin{array}{l}\text { Cross- } \\
\text { organizational } \\
\text { processes }\end{array}$ & 2 & $\begin{array}{l}\text { Cross- } \\
\text { organizational } \\
\text { processes }\end{array}$ & 4.92 & 7. & $\begin{array}{l}\text { Relationship } \\
\text { banking }\end{array}$ & 2 & $\begin{array}{l}\text { Relationship } \\
\text { banking }\end{array}$ & 5.81 \\
\hline 8. & Unified IT-systems & 2 & Unified IT-systems & 4.92 & 8. & Social media & 2 & Social media & 5.54 \\
\hline 9. & $\begin{array}{l}\begin{array}{l}\text { Attract } \\
\text { customers }\end{array} \text { new } \\
\end{array}$ & 1 & $\begin{array}{l}\text { Attract new } \\
\text { customers }\end{array}$ & 2.94 & 9. & $\begin{array}{l}\text { Cross- } \\
\text { organizational } \\
\text { processes }\end{array}$ & 2 & $\begin{array}{l}\text { Cross- } \\
\text { organizational } \\
\text { processes }\end{array}$ & 4.45 \\
\hline 10. & Advisory services & 1 & Advisory services & 2.94 & 10. & Unified IT-systems & 2 & Unified IT-systems & 4.45 \\
\hline
\end{tabular}


The organizational-system map shows how Nordea's strategic position is comprised of a set of tailored activities designed to deliver it. The organizational-system map creates one way to examine and strengthen strategic fit. According to Porter (1996) there are some key questions in the process: Is each activity consistent with the overall positioning? Are there ways to strengthen how different elements and groups of elements reinforce one another? Could changes in one element eliminate the need to perform others?

\subsection{Nordea's organizational system in $\mathbf{2 0 0 0}$}

Figure 7 shows Nordea's organizational system in 2000. I identified four core elements in Nordea's organizational system.

Nordea 2000

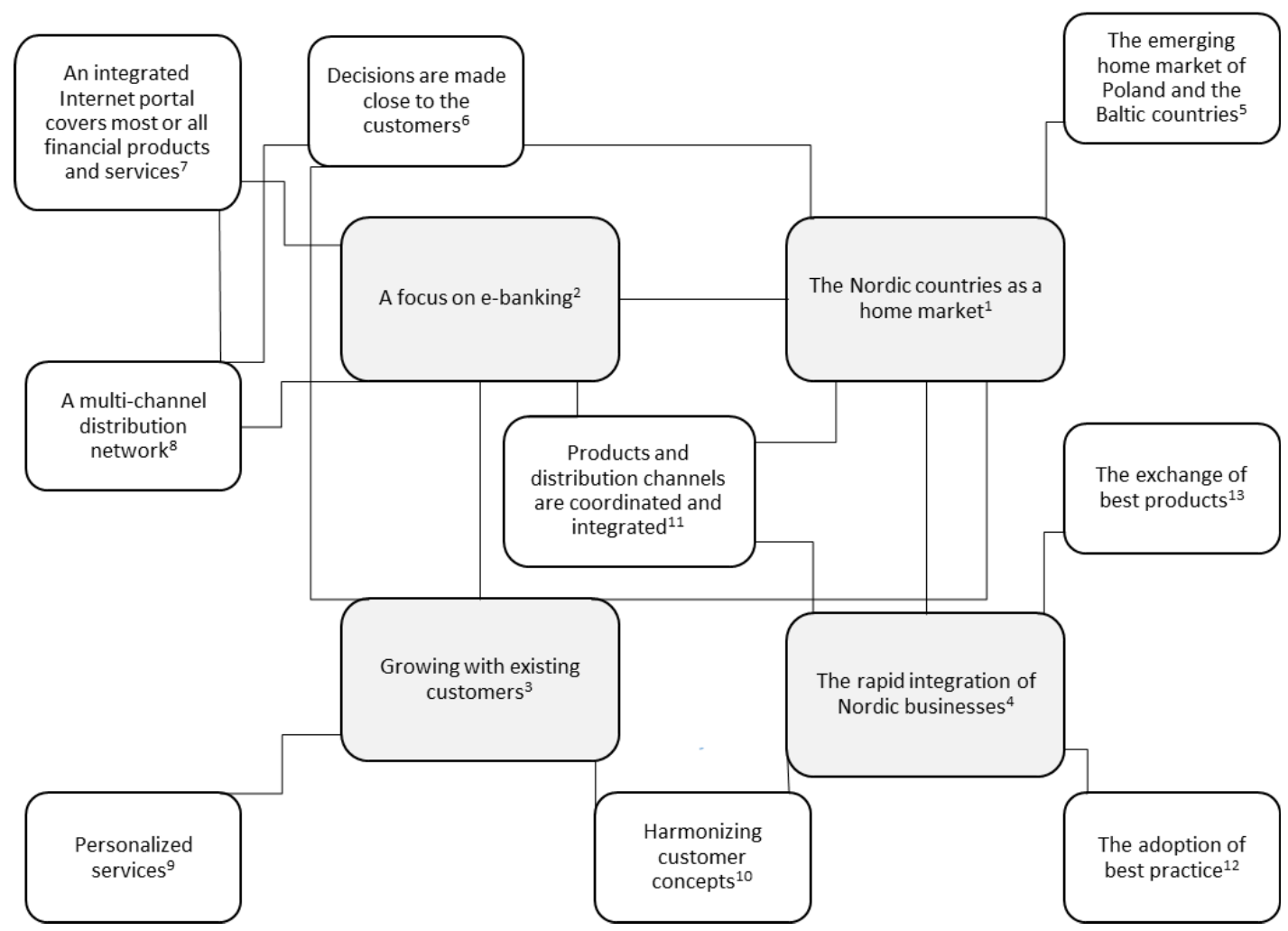

Figure 7: Nordea's organizational system in 2000 
The first core element in Nordea's organizational system was considering "the Nordic countries as a home market" for the bank. An elaborating element for it was that "the emerging home market of Poland and the Baltic countries."

The merging banks forming Nordea in the early 2000s shared the vision of becoming the leading financial services group in the Nordic and Baltic Sea region. The bank's presence was continuously expanding in Lithuania, Latvia, and Estonia.during the studied period. Also Nordea had about 1200 employees in two banks in Poland and two insurance companies. The CEO and President of the bank, Hans Dahlborg, pointed out in Nordea's Annual Report 2000 that in less than four years, Nordea's vision has been realized (Nordea Annual Report 2000: 6).

The interviewees also reinforced that fact the original background for the creation of Nordea was the Nordic dimension and a clear target was creating a Nordic bank that would have a strong market position in all four Nordic countries (board member, 2014; top managers, 2014, 2015).

"The Nordic countries as a home market" fulfills the criteria for being a core element. First, it was mentioned several times as an important strategic issue in Nordea's annual reports (Criterion 1). Second, it was logically connected three other core elements ("a focus on e-banking," "growing with existing customers," and "rapid integration of Nordic businesses"), thus it had high interdependency (Criterion 2). Third, it is an element that interacts with six other organizational elements (Criterion 3).

The second elaborating element for the first core element in Nordea's organizational system was the principle that "decisions are made close to the customers." Although Nordea operates in many different countries, it emphasized local decision-making. According to the interviewees, local decision-making was a key element from the beginning in Nordea's business strategy. The main principle was local decisionmaking, and a centralized credit policy and risk management (interview with top managers, 2014, 2015). 
Nordea's second core element was "a focus on e-banking." This core element is mentioned as strategically important in the bank's strategy statement. The bank especially focused on having a top world ranking in e-based financial solutions (Nordea Annual Report 2000: 3). E-banking services were a way to help increase customer satisfaction. Thorleif Krarup, President and CEO (2001-2002) of Nordea, pointed out that the e-revolution is fundamentally changing the financial services industry with new products and services, and by lowering barriers for new competitors to enter into the business, and by increased opportunities for customers to change bank or insurance company (Nordea Annual Report 2000: 11). Nordea was granted a global award for the "Best Online Business Strategy" by the leading global banking magazine The Banker (Nordea Annual Report 2000: 8).

"A focus on e-banking" fulfills the criteria for being a core element. First, it was mentioned several times as an important strategic issue in Nordea's annual reports (Criterion 1). Second, it was logically connected to two other core elements ("the Nordic countries as a home market" and "growing with existing customers"), thus having high interdependence (Criterion 2). Third, it is an element that interacts with five other organizational elements (Criterion 3 ).

The first elaborating element for the second core element was that an integrated internet portal covers most (or all) financial products and services. This is important because then e-banking helps to increase both customer satisfaction and internal productivity (Nordea Annual Report 2000: 8, 11). The second elaborating element was the bank's multi-channel distribution network. This elaborating element combines e-banking and a traditional branch network. According to the interviewees Nordea had a lot of focus on e-banking in the early 2000s because one of its premerger banks (Merita Bank) had been a forerunner in e-banking and they saw a lot of growth potential in e-banking. But they also realized that other distribution channels are needed in the future (top managers, 2014, 2015). In the early 2000s "IT hype" was generally going on and this also had an impact on the bank's strategic choices (board member, 2014).

The third core element for Nordea was the principle of "growing with existing customers." It was the first priority in the bank's business strategy and then 
mentioned as an important issue in the bank's strategy statement. This strategic issue was logically connected to Nordea's business operations in a substantial way (Criterion 2). The third core element interacted with many current or future organizational elements (Criterion 3) and this was mentioned as an important strategic issue many times in Nordea's annual reports (Criterion 1).

A focus on e-banking supports the third core element. The bank pointed out that the Nordic investments in the Solo concept were an example of this focus. When the target was to grow with its existing customers, harmonizing customer concepts supported this target and it is an elaborating element for the third core element (Nordea Annual Report 2000: 10). Other elaborating elements for the third core element were "personalized services" and "decisions are made close to the customers."

Nordea's fourth core element was "the rapid integration of Nordic businesses." This core element is logically connected to Nordea's business operations in a substantial way, which is one of criteria to qualify as a core element (Criterion 2). After the merger between MeritaNordbanken and Unidanmark in 2000, it was logical to work towards rapid integration because it involved identified synergies valued at EUR 200 million and the delivery of these synergies would have a positive impact to the bank's performance (Nordea Annual Report 2000: 9). This was also a strategic issue for the bank, therefore it is highlighted many times in the annual report (Criterion 1). The fourth core element was an element that interacted with five other elements (Criterion 3).

I identified four elaborating elements for the fourth core element. The first elaborating element is "the exchange of best products" (Nordea Annual Report 2000: 7). To provide the best products for all Nordea's customers more compact internal integration was needed. The second one is "the adoption of best practice" (Nordea Annual Report 2000: 10). This also means tighter internal co-operation. The third elaborating element is "harmonizing customer concepts" (Nordea Annual Report 2000: 10) and the fourth one is "coordinated and integrated products and distribution channels" (Nordea Annual Report 2000: 7). By harmonizing customer concepts, and having integrated products and distribution channels, the bank targeted being more 
similar (from a customer's point of view) in all the geographic areas in which the bank had operations.

\subsection{Nordea's organizational system in 2001}

Figure 8 shows Nordea's organizational system in 2001. I identified four core elements in Nordea's organizational system.

Nordea 2001

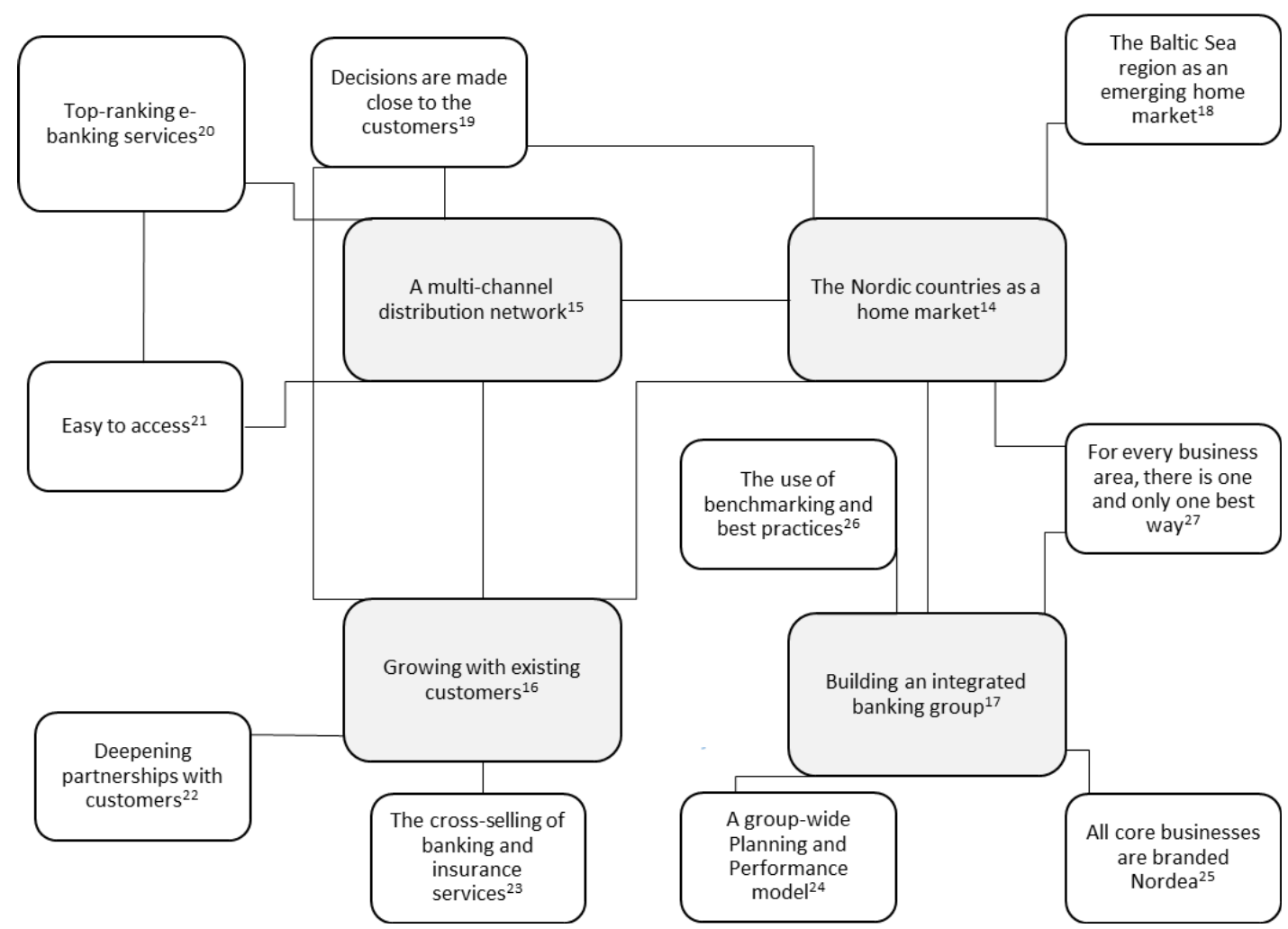

Figure 8: Nordea's organizational system 2001

In 2001 the first core element of Nordea continued to be similar to the previous core element "the Nordic countries as a home market," but an elaborating element for it had shaped it into a new form. "The Baltic Sea region as an emerging home market" 
had replaced the earlier formulation "the emerging home market was Poland and the Baltic countries." In fact the change was more semantic.

The second elaborating element for the first core element was that "decisions are made close to the customer." After the merging process between four Nordic banks, Nordea tried to emphasize that it was still close its customers, although its home market was now the whole Nordic area. The third elaborating element for it was the principle that "for every business area, there is one and only one best way" (to operate). This elaborating element emphasized that the bank's basic idea was to share and exchange Nordic ideas (Nordea Annual Report 2001: 6). This element was also an elaborating element for the second core element.

The second core element was an element that was earlier an elaborating element; "a multi-channel distribution network." It had replaced the previous core element "a focus on e-banking." This was the shaping process affecting the core element. In 2000 "a focus on e-banking" was one of the core elements and "a multi-channel distribution network" was an elaborating element for it. But in 2001 the bank clearly put more focus on "a multi-channel distribution network" in its business strategy and "top-ranking e-banking services" were an elaborating element for it. Other elaborating elements for the second core element were "easy to access" and "decisions are made close to the customers."

According to the interviewees the core element "a focus on e-banking" was shaped into a new shape, "a multi-channel distribution network," because e-banking was already established and it had a growing amount of customers but the branch network was still an important distribution channel (top manager, 2015). A part of Nordea's top management did not believe that e-banking would be a single distribution channel for the bank in the future (top manager, 2014) and this aspect was supported the process of transforming the existing core element "a focus on ebanking" into a new shape, "a multi-channel distribution network." One of the interviewees used the word "shaping" when he described the development process of a multi-channel distribution network (top manager, 2015). 
As a core element "a multi-channel distribution network" fulfills the criteria for being as a core element very well. It has been mentioned as important strategic issue in Nordea's annual reports (Criterion 1), it is logically connected to business operations (how to deliver banking products and services) in a substantial way (Criterion 2), and it is an element that interacts with five other organizational elements (Criterion 3 ).

"Growing with existing customers" was the third core element. This strategic issue was logically connected to Nordea's business operations in a substantial way, which is one of criteria to qualify as a core element. Based on Nordea's regional leadership, position, and size, it had the goal to be the number one or number two, or to show superior growth in every market and product area in which it chooses to compete (Nordea Annual Report 2001: 12). There were two elaborating elements for the third core element: "a deepening partnership with customers" and "the cross-selling of banking and insurance services." Both of these reinforced the core element "growing with existing customers."

The fourth core element was no longer "the rapid integration of Nordic businesses," as the bank focused on "building an integrated banking group." This strategic issue was mentioned many times in Nordea's annual reports (Criterion 1). This new shape of the core element logically connected to Nordea's business operations in a substantial way (Criterion 2), and it was an element that had a high interdependency with other current organizational elements (Criterion 3).

The fourth core element had four elaborating elements. An elaborating element for the fourth core element was the principle that "all core business are branded Nordea." A group-wide culture change program ("From Words to Action") for the joint Nordea values was implemented (Nordea Annual Report 2001: 11). "For every business there is one and only one best way" was an elaborating element for the second core element. Another elaborating element for it was "the use of benchmarking and best practices." I also identified an elaborating element that was "a group-wide planning and performance model".

Although "building an integrated banking group" was a core element, the integration process did not develop well in 2001 and 2002. Thorleif Krarup was the President 
and CEO of Nordea from 2001 to 2002 and he could not implement the strategy or integration process well enough (the integration process was especially a problem) and therefore his period as CEO was short (board member, 2014; top manager, 2014).

\subsection{Nordea's organizational system in 2002}

Figure 9 shows Nordea's organizational system in 2002. I identified six core elements in Nordea's organizational system.

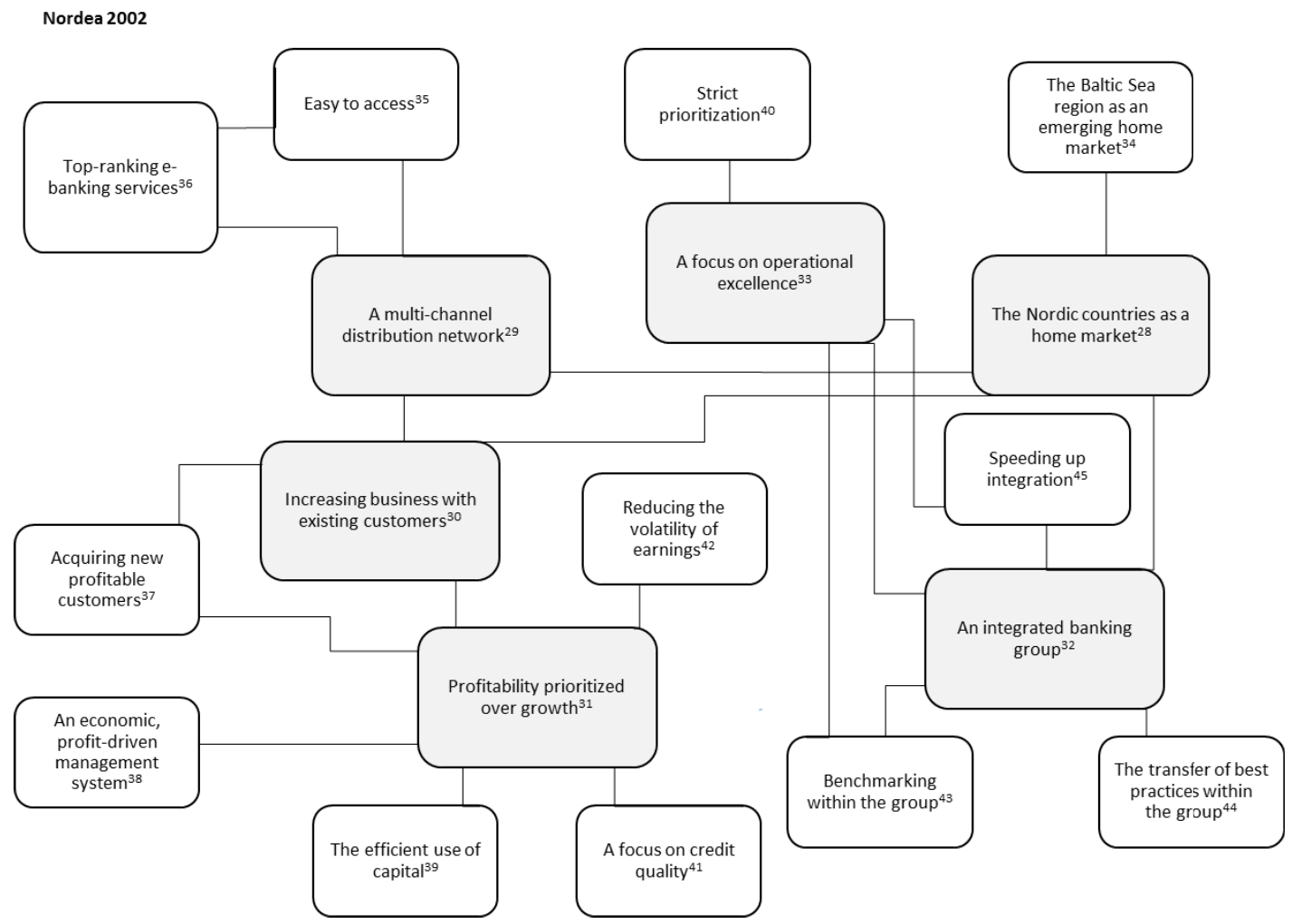

Figure 9: Nordea's Organizational System 2002

In 2002 the first core element of Nordea continued to be "the Nordic countries as a home market," and "the Baltic Sea region as an emerging home market" continued to be an elaborating element for it. 
The second core element for Nordea continued to be "a multi-channel distribution network." The second core element had the same two elaborating elements as earlier: "top-ranking e-banking services" and "easy to access."

The third core element of Nordea's activity system was elaborated into a new shape, "increasing business with existing customers." Earlier the form of the core element was the strategic principle of "growing with its customers." Nordea pointed out in its strategy statement that the customer base is Nordea's main asset and that there was significant business potential in this customer base (Nordea Annual Review 2002: 18). The bank's new President and CEO, Lars G. Nordström (2002-2007), sharpened the strategy and put more focus on increasing the share of wallet of existing customers (Nordea Annual Review 2002: 19). This core element fulfills the criteria for a core element very well because it was connected to Nordea's business operations in a substantial way (Criterion 2). It was mentioned many times as an important strategic issue in Nordea's annual reports (Criterion 1) and this core element is an element that interacts with five other organizational elements (Criterion 3). There was one elaborating element for the third core element: "acquiring new profitable customers." The principle of "acquiring new profitable customers" enables a larger growth base for Nordea's business.

The fourth core element was the principle to be "an integrated banking group." Lars G. Nordström pointed out in his letter to shareholders that the bank is on its way to integrating and unifying the organization in cross-Nordic business areas and group functions (Nordea Annual Review 2002: 10). When the previous President and CEO, Thorleif Krarup (2001-2002), had to step down and Nordström started, Nordström wanted to see more speed in the integration process and the delivery of potential synergies (top manager, 2015).

It was the new shape of the previous form of the core element, "building an integrated banking group." The new formulation was "an integrated banking group," which really meant speeding up integration and unification. The fourth core element was logically connected to Nordea's business operations in a substantial way (Criterion 2). It was also mentioned as an important strategic issue many times in 
Nordea's annual reports (Criterion 1) and it was an element that interacts with many current or future organizational elements (Criterion 3).

There were three elaborating elements for the fourth core element: "speed-up integration," "benchmarking within the group," and "the transfer of best practices within the group."

"A focus on operational excellence" was the fifth core element in Nordea's organizational system. Nordea pointed out in the strategy statement that operational excellence is one of the key elements in its strategy. Integration projects were reprioritized and IT development costs had been capped at $80 \%$ of their 2002 level. The significant potential for continued benchmarking and the transfer of best practices within the group were the basis for continuous improvements (Nordea Annual Review 2002: 19). Lars G. Nordström emphasized operational excellence in his leadership (top manager, 2015).

The fifth core element was mentioned as an important strategic issue many times in Nordea's annual reports (Criterion 1). It was logically connected to Nordea's business operations in a substantial way (Criterion 2). The fifth core element is an element that interacts with five other organizational elements (Criterion 3 ).

There were three elaborating elements for the fifth core element: "strict prioritization," "speed-up integration," and "benchmarking within the group."

The sixth core element was "profitability prioritized over growth." It was a totally new element in Nordea's activity system. Lars G. Nordström emphasized that profitability should be prioritized over growth and this principle was reflecting in the way in which Nordea allocates capital (Nordea Annual Review 2002: 20). Nordström emphasized the role of capital management in Nordea's operations (top manager, 2015). The sixth core element was connected to Nordea's strategy in a substantial way (Criterion 2 ) and therefore it fulfills the criteria for a core element. The sixth core element was mentioned as an important strategic issue many times in Nordea's annual reports (Criterion 1), and it was an element that interacts with five other organizational elements (Criterion 3). 
"The efficient use of capital" was an elaborating element for the sixth core element. This elaborating element was linked to the way in which the bank allocates its capital for growth. In 2002 the bank had the ongoing implementation of "an economic profitdriven management system" as a framework to enhance capital efficiency (Nordea Annual Review 2002: 9). “Acquiring new profitable customers" was also one elaborating element for the sixth core element. The last elaborating element was "a focus on credit quality."

\subsection{Nordea's organizational system in $\mathbf{2 0 0 3}$}

Figure 10 shows Nordea's organizational system in 2003. I identified six core elements in Nordea's organizational system.

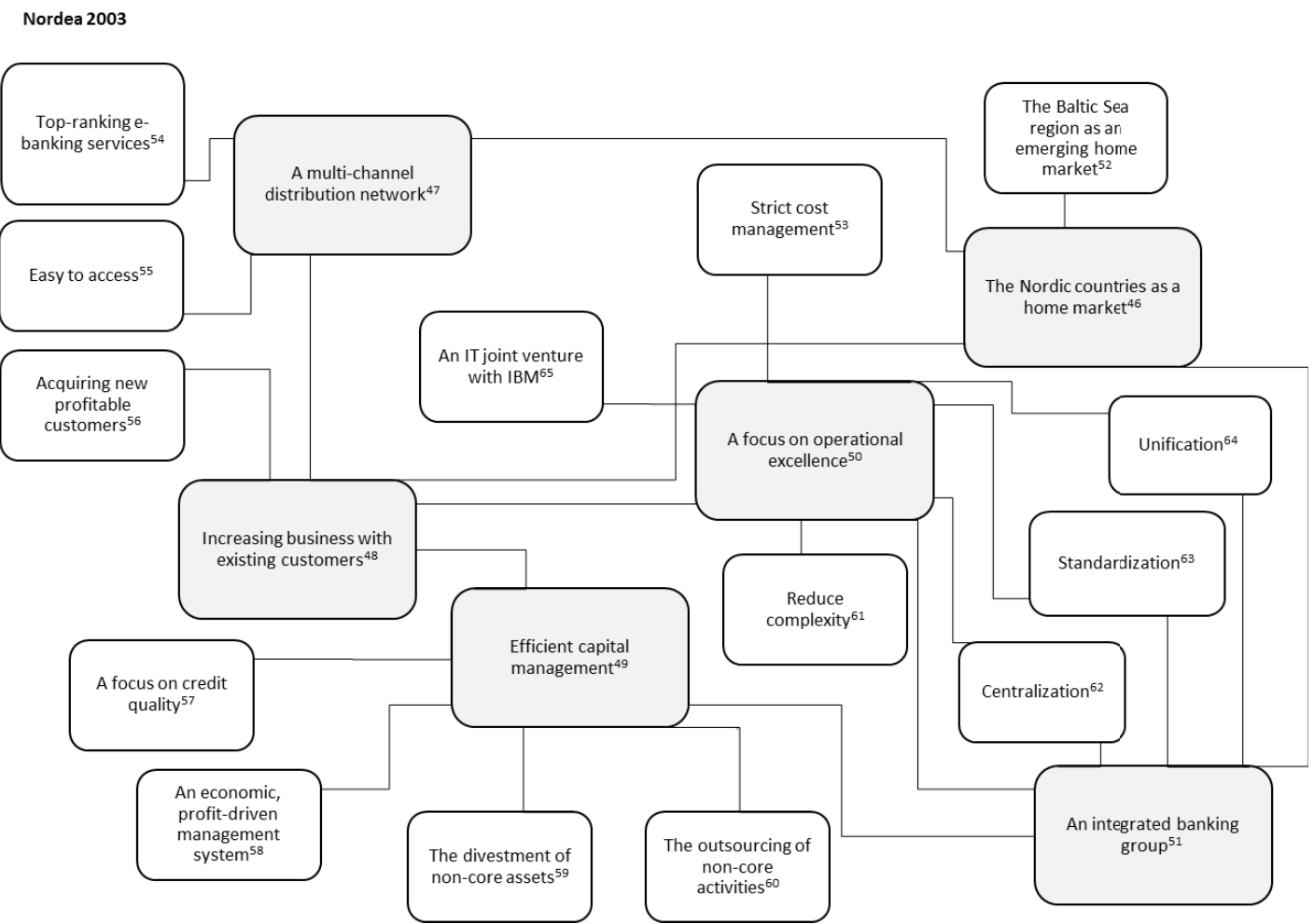

Figure 10: Nordea's Organizational System in 2003 
In 2003 the first core element of Nordea continued to be "the Nordic countries as a home market," and "the Baltic Sea region as an emerging home market" continued to be an elaborating element for it.

The second core element for Nordea continued to be "a multi-channel distribution network." The second core element had the same two elaborating elements as earlier: "top-ranking e-banking services" and "easy to access." Ease of access and use was an important element in the process of increasing the penetration rate of ebanking services.

"Increasing business with existing customers" continued to be the third core element in Nordea's activity system. It had one elaborating element, which was "acquiring new profitable customers."

The fourth core element for Nordea continued to be "an integrated banking group." It had three new elaborating elements: unification, standardization, and centralization. The background for these elaborating elements were that continuous improvements were to drive cost management in the large customer organization, while transformation and changes aiming at unification, standardization, and centralization were to characterize the cost control efforts in the organization (Nordea Annual Review 2003: 17).

"A focus on operational excellence" continued to be the fifth core element in Nordea's activity system. This core element had six elaborating elements. One of them, "strict cost management," was the same as one year earlier. Other elaborating elements were: unification, standardization, centralization, an IT joint venture with IBM, and the target of reducing complexity. Lars G. Nordström, President and CEO (2002-2007), pointed out in his letter to shareholders that one of major initiatives includes a substantial reduction of IT development costs and the consolidation of IT production in a joint venture with IBM (Nordea Annual Review 2003: 8). It was a question about IT mainframe integration between branches in different countries. It was a brave move by the bank (top manager, 2015). The IT joint venture with IBM was an important elaborating element for the fifth core element. 
"Efficient capital management" was the sixth core element in Nordea's activity system. It was the new shape of a previous core element "Profitability prioritized over growth." Lars G. Nordström, emphasized efficient capital management in his leadership (top manager, 2015). It meant more focus on core business and the bank made divestments of non-core assets. Nordea's capital efficiency was strengthened through divestments of real estate and other non-core assets, changed business models, the growth of off-balance-sheet business, and the implementation of an economic capital and economic profit framework (Nordea Annual Review 2003: 7). This core element was logically connected to Nordea's business operations in a substantial way (Criterion 2). It was mentioned as an important strategic issue many times in Nordea's annual reports (Criterion 1) and it was an element that interacts with six other organizational elements (Criterion 3 ).

There were four elaborating elements for the sixth core element. One of them was an elaborating element for a previous core element ("profitability prioritized over growth") and it was "an economic profit-driven management system." New elaborating elements were "the divestment of non-core assets," "the outsourcing of non-core activities," and "a focus on credit quality." Lars G. Nordström emphasized these issues in his letter to shareholders after the year 2003 (Nordea Annual Review 2003: 7). These elaborating elements provide a more efficient use of capital for the bank.

\subsection{Nordea's organizational system in 2004}

See Figure 11 below, which shows Nordea's organizational system in 2004. I identified six core elements in Nordea's organizational system.

In 2004 the first core element of Nordea continued to be "the Nordic countries as a home market," and "the Baltic Sea region as an emerging home market" continued to be an elaborating element for it.

The second core element for Nordea continued to be "a multi-channel distribution network." The second core element had the same two elaborating elements as earlier: "top-ranking e-banking services" and "easy to access." 


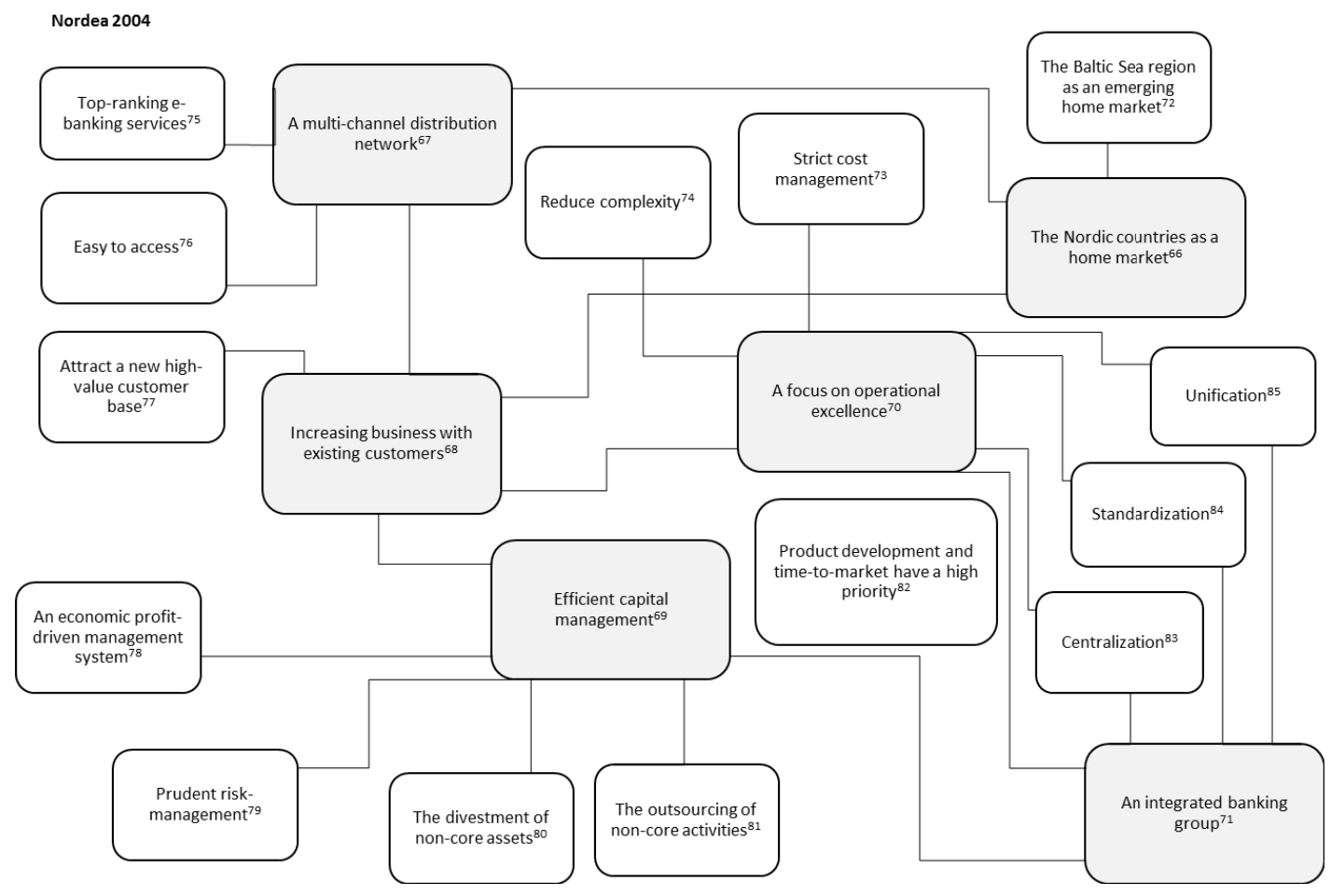

Figure 11: Nordea's Organizational System in 2004

"Increasing business with existing customers" continued to be the third core element in Nordea's activity system. It had one elaborating element, which was a new formulation of the previous elaborating element. This elaborating element was to "attract a new high-value customer base." This aim was pointed out in Nordea's strategy statement that stated that the bank was aiming to attract and expand its high-value customer base (Nordea Annual Review 2004: 17).

The fourth core element for Nordea continued to be "an integrated banking group." It had three elaborating elements, which were the same as one year earlier: unification, standardization, and centralization. The background for these elaborating elements was that "these efforts also contribute to undoing the inherent complexities following a history of mergers and acquisitions" (Nordea Annual Review 2004: 17). 
"A focus on operational excellence" continued to be the fifth core element in Nordea's activity system. There were six elaborating elements for this core element and five of them were the same as one year earlier: unification, standardization, centralization, strict cost management, and the target of reducing complexity. The new elaborating element was the principle that "product development and time-tomarket have a high priority." Lars G. Nordström highlighted the need to speed-up product innovation (Nordea Annual Review 2004: 6).

"Efficient capital management" continued to be the sixth core element in the activity system of Nordea. There were three elaborating elements for this core element. Two of them were same as one year earlier: "the divestment of non-core assets" and "the outsourcing of non-core activities." The new elaborating element was "prudent risk management." Prudent risk management improves the efficient use of capital.

\subsection{Nordea's organizational system in 2005}

See Figure 12 below, which depicts Nordea's organizational system in 2005 . I identified six core elements in Nordea's organizational system.

In 2005 the first core element in Nordea continued to be "the Nordic countries as a home market," and "the Baltic Sea region as an emerging home market" continued to be an elaborating element for it.

The second core element for Nordea continued to be "a multi-channel distribution network." There were two elaborating elements that were the same as before for this core element: "top-ranking e-banking services" and "easy to access." Nordea emphasized convenient and easy access through multi-channel availability in its customer service (Nordea Annual Report 2005: 15). Nordea pointed out in its strategy statement that it was developing the accessibility of the bank end, thereby enhancing convenience for the customers (Nordea Annual Report 2005: 11). 


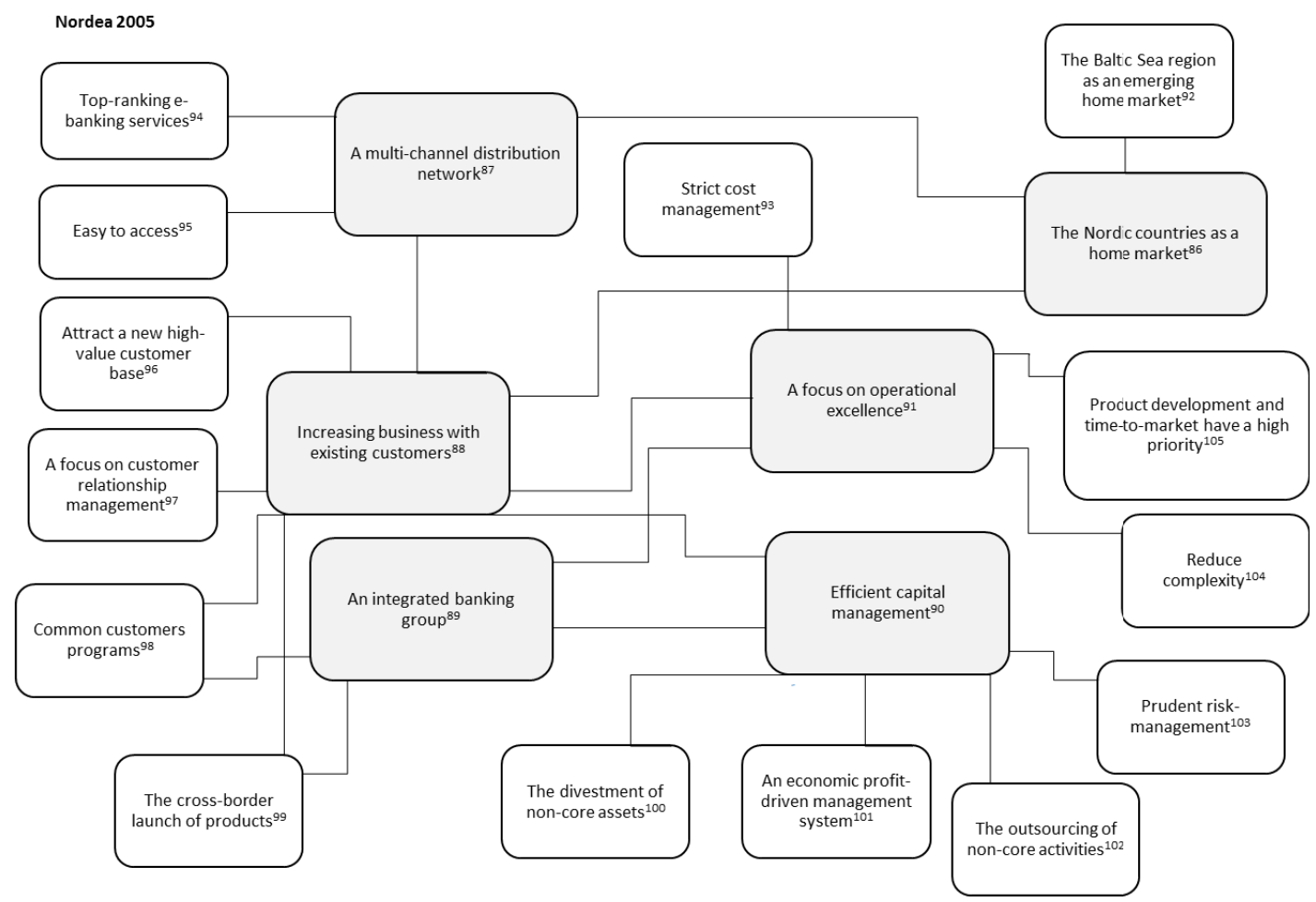

Figure 12: Nordea's Organizational System 2005

"Increasing business with existing customers" continued to be the third core element in Nordea's activity system. There were four elaborating elements for this core element. One of them was the same as earlier: "attract a new high-value customer base." There were also three new elaborating elements: "common customer programs," "the cross-border launch of products," and "a focus on customer relationship management." Nordea saw that its large customer base was leveraged by increasing the number of customers in the most profitable segments (Nordea Annual Report 2005: 11).

The fourth core element for Nordea continued to be "an integrated banking group." It had two elaborating elements that were new elements: "common customer programs" and "the cross-border launch of products". 
"A focus on operational excellence" continued to be the fifth core element in Nordea's organizational system. There were three elaborating elements for this core element, and all of them had featured one year earlier: strict cost management, the target of reducing complexity, and the principle that product development and timeto-market have high priority. Nordea emphasized in their strategy statement that ensuring operational excellence, strict cost management, and reduced complexity were top priorities all through the bank. Also product development, innovativeness, and time-to-market had a high priority (Nordea Annual Report 2005: 11).

"Efficient capital management" continued to be the sixth core element in the activity system of Nordea. There were three elaborating elements for this core element. All of them were the same as one year earlier: "the divestment of non-core assets," "the outsourcing of non-core activities," and "prudent risk management."

\subsection{Nordea's organizational system in 2006}

See Figure 13 below, which depicts Nordea's organizational system in 2006. I identified six core elements in Nordea's organizational system.

In 2006 the first core element of Nordea continued to be "the Nordic countries as a home market," and "the Baltic Sea region as an emerging home market" continued to be an elaborating element for it.

The second core element for Nordea continued to be "a multi-channel distribution network." The second core element had one elaborating element that was the same as earlier: "easy to access." Convenient and easy access through multi-channel availability continued to be a key element in the bank's value proposition (Nordea Annual Report 2006: 19). Nordea highlighted that the bank operates a multi-access strategy, making it possible for customers to access the bank when and how it suits them (Nordea Annual Report 2006: 21). 


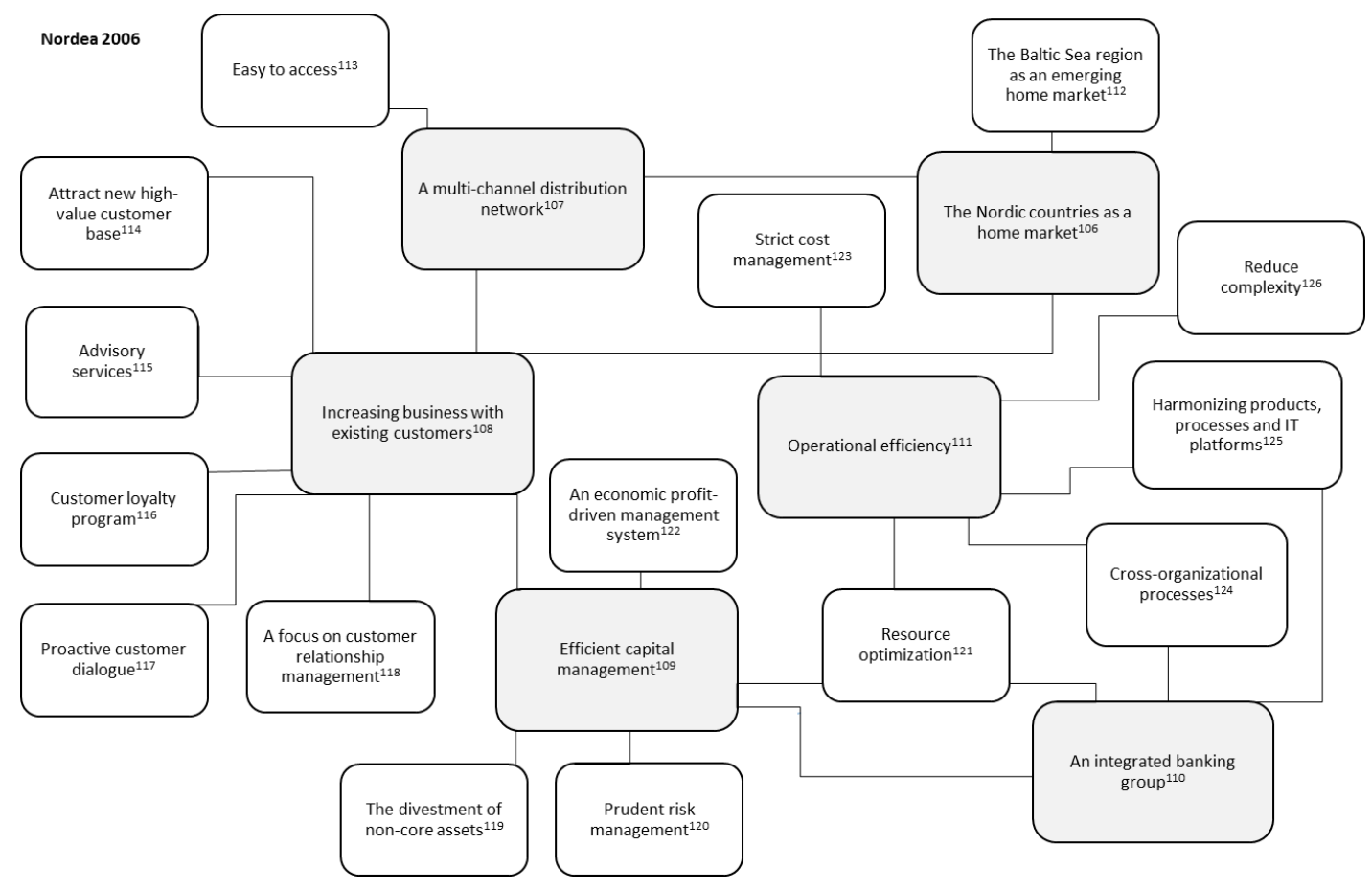

Figure 13: Nordea's Organizational System in 2006

"Increasing business with existing customers" continued to be the third core element in Nordea's activity system. There were five elaborating elements for this core element. Two of them were the same as one year earlier: "attract a new high-value customer base" and "a focus on customer relationship management." There were also three new elaborating elements for this core element: "advisory services," "a customer loyalty program," and "proactive customer dialogue." The bank thought that fair and transparent market pricing would enhance customer loyalty and relationships (Nordea Annual Report 2006: 19).

The fourth core element for Nordea continued to be "an integrated banking group." It had two elaborating elements that were new: "cross-organizational processes" and "harmonizing products, processes, and IT platforms." 
The fifth core element of Nordea's activity system was shaped into the new form "operational efficiency." The previous form of the core element was "a focus on operational excellence." There were five elaborating elements for the fourth core element. Two of them were the same as one year earlier: "strict cost management" and "reduce complexity." New elaborating elements were "harmonizing products, processes, and IT platforms," "cross-organizational processes," and "resource optimization." Nordea emphasized that key areas for further operational efficiency were a number of lean banking and cost initiatives, and the release of sales capacity in the branches (Nordea Annual Report 2006: 11).

"Efficient capital management" continued to be the sixth core element in the activity system of Nordea. There were four elaborating elements for this core element. Three of them were the same as one year earlier: "prudent risk management," "the divestment of non-core assets," and "an economic profit-driven management system." "Resource optimization" was a new elaborating element for this core element.

\subsection{Nordea's organizational system in $\mathbf{2 0 0 7}$}

See Figure 14 below, which shows Nordea's organizational system in 2007. I identified six core elements in Nordea's organizational system.

The first core element of the Nordea's activity system was elaborated into a new shape, "a focus on the Nordic region as well as new European markets." Earlier the form of the core element was "the Nordic countries as a home market." It had no elaborating elements. Nordea had new ambitious strategic targets, not least expressed through the bank's goal of doubling the risk-adjusted profit from 2006 to 2013, implying an average annual growth of around 10 per cent (Nordea Annual Report 2007: 4). This ambitious growth target was a key driver leading to Nordea reviewing its geographical focus in the strategy, taking a more aggressive stance, and expanding its home market. 


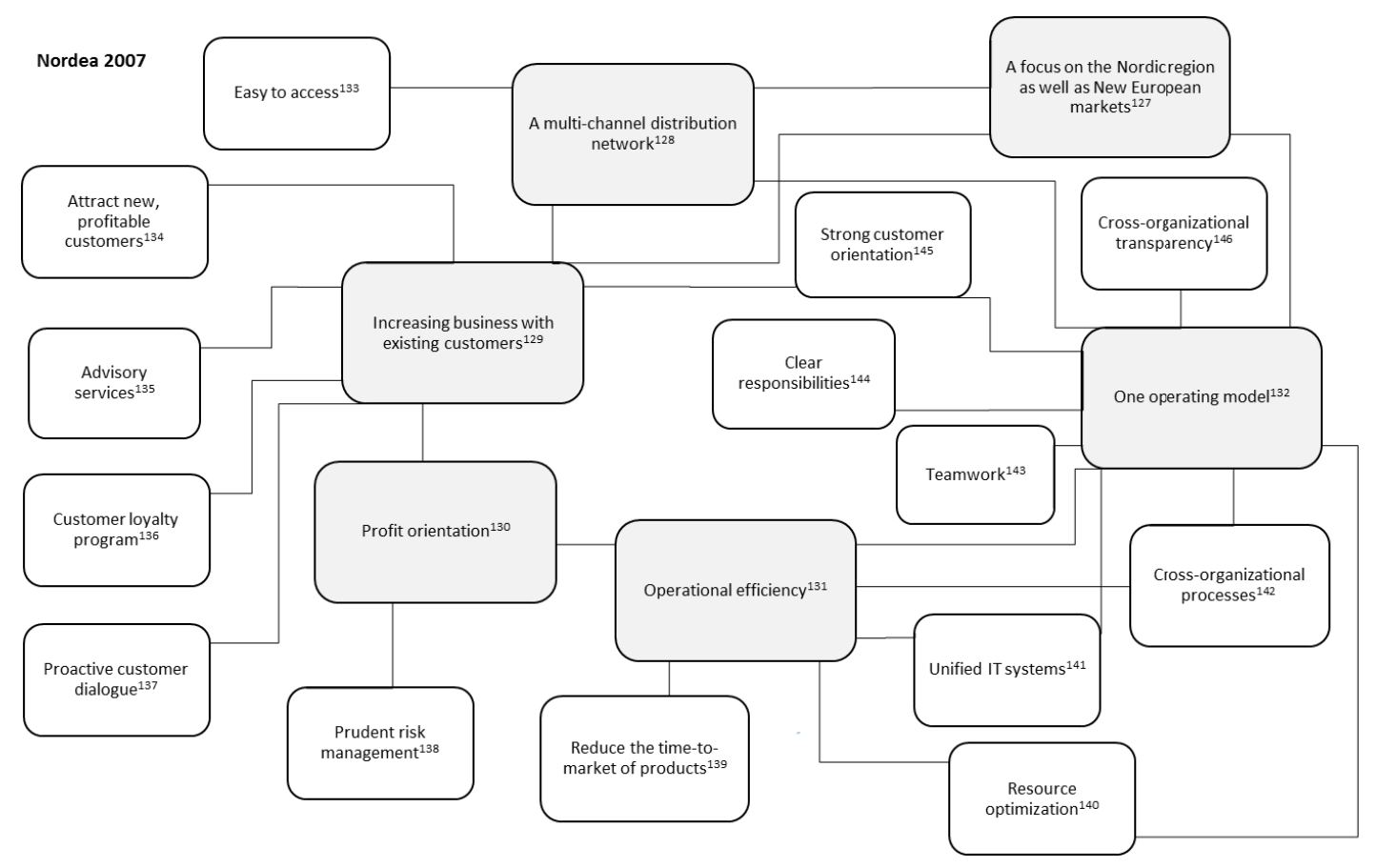

Figure 14: Nordea's Organizational System in 2007

The second core element for Nordea continued to be "a multi-channel distribution network." The second core element had one elaborating element that was the same as earlier: "easy to access."

"Increasing business with existing customers" continued to be the third core element in Nordea's activity system. There were five elaborating elements for this core element; four were the same as one year earlier: "attract new profitable customers," "advisory services," "a customer loyalty program," and "proactive customer dialogue." One elaborating element had been shaped to some extent into a different form; "strong customer orientation."

The fourth core element of the Nordea's activity system was shaped into "one operating model." According to the new President and CEO, Christian Clausen (2007-2015), "one operating model" was a more customer-oriented operating model that covers the entire value chain. In the new organization there were clearly defined 
customer-responsible units, products and processing were organized in units covering the whole value chain, and all other units were organized in accordance with value chain thinking (Nordea Annual Report 2007: 5). The basic idea in thinking of "one operating model" was that it was customer-centric model, wherein the whole of Nordea's organization was working together for good customer service (top manager, 2015).

The fourth core element was mentioned as an important strategic issue in Nordea's annual reports (Criterion 1). It was logically connected to Nordea's business operations (as a way to organize customer service and support functions) in a substantial way (Criterion 2), and it was an element that interacts with ten other organizational elements (Criterion 3).

"Operational efficiency" continued to be the fifth core element in the activity system of Nordea. There were four elaborating elements for this core element. Two of them were the same as one year earlier: "cross-organizational processes" and "resource optimization." The two new elaborating elements were "reduce the time-to-market of products" and "unified IT systems."

The sixth core element of Nordea's activity system was shaped into "profit orientation." Earlier the form of the core element was "efficient capital management." Christian Clausen emphasized that one core element for a great company is a strong profit orientation (Nordea Annual Report 2007: 4). Nordea pointed out in the strategy statement for 2007 that a strong profit orientation was the foundation for generating results and making room for investments in future growth (Nordea Annual Report 2007: 12).

\subsection{Nordea's organizational system in 2008}

Figure 15 shows Nordea's organizational system in 2008. I identified six core elements in Nordea's organizational system.

The first core element continued to be "a focus on the Nordic region as well as new European markets." It had no elaborating elements, but it was connected to three 
other core elements. Nordea's original strategy had gradually been developed to include local customers, but in 2008 Nordea, in addition to its Nordic customers, was targeting the upper segments among household customers and solid medium-sized corporate customers in new European markets and, in addition, in Russia, very large corporate customers. The new European markets include Russia, Poland, and the Baltic countries, Estonia, Latvia, and Lithuania (Nordea Annual Report 2008: 10-11).

The second core element for Nordea continued to be "a multi-channel distribution network." It had no elaborating elements, but it was connected with four other core elements.

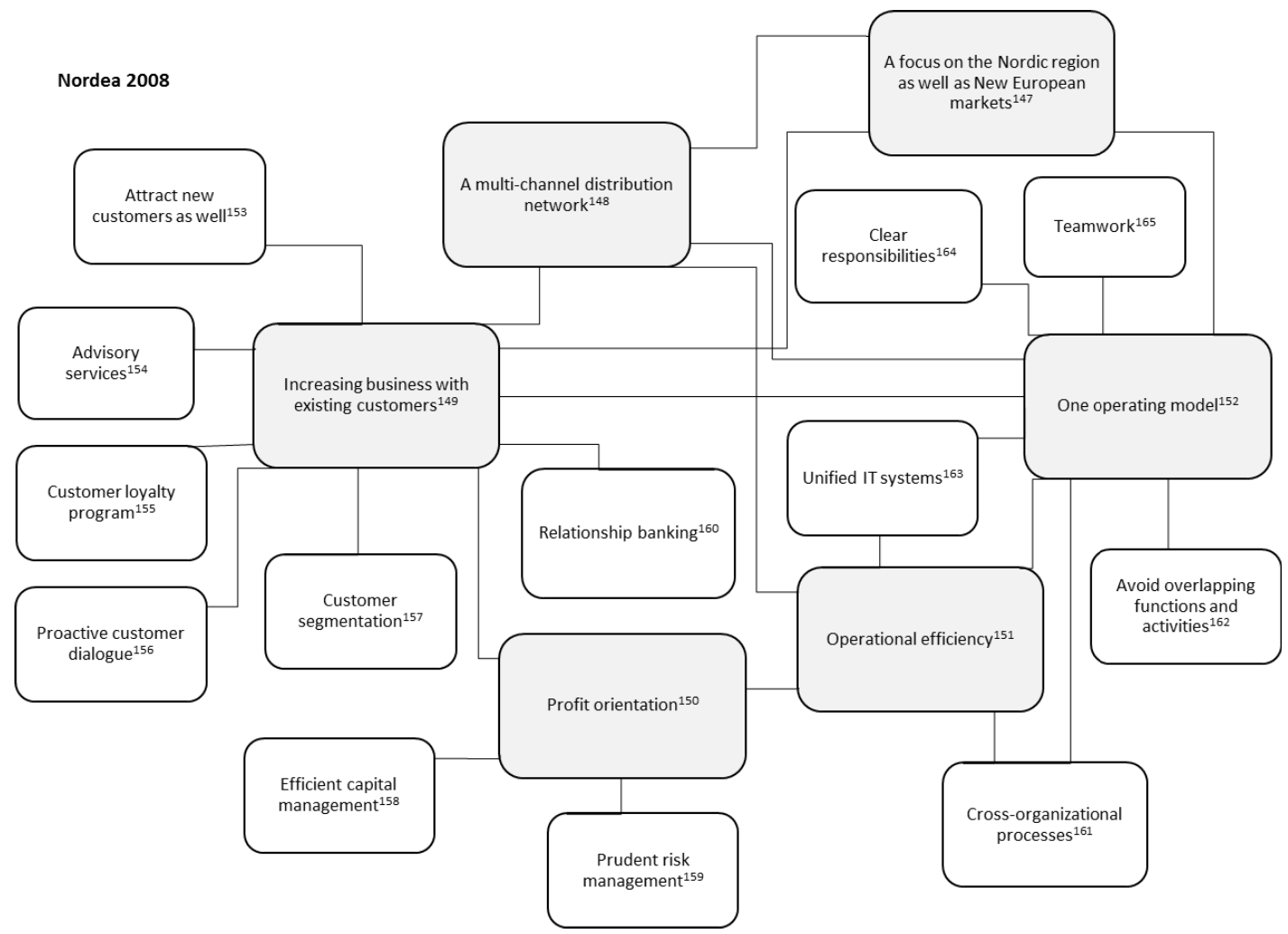

Figure 15: Nordea's Organizational System in 2008

"Increasing business with existing customers" continued to be the third core element in Nordea's activity system. In Christian Clausen's letter to shareholders he 
emphasized that the bank continues to focus on supporting existing core customers and attracting new relationships with customers with solid credit profiles in the Nordic markets (Nordea Annual Report 2008: 7). The household relationship banking strategy is supported by a focused product strategy (Nordea Annual Report 2008: 10). There were six elaborating elements for the third core element, and four of them were the same to the previous year. There were two new elaborating elements for the third core element: "relationship banking" and "customer segmentation." Customer segmentation supports the bank's target to provide the right services and products to the right customers (Nordea Annual Report 2008: 2). Nordea has a clear emphasis on relationship banking with corporate customers and aims at becoming the house bank by combining all the bank's resources and competences with local presence and applying a customer team concept (Nordea Annual Report 2008: 2).

"One operating model" continued to be the fourth core element in Nordea's activity system. There were five elaborating elements for the fourth core element. Four of them were the same as in the previous year. "Avoid overlapping functions and activities" was a new elaborating element for the fourth core element.

"Operational efficiency" continued to be the fifth core element in the activity system of Nordea. There were two elaborating elements for this core element: "crossorganizational process" and "unified IT systems." Both of them were elaborating elements in the previous year.

"Profit orientation" continued to be the sixth core element in the activity system of Nordea. There were two elaborating elements for the sixth core element. One of them was the same as in the previous year and another, "efficient capital management," was a new elaborating element.

\subsection{Nordea's organizational system in 2009}

Figure 16 shows Nordea's organizational system in 2009. I identified six core elements in Nordea's organizational system. 


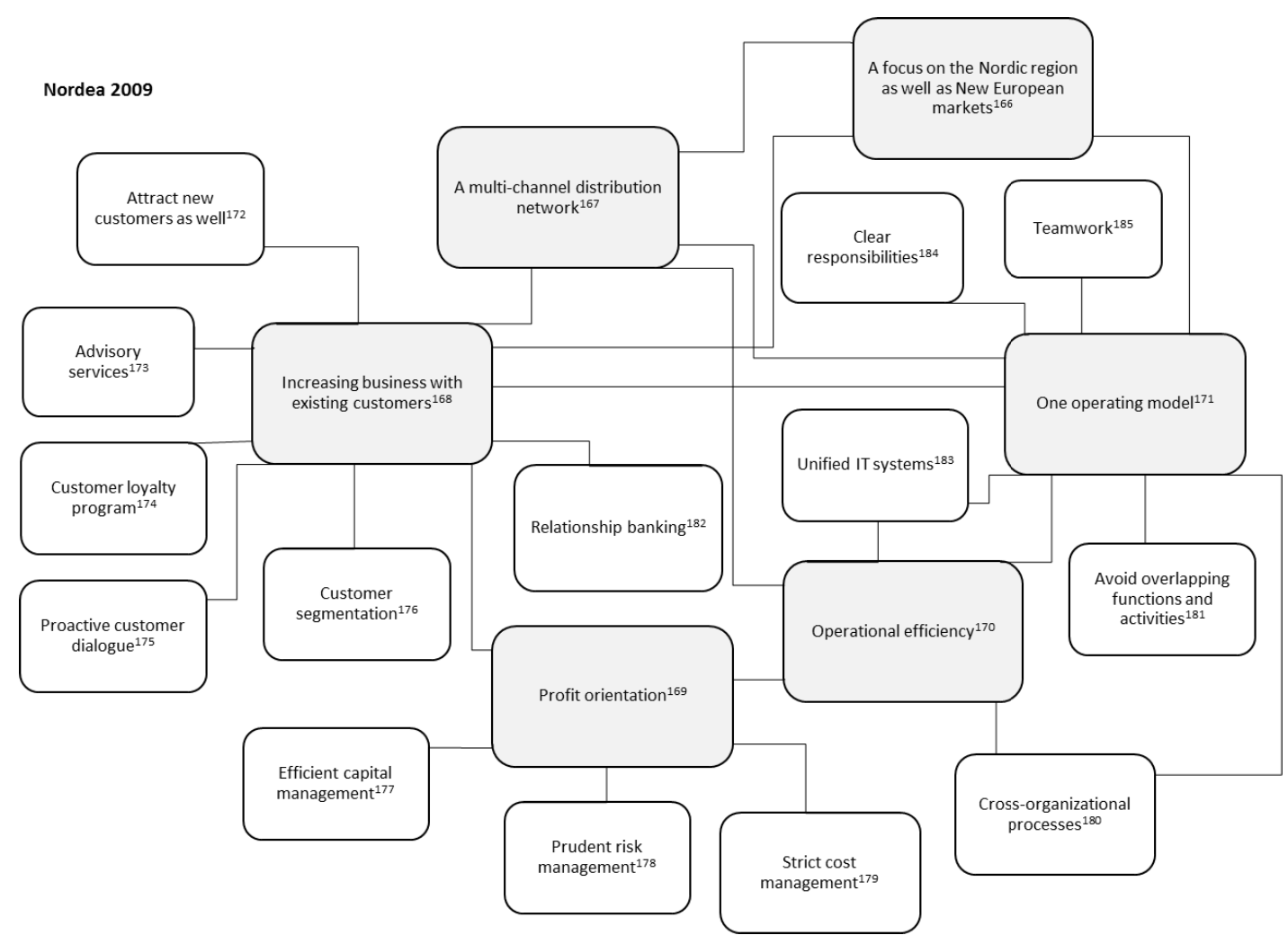

Figure 16: Nordea's Organizational System in 2009

The first core element continued to be "a focus on the Nordic region as well as new European markets." It had no elaborating elements, but it was connected to three other core elements.

The second core element for Nordea continued to be "a multi-channel distribution network." It had no elaborating elements, but it was connected with four other core elements.

"Increasing business with existing customers" continued to be the third core element in Nordea's activity system. It had six elaborating elements, which were the same to the previous year. Nordea's focus in the organic growth strategy was on growing relationships with customer segments, freeing up resources to support growth and 
finance investment for the improvement of efficiency, and alignment with post-crisis regulatory requirements (Nordea Annual Report 2009: 9).

"One operating model" continued to the fourth core element in Nordea's activity system. There were five elaborating elements for the fourth core element. All of them were the same to the previous year. Nordea's operating model was designed to support the organic growth strategy. The operating model was common for all Nordic markets, as well as being gradually implemented in the new European markets (Nordea Annual Report 2009: 12).

"Operational efficiency" continued to be the fifth core element in the activity system of Nordea. There were two elaborating elements for this core element. They were the same to the previous year.

"Profit orientation" continued to be the sixth core element in the activity system of Nordea. There were three elaborating elements for the sixth core element. Two of them were the same as one year earlier and "strict cost management" was a new elaborating element for the sixth core element.

\subsection{Nordea's organizational system in $\mathbf{2 0 1 0}$}

See Figure 17 in the next page, which shows Nordea's organizational system in 2010. I identified six core elements in Nordea's organizational system.

The first core element continued to be "a focus on the Nordic region as well as new European markets." It had no elaborating elements, but it was connected to three other core elements.

The second core element for Nordea continued to be "a multi-channel distribution network." It had no elaborating elements, but it was connected with four other core elements. 
"Increasing business with existing customers" continued to be the third core element in Nordea's activity system. It had five elaborating elements, which were the same as in the previous year.

"One operating model" continued to the fourth core element in Nordea's activity system. There were five elaborating elements for the fourth core element and they were the same as in the previous year.

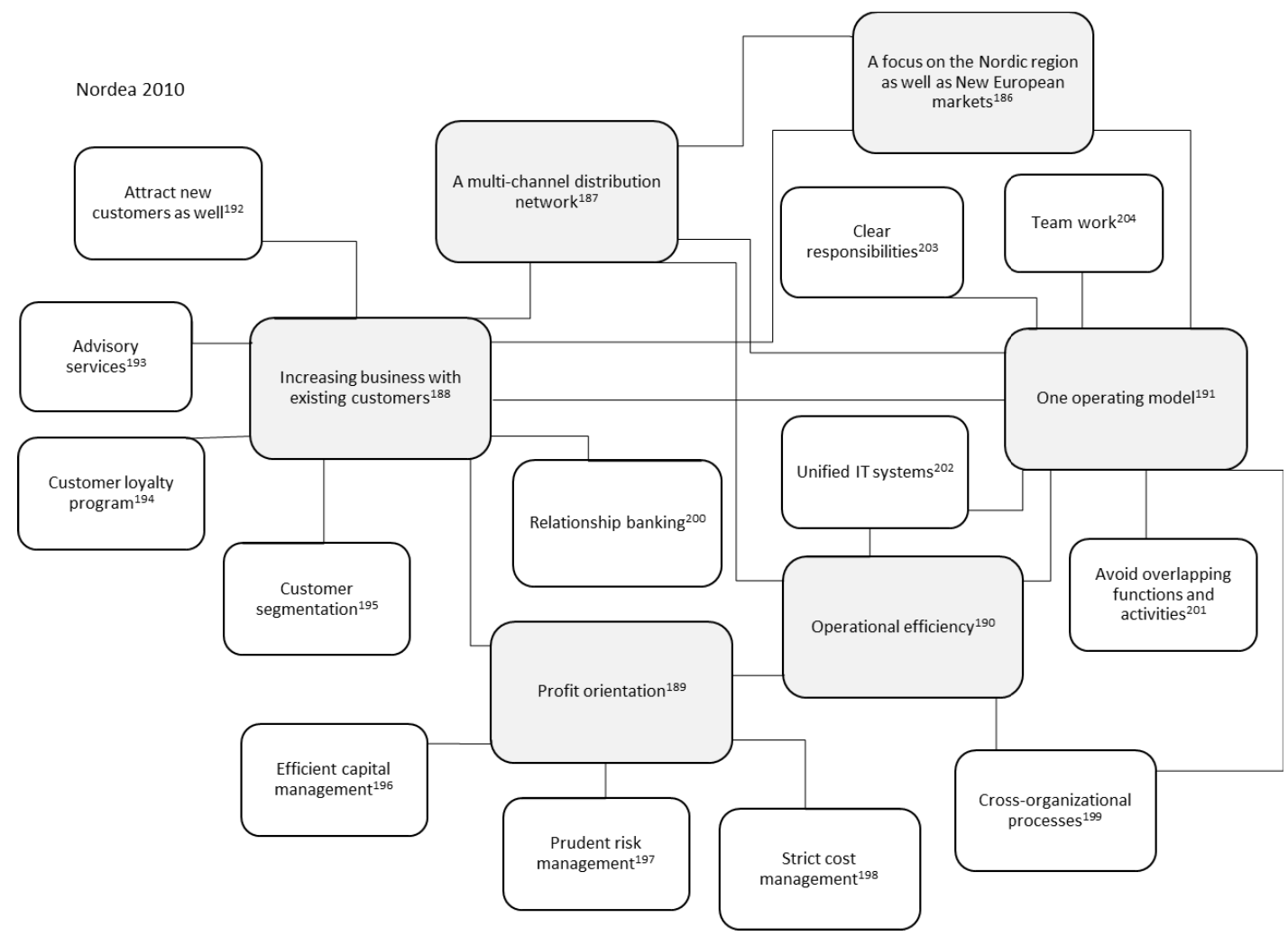

Figure 17: Nordea's Organizational System in 2010

"Operational efficiency" continued to be the fifth core element in the activity system of Nordea. There were two elaborating elements for this core element. They were the same as in the previous year. 
"Profit orientation" continued to be the sixth core element in the activity system of Nordea as in the previous year. There were three the same as elaborating elements for the sixth core element, which were the same as those from one year earlier.

\subsection{Nordea's organizational system in $\mathbf{2 0 1 1}$}

Figure 18 shows Nordea's organizational system in 2011. I identified six core elements in Nordea's organizational system.

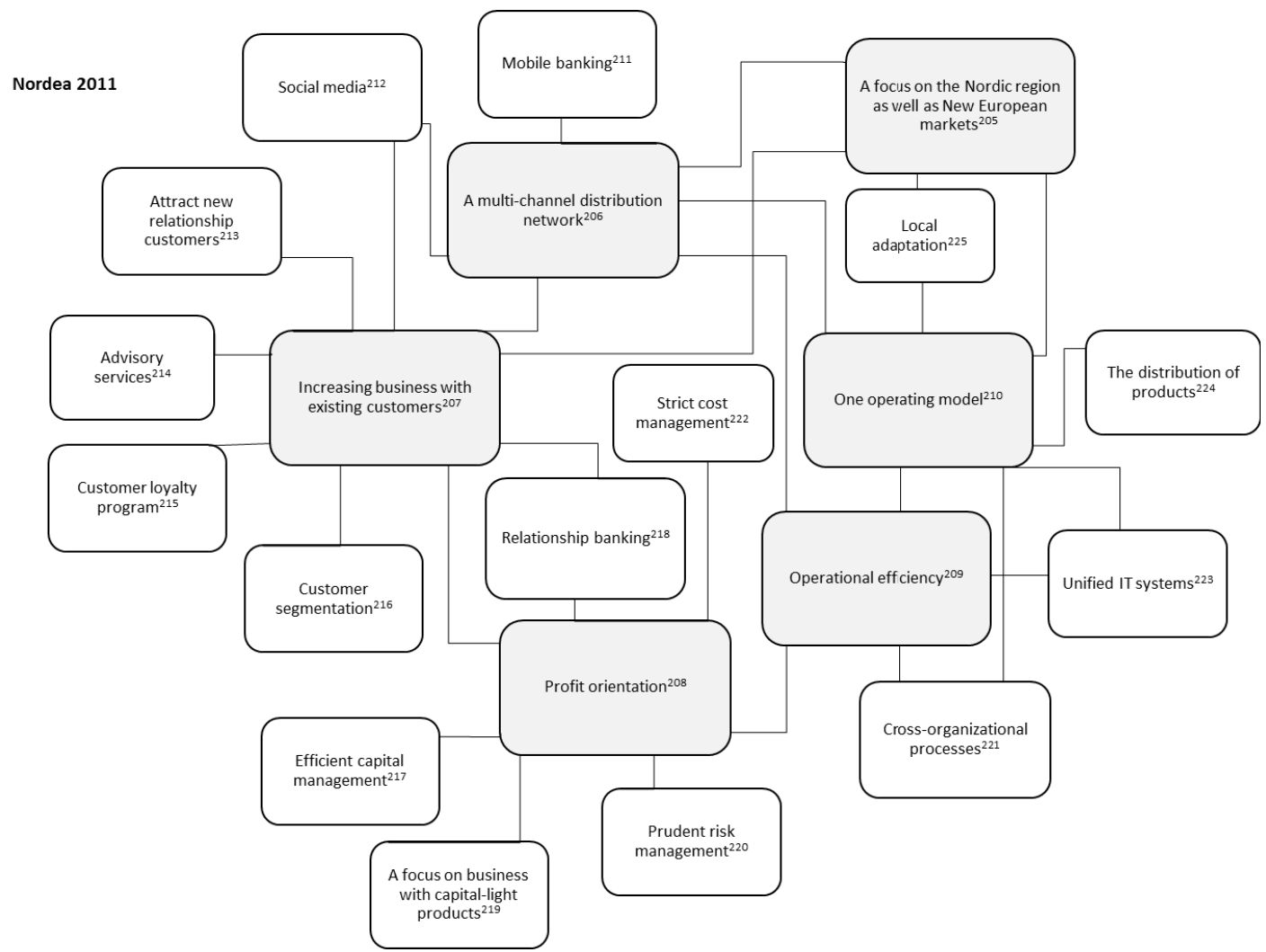

Figure 18: Nordea's Organizational System in 2011 
The first core element continued to be "a focus on the Nordic region as well as new European markets." It had no elaborating elements, but it was connected to four other core elements.

The second core element for Nordea continued to be "a multi-channel distribution network." This core element was connected with four other core elements. The second core element had two new elaborating elements: "mobile banking" and "social media." Because the penetration rate of smart phone users has increased substantially among the banks's customers the demand for mobile banking services has increased. Social media provides the bank with a new channel with which to interact actively with customers, and therefore it is an elaborating element for the second core element (Nordea Annual Report 2011: 9).

"Increasing business with existing customers" continued to be the third core element in Nordea's activity system. There were six elaborating elements for the third core element. Five of them were the same as one year earlier: "attract new relationship customers," "advisory services," "a customer loyalty program," "customer segmentation," and "relationship banking." According to Christian Clausen, since 2007 Nordea has had the relationship with customers as its main focus, because relationship customers are more satisfied, more loyal, and do more business with the bank (Nordea Annual Report 2011: 9). Therefore all of these elaborating elements support and reinforce the third core element. There was also one new elaborating element: "social media." Christian Clausen pointed out in his letter to shareholders that the bank had expanded it relationship strategy to include social media (including the bank's Facebook pages) allowing them to give instant feedback and have a direct dialogue with many of their customers (Nordea Annual Report 2011: 9).

"One operating model" continued to be the fourth core element in Nordea's activity system. There were three elaborating elements for the fourth core element. Two of them were the same as in the previous year. Two new elaborating elements were "local adaption" and "the distribution of products." Both of them support the target of having one operating model. 
"Operational efficiency" continued to be the fifth core element in the activity system of Nordea. There were two elaborating elements for this core element. The both of them were the same as in the previous year.

"Profit orientation" continued to be the sixth core element in the activity system of Nordea. There were five elaborating elements for the sixth core element. Three of them were the same as in the previous year and two of them, "a focus on business with capital light products" and "relationship banking" were new elaborating elements of the sixth core element. 


\section{FINDINGS: THE EVOLUTION OF NORDEA'S CORE ELEMENTS FROM 2000}

TO 2011

Nordea had six core elements during 2000 to 2011. What is striking is that while those core elements remained in Nordea's organizational system, the elements actually changed substantially during the time period. That is, while a core element remained in the activity system, it transformed during the study period.

Figures 19 and 20 show how each of the six core elements transformed. For example, the second row (core element 2) in the figure shows how the initial core element "a focus on e-banking" (the box marked "B") was shaped into the new shape

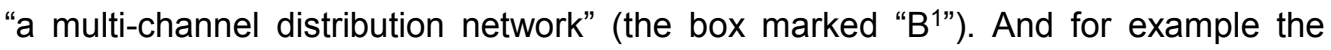
fourth row (core element 4 ) in the figure shows how the core element "an integrated banking group" (the box marked "D2") was thickened between 2002 and 2003 and was coasting from 2003 to 2004 . Table 12 detail how each of the processes matched the criteria for thickening, coasting, patching, trimming, and shaping (see also subsection 3.3.7. Phase 7: Analyzing change in Nordea's organizational systems). 


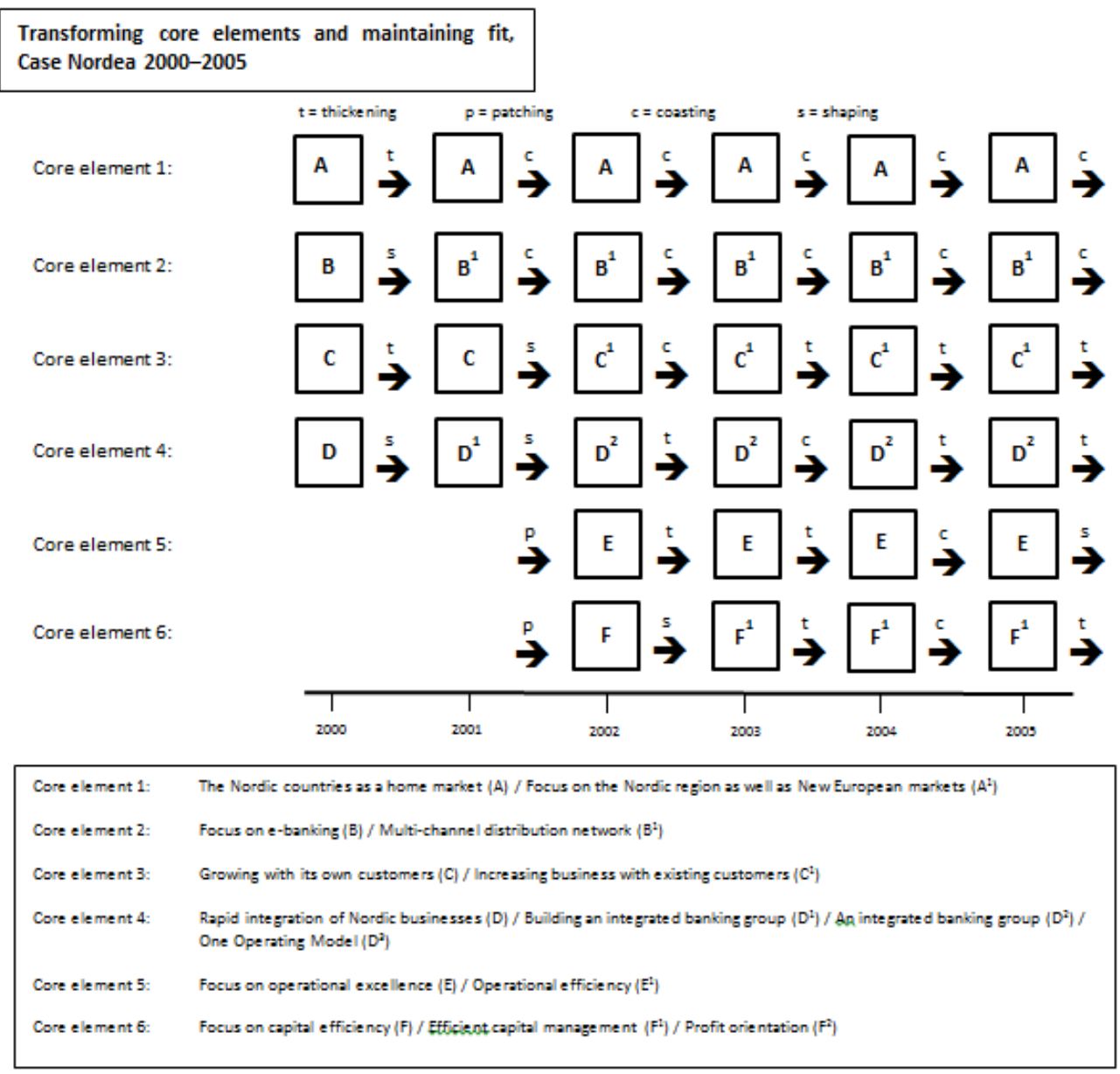

Figure 19: Transforming Core Elements and Maintaining Fit: Case Nordea 2000-2005 
Transforming core elements and maintaining fit, Case Nordea 2006-2011
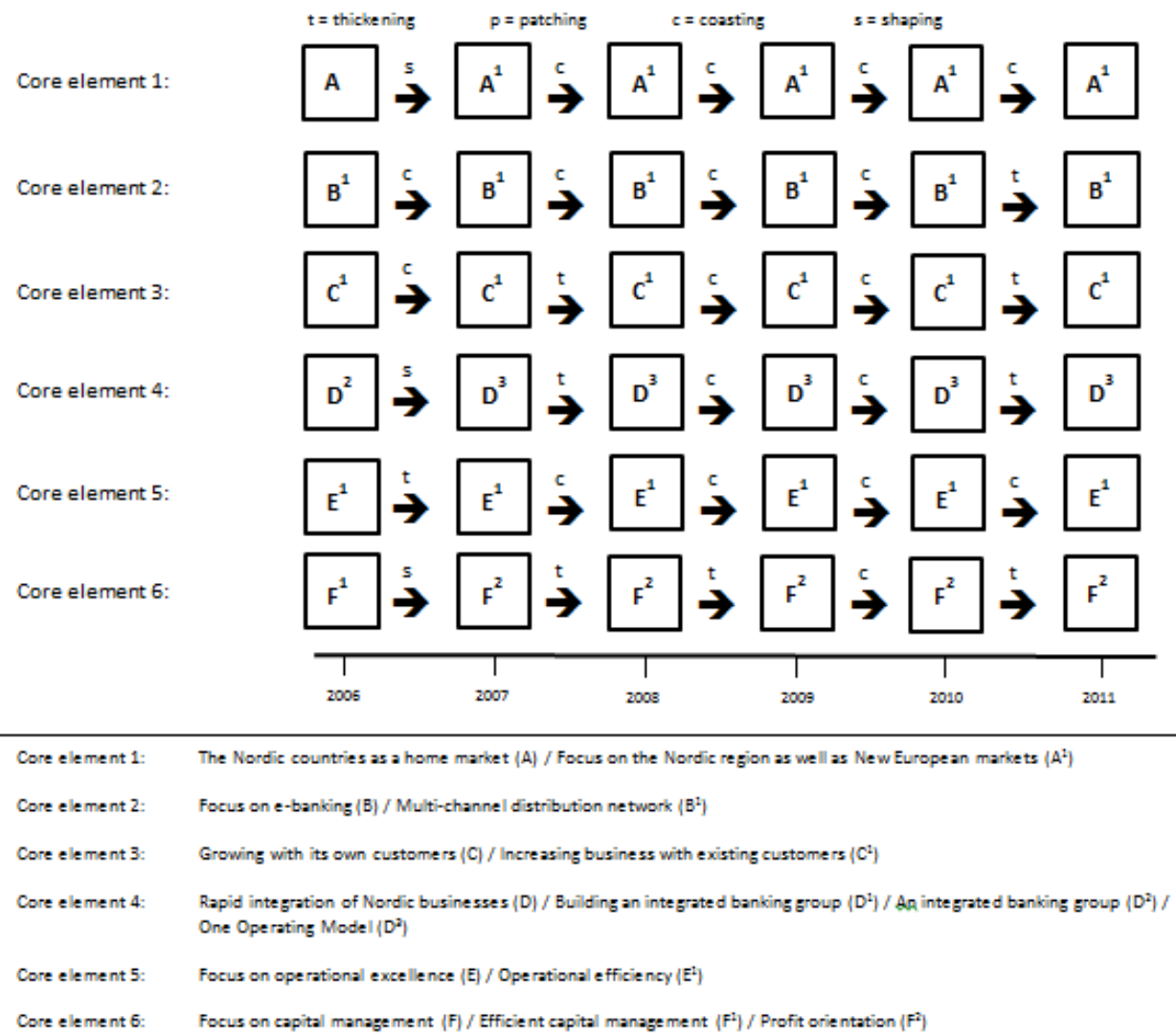

Figure 20: Transforming Core Elements and Maintaining Fit: Case Nordea 2006-2011 
Table 12: The Transformation Process of Core Elements A, B, C, D, E, and F

\begin{tabular}{|c|c|c|c|c|c|c|c|c|}
\hline $\begin{array}{l}\text { Transforming } \\
\text { Core Element }\end{array}$ & $\begin{array}{l}\text { Year } n / \\
\text { Year } n+1\end{array}$ & $\begin{array}{c}\text { Criterion } \\
1\end{array}$ & $\begin{array}{c}\text { Criterion } \\
2\end{array}$ & $\begin{array}{c}\text { Criterion } \\
3\end{array}$ & $\begin{array}{c}\text { Criterion } \\
4\end{array}$ & $\begin{array}{c}\text { Criterion } \\
\mathbf{5}\end{array}$ & $\begin{array}{c}\text { Criterion } \\
6\end{array}$ & $\begin{array}{c}\text { Transformation } \\
\text { Process }\end{array}$ \\
\hline $\mathrm{A}$ & $2000 / 2001$ & & & $x$ & & & & thickening \\
\hline $\mathrm{A}$ & $2001 / 2002$ & & & & $x$ & & & coasting \\
\hline $\mathrm{A}$ & $2002 / 2003$ & & & & $x$ & & & coasting \\
\hline A & $2003 / 2004$ & & & & $x$ & & & coasting \\
\hline A & $2004 / 2005$ & & & & $x$ & & & coasting \\
\hline $\mathrm{A}$ & $2005 / 2006$ & & & & $\mathrm{x}$ & & & coasting \\
\hline$A=A 1$ & $2006 / 2007$ & & & & & & $\mathrm{x}$ & shaping \\
\hline $\mathrm{A} 1$ & $2007 / 2008$ & & & & $x$ & & & coasting \\
\hline $\mathrm{A} 1$ & $2008 / 2009$ & & & & $\mathrm{x}$ & & & coasting \\
\hline $\mathrm{A} 1$ & $2009 / 2010$ & & & & $x$ & & & coasting \\
\hline A1 & $2010 / 2011$ & & & & $x$ & & & coasting \\
\hline$B=B 1$ & $2000 / 2001$ & & & & & & $\mathrm{x}$ & shaping \\
\hline B1 & $2001 / 2002$ & & & & $x$ & & & coasting \\
\hline B1 & $2002 / 2003$ & & & & $x$ & & & coasting \\
\hline B1 & $2003 / 2004$ & & & & $x$ & & & coasting \\
\hline B1 & $2004 / 2005$ & & & & $x$ & & & coasting \\
\hline B1 & $2005 / 2006$ & & & & $\mathrm{x}$ & & & coasting \\
\hline B1 & $2006 / 2007$ & & & & $x$ & & & coasting \\
\hline B1 & $2007 / 2008$ & & & & $x$ & & & coasting \\
\hline B1 & $2008 / 2009$ & & & & $x$ & & & coasting \\
\hline B1 & $2009 / 2010$ & & & & $x$ & & & coasting \\
\hline B1 & $2010 / 2011$ & & $\mathrm{x}$ & & & & & thickening \\
\hline $\mathrm{C}$ & $2000 / 2001$ & & & $\mathrm{x}$ & & & & thickening \\
\hline $\mathrm{C}=>\mathrm{C} 1$ & $2001 / 2002$ & & & & & & $\mathrm{x}$ & shaping \\
\hline $\mathrm{C} 1$ & $2002 / 2003$ & & & & $x$ & & & coasting \\
\hline $\mathrm{C} 1$ & $2003 / 2004$ & & & $x$ & & & & thickening \\
\hline $\mathrm{C} 1$ & $2004 / 2005$ & & $\mathrm{x}$ & & & & & thickening \\
\hline $\mathrm{C} 1$ & $2005 / 2006$ & & $\mathrm{x}$ & $\mathrm{x}$ & & & & thickening \\
\hline $\mathrm{C} 1$ & $2006 / 2007$ & & & & $x$ & & & coasting \\
\hline $\mathrm{C} 1$ & $2007 / 2008$ & & $\mathrm{x}$ & & & & & thickening \\
\hline $\mathrm{C} 1$ & $2008 / 2009$ & & & & $x$ & & & coasting \\
\hline $\mathrm{C} 1$ & $2009 / 2010$ & & & & $x$ & & & coasting \\
\hline $\mathrm{C} 1$ & $2010 / 2011$ & & $x$ & & & & & thickening \\
\hline $\mathrm{D}=>\mathrm{D} 1$ & $2000 / 2001$ & & & & & $x$ & & shaping \\
\hline $\mathrm{D} 1=>\mathrm{D} 2$ & $2001 / 2002$ & & & & & $x$ & & shaping \\
\hline D2 & $2002 / 2003$ & & & $x$ & $x$ & & & thickening \\
\hline D2 & $2003 / 2004$ & & & & & & & coasting \\
\hline D2 & $2004 / 2005$ & & & $x$ & & & & thickening \\
\hline $\mathrm{D} 2$ & $2005 / 2006$ & & $\mathrm{x}$ & $\mathrm{x}$ & & & & thickening \\
\hline $\mathrm{D} 2=>\mathrm{D} 3$ & $2006 / 2007$ & & & & & $x$ & & shaping \\
\hline D3 & $2007 / 2008$ & & $\mathrm{x}$ & $\mathrm{x}$ & & & & thickening \\
\hline D3 & $2008 / 2009$ & & & & $\mathrm{x}$ & & & coasting \\
\hline D3 & $2009 / 2010$ & & & & $x$ & & & coasting \\
\hline D3 & $2010 / 2011$ & & & $\mathrm{x}$ & & & & thickening \\
\hline$E$ & $2001 / 2002$ & $\mathrm{x}$ & & & & & & patching \\
\hline$E$ & $2002 / 2003$ & & $\mathrm{x}$ & $\mathrm{x}$ & & & & thickening \\
\hline$E$ & $2003 / 2004$ & & & $\mathrm{x}$ & & & & thickening \\
\hline$E$ & $2004 / 2005$ & & & & $x$ & & & coasting \\
\hline$E \Rightarrow E_{1}$ & $2005 / 2006$ & & & & & $x$ & & shaping \\
\hline E1 & $2006 / 2007$ & & & $\mathrm{x}$ & & & & thickening \\
\hline E1 & $2007 / 2008$ & & & & $x$ & & & coasting \\
\hline E1 & $2008 / 2009$ & & & & $x$ & & & coasting \\
\hline E1 & $2009 / 2010$ & & & & $x$ & & & coasting \\
\hline E1 & $2010 / 2011$ & & & & $x$ & & & coasting \\
\hline $\mathrm{F}$ & $2001 / 2002$ & $\mathrm{x}$ & & & & & & patching \\
\hline$F=>F 1$ & $2002 / 2003$ & & & & & $x$ & & shaping \\
\hline F1 & $2003 / 2004$ & & $\mathrm{x}$ & & & & & thickening \\
\hline $\mathrm{F} 1$ & $2004 / 2005$ & & & & $x$ & & & coasting \\
\hline $\mathrm{F} 1$ & $2005 / 2006$ & & & $\mathrm{x}$ & & & & thickening \\
\hline$F 1=>F 2$ & $2006 / 2007$ & & & & & $x$ & & shaping \\
\hline $\mathrm{F} 2$ & $2007 / 2008$ & & $\mathrm{x}$ & & & & & thickening \\
\hline$F 2$ & $2008 / 2009$ & & $x$ & & & & & thickening \\
\hline $\mathrm{F} 2$ & $2009 / 2010$ & & & & $x$ & & & coasting \\
\hline F2 & $2010 / 2011$ & & $\mathrm{x}$ & & & & & thickening \\
\hline
\end{tabular}


In the following sections I will describe the transformation process of each core element in more detail.

\subsection{Core element A: The Nordic countries as a home market (A) / A focus on the Nordic region as well as new European markets (A1)}

The first instance of shaping happened to core element A in 2007. Nordea's core element "the Nordic countries as a home market" $(A)$ turned into "a focus on the Nordic region as well as new European markets" (A1). It meant that the bank had a new strategic focus to not only focus on the Nordic countries as a home market, but to create value through organic growth in both the Nordic region as well as in new European markets. Nordea pointed out in its new strategy statement that it is targeting growth in five fast growing new European economies (Russia, Poland, Estonia, Lithuania, and Latvia) (Nordea Annual Report 2007: 12, 15). The new strategy statement meant that Nordea invested more in new European markets and exploited selected global and European business lines to generate more profitable growth (Nordea Annual Report 2007: 14). This strategy development process meant that the earlier elaborating element, "the Baltic Sea region as an emerging home market" that was core element A transformed into an essential element of the new core element, core element $\mathrm{A} 1$.

What was the background for the original core element A? Year by year Nordea emphasized in its strategy statement that the Nordic countries were Nordea's home market, the core element in the bank's organizational system. It meant that the bank provided a broad range of financial products and services to personal, corporate, and institutional customers in these countries (Nordea Annual Review 2002: 18).

According to one interview the basic idea at the beginning of Nordea's history (in 2000) was "to create a strong Nordic bank, which would have a strong market position especially in the Nordic countries" (board member, 2014). "Nordea was an example for other banks in the creation of the Nordic banking group" (top manager, 2015). Hans Dahlborg-President and CEO (2000), Vice Chairman of the Board (2001), and Chairman of the Board (2002-2010)_ "focused on the building of the Nordic banking concept" (board member, 2014). In his letter to shareholders 
Dahlborg also emphasized that Nordea was establishing a banking and insurance structure in the Nordic home market (Nordea Annual Report 2000: 7). It is important to note that the earlier Chairman of the Board, Vesa Vainio, had the "aim to create a European bank," but the new Chairman, Hans Dahlborg, wanted to concentrate on the creation of a strong Nordic bank. Therefore Dahlborg was strongly against the ABN AMRO transaction, although Vesa Vainio and the majority of the top management of the bank supported the deal (board member, 2014). Dahlborg also had "a personal interest to keep his strong power base in Sweden" and therefore he was against the deal (board member, 2014).

In its strategy statement in 2002 Nordea emphasized that the Baltic Sea region was an emerging home market for the bank. It meant that the group was the preferred partner of Nordic and international, medium-sized and large, corporate and institutional customers operating in this region (Nordea Annual Review 2002: 18). This element was an elaborating element for core element $A$.

What was the background for shaping of core element A in Nordea's activity system? Year by year Nordea was strengthening its market position in the home market and according to Lars G. Nordström-President and CEO 2002-2007-at the end of 2006 Nordea was the number one bank in the Nordic region with a strong franchise in the Baltic Sea region as well (Nordea Annual Report 2006: 2, 10). Nordea was the largest financial services group in the region with a market capitalization of approximately EUR 30 billion, total assets of EUR 349 billion, and a Tier 1 capital of EUR 13.1 billion (Nordea Annual Report 2006: 2, 5). Therefore it is possible to conclude that Nordea had already reached the original strategic growth target for the home market that had been set in 2000 . Therefore it was time to review and define its home market in a new way

How and when did Nordea review its strategy for core element A? Lars G. Nordström stepped down from his CEO's position and left the helm to Christian Clausen (President and CEO 2007-2015) in the bank's Annual General Meeting in April, 2007. Nordström pointed out in his last letter to shareholders that the organic growth strategy entails increasing business volume and therefore the bank had to take a more aggressive stance in the market and increase its efforts to capture the 
considerable potential present in all business areas (Nordea Annual Report 2006: 3). He emphasized as well that in addition to focusing on Nordic growth, the bank's organic growth strategy includes investing further in emerging markets abroad, and between 2007 and 2009 the bank planned to open up to 200 new branches in Poland and the Baltic countries. He wrote that its acquisition of a majority share in Russian Orgresbank also gave Nordea an attractive position for organic growth in the Russian market (Nordea Annual Report 2006: 4). It is important to note that Christian Clausen was also involved in the process of creating the new strategy for the bank and was committed to implementing it.

"The bank had implemented the same strategy for five years and when Christian Clausen took the helm, the organization was waiting for something new, such as the new speed of expansion" (top manager, 2014). Through the new CEO the organization reached a new level of aspiration, even though Christian Clausen did not make any big changes to the business strategy of Nordea. In 2007, in Clausen's first letter to shareholders, he emphasized that Nordea had a clear growth strategy focused on increasing business with current customers and attracting new customers in the Nordic region, Russia, Poland, and the Baltic countries. He pointed out that Nordea had ambitious strategic targets, not least expressed through the bank's goal of doubling the risk-adjusted profit from 2006 to 2013, implying an average annual growth of around 10 per cent (Nordea Annual Report 2007: 4). Therefore Nordea had to review expanding its home market.

The implication of this development process in Nordea's strategy was that its core element A ("the Nordic countries as a home market") turned into "a focus on the Nordic region as well as new European markets" (A1). This development process was shaped because the core element $A$ was transformed into a new shape (A1) during one year, and in fact during the strategy process of the new CEO. It seems that strategic executives led by the new CEO generated qualitative changes in the core element. It was not patching because it was not a question about the "creation of a new core element and its reinforcement by new elaborating elements" and it was not trimming because it was not a question of the "deletion of a core element and its elaborating elements" (Siggelkow, 2002: 125). The new core element (A1) includes 
the content of the earlier core element $(A)$, but it is wider in scope. In this shaping process the top management of Nordea transformed the strategic core element $A$ into a new shape in order to emphasize the bank's strategic focus area in a new way. This new geographic focus area of Nordea was broader, and therefore the bank had a better possibility of reaching its long-term growth target of an annual average growth of around 10 per cent. The bank was targeting to be the leading Nordic bank without exact geographical limits (Nordea Annual Report 2007: 12). In this process it was more a question about the shaping of the core element as it was about making big changes all at one time. During this developmental process, Nordea's top management really generated qualitative changes to the core element, and this also supports my conclusion that it was a question of a shaping process.

Another implication of the evolution process of Nordea's strategy was that an elaborating element for the core element $A$ transformed into an essential element of the new core element (A1). The new core element (A1) did not have any elaborating element, but it retained interdependence with the three previous core elements: "a multi-channel distribution network" (B1), "increasing business with existing customers" (C1), and "one operating model" (D3).

\subsection{Core element B: A focus on e-banking (B) / A multi-channel distribution network (B1)}

The first instance of shaping to core element B happened in 2001. Nordea's core element B ("a focus on e-banking") turned into the core element B1 ("a focus on a multi-channel distribution network"). Earlier "a multi-channel distribution network" was an elaborating element for core element $B$.

What is the background for core element B? Around the time of the internet bubble, in 2000 , it was very typical in the banking industry to put a lot of focus on developing internet banking. Many new online banks (promising to reinvent banking) were launched, such as Wingspan in the US and Egg in Great Britain. Most of them were soon closed or sold because of poor technological solutions and the conservatism of customers (The Economist, 2013). At the same time Nordea pointed out in its Annual Report 2000 that the internet continued to change the world of financial services and 
the bank wanted to be at the forefront of these developments and intended to maintain leadership in developing wired and wireless services for its customers via the internet. In order to further strengthen the bank's market leadership, Nordea made its electronic service concept "Solo" available throughout its home market (Nordea Annual Report 2000: 24). "It was a part of the existing boom to concentrate on e-banking [...] Merita having been good in e-banking was a reason for this emphasis" (board member, 2014). "Merita had been strong expert and forerunner globally in e-banking before the creation of Nordea". (top manager, 2015)

In early 2000 Nordea, like other large banks, highlighted the role of e-banking in its strategy. For example, Hans Dahlborg—President and CEO (2000), Vice Chairman of the Board (2001), and Chairman of the Board (2002-2010)—emphasized the bank's investments in its leading position in e-banking. He pointed out as well that in 2000 Nordea was granted a global award for "Best Online Business Strategy" by the financial services industry magazine The Banker (Nordea Annual Report 2000: 7-8). Dahlborg wrote in his letter to shareholders that the investments in Nordea's world leading position in e-banking had also helped to increase customer satisfaction. $\mathrm{He}$ wrote that Nordea already had more than two million e-customers (Nordea Annual Report 2000: 7-8). In its strategy statement Nordea highlighted that it is focusing on long-term growth areas like e-banking (Nordea Annual Report 2000: 10). The interviewees also reinforced the bank's strong focus on e-banking in early 2000 (board member, 2014; top manager, 2014).

According to one academic study, internet banking is characterized by large initial investments and substantial reputation advantages. These factors generate scale economies and low marginal costs. Internet banking facilitates co-ordination between the branches of a bank, and a large bank can offer innovative services to reduce its average costs much more than a small bank can, as a large bank deals with a higher number of customers and banking transactions (Corrocher, 2006). A multi-channel distribution network includes both e-banking and branches with other potential service channels.

When did Nordea start the shaping process of core element B? In 2001 the bank no longer emphasized the role of e-banking separately in its strategy communication. 
For example, Thorleif Krarup wrote in his letter to shareholders that the bank was responding to the demand for innovative e-services that empower customers and release resources for improved personal relationships and advice (Nordea Annual Report 2001: 11). He pointed out as well that in multi-channel distribution and eservices, the bank wanted to retain a world leadership position (Nordea Annual Report 2001: 12).

How did I observe this shaping process of core element B? In its strategy statement Nordea highlighted that the bank has a strong distribution strategy, with customers choosing the most appropriate mix of distribution channels. Nordea aimed to strike the optimal balance between personal and electronic services in its multi-channel distribution network. As part of this strategy the bank wanted to also provide topranking e-banking services for its customers (Nordea Annual Report 2001: 23).

The above statements by the top management of the bank reinforce that Nordea's core element B was turning into core element B1. "Most of us in the top management of the bank did not believe that successful e-banking would be possible without a physical branch network" (top manager, 2014). Therefore core element B was turned into the new shape of B1 ("a multi-channel distribution network"). "E-banking developed step by step into a multichannel model" (top manager, 2015).

This development process was shaping because core element B was transformed into the new shape of B1, and the identity of the core element ("a focus on ebanking") was maintained as an essential part of the new core element ("a multichannel distribution network") and it changed the core element in a substantial way. In this shaping process the top management of Nordea transformed the strategic core element into a new shape in order to emphasize the bank's strategic focus area (its distribution channel network) in a new way. During the development process the strategic executives of Nordea generated qualitative changes in the core element. This development process was not patching because it was not a question about the "creation of a new core element and its reinforcement by new elaborating elements" and it was not trimming because it was not a question of the "deletion of a core element and its elaborating elements" (Siggelkow, 2002: 125). 
What were the implications of this shaping process? Earlier an elaborating element for core element B ("a multi-channel distribution network") replaced core element B and the new core element (B1) had two elaborating elements: "top-ranking e-banking services" and "easy to access." The new core element (B1) continued its interdependence with the two previous core elements: core element $A$ and core element $\mathrm{C}$.

\subsection{Core element C: Growing with its existing customers (C) / Increasing business with existing customers (C1)}

The first instance of the shaping of core element C happened in 2002. Nordea's core element C ("growing with its own customers") transformed into core element C1 ("increasing business with existing customers"). It meant that the bank had more focus on sales efforts and advisory capabilities, in order to increase the share of wallet of existing customers.

What was the background for core element C? Nordea pointed out in its strategy statement in 2000 that the bank has a clear growth strategy and its first priority is to grow with its existing customers (Nordea Annual Report 2000: 10). "Growing with its existing customers was an important part of the strategy at the beginning" (board member, 2014). "The new bank focused on growing with its existing customers, especially with retail customers" (top manager, 2015). Thorleif Krarup-President and CEO 2001-2002-confirmed the same principle in his letter to shareholders that Nordea's first priority was to grow with its existing customers and therefore the bank focused on harmonizing customer concepts and Nordic investments in the Solo concept (an e-banking concept) (Nordea Annual Report 2000: 10). These statements reinforce my conclusion that "growing with its existing customers" was a core element in Nordea's activity system.

When did Nordea start the shaping process of core element C? Lars G. NordströmPresident and CEO 2002-2006-sharpened Nordea's strategy in 2002 when he started as the President and CEO of Nordea. Why did Nordea need to transform core element C? In 2002 the income from Nordea's core business activities were stable and therefore the bank needed to emphasize a focus on sales efforts and advisory 
capabilities, in order to increase the share of wallet of existing customers (Nordea Annual Review 2002: 19). "Nordea had 10 million customers, but the bank was the main bank for only 30 per cent of those customers" (top manager, 2014). Therefore Nordea decided to put more focus on increasing the share of wallet of the existing customers.

Later Nordström emphasized this new core element (C1) many times, for example in his letter to shareholders in the Annual Report 2005 he wrote that the bank's strategy - to increase business with existing customers and to manage costs and risks strictly—had been proven to be right (Nordea Annual Report 2005: 5). One year later in his letter to shareholders he emphasized that the organic growth strategy entails increasing business volume with its existing customers and attracting new customers, and that they have to take a more aggressive stance in the market in order to capture the considerable potential present in all business areas. He pointed out that, for example, in retail banking only 30 per cent of the bank's active customers were so-called Gold customers, and therefore they had a lot of room to raise this number significantly by increasing its share of wallet from customers (Nordea Annual Report 2006: 6).

The focus on this core element (C1) has continued in Christian Clausen's (President and CEO 2007-2015) time. One of pillars in Nordea's strategy for profitable organic growth was to increase business with existing Nordic customers and attract new customers in the upper segments (Nordea Annual Report 2007: 14). Clausen has emphasized many times the key role of relationship banking in his comments since 2007. The bank's main target was to create great customer experiences (Nordea Annual Report 2007: 9).

This development process was a shaping one because core element C ("growing with its own customers") transformed into a new shape (C1: "increasing business with existing customers") over one year and the core element's identity (growth and customer focus) was maintained almost the same, but during this development process Nordea's top management generated qualitative changes to the previous core element $(\mathrm{C})$ by putting more focus on increasing Nordea's share of the customer's wallet. The new core element $(\mathrm{C} 1)$ includes the content of the earlier core 
element, but it is broader than the earlier core element $\mathrm{C}$. This development process was not patching because it was not a question about the "creation of a new core element and its reinforcement by new elaborating elements" and it was not trimming because it was not a question of the "deletion of a core element and its elaborating elements" (Siggelkow, 2002: 125).

What were the implications of the shaping process, when core element $C$ turned into the new core element $(\mathrm{C} 1)$ ? Core element $\mathrm{C}$ had two elaborating elements: "the cross-selling of banking and insurance services" and "a deepening partnership with customers." Nordea divested the general insurance business in 2002 and therefore the elaborating element of "the cross-selling of banking and insurance services" was no longer valid (Nordea Annual Review 2002: 9). The new core element (C1) had one elaborating element: "acquiring new profitable customers." The new core element (C1) was interdependent with three other core elements: core element B1, core element $\mathrm{E}$, and core element $\mathrm{F} 1$.

\subsection{Core element D: The rapid integration of Nordic businesses (D) I Building an integrated banking group (D1) / An integrated banking group (D2) / One operating model (D3)}

The first instance of the shaping of core element D happened in 2001. Nordea's core element D ("the rapid integration of Nordic businesses") turned into D1 ("building an integrated banking group").

What was the background for the core element D? After the merger between MeritaNordbanken and Unidanmark in 2000, the rapid integration of Nordic businesses was the name of the game. After the first nine months of merger integration a new business organization with six business areas, supported by a corporate center and group staff, had been established (Nordea Annual Report 2000: 26-27). Core element $D$ had four elaborating elements: "the exchange of best products," "adoption of best practice," "harmonizing customer concepts," and "products and distribution channels are coordinated and integrated." All of them described well the kind of actions that are key in a rapid integration process. 
When did Nordea start the shaping process of core element D? In 2001 Thorleif Krarup (President and CEO 2001-2002), emphasized that Nordea was building an integrated Nordic financial group providing universal banking and insurance services. It meant legal structure changes, all core businesses were branded Nordea, and that a group-wide culture change program-“From Words to Action"-based around the joint Nordea values was implemented (Nordea Annual Report 2001: 11). It was time to take the next step and the top management of Nordea moved its focus from rapid integration to the process of building an integrated banking group. It meant that core element D turned into the new core element, core element D1 ("building an integrated banking group (Nordea Annual Report 2001: 11). This new core element (D1) had four elaborating elements: "all core businesses are branded Nordea," "a group-wide planning and performance model," "the use of benchmarking and best practices," and "for every business area, there is one and only one best way."

This development process was a shaping process because core element $D$ transformed into a new shape (D1) over one year. The core element's identity was maintained almost the same, but during this development process the top management of Nordea generated qualitative changes to the previous core element (D) by putting more focus on building an integrated banking group instead of only focusing on rapid integration after several mergers. The new core element (D1) includes the content of the earlier core element (D), but it was broader than core element $\mathrm{D}$. In this shaping process the top management of Nordea transformed the strategic core element into a new shape in order to emphasize the bank's strategic focus in a new way. This development process was not patching because it was not a question about the "creation of a new core element and its reinforcement by new elaborating elements" and it was not trimming because it was not a question of the "deletion of a core element and its elaborating elements" (Siggelkow, 2002: 125).

Although Thorleif Krarup launched a program to build an integrated bank, he was not successful in leading the process and therefore he had to step down from his CEO position in 2002. "The nomination of Krarup as the CEO was the wrong decision" and "during his CEO time nothing happened in integration" (board member, 2014). His successor was Lars G. Nordström, President and CEO from 2002 to 2007. During Nordström's time integration really started to go forward (board member, 2014; top 
manager, 2014). "Nordström started to purposefully integrate different functions" (board member, 2014), and this was the start for the second shaping process of core element D.

The second instance of shaping core element D happened in 2002. Nordea's core element D1 ("building an integrated banking group") transferred into a new shape (D2: "An integrated banking group"), which really meant speeding up integration and unification. It also meant more focus on core business, and therefore Nordea divested the general insurance business and non-core businesses such as Contant and Europay Norge AS. This was the agenda of the bank's new CEO, Lars G. Nordström (Nordea Annual Review 2002: 9).

This development process was a shaping process because core element D1 transformed into a new shape (D2) over one year and the core element's identity ("an integrated banking group") was maintained almost the same, but during this development process Nordea's top management generated qualitative changes (speeding up integration and unification) and introduced them into the previous core element (D1). The new core element (D2) includes the content of the earlier core element (D1), but it is broader and more focused than the earlier core element (D1). In this shaping process the top management of Nordea transformed the strategic core element into a new shape to emphasize the bank's strategic focus in a new way. This development process was not patching because it was not a question about the "creation of a new core element and its reinforcement by new elaborating elements" and it was not trimming because it was not a question of the "deletion of a core element and its elaborating elements" (Siggelkow, 2002: 125).

The new core element (D2) had three elaborating elements: "speed-up integration," "benchmarking within the group," and "the transfer of best practices within the group." To implement the new priorities of the bank, Lars G. Nordström launched three internal keywords to highlight the need for improvements and changes in the organization: focus, speed, and performance (Nordea Annual Review 2002: 10).

In 2007 Christian Clausen, President and CEO from 2007 to present, started in his new position and he launched a new operating model and adjusted the organization. 
According to him the new organization integrates and optimizes cross-organizational processes and ensures that all parts in the value chain work towards creating value for the bank's customers (Nordea Annual Report 2007: 5). My conclusion is that it was a new form of core element D2.

The third instance of shaping core element D happened in 2007 . The previous core element (D2), took on a new form as "one operating model" (D3). This new core element (D3) has been highlighted by the top management of Nordea many times since 2007 (for example Nordea Annual Report 2010: 10). "During Christian Clausen's period as CEO the focus was really on the creation of one operating model" (board member, 2014). This new core element (D3) had seven elaborating elements: "cross-organizational transparency," "strong customer orientation," "clear responsibilities," "team work," "cross-organizational processes," "unified IT systems," and "resource optimization." The new core element (D3) was linked to three other core elements: A2, B2, and E1.

This development process was a shaping process because the core element (D2) transformed into a new shape (D3) over one year and the core element's identity ("an integrated banking group") was maintained almost the same, but during this development process Nordea's top management, led by the new CEO, generated qualitative changes (to integrate and optimize cross-organizational processes) to the previous core element (D2). The new core element (D3) includes the content of the earlier core element ("an integrated banking group"), but it is broader and more focused than the earlier core element (D2). In this shaping process the top management of Nordea transformed the strategic core element into a new shape to emphasize the bank's strategic focus in a new way. This development process was not patching because it was not a question about the "creation of a new core element and its reinforcement by new elaborating elements" and it was not trimming because it was not a question of the "deletion of a core element and its elaborating elements" (Siggelkow, 2002: 125). 


\subsection{Core element E: A focus on operational excellence (E) / Operational efficiency (E1)}

The first instance of shaping happened to core element $E$ in year 2006. Core element E ("a focus on operational excellence") transformed into core element E1 (“Operational efficiency").

What was the background for core element E? Nordea highlighted in strategy statements in 2003 that operational excellence was a top priority throughout the bank (Nordea Annual Review 2003: 17). "Operational excellence was a key focus area in Nordström's time" (top manager, 2015). From year 2003 to year 2005 operational excellence was one of the key elements in the bank's strategy statements. "Best practices were a key element in the business strategy" (top manager, 2015). Elaborating elements for core element E in 2005 were "strict cost management," "reduce complexity," and "product development and time-to-market have a high priority." In 2004 there were an additional three elaborating elements for core element E: "unification," "standardization," and "centralization."

When did Nordea start the shaping process of core element E? In 2006 Nordea talked about operational excellence in the strategy communication. "Nordea had three large strategy processes between 2000and2011: the first was in 2000, the second one in 2002 (McKinsey was a consultant in this process), and the third one was during 2006 and 2007)" (top manager, 2015). After this third strategy, the process of improving operational efficiency, there was a new focus area and then a new core element (E1) in the bank's activity system. The background for the change was that Nordea's cost-to-income ratio had come down by more than 10 percent since 2002, among other reasons through increased productivity in the central processing areas and general strict cost management. It was time to take the next step. Key areas for further operational efficiency included a number of lean banking and structural cost initiatives and the releasing of sales capacity in the branches (Nordea Annual Report 2006: 11).

Lars G. Norström, President and CEO (2002-2007), pointed out in his letter to shareholders that, having successfully transformed four banks into one unified 
operating model, the bank now had unique competence in consolidations and an invaluable knowledge about how to create efficiency (Nordea Annual Report 2006: 3). This comment also supports my view that the bank was moving toward a focus on operational efficiency.

This development process was a shaping process because core element $E$ ("a focus on operational excellence") transformed into a new shape (E1: "operational efficiency") over one year and the core element's identity ("operational capability") was maintained almost the same, but during this development process Nordea's top management generated qualitative changes (speeding up integration and unification) and this was incorporated into the previous core element $(E)$. The new core element (E1) includes the content of the earlier core element (E), but it is broader and more focused than the earlier core element $(E)$. In this shaping process the top management of Nordea transformed the strategic core element into a new shape in order to emphasize the bank's strategic focus in a new way. This development process was not patching because it was not a question about the "creation of a new core element and its reinforcement by new elaborating elements" and it was not trimming because it was not a question of the "deletion of a core element and its elaborating elements" (Siggelkow, 2002: 125).

The new core element (E1) had five elaborating elements: "resource optimization," "cross-organizational processes," "harmonizing products, processes, and IT platforms," "reduce complexity," and "strict cost management."

\subsection{Core element F: Profitability prioritized over growth (F) / Efficient capital management (F1) / Profit orientation (F2)}

What was the background for core element F? Lars G. Nordström, President and CEO (2002-2007), put some priorities in place to improve performance when he started in his CEO role in 2002. Nordea pointed out in its strategy statement that it was optimizing the use of capital and profitability was prioritized over growth, which was reflected in the way Nordea allocated capital (Nordea Annual Review 2002: 20). 
The first instance of shaping happened to core element $F$ in 2003. Core element $F$ ("Profitability prioritized over growth") turned into the new core element (F1: "Efficient capital management"). One example of this development process was that Nordström pointed out in his letter to shareholders that one of the short-term top priorities for the bank was to ensure capital efficiency, and the bank made some actions to strengthen its capital efficiency through divestments of real estate and other non-core assets. The bank also implemented an economic capital and economic profit framework (Nordea Annual Review 2003: 3).

This development process was a shaping process because core element $F$ ("profitability prioritized over growth") transformed into a new shape (F1: "efficient capital management") over one year and the core element's identity (profitability) was maintained the same, but during this development process Nordea's top management generated qualitative changes ("a focus on capital efficiency") into the previous core element $(F)$. The new core element $(F 1)$ includes the content of the earlier core element (a focus on profitability), but it is broader than the earlier core element $(F)$. In this shaping process the top management of Nordea transformed the strategic core element into a new shape to emphasize the bank's strategic focus in a new way. Another implication of the evolution process of Nordea's strategy was that an elaborating element ("the efficient use of capital") for core element $F$ transformed into an essential element of the new core element (F1). This development process was not patching because it was not a question about the "creation of a new core element and its reinforcement by new elaborating elements" and it was not trimming because it was not a question of the "deletion of a core element and its elaborating elements" (Siggelkow, 2002: 125).

What kind of implications resulted from this shaping process? The elaborating elements for core element F were: "the efficient use of capital," "a focus on credit quality," "an economic profit-driven management system," and "acquiring new profitable customers." The new core element (F1) also had four elaborating elements, but only "a focus on credit quality" was the same as earlier. Other elaborating elements were "an economic profit-driven management system," "divestment of non-core assets," and "the outsourcing of non-core activities." 
The second instance of shaping happened to the core element (F1) in 2007. The core element (F1) turned into a new core element (F2: "Profit orientation").

How did I observe this second shaping process of core element F? When the new President and CEO of Nordea, Christian Clausen (2007- ), wrote his first letter to shareholders, he pointed out that it was time to take the next step forward in Nordea's development process and form a great Nordea. He emphasized that one core element for a great company is a strong profit orientation (Nordea Annual Report 2007: 4). Nordea also pointed out in its strategy statement in 2007 that a strong profit orientation was the foundation for generating results and making room for investments in future growth (Nordea Annual Report 2007: 12).

The pressure to put more focus on profit orientation was also increased by a new major shareholder of Nordea. During the year 2007 Nordea got a new active institutional major owner, the Finnish insurance group Sampo. Sampo owned almost ten per cent of Nordea's shares at the end of 2007 and Sampo increased its ownership to a level of 12 per cent during 2008. Sampo Group's CEO Björn Wahlroos was nominated to be a board member on the Board of Directors of Nordea in the Annual General Meeting 2008. According to one interviewee, his nomination as a board member meant that there was much more focus on shareholder value creation on the agenda of Nordea's board. "Shareholder value creation came really into the agenda when Nalle [Björn Wahlroos] stepped onto the board, and quite soon he got supporters on the board" (board member, 2014). There were "different inorganic growth plans on the board's agenda, but Nalle was very pragmatically against them" (board member, 2014).

This development process was a shaping process because the core element (F1: "efficient capital management") transformed into a new shape (F2: "profit orientation") over one year and the core element's identity (profitability) was maintained the same, but during this development process Nordea's top management generated qualitative changes (a focus on shareholder value creation) that were incorporated into the previous core element (F1). The new core element (F2) includes the content of the earlier core element (F1), but it is broader than core element $F 1$. In this shaping process the top management of Nordea transformed the strategic core 
element into a new shape to emphasize the bank's strategic focus in a new way. This development process was not patching because it was not a question about the "creation of a new core element and its reinforcement by new elaborating elements," and it was not trimming because it was not a question of the "deletion of a core element and its elaborating elements" (Siggelkow, 2002: 125). 


\section{DISCUSSION}

My detailed analysis of Nordea's evolution shows that shaping elements is an essential way through which companies maintain fit between their core elements and yet transform and grow radically. My study makes two key theoretical contributions as well as contributions to the understanding of the banking industry. All these are elaborated below.

\subsection{Shaping as a fifth process to describe the creation and elaboration of core elements}

My findings contribute to the research on the processes that allow companies to evolve toward fit. Siggelkow (2002) recognized four processes that a company uses: thickening (the reinforcement of an existing core element by new elaborating elements), patching (the creation of a new core element by new elaborating elements), coasting (no further elaboration of a new core element in a given period), and trimming (the deletion of a core element and its elaborating elements). I identified a fifth one: shaping, which refers to the process of transforming a core element while maintaining its identity and relationships with other elements.

The recognition of the shaping process recognizes the importance of continuous learning in strategy development. It does not seem sufficient for strategic leaders to determine their core elements once and then periodically review if those core elements continue to be relevant. Rather, it seems that strategic leaders should also generate qualitative changes to the core elements. In other words, it is not sufficient to consider whether a core element is present or not in a digital (on-off) fashion, and a richer understanding of the element and how it operates may be necessary for effective strategy development over time.

Sometimes important strategic elements may have very concrete roots. In Nordea's case, in particular, its core element "a multi-channel distribution network," which is very abstract, had its roots in developing a good online service for the firm. That is, an all-encompassing strategic element was developed from a simple concrete thing. Similar stories are not uncommon in the entrepreneurial context, when big 
organizations grow up from relatively simple things that are then shaped further and further. For example, Google started from a research paper, which was shaped into a local search engine, and then shaped (and elaborated) a bit more. Likewise, Facebook started as a local game for rating pictures that was shaped into an ever more complex product.

One of the interviewees used the word "shaping" when he described the development process regarding how Nordea's strategic focus on e-banking transformed into a new shape "a multi-channel distribution network," because ebanking was already established and it had a growing amount of customers, but the branch network was still the dominant distribution channel for the bank (top manager, 2015). There were also top managers in the top management of Nordea who did not believe that e-banking could result in a single distribution channel for the bank in the future, and therefore the consensus view among the top management transformed into a new shape, resulting in one of the core elements in the bank's strategy becoming a focus on a multi-channel distribution network with top-ranking e-banking services (top manager, 2014). It was a shaping process when top management transformed its strategic core element into a new shape to emphasize its strategic focus in a new way. My conclusion is that this example shows how strategic leaders can create qualitative changes in the core elements of a company's business strategy, and this perception emphasizes the importance of continuous learning in strategy development. In the previous academic literature this kind of development process of a core element in an organization's activity system was not found.

Siggelkow emphasized in his study that "the concepts of thickening, patching, coasting, and trimming allow us to describe the developmental path of an organization consistently ... Within each of these periods the organization can engage in three processes with respect to each existing core element (thickening, coasting, or trimming) and one process with respect to new core elements (patching)" (Siggelkow, 2002: 150-151). My perception is that Siggelkow's concepts are not broadand diverse enough to describe the possible developmental paths of an organization because strategic leaders can create qualitative changes in the core elements of a company's business strategy, and this process is not the same as any of the four concepts defined by Siggelkow. 
Another good example of the process of transforming an existing core element into a new shape over the course of time happened when Nordea's core element "the Nordic countries as a home market" transformed into a new shape "a focus on the Nordic region as well as new European markets." Thus the bank had a new strategic focus to not only focus on the Nordic countries as a home market, but also to create value through organic growth in both the Nordic region and in new European markets. Originally the basic idea at the beginning of Nordea's history (in 2000) was to create a strong Nordic bank, which would have a strong market position in the Nordic countries in particular (e.g., Nordea Annual Report 2000: 7; Dahlborg, 2014: 298; board member, 2014). Nordea had strengthened its market position in the home market and at the end of 2006 the bank was the number one bank in the Nordic region with a strong franchise as well in the fast growing Baltic Sea region. Thus Nordea had reached the original strategic target in its home market that was set in 2000.

Therefore the top management of Nordea had time to review and define the bank's home market in a new way. At the same time, Lars G. Nordström stepped down from his CEO position and left the helm to Christian Clausen in Nordea's Annual General Meeting in April, 2007. Nordström pointed out in his last letter to shareholders that the bank's organic growth strategy entails increasing business volume, and therefore Nordea has to take a more aggressive stance in the market and, in addition to focusing on Nordic growth, the bank's organic growth strategy should include investing further abroad, in emerging markets in the Baltic Sea region including Russia. The new CEO of the bank, Christian Clausen, was also involved in the process of building this new strategy for the bank and he was committed to implementing it. This example shows how the top management of Nordea transformed and expanded its strategic core element into a new shape to emphasize its strategic growth and geographical focus areas in a new way. Shaping is, for example, the process when the strategic leaders of an organization transform or expand the organization's core element into a new shape to emphasize the organization's strategic focus areas in a new way. My perception is that the four processes defined by Siggelkow do not take into account this kind of approach to developing an organization's business strategy and its core elements. 
In contrast to what previous theory would suggest, my findings show that the company's core elements can undergo major changes while their relationships continue to have a fit-like character. My conclusion is that to understand strategy as a constellation of organizational elements it is not adequate to focus on the relationships between the elements, one must also to be mindful of the qualitative nature and changes in the elements themselves. Many of these changes can be better characterized as "emergent" rather than "designed." There was an example of shaping in the case of Nordea, when the core element "profitability prioritized over growth" transformed into a new shape ("efficient capital management") in 2003. At that time one of Nordea's core elements underwent a major change while the core element's relationships with one another continued to have a fit-like character. During the strategy development process the CEO of Nordea emphasized that one of short-term top priorities for the bank was to ensure capital efficiency, and the bank took some actions to strengthen its capital efficiency through divestments of real estate and other non-core assets, whereas earlier profitability was prioritized over growth. My perception is that this change can be better characterized as "emergent" rather than "designed," although the core element's identity (focus on profitability) was maintained the same.

Some scholars suggest that organizational change can be both adaptive and disruptive and over time, the same forces that make organizations inert can also make them more malleable (Amburgey, Kelly, \& Barnett, 1993). Organizational changes immediately increase the risk of organizational failure, and this immediate effect declines over time. My findings show that Nordea has had a good strategic fit in its business strategy and the bank has developed its strategy in a way that the risk of organizational failure has been at a lower level, and thus my findings are consistent with the conclusions of Amburgey et al. (1993). By using shaping, the strategic executives of Nordea could generate qualitative changes in the core elements of Nordea's business strategy, and the identity of the core element was maintained the same; the new core element included the content of the earlier core element, but it was broader than the earlier core element. My perception is that this way of developing a business strategy decreases the risk of organizational failure, 
and therefore developing the business strategy of a company by shaping may be in many cases the best way to take into account the optimal risk/reward ratio.

Shaping also makes a wider set of developmental paths possible than Siggelkow (2002) recognized. He identified four ideal types: patch-by-patch development, thinto-thick development, punctuated equilibrium development, and a liner progression development. Each of these ideal types refers to different patterns in creating (and deleting) core elements and the elaborating elements around them. In a patch-bypatch developmental path an organization develops purely by patching and over the organization's history it creates numerous core elements. Whereas in the thin-tothick path an organization has, according to Siggelkow (2002: 153), "founded a number of core elements that it continues to elaborate over time" and "no new core elements are added later." During the thin-to-thick developmental path the core elements stay invariant, but an elaborating element can still change over time. Yet none of these four ideal types characterizes Nordea's development path accurately. Rather, what took place at Nordea was the transformation of the core elements without the changes in the elements' structure that would characterize the ideal types recognized by Siggelkow. Therefore I call the developmental path that happened in Nordea the "shape-to-new-shape" path, in which the identity of a core element maintains its links to other core elements and elaborating elements, yet there are still substantial changes to the core element.

According to Siggelkow (2002: 154) "as long as the core elements within an organizational system remain consistent with each other, both patch-by-patch and thin-to-thick developments can lead to configurations with increasingly tighter interactions, i.e., high internal fit." My perception is that also shape-to-new-shape development can lead to configurations with more and more tight interactions (high internal fit), although the elements within the organizational system do not remain consistent with each other. The essential point is that in shape-to-new-shape development the identity of the core element and its links to other core elements and elaborating elements remain the same, even though the core element changes in a substantial way. In this kind of development firms do not need to move from one set of consistent core elements to another set of core elements, and so the risk level of the strategy development process stays at a lower level. 
Siggelkow pointed out in his study that "the question of when and how firms modify their core element cannot be addressed with the present study" (Siggelkow, 2002: 157). He pointed out as well that although the previous literature on punctuated equilibrium would suggest that when corporates change their core elements, the process is quick and wide-encompassing, future research should study whether (and if so, when) such a process takes place. How a firm modifies its core elements over time is an interesting research gap and my finding (shaping) provides one solution for this academic problem. Shaping is the process of transforming an existing core element into a new shape over the course of time when the core elements within an organizational system remains consistent with each other, and it can lead to high internal fit. Shaping makes it possible for a firm to be reformed without damaging the fit among the core elements of the company.

When using organizational-system maps to understand strategy development, the fit between elements is a central question. However, without shaping as a fifth element, one could mistakenly perceive that the only way to develop an organization is to add, move, or delete elements. But this does not need to be the case. An organization can transform radically without messing around with the relationships between the elements, if it shapes the elements instead. Even so, looking at the process through organizational-system maps enables seeing if the elements continue to fit with one another; that is, shaping is constrained in the sense that it should not change the elements so radically that it destroys the relationships.

In the previous studies it is suggested that mixing and matching in an activity system is an important mechanism from a strategic renewal point of view (Ethiraj \& Levinthal, 2004; Galunic \& Eisenhardt, 2001; Karim, 2006; Martin \& Eisenhardt, 2010; Sanchez \& Mahoney, 1996). The key conclusion was that some modules can mix with other modules and in this way create a new module. One scholar has used the term "recombination," considering it suitable because it implies that the module recombines with other parts within the system (Adler, 2013). These studies have focused on a firm's activity domains and analyzed the mixing and matching of modules in the process of strategic renewal. My study has focused on a firm's organizational system and core elements in the system. Especially I have focused on analyzing the processes that allow companies to evolve toward fit. 
Siggelkow (2002: 157) pointed out in his study that "an interesting observation from the Vanguard case is that Vanguard adopted all of its core elements within four years of its founding." My perceptions from the Nordea case support this view, although during the study period Nordea's strategic core elements transformed many times into a new shape. Siggelkow suggested that one possible factor for firms to adding (or not adding) new core elements in their evolution toward a configuration could be the volatility of the environment and whether environments that are more stable would be more receptive to the coincidental creation of whole set of core elements. My observations do not support his presumption because the study period of the Nordea case (2000-2011) captured economic growth, the globalization and digitalization of the banking industry, the global financial crisis of 2008, the recovery from 2009 to 2010, and the new financial crisis-the Eurozone Debt Crisis in 2011and still the identity of Nordea's core elements remained the same.

My conclusion is that shaping strategic core elements is an essential way through which companies maintain fit between their core elements and yet also transform and grow radically during volatile and turbulent periods in the environment. Therefore my findings are essential for the research on the processes that allow companies to evolve toward fit.

\subsection{Connecting the Design School and strategy emergence}

A second key way my study contributes to the strategy literature is by showing how the analytical tools that were dominantly developed to describe strategies from the design perspective can be merged with ideas relating to strategy emergence. Shaping is a process where changes in the strategy emerge through incremental actions that transform the organization. Yet, shaping is controlled and constrained by the designed organizational system.

Many studies focusing on strategy emergence (e.g., (Mintzberg \& McHugh, 1985; Plowman et al., 2007) describe the process to be a relatively chaotic one in the sense that things just seem to happen and a consistent pattern can only be discerned retrospectively. However, my description of the Nordea case (using organizational-system maps) allowed me to see how the strategy emergence 
happened within the constraints of the organizational design-by shaping the elements that constitute the organization.

On the other hand, more design-focused studies highlight that the selection of key elements is essential and that performance increases can mainly be achieved by changing the key elements or rebuilding their relationships. However, the shaping perspective highlights the learning and emergent developments that happen within the elements. A proper analogy could be a football team: The positions of the players need not change, a quarterback can remain a quarterback. Yet, a team can become radically more effective by shaping its players: the players can develop new skills that allow them to carry out more actions on the field and perform better.

It is critical for the successful shaping of core elements that the top management of a company can identify potential core elements and that they have ability to engineer the mindful and smart emergence of these potential core elements. In the case of Nordea some core elements were shaped when it was realized that the industry development requires changes in the course of actions. The process of shaping was partly an emergent way to understand and recognize new business opportunities. My study suggests that top management's ability to engineer mindful and smart emergence can be one variable that makes a bank different and more successful.

In the beginning of Nordea's history (in 2000) the basic idea was to create a Nordic bank, which would have a strong market position in the Nordic countries in particular. According to my interviews there were different views and tensions among the top management because some of them wanted to focus on building of the Nordic banking concept and some had the aim to create a European bank. The previous Chairman of the Board had the aim to create a European bank, but the new Chairman of the Board wanted to concentrate on creating a strong Nordic bank. This situation was realized when the top management of Nordea was considering a potential merger with ABN AMRO.

As March and Simon (1958) argued, it is important to take into account the motivational, attitudinal, and rational aspects of human behavior when studying human behavior in an organization. What was the reason that one of the key decision 
makers was strongly against the transaction with ABN AMRO, a Dutch bank, although the majority of the top management supported the deal? The main reason was of course that a few years earlier, when Nordea was created, the basic idea was to create a strong Nordic bank, but according to my interviews the key decision maker also had a personal interest to be against merging with ABN AMRO. This personal interest was to keep his strong power base in Sweden and therefore he was against the deal.

The Board of Directors at Nordea decided to keep the core element in the shape of "the Nordic countries as a home market," and it did not continue the merger talks with ABN AMRO. But three years later, Nordea's core element "the Nordic countries as a home market" turned into "a focus on the Nordic region as well as new European markets." It meant that Nordea had a new strategic focus to not only focus on the Nordic countries as a home market, but also to create value through organic growth in the Nordic region as well as in new European markets. The background for this new strategic stance was that Nordea had implemented the same strategy for five years and when the new CEO took the helm in 2007, the organization was waiting for something new, such as the new speed of expansion. Through the new CEO the organization reached a new level of aspiration, even though the CEO did not make any big changes to the business strategy of Nordea. This development process of the strategy was more a question about shaping the core element rather than making big changes all at one time, and the key decision makers' personal interests and aspirations also impacted on the decision-making process.

During the time of the internet bubble (in 2000), it was very typical in the banking industry to put a lot of focus on developing internet banking. Also Nordea pointed out that the internet continued to change the world of financial services and the bank wanted to be a forerunner in this development process and intended to maintain leadership in developing wired and wireless services to its customers via the internet. During this time "a focus on e-banking" was one of the core elements in Nordea's business strategy. But at the same time, most of the leaders in the top management at Nordea did not believe that successful e-banking was possible without any physical branch network. Later the core element "a focus on e-banking" took on the new shape "a multi-channel distribution network," and Nordea aimed to strike an 
optimal balance between personal and electronic services in its multi-channel distribution network. As a part of this strategy Nordea wanted to provide top-ranking e-banking services for its customers, and e-banking developed step by step into a multi-channel model.

My perceptions support the findings of other scholars (Van Ees, Gabrielsson, \& Huse, 2009) when they emphasized that while decision-making in corporate governance represents a coalition of members, diverse interests may dominate over problems of conflicts of interest, exploitation, and the creation of value. Based on my findings it is very interesting that in the case of Nordea, although there were different views and aspirations among the bank's top management and board, it seems to be that the shaping of the strategic core elements was in most cases the final result, without needing to simultaneously make more radical changes in the business strategy of the bank.

\subsection{Contributions to the understanding of the banking industry}

My findings contribute in several ways to the research on understanding the banking industry. Previous studies (e.g., Ayadi et al., 2011) found that retail banks are the institutions that are the least leveraged and had taken risks whilst still performing comparably with their peers. This study pointed out as well that the retail banking model is safer than the others. The findings of my study support this conclusion because Nordea focused on retail banking and its profitability (the development of net profit) was very stable for the whole study period (2000-2011), particularly when compared with its peers. In comparing Nordea with its peer group banks, which focused more on investment banking, their profitability and ability to create total shareholder value was clearly on a lower level than that of Nordea. In the first phase of my data analysis, I found that most of the best performing banks among the study group focused on retail banking (e.g., Danske Bank, HSBC, and Santander). These banks had less volatility in their profitability, and my findings support the previous studies' conclusions that retail banks were the financial institutions that had taken less risks and yet had performed comparably with their peers. 
Local banking regulations can create barriers to the entry of foreign banks. One study concluded that when a retail bank is entering into a foreign market, it can face three critical challenges: a lack of a good local brand and reputation, a lack of ability to reach a large enough customer base within reasonable timescale, and a lack of local market knowledge (Petrou, 2009b). However, Nordea is the result of the merger (between 1997-2000) of four local, leading banks in Scandinavia: Merita in Finland, Nordbanken in Sweden, Unidanmark in Denmark, and Christiana Bank in Norway. Nordea is unique because it covers all the Nordic countries. In the beginning the new bank's market share of banking assets in different countries varied from $15 \%$ in Norway to $40 \%$ in Finland. Therefore the bank had a good local reputation, it achieved a large enough customer base within a reasonable timescale, and it had a good knowledge of the local market. Its biggest challenge was to implement a new brand name, Nordea, and to create a common way to serve customers as well as to create a common corporate culture in the bank.

According to one study the fundamental challenge of internationalization in the banking industry is how to achieve economies from cross-border integration when the production of services is highly decentralized. This challenge is even greater in retail banking because of local regulation (Parada et al., 2009). In the banking literature an example of a successful cross-border merger is MeritaNordbanken (Flier et al., 2001a). MeritaNordbanken is the original parent company of Nordea. The case of Nordea has been a pioneering case of the merging process between leading retail banks (which were operating in four different countries) in the European banking industry (Vaara et al., 2005). Although the case was a pioneering case, the news of the Nordea merger was reported both excitedly and skeptically in the Nordic business media (Soderberg \& Vaara, 2003).

Why are some banks consistently more profitable than others? What are key competitive advantages in the banking industry? Ajay Mehra (1996) defined 10 key resources that provide a sustainable competitive advantage in the banking industry. My findings support Mehra's analysis and conclusions. "Management quality and depth" has clearly been one of Nordea's competitive advantages. The bank also had a wide branch network ("franchise") and it was a forerunner in e-banking ("technological expertise"). "Efficiency" is a key element in a successful banking 
business and a technologically advanced bank has better capabilities to improve its efficiency by using new technological solutions. Nordea focused on "risk management and credit quality." Efficient capital management has been one of the key elements in Nordea's business strategy ("the adequacy of the capital base"). Nordea has focused on efficiency and developed the cross-selling of banking services, and Nordea has tried to achieve a deepening partnership with customers ("efficiency" / "information asymmetries").

There was only one of the key resources defined by Mehra that Nordea was missing. It was "placing power." Nordea had an investment banking unit, but Nordea was not the best investment bank and it did not have the best placing power in the Nordic area. In investment banking the economies of scale work because strong placing power can be a competitive advantage and a number of clients are multinational corporations, which need similar services in different markets. Usually the financial service needs of multinational corporations tend to be globally homogeneous. Also, the transfer of specialized knowledge can create a competitive advantage to a bank. Furthermore, my study suggests that Nordea was successful not only because it had most of these listed elements, but also because it successfully managed the different elements to maintain a fit between them. In particular, Nordea shaped many of the elements in a way that maintained internal fit as it adapted to the changing industry landscape (external fit).

My findings support the view that the management quality and depth of a bank's management is the most critical resource in the creation of a sustainable competitive advantage. A competent top management, as Nordea has, formulates a consistent strategy for the bank and the systematic implementation of the strategy ensures a sustainable financial performance for the bank. Nordea is also a good example of a case when a clear strategic vision is a key element in the succession of a firm. According to Porter (1996), strategy is the creation of a unique and valuable position, involving a different set of activities. The essence of strategy is in choosing what not to do, and trade-offs are essential to strategy. In the case of Nordea, the bank has had a very clear focus over the studied period, which has included choices about what not to do. One top manager of Nordea pointed out that since 2001 it was really easy to continue to implement the bank's strategy because the whole top 
management of the bank had a clear and common vision of the bank's future (top manager, 2014).

Porter (1996) has pointed out that companies must continuously be flexible in order to respond to all the changes in their competitive landscape and that benchmarking is a best-practice method to achieve it. When Nordea was transforming its strategic core elements into new shapes, it was flexible in responding to changes in its competitive landscape. Petrou (2009) argues in his study that banks do not pursue the same entry strategy consistently and banks' choices of strategy are tailored to environmental realities. That was also the case with Nordea, when for example the bank transformed its core element "a focus on Nordic countries" into a new shape.

The previous studies on mergers and acquisitions have continually explained and described problems and failures by focusing on post-merger integration. These studies have included analyses of value creation (Haspeslagh \& Jemison, 1991; Larsson \& Finkelstein, 1999; Schweizer, 2005; Shaver, 2006) as well as analyses of the cultural challenges in international mergers and acquisitions (Buono \& Bowditch, 1989; Olie, 1994; Stahl \& Voigt, 2008; Vaara, 2002). Some scholars have shown how "discursive legitimation" is a key element of the merger process (Vaara \& Monin, 2010; Vaara, Tienari, \& Laurila, 2006; Vaara, Tienari, \& Santti, 2003). It is generally known that mergers and acquisitions often fail to deliver the synergy and other strategic objectives set for them, but my findings show that in the longer run mergers and acquisitions can, however, create value and benefits that are difficult to estimate beforehand. There are different explanations for the poor performance of mergers and acquisitions, for instance, the overestimation of cost and income synergies, organizational resistance, cultural differences, and the different political games within and around the merging organizations. According to one study cultural mismatch is one of the important reasons why mergers fail (Zaheer, Schomaker, \& Genc, 2003), and particularly in cross-border mergers, cultural issues usually create a great challenge to shareholder value creation and success. According to one study corporate culture is an important driver of the success of mergers and acquisitions (Sirmon \& Lane, 2004). In the case of Nordea there were naturally cultural differences between the four banks from four different countries. For example Merita had been a bank with more hierarchy in its organization. 
The case of Nordea was a particularly interesting case for analyzing post-merger integration, because it was a forerunner in the restructuring of the European (Nordic) retail banking industry. A group of Nordic management scholars have made an indepth study on the formation and organization of Nordea in its early stages (Soderberg \& Vaara, 2003). There are also other different publications in which these scholars have studied various issues about Nordea relating to cultural differences, language, power, integration, and learning. Nordea was created through three subsequent cross-border mergers and acquisitions involving Swedish, Finnish, Danish, and Norwegian banks between 1997 and 2000. After the merger between MeritaNordbanken and Unidanmark in 2000, the rapid integration of Nordic business was the name of the game. The target was that the first nine months of merger integration would establish a new business organization with six business areas, supported by a corporate center and group staff (Nordea Annual Report 2000: 2627).

When I was analyzing changes in Nordea's activity system, and particularly its integration process, I realized that Nordea's core element "the rapid integration of Nordic businesses" transformed into a new shape. This core element was transferred into "an integrated banking group," which really meant speeding up integration and unification. This was the agenda of Nordea's new (at the time) CEO, Lars G. Nordström (Nordea Annual Review 2002: 9). My conclusion is that this shaping process of the core element is a good example of an efficient way to integrate merging companies without of high level of failure during the integration process. Shaping refers to a process that maintains the identity of a core element (integration) and its links to other core elements and elaborating elements, yet changes the core element in a substantial way.

My findings show that the top management of Nordea had the overall intention and objective to build one strong Nordic financial services group. My conclusion is that although cross-border mergers have several kinds of challenges in the short term, in the long run a cross-border merger in the retail banking industry can be successful if there is a good strategic fit and consistent business strategy over the time. In this study the success of a bank is measured by the relative development of TSR. My 
findings support one previous study that analyzed the case Nordea and concluded that "organizational storytelling is characterized by polyphonic, stylistic, chronotopic, and architectonic dialogisms and by a dynamic between centering and decentering forces" (Vaara \& Tienari, 2011). Nordea's President and CEO, Hans Dahlborg, started this storytelling when he wrote in his letter to shareholders that

the business rationale for a Nordic financial services group is the rapid integration of Nordic businesses concerning all walks of life. In the Nordic countries, people are similar enough to be able to co-operate, different enough to benefit from learning from each other and numerous enough to provide an interesting home market. Hence, in Nordea, we share and exchange Nordic Ideas. (Nordea Annual Report 2000: 6)

This was the start of the construction of a Nordic identity that would include avoiding national confrontation and create a meaningful basis for common Nordic culture and positive images related to Scandinavian and Nordic countries. The new brand name came from combing the words "Nordic" and "idea," to get Nordea. Nordea launched the new brand name by a wide marketing campaign in Nordic newspapers and magazines as well as by targeted advertising in international media.

One study analyzed the integration process of Nordea and suggested that "a strategy of locating and transferring knowledge around best practices can, at best, be an effective integration mechanism in merging multinational organizations" (Vaara, Tienari, \& Björkman, 2003). My findings suggest that (particularly in the long run) focusing on best practices can be an effective integration mechanism, especially in cross-border mergers, and it can also lead to valuable innovations in doing things in a new best way. The exchange of best practices and products was a key element of the integration process in Nordea. However, particularly in the early stages of integration there were difficulties in identifying which practices were the best practices. It seems to be a link between cultural fit and activity fit, and sometimes the problems of activity fit looked more like cultural problems.

The previous banking literature has focused on the strategy design process and planning. Scholars have argued that strategic planning is more and more important in the banking industry and in response to increasing complexity and continuous changes in the global financial industry, banks have turned to strategic planning (Hopkins \& Hopkins, 1997). It has also been suggested that in services industries like 
the banking industry, where competition can move very quickly and new players can enter easily, there is a constant need to think strategically about what is going on (e.g., Schmenner, 1995). However, my findings about the successful bank, Nordea, highlights that in understanding strategy as a constellation of organizational elements it is not sufficient to focus on the relationships between the elements, one must also be mindful of the qualitative nature and changes in the elements themselves. These changes are better characterized as "emergent" rather than "designed." Some core elements of Nordea's business strategy were shaped when it was realized that the industry's development required changes in the course of actions. Therefore my conclusion is that a bank's ability to engineer mindful and smart emergence can be one success factor that makes the difference between a winner and a loser among banks.

\subsection{Managerial implications}

I have more than twenty years experience of working in top management positions in the banking industry. This background helped me to familiarize myself with the data of banks and to analyze them, and it also made it easier for me to find core and critical elements of the studied bank's organizational systems and business strategies. Nordea was one of the main competitors for my previous employer during my banking career, and therefore at the beginning of my study I already had a deep understanding of the bank's history and strategy.

During my study, especially considering its iterative mode, I made many crucial observations from top management's point of view. My findings highlight that managers should not consider the elements of their organization as fixed entities but as malleable ones. That is, managers should recognize that the elements may be shaped and that such shaping may be the best way to transform their organization. Such an approach can help them to avoid two extremes: rigidity and changing too much. Rigidity results when managers make no changes to their organization. Conversely, transforming the element structure might be too radical and expose the organization to many risks, destroying too many routines and creating too many new problems. Shaping allows change, yet maintains important routines that are material manifestations of the interconnections between elements and the consequent fit. 
From top management's point of view it is critical to understand and recognize the bank's activities and organizational structure extremely well so that they have the ability to make the right decisions in order to transform the bank's strategic core elements into new shapes. When they are shaping core elements they also have to take into account the firm's capability to ensure the success of the change.

When organizations can be modeled as a system, a map can show how a company's strategic position is included in a set of tailored activities designed to deliver it. The strategic organizational-system map provides a useful way to visualize an organizational system. My recommendation is that companies should use more of this kind of model when they are developing their business strategies and identifying the core elements of the strategy. Zott and Amit (2010) concluded that the activity-system perspective encourages managers to think more systemically and holistically when they are designing their business model. My findings support their conclusion.

It is important to understand the performance of a firm as a system of interconnected choices in a firm. It is crucial both for organizations and theory, and the existing research does address this issue in a way that is complete which doesn't support the argument. In my research the theoretical sampling is appropriate because the case of Nordea is particularly suitable for demonstrating and extending the relationship and logic among concepts. The internal fit between choices can lead to a sustainable competitive edge because it makes imitation difficult for rivals (Rivkin, 2000). Therefore this research question is also a critical managerial question.

Upper echelon theory suggests that strategic decisions are too rarely based on rational analysis, but rather on executives' personal motives and past experiences (Hambrick \& Mason, 1984). This kind of personal motive can be individual financial and reputation gains for example. According to one study the leaders in financial services internationalization have been the companies with the strongest commitments to growth; typically banks have been led by high-profile CEOs who are committed to transforming their companies into regional or global giants. According to one study, Sandy Wells at Citigroup, Ken Lewis at Banc of America, and Richard Fuld at Lehman Brothers all built the corporate strategies of the firms they managed 
around their ambitions (Grant \& Venzin, 2009). My results support this conclusion and in my research sample the case of RBS is a good example of that when a growth-driven CEO heads a bank and its home market is too small for growth. The result of this development was a spectacular international expansion with a huge increase in the risk level of the bank's business portfolio. What are the lessons learned from the case? Good corporate governance is particularly important in the banking industry, and the board of directors in a bank should take into account this kind of risk when it is making strategic decisions about mergers and acquisitions.

One study of international banking concluded that foreign activities are less profitable than domestic activities and that banks that increased their internationalization activities (either strongly or moderately) generated the least total shareholder value (Slager, 2004). Another study confirms that among five leading European banks, there was no consistent relationship between internationalization and profitability between 2000 and 2004 (Venzin et al., 2008). In the EU, the banking industry has found only a little improvement in cost efficiency or profitability through cross-border mergers and acquisitions, and in-country banking mergers have been significantly more successful than cross-border mergers (Ayadi \& Pujals, 2004). Internationalization creates no value without cross-border integration or know-how transfer by exchange practices.

Economies from centralized administrative services have seen important anticipated benefits from cross-border mergers and acquisitions in the banking industry. My findings support the perception that internationalization creates no value without cross-border integration or know-how transfer through the exchange of best practices. In particular, retail banking is a local business and therefore the potential access to cost economies by the international integration of functions or activities is limited. There are some functions with huge cost-savings opportunities, for instance IT systems where one IT platform can create huge cost-savings opportunities. In my study Nordea is a good example of a bank that purposefully tried to implement a one IT platform model.

"The rapid integration of Nordic businesses" and building "an integrated banking group" were core elements in the business strategy of Nordea. "The adoption of best 
practices," "harmonizing customer concepts," and "products and distribution channels are coordinated and integrated," were key actions in the rapid integration process. "The transfer of specialized knowledge" might well have created a competitive advantage for the bank. Nordea has actively put a lot of focus on the integration processes in its business strategy and the core element of integration has transformed many times into new shapes over the studied period. My conclusion is that in particular the focus on integration has been a key driver for the successful cross-border merger in the case of Nordea. The rapid integration was part of a skillfully managed (high fit) activity system that thus enabled the successful crossborder merger. These perceptions are useful for the top management of a bank when a bank is creating and developing its new growth strategy.

I made my preliminary analyses on 25 major listed European banks, and their business strategies and performance from 2000 to 2011. By definition my sample of banks in the European banking industry included different countries and all of them were among the largest European listed banks by market capitalization at the beginning of 2001 . When I made the preliminary analyses I realized that the best performers had better strategic fit in their business strategies and their business strategies were more consistent over time. The best performers developed their business strategies more by shaping the core elements of the business strategy than by changing them radically all at one time. The worst performers among the studied banks did not have a good strategic fit and some of them made radical changes in their business strategies during the studied period. According to my results the best performers in the study group (according to TSR) between 2000 and 2011 were Standard Chartered $(+158.1 \%)$ and Nordea $(+114.1 \%)$, when the average TSR for the studied banks was $-23.3 \%$. The worst performers in the study group during the same period (according to TSR) were Commerzbank (-94.7\%) and RBS (90.1\%).

RBS made the successful acquisition of NatWest in 2000 and then the bank decided to accelerate its growth strategy and create one of Europe's largest banking groups. During the 1990s capitalization of the RBS Group had increased from $£ 1.2$ billion to $£ 42.4$ billion and the top management of the bank had strong self-confidence when they set the new target of becoming one of the leading banks in Europe. The Chairman of RBS pointed out in the group's annual report in 2000 that the bank had 
been the only UK bank to have also been consistently successful in the US market (with 17 acquisitions), and that it had been the fastest growing bank in the UK (RBS Group Annual Report 2000: 2). Over the following years RBS grew rapidly through acquisitions, including many in the US market. Also, its international investment banking activities grew quickly in the years preceding the global financial crisis of 2008 due to numerous acquisitions, including Charter One in the US (2004) and ABN AMRO (2007), and a partnership with the Bank of China (2005). The RBS Group's acquisition of ABN AMRO's wholesale and trading activities is the principal driver of the bank's transition from a traditional bank in 2006 into an investment bank during 2008 and 2009. The average total assets growth rate of RBS was $18.7 \%$ between 2000 and 2011 while the average total assets growth rate of the peer group was $11.8 \%$ for the same period. During the global financial crisis RBS received massive liquidity and capital support by the UK government and the UK central bank. The main reason for the aid was that the bank had a high dependency on wholesale funding as well as losses on structured assets (in investment banking), and higher credit risks generally. The RBS Group also made huge goodwill write-downs on acquisitions (e.g., in 2008 these totaled $£ 14.8$ billion).

My conclusion is that RBS is a good example of a bank that made radical changes in its business strategy when it decided to accelerate its growth strategy and targeted becoming one of the largest banks in Europe as well a big player in investment banking globally. My findings show that RBS developed its strategy less by shaping its strategic core elements and more by making big changes all at one time. Thus the risk of organizational failure was at a higher level, and this perception supports the conclusions of Amburgey et al. (1993).

Internet banking constitutes an important innovation in the financial industry. Internet banking allows banks to reduce costs through the exploitation of economies of scale and scope, to strengthen their market position by providing value-added services to the current customers, and to operate in new markets by attracting new customers (Corrocher, 2006). Channel integration is a significant, but at the same time challenging, component of fulfillment. A typical pitfall for banks and other companies is that when they add a new channel to their business system, it is often another siloed operation with its own separate systems and processes. My study pointed out 
that focusing on e-banking was the case early in 2000 , but that later on successful banks like Nordea focused not only internet banking but more and more on a multichannel distribution network that includes both e-banking and branches with other potential service channels.

My conclusion is that technological expertise is a key resource in the banking industry, because banking is an information intensive industry. Efficiency is a key element of a successful banking business and a technologically advanced bank has much better capabilities to improve its efficiency by using new technological solutions. Innovations are important in the creation of a new process or technique that provides value-added services effectively to bank's clients. The positive relationship between size and adoption of innovations in the banking industry is generally explained in terms of economies of scale. By offering innovative services a large bank can reduce its average costs much more than a smaller bank, because a larger bank's number of customers and financial transactions are at a higher level (Corrocher, 2006).

It is interesting that the previous literature does not support the hypothesis that there would be a significant relationship between the profitability of a bank and the adaption of new technologies (e.g., Pennings \& Harianto, 1992). One of the reasons might be that the fit of the new technology with the overall activities of the bank can influence the impact of the technology. Nordea did not maintain e-banking as a separate entity but shaped e-banking into multi-channel distribution, and thus integrated e-banking into its activity system in a fit-enhancing way. This was a significantly more cost-effective and efficient way to integrate the new distribution channel into the bank's overall distribution network. Nordea's way of shaping its ebanking strategy into multi-channel distribution pushed the bank's costs down as customers increasingly used automated channels and obtained a similar service.

When I analyzed the business strategies of the major European banks, I found some pitfalls or deadly sins that were typical of the worst performing banks. These deadly sins were as follows: a bank grew too quickly_cheap funding increased the leverage and risk-taking in the bank; a bank grew by the aggressive acquisition in foreign markets; a bank made acquisitions in the US market in the wrong business and at 
the wrong time; a bank made large acquisitions with high valuation multiples, especially between 2005 and 2007; a bank had an active role in the securitization and mortgage-backed securities market; a bank had a strategic focus on investment banking; or a bank had a large exposure in Greek and other peripheral bonds when the Eurozone debt crisis started. Nordea, one of best performers in the study group, avoided all of these pitfalls in its business strategy.

According some scholars (Adrian, 2008) short-term interest rates are determinants of the cost of leverage and are found to be important in influencing the size of financial intermediary's balance sheets. In the early 2000s retail deposits in Europe grew roughly in line with EU GDP and did not allow bank balance sheet growth to outpace GDP growth. European banks instead funded their rapid growth with funding in the interbank markets (unsecured) and wholesale repo markets (secured) (Liikanen, 2012). I found that some banks in the study group grew too quickly, and cheap funding in particular increased leverage and risk-taking in the bank. RBS was a good example of the fastest growing banks in the study group.

\subsection{Limitations and future research}

In contrast to what the previous theory would suggest, I found that the company's core elements themselves underwent major changes through a process that I call shaping, during which the elements' relationships between one another continue to have a fit-like character. My findings highlight that to understand strategy as a constellation of organizational elements, it is not sufficient to focus on the relationships between the elements, one must also be mindful of the qualitative nature and changes in the elements. To understand the process of shaping in more detail, it is necessary to study the process and its existence in many different companies (for example in a multi-case study), in different industries (my study was only in the banking industry), and in different phases of a company in its development path (my study focused on a company that was newly formed after a cross-border

merger), because our understanding of fit's developmental process is still fragmented, and perspectives that put more emphasis on emergence and behavioral aspects could further inform the study of how organizations develop strategic fit over time. 
It is necessary in future research to analyze and study in more detail the impact that changes in a company's business environment have on the way in which the company develops and maintains its strategic fit.

While my study indicates that shaping is associated with high performance, in strict terms my data only supports the qualitative description of the shaping process. In my study I only focused on one company, one corporate culture, and one industry. Large sample studies are needed to test the performance implications. This larger sample should include many companies with different corporate cultures and from different industries.

While I recognized that shaping happens in the boundaries created by an organizational activity system, I did not study in detail how managers recognized the limits within which the elements can be shaped. Managers might use different approaches to make sense of how much shaping they can do. Future research should investigate this.

Other characteristics of the micro-level processes relating to shaping should also be studied further. While I had some interview material, a richer description the decisionmaking processes that relate to shaping could add more insight on the factors that influence shaping. 


\section{REFERENCES}

Adrian, T., \& Shin, H. S. 2010. Liquidity and leverage. Journal of Financial Intermediation, 19(3): 418-437.

Adrian, T. a. H. S. 2008. Financial Intermediaries, Financial Stability and Monetary Policy, The 2008 Federal Reserve Bank of Kansas City Symposium Jackson Hole, USA.

Albert, D. 2013. Strategic Renewal of Activity Systems. An Interdependency Perspective. Unpublished Doctoral Thesis, University of St. Gallen, St Gallen, Switzerland.

Aldrich, H. E. 1979. Organizations and Environments. Englewood Cliffs, NJ: Prentice-Hall.

Alessandri, P., \& Haldane, A. 2009. Banking on the State. London.

Alvesson, M., \& Karreman, D. 2007. Constructing mystery: Empirical matters in theory development. Academy of Management Review, 32(4): 1265-1281.

Alvesson, M., \& Sandberg, J. 2011. Generating research questions through problematizationa. Academy of Management Review, 36(2): 247-271.

Amburgey, T. L., Kelly, D., \& Barnett, W. P. 1993. Resetting the Clock - the Dynamics of OrganizationalChange and Failure. Administrative Science Quarterly, 38(1): 51-73.

Ashkenas, R. N., DeMonaco, L. J., \& Francis, S. C. 1998. Making the deal real: How GE Capital integrates acquisitions. Harvard Business Review(76): 165-178.

Astley, W. G. 1985. Administrative Science as Socially Constructed Truth. Administrative Science Quarterly, 30(4): 497-513.

Ayadi, R., Arbak, E., \& De Groen, W. P. 2011. Business Models in European Banking - A Pre- and PostCrisis Screening: 104. Brussels, Belgium: Centre for European Policy Studies.

Ayadi, R., \& Pujals, G. 2004. Banking Consolidation in the EU - Overview and Prospects. Brussels, Belgium: Th Centre for European Policy Studies.

Bailey, J. R. E. 2002. Retracting reflection: Views from the inside. Academic of Management Executive, 1(1): 77.

Barkema, H. G., Bell, J. H. J., \& Pennings, J. M. 1996. Foreign entry, cultural barriers, and learning. Strategic Management Journal, 17(2): 151-166.

Barney, J. B. 1988. Returns to Bidding Firms in Mergers and Acquisitions - Reconsidering the Relatedness Hypothesis. Strategic Management Journal, 9: 71-78.

Barney, J. B. 1991. Firm resources and sustained competitive advantage. Journal of Management, 17: 99120.

Barr, P. S., Stimpert, J. L., \& Huff, A. S. 1992. Cognitive Change, Strategic Action, and Organizational Renewal. Strategic Management Journal, 13(Summer Special Issue): 15-36.

Baum, J. A. C., \& Mezias, S. J. 1992. Localized Competition and Organizational Failure in the Manhattan Hotel Industry, 1898-1990. Administrative Science Quarterly, 37(4): 580-604.

Baum, J. A. C., \& Singh, J. V. 1994. Organizational Niches and the Dynamics of Organizational Founding. Organization Science, 5(4): 483-501.

Baumol, W. J., Panzar, J. C., \& Wilig, R. P. 1982. Contestable markets and the theory of industry structure. New York: Harcourt, Brace and Jovanovich.

Berger, A. N., Hasan, I., \& Zhou, M. 2010. The effects of focus versus diversification on bank performance: evidence from Chinese banks. Journal of Banking \& Finance, 34(7): 1417-1435.

Berger, A. N., Humphrey, D. B., \& Pulley, L. B. 1996. Do consumers pay for one-stop banking? Evidence from an alternative revenue function. Journal of Banking \&amp; Finance, 20(9): 1601-1621.

Bettis, R. A., \& Hitt, M. A. 1995. The New Competitive Landscape. Strategic Management Journal, 16: 719.

Beyer, J. M., \& Trice, H. M. 1982. The Utilization Process - A conseptual -framework and synthesis of empirical-findings. Administrative Science Quarterly, 27(4): 591-622.

Brown, S. L., \& Eisenhardt, K. M. 1997. The art of continuous change: Linking complexity theory and timepaced evolution in relentlessly shifting organizations. Administrative Science Quarterly, 42(1): 134.

Bruton, G. D., Oviatt, B. M., \& White, M. A. 1994. Performance of Acquisitions of Distressed Firms. Academy of Management Journal, 37(4): 972-989.

Buono, A. F., \& Bowditch, J. L. 1989. The Human Side of Mergers and Acquisitions: Managing Collisions between People, Cultures and Organizations. London: Jossey-Bass.

Burns, T., \& Stalker, G. 1961. The Management of Innovation: Tavistock.

Capron, L., Dussauge, P., \& Mitchell, W. 1998. Resource redeployment following horizontal acquisitions in Europe and North America, 1988-1992. Strategic Management Journal, 19(7): 631-661.

Chandler, A. D., Jr. 1962. Strategy and Structure: Chapters in the History of American Industrial Enterprise. Cambridge, Massachusetts: MIT Press. 
Chatterjee, S., Lubatkin, M. H., Schweiger, D. M., \& Weber, Y. 1992. Cultural-Differences and Shareholder Value in Related Mergers - Linking Equity and Human-Capital. Strategic Management Journal, 13(5): 319-334.

Corrocher, N. 2006. Internet adoption in Italian banks: An empirical investigation. Research Policy, 35(4): 533-544.

Cyert, R. M., \& March, J. G. 1963. A behavioral theory of the firm. Englewood Cliffs, CA: Prentice Hall.

Dahlborg, H. 2014. Ansvarets sköna börda. Mina år med Nordea. (First Edition ed.). Falun, Sweden: Albert Bonniers Förlag.

Datta, D. K. 1991. Organizational Fit and Acquisition Performance - Effects of Postacquisition Integration. Strategic Management Journal, 12(4): 281-297.

Datta, D. K., Pinches, G. E., \& Narayanan, V. K. 1992. Factors Influencing Wealth Creation from Mergers and Acquisitions - a Metaanalysis. Strategic Management Journal, 13(1): 67-84.

De Jonghe, O. 2010. Back to the basics in banking? A micro-analysis of banking system stability. Journal of Financial Intermediation, 19(3): 387-417.

Demsetz, H. 1973. Industry structure, market rivalry, and public policy. Journal of Law \& Economics, 16: 110.

DeYoung, R., \& Roland, K. P. 2001. Product Mix and Earnings Volatility at Commercial Banks: Evidence from a Degree of Total Leverage Model. Journal of Financial Intermediation, 10(1): 54-84.

Diamond, D. W. 1984. Financial Intermediation and Delegated Monitoring. Review of Economic Studies, 51(3): 393-414.

Dimaggio, P. J., \& Powell, W. W. 1983. The Iron Cage Revisited: Institutional Isomorphism and Collective Rationality in Organizational Fields. American Sociological Review, 48(2): 147-160.

Dore, R. 2008. Financialization of the global economy. Industrial and Corporate Change, 17(6): 10971112.

Drazin, R., \& Van de Ven, A. H. 1985. Alternative Forms of Fit in Contingency Theory. Administrative Science Quarterly, 30(4): 514-539.

Drew, S. A. W. 1995. Accelerating innovation in financial services. Long Range Planning, 28(4): 1-21.

Eisenhardt, K.M. 1989. Building Theories from Case Study Research. Academy of Management Review, 14(4): 532-550.

Eisenhardt, K. M., \& Martin, J. A. 2000. Dynamic capabilities: What are they? Strategic Management Journal, 21(10-11): 1105-1121.

Ethiraj, S. K., \& Levinthal, D. 2004. Bounded rationality and the search for organizational architecture: An evolutionary perspective on the design of organizations and their evolvability. Administrative Science Quarterly, 49(3): 404-437.

Faust, D. 1984. The limits of scientific reasoning. Minneapolis: University of Minnesota Press.

Feldman, M. S. 2000. Organizational routines as a source of continuous change. Organization Science, 11(6): 611-629.

Fiss, P. C., \& Zajac, E. J. 2004. The diffusion of ideas over contested terrain: The (non)adoption of a shareholder value orientation among German firms. Administrative Science Quarterly, 49(4): 501534.

Flier, B., van den Bosch, F. A. J., Volberda, H. W., Carnevale, C. A., Tomkin, N., Melin, L., Quélin, B. V., \& Kriger, M. P. 2001. The Changing Landscape of the European Financial Services Sector. Long Range Planning, 34(2): 179-207.

Floyd, S. W., \& Lane, P. J. 2000. Strategizing throughout the organization: Managing role conflict in strategic renewal. Academy of Management Review, 25(1): 154-177.

Fowler, K. L., \& Schmidt, D. R. 1989. Determinants of Tender Offer Post-Acquisition Financial Performance. Strategic Management Journal, 10(4): 339-350.

Freeman, L. C. 1979. Centrality in social networks conceptual clarification. Social Networks, 1(3): 215-239.

Fuentelsaz, L., Gómez, J., \& Palomas, S. 2012. Production technologies and financial performance: The effect of uneven diffusion among competitors. Research Policy, 41(2): 401-413.

Gale, B. T. 1972. Market share and rate of return. Review of Economics and Statistics, 54: 412-423.

Galunic, D. C., \& Eisenhardt, K. M. 2001. Architectural innovation and modular corporate forms. Academy of Management Journal, 44(6): 1229-1249.

Gavetti, G., Greve, H. R., \& Levinthal, D. A. 2012. The Behavioral Theory of the Firm: Assessment and Procpects. The Academy of Management Annals, 6(1): 1-40.

Gavetti, G., \& Rivkin, J. W. 2007. On the origin of strategy: Action and cognition over time. Organization Science, 18(3): 420-439.

Gersick, C. 1991. Revolutionary Change Theories: A Multilevel Exploration of the Punctuated Equilibrium Paradigm. Academy of Management Review, 16(1): 10-36.

Glaser, B., \& Strauss, A. 1967. The Discovery of Grounded Theory. Chicago, IL: Aldine. 
Glassman, R. 1973. Persistence and Loose Coupling in Living Systems. Behavioral Science, 18(83-98).

Grant, R. M., \& Venzin, M. 2009. Strategic and Organisational Challenges of Internationalisation in Financial Services. Long Range Planning, 42(5-6): 561-587.

Greenwood, R., \& Hinings, C. R. 1996. Understanding radical organizational change: Bringing together the old and the new institutionalism. Academy of Management Review(21): 1022-1054.

Greve, H. R. 2009. Bigger and Safer: The Diffusion of Competitive Advantage. Strategic Management Journal, 30(1): 1-23.

Hambrick, D. C., \& Mason, P. A. 1984. Upper echelons: The organization a a reflection of its top managers. Academy of Management Review, 9: 193-206.

Hannan, M. T., Burton, M. D., \& Baron, J. N. 1996. Inertia and change in the early years: Employment relations in young, high-technology firms. Industrial \& Corporate Change, 5(2): 503-536.

Hannan, M. T., \& Freeman, J. 1977. The Population Ecology of Organizations. The American Journal of Sociology, 82(5): 929-964.

Hannan, M. T., \& Freeman, J. 1984. Structural Inertia and Organizational Change. American Sociological Review, 49(2): 149-164.

Hannan, T. H., \& McDowell, J. M. 1984. The determinants of technology adoption: the case of the banking firm. RAND Journal of Economics (RAND Journal of Economics), 15(3): 328-335.

Harrison, J. S., Hitt, M. A., Hoskisson, R. E., \& Ireland, R. D. 1991. Synergies and Postacquisition Performance - Differences Versus Similarities in Resource Allocations. Journal of Management, 17(1): 173-190.

Haspeslagh, P. C., \& Jemison, D. B. 1991. Managing acquisitions - Creating value through corporate renewal. New York: The Free Press.

Haunschild, P. R. 1993. Interorganizational Imitation - the Impact of Interlocks on Corporate Acquisition Activity. Administrative Science Quarterly, 38(4): 564-592.

Hayward, M. L. A. 2002. When do firms learn from their acquisition experience? Evidence from 1990-1995. Strategic Management Journal, 23(1): 21-39.

Helfat, C. E., \& Eisenhardt, K. M. 2004. Inter-temporal economies of scope, organizational modularity, and the dyanamics of diversification. Strategic Management Journal, 25(13): 1217-1232.

Hitt, M. A., Harrison, J. S., \& Ireland, R. D. 2001. Mergers \& Acquisitions: A Guide to Creating Value for Stakeholders. New York: Oxford University Press.

Hodgkinson, G. P., Herriot, P., \& Anderson, N. 2001. Re-aligning the stakeholders in management research: Lessons from industrial, work and organizational psychology. British Journal of Management, 12: S41-S48.

Hopkins, W. E., \& Hopkins, S. A. 1997. Strategic planning financial performance relationships in banks: A causal examination. Strategic Management Journal, 18(8): 635-652.

Huff, J. O., Huff, A. S., \& Thomas, H. 1992. Strategic Renewal and the Interaction of Cumulative Stress and Inertia. Strategic Management Journal, 13: 55-75.

Jaikumar, R. 1986. Postindustrial manufacturing. Harvard Business Review, 64(6): 69-76.

Karim, S. 2006. Modularity in organizational structure: The reconfiguration of internally developed and acquired business units. Strategic Management Journal, 27(9): 799-823.

Kauffman, S. A. 1993. The Origins of Order: Self-Organization and Selection in Evolution. New York: Oxford University Press.

Ketokivi, M., \& Choi, T. 2014. Renaissance of case research as a scientific method. Journal of Operations Management, 32: 232-240.

Ketokivi, M., \& Mantere, S. 2010. Two strategies for inductive reasoning in organizational research. Academy of Management Review, 35(2): 315-333.

Khandwalla, P. N. 1973. Viable and effective organizational designs of firms. Academy of Management Journal, 16: 481-495.

Khandwalla, P. N. 1977. The Design of Organizations. New York: Harcourt, Brace, Jovanovich.

King, D. R., Dalton, D. R., Daily, C. M., \& Covin, J. G. 2004. Meta-analyses of Post-Acquisition Performance: Indications of Unidentified Moderators. Strategic Management Journal, 25(2): 187-200.

Klarner, P., \& Raisch, S. 2013. Move to the beat - rhythms of change and firm performance. Academy of Management Journal, 56(1): 160-184.

Laeven, L., \& Levine, R. 2007. Is there a diversification discount in financial conglomerates? Journal of Financial Economics, 85(2): 331-367.

Lant, T. K., Milliken, F. J., \& Batra, B. 1992. The Role of Managerial Learning and Interpretation in Strategic Persistence and Reorientation - an Empirical Exploration. Strategic Management Journal, 13(8): 585-608. 
Larsson, R., \& Finkelstein, S. 1999. Integrating strategic, organizational, and human resource perspectives on mergers and acquisitions: A case survey of synergy realization. Organization Science, 10(1): 126.

Lawrence, P., \& Lorsch, J. 1967. Organization and Environment. Cambridge, MA: Harvard University Press.

Learned, E. P., Christensen, C. R., Andrews, K. R., \& Guth, W. D. 1961. Business Policy: Text and Cases. Homewood, IL: Irwin.

Lei, D., Hitt, M. A., \& Bettis, R. 1996. Dynamic core competences through meta-learning and strategic context. Journal of Management, 22(4): 549-569.

Levinthal, D. 1997. Adption on rugged landscapes. Management Science, 43: 934-950.

Levinthal, D. A., \& March, J. G. 1993. The Myopia of Learning. Strategic Management Journal, 14(Winter Special Issue): 95-112.

Li, J. 2008. Asymmetric interactions between foreign and domestic banks: effects on market entry. Strategic Management Journal, 29: 873-893.

Li, S. X., \& Berta, W. B. 2002. The ties that bind: Strategic actions and status structure in the US-investment banking industry. Organization Studies, 23(3): 339-368.

Li, S. X., \& Greenwood, R. 2004. The effect of within-industry diversification on firm performance: Synergy creation, multi-market contact and market structuration. Strategic Management Journal, 25(12): 1131-1153.

Liikanen, E. 2012. High-level Expert Group on reforming the structure of the EU banking sector: 139. Belgium: European Union Comission.

Lipton, P. 2004. Inference to the best explanation. London: Routledge.

Locke, K., \& GoldenBiddle, K. 1997. Constructing opportunities for contribution: Structuring intertextual coherence and "problematizing" in organizational studies. Academy of Management Journal, 40(5): 1023-1062.

Magnan, M. L., \& St-Onge, S. 1997. Bank performance and executive compensation: A managerial discretion perspective. Strategic Management Journal, 18(7): 573-581.

Mantere, S., \& Ketokivi, M. 2013. Reasoning in organization science. Academy of Management Review, 38(1): 70-89.

March, J. G., \& Simon, H. A. 1958. Organizations. New York: John Wiley \& Sons, Inc.

Martin, J. A., \& Eisenhardt, K. M. 2010. Rewiring: Cross-Business-Unit Collaborations in Multibusiness Organizations. Academy of Management Journal, 53(2): 265-301.

Mehra, A. 1996. Resource and market based determinants of performance in the US banking industry. Strategic Management Journal, 17(4): 307-322.

Meyer, A. D., Tsui, A. S., \& Hinings, C. R. 1993. Configurational Approaches to Organizational Analysis. Academy of Management Journal, 36(6): 1175-1195.

Miles, M. B., \& Huberman, M. A. 1994. Qualitative Data Analysis: An Expanded Sourcebook (2nd ed.). Thousand Oaks, CA: Sage.

Miles, R. H., \& Snow, C. C. 1978. Organizational Strategy, Structure, and Process. Chichester: McGrawHill.

Milgrom, P., \& Roberts, J. 1990. The economics of modern manufacturing: Technology, strategy, and organization. American Economic Review, 81: 84-88.

Miller, D. 1981. Toward a new contingency perspective: The search for organizational gestalts. Journal of Management Studies, 18: 1-26.

Miller, D. 1986. Configurations of Strategy and Structure - Towards a Synthesis. Strategic Management Journal, 7(3): 233-249.

Miller, D. 1990. The Icarus Paradox: How Exceptional Companies Bring about Their Own Downfall. New York: Harper Collins.

Miller, D. 1992. Environmental Fit Versus Internal Fit. Organization Science, 3(2): 159-178.

Miller, D. 1993. Some Organizational Consequences of Ceo Succession. Academy of Management Journal, 36(3): 644-659.

Miller, D. 1994. What Happens after Success - the Perils of Excellence. Journal of Management Studies, 31(3): 325-358.

Miller, D. 1996. Configurations revisited. Strategic Management Journal, 17(7): 505-512.

Miller, D., \& Friesen, P. 1978. Archetypes fo strategy formulation. Management Science, 24: $921-933$.

Miller, D., \& Friesen, P. 1984. Organizations: A quantum view. Englewood Cliffs, NJ: Prentice Hall.

Miller, D., \& Friesen, P. H. 1977. Strategy making in context: ten empirical archetypes. Journal of Management Studies, 14: 259-280.

Miller, D., \& Friesen, P. H. 1982. Structural-Change and Performance - Quantum versus PiecemealIncremental Approaches. Academy of Management Journal, 25(4): 867-892. 
Milliken, F. J. 1990. Perceiving and Interpreting Environmental-Change - an Examination of College Administrators Interpretation of Changing Demographics. Academy of Management Journal, 33(1): 42-63.

Mintzberg, H. 1978. Patterns in strategy formation. Management Science, 24: 934-948.

Mintzberg, H. 1979. Emerging strategy of direct research. Administrative Science Quarterly, 24(4): 582589.

Mintzberg, H. 1981. Organization Design: Fashion or Fit? Harvard Business Review(January-February 1981): 1-16.

Mintzberg, H., Lampel, J. B., Quinn, J. B., \& Ghoshal, S. 1998. The Strategy Process (Revised European Edition): Prentice Hall.

Mintzberg, H., \& McHugh, K. 1985. Strategy formulation in an adhocracy. Administrative Science Quarterly, 30: 257-272.

Mintzberg, H., \& Waters, J. A. 1985. Of strategies, deliberate and emergent. Strategic Management Journal, 6: 257-272.

Morgan, R. E., Cronin, E., \& Severn, M. 1995. Innovation in Banking - New Structures and Systems. Long Range Planning, 28(3): 91-100.

Nahapiet, J., \& Ghoshal, S. 1998. Social capital, intellectual capital, and the organizational advantage. Academy of Management Review, 23(2): 242-266.

Nelson, R. R., \& Winter, S. G. 1982. An Evolutionary Theory of the Growth of the Firm. Cambridge, MA.: Belknap Press of Harvard University Press.

Nenonen, S., \& Storbacka, K. 2010. Business model design: Conceptualizing networked value co-creation. International Journal of Quality and Service Sciences, 2(1): 43-59.

Normann, R. 2001. Reframing business: When the map changes the landscape. Chichester, UK: Wiley.

Olie, R. 1994. Shades of Culture and Institutions in International Mergers. Organization Studies, 15(3): 381405.

Palich, L. E., Cardinal, L. B., \& Miller, C. C. 2000. Curvilinearity in the diversification-performance linkage: An examination of over three decades of research. Strategic Management Journal, 21(2): 155-174.

Papadakis, V. M., Lioukas, S., \& Chambers, D. 1998. Strategic decision-making processes: The role of management and context. Strategic Management Journal, 19(2): 115-147.

Parada, P., Alemany, L., \& Planellas, M. 2009. The Internationalisation of Retail Banking: Banco Santander's Journey towards Globalisation. Long Range Planning, 42(5-6): 654-677.

Parmigiani, A., \& Howard-Grenville, J. 2011. Routines revisited: Exploring the capabilities and practice perspectives. Academy of Management Annals(5): 413-453.

Pennacchi, G. G. 1988. Loan Sales and the Cost of Bank Capital. Journal of Finance, 43(2): 375-396.

Pennings, J. M., \& Harianto, F. 1992. Technological Networking and Innovation Implementation. Organization Science, 3(3): 356-382.

Penrose, E. T. 1959. Theory of the Growth of the Firm. New York: Oxford University Press.

Petrou, A. P. 2009. Foreign Market Entry Strategies in Retail Banking: Choosing an Entry Mode in a Landscape of Constraints. Long Range Planning, 42(5-6): 614-632.

Plowman, D. A., Baker, L. T., Beck, T. E., Kulkarni, M., Solansky, S. T., \& Travis, D. V. 2007. Radical change accidentally: The emergence and amplification of small change. Academy of Management Journal, 50(3): 515-543.

Podolny, J. M. 1993. A Status-Based Model of Market Competition. American Journal of Sociology, 98(4): 829-872.

Porac, J. F., Thomas, H., \& Badenfuller, C. 1989. Competitive Groups as Cognitive Communities - the Case of Scottish Knitwear Manufacturers. Journal of Management Studies, 26(4): 397-416.

Porter, M., \& Siggelkow, N. 2008. Contextuality within activity systems and sustainability of competitive advantage. Academy of Management Perspectives, 22(2): 34-56.

Porter, M. E. 1980. Competitive Strategy: Techniques for Analyzing Industries and Competitors. New York: The Free Press.

Porter, M. E. 1996. What is Strategy? Harvard Business Review, 74(6): 61-78.

Raisch, S., \& von Krogh, G. 2007. Naviating a path to smart growth. Sloan Management Review, 48(3): 6572.

Rajan, R. G. 1992. Insiders and Outsiders - the Choice between Informed and Arms-Length Debt. Journal of Finance, 47(4): 1367-1400.

Ramaswamy, K. 1997. The performance impact of strategic similarity in horizontal mergers: Evidence from the US banking industry. Academy of Management Journal, 40(3): 697-715.

Ramezani, C. A., Soenen, L. A., \& Jung, A. 2002. Growth, Corporate Profitability, and Value Creation. Financial Analysts Journal, 58(6): 56-67. 
Richardson, M., Smith, R., \& Walter, I. 2010. Large banks and the volcker rule. Regulating Wall Street: The Dodd-Frank Act and the New Architecture of Global Finance: 181-212.

Rivkin, J. W. 2000. Imitation of complex strategies. Management Science(46): 824-844.

Robins, J., \& Wiersema, M. F. 1995. A Resource-Based Approach to the Multibusiness Firm - EmpiricalAnalysis of Portfolio Interrelationships and Corporate Financial Performance. Strategic Management Journal, 16(4): 277-299.

Romanelli, E., \& Tushman, M. L. 1994. Organizational Transformation as Punctuated Equilibrium - an Empirical-Test. Academy of Management Journal, 37(5): 1141-1166.

Rumelt, R. P. 1974. Strategy, Structure, and Economic Performance. Cambridge, Massachusetts: Harvard University Press.

Rynes, S. L., Bartunek, J. M., \& Daft, R. L. 2001. Across the great divide: Knowledge creation and transfer between practitioners and academics. Academy of Management Journal, 44(2): 340-355.

Saloner, G., \& Shepard, A. 1995. Adoption of technologies with network effects: an empirical examination of the adoption of automated teller machines. RAND Journal of Economics (RAND Journal of Economics), 26(3): 479-501.

Sanchez, R., \& Mahoney, J. T. 1996. Modularity, flexibility, and knowledge management in product and organization design. Strategic Management Journal, 17: 63-76.

Sandberg, J., \& Alvesson, M. 2011. Ways of constructing research questions: Gap-spotting or problematization? Organization(18): 23-44.

Schmenner, R. W. 1995. Service operations management: Simon \& Schuster Books for Young Readers.

Schmid, M. M., \& Walter, I. 2009. Do financial conglomerates create or destroy economic value? Journal of Financial Intermediation, 18(2): 193-216.

Schweizer, L. 2005. Organizational integration of acquired biotechnology companies into pharmaceutical companies: The need for a hybrid approach. Academy of Management Journal, 48(6): 1051-1074.

Sharpe, S. A. 1990. Asymmetric Information, Bank Lending, and Implicit Contracts - a Stylized Model of Customer Relationships. Journal of Finance, 45(4): 1069-1087.

Shaver, J. M. 2006. A Paradox of Synergy: Contagion and Capacity Effects in Mergers and Acquisitions. Academy of Management Review, 31(4): 962-976.

Siggelkow, N. 2001. Change in the presence of fit: The rise, the fall, and the renaissance of Liz Claiborne. Academy of Management Journal, 44(4): 838-857.

Siggelkow, N. 2002. Evolution toward fit. Administrative Science Quarterly, 47(1): 125-159.

Simon, H. A. 1947. Administrative Behavior: A Study of Decision Making Processes in Administrative Organizations. Chicago, IL: Macmillan.

Singh, H., \& Montgomery, C. A. 1987. Corporate Acquisition Strategies and Economic-Performance. Strategic Management Journal, 8(4): 377-386.

Singh, J. V., House, R. J., \& Tucker, D. J. 1986. Organizational-Change and Organizational Mortality. Administrative Science Quarterly, 31(4): 587-611.

Sirmon, D. G., \& Lane, P. J. 2004. A model of cultural differences and international alliance performance. Journal of International Business Studies, 35(4): 306-319.

Slager, A. M. H. 2004. Banking Across Borders: Internationalisation of the World's Largest Banks Between 1980 and 2000. Rotterdam, Holland: Erasmus Research Institute of Management: Erasmus University.

Soderberg, A. M., \& Vaara, E. 2003. Merging across borders - People, culture and politics. Copenhagen, Denmark: Copenhagen Business School Press.

Stahl, G. K., \& Voigt, A. 2008. Do cultural differences matter in mergers and acquisitions? A tentative model and examination. Organization Science, 19(1): 160-176.

Stiroh, K. J. 2004. Diversification in banking: is noninterest income the answer? Journal of Money, Credit, and Banking, 36(5): 853-882.

Stiroh, K. J. 2006. New evidence on the determinants of bank risk. . Journal of Financial Services Research, 30(3): 237-263.

Storbacka, K., \& Nenonen, S. 2011. Markets as configurations. European Journal of Marketing, 45(1/2): 241-258.

Thompson, J. D. 1967. Organizations in Action. New York: McGraw-Hill.

Toulmin, S. E. 2003. The uses of argument (updated ed.). Cambridge: Cambridge University Press.

Tushman, M. L., \& Romanelli, E. 1985. Organizational evolution: A metamorphosis model of convergerce and reorientation. In L. L. Cummings, \& B. M. Staw (Eds.), Research in Organizational Behavior: 171-222. Greenwich: JAI Press.

Vaara, E. 2002. On the discursive construction of success/failure in narratives of post-merger integration. Organization Studies, 23(2): 211-248. 
Vaara, E., \& Monin, P. 2010. A Recursive Perspective on Discursive Legitimation and Organizational Action in Mergers and Acquisitions. Organization Science, 21(1): 3-22.

Vaara, E., \& Tienari, J. 2011. On the Narrative Construction of Multinational Corporations: An Antenarrative Analysis of Legitimation and Resistance in a Cross-Border Merger. Organization Science, 22(2): 370-390.

Vaara, E., Tienari, J., \& Björkman, I. 2003. Best practice is west practice? A sensemaking perspective on knowledge transfer in a merging organization. Nordiske Organisasjonstudier, 5(1): 37-58.

Vaara, E., Tienari, J., \& Laurila, J. 2006. Pulp and paper fiction: On the discursive legitimation of global industrial restructuring. Organization Studies, 27(6): 789-810.

Vaara, E., Tienari, J., Piekkari, R., \& Santti, R. 2005. Language and the circuits of power in a merging multinational corporation. Journal of Management Studies, 42(3): 595-623.

Vaara, E., Tienari, J., \& Santti, R. 2003. The international match: Metaphors as vehicles of social identitybuilding in cross-border mergers. Human Relations, 56(4): 419-451.

Walter, I. 2009. Economic Drivers of Structural Change in the Global Financial Services Industry. Long Range Planning, 42(5-6): 588-613.

Van de Ven, A. H., \& Johnson, P. E. 2006. Knowledge for theory and practice. Academy of Management Review, 31(4): 802-821.

Van Ees, H., Gabrielsson, J., \& Huse, M. 2009. Toward a behavioral theory of boards and corporate govenrance. Corporate Governance: An International Review, 17(3): 307-319.

Wang, L., \& Zajac, E. J. 2007. Alliance or acquisition? A dyadic perspective on interfirm resource combinations. Strategic Management Journal, 28(13): 1291-1317.

Weick, K. E. 1976. Educational Organizations as Loosely Coupled Systems. Administrative Science Quarterly, 21(1): 1-19.

Weick, K. E. 1979. The social psychology of organizing. Reading, MA: Addison-Wesley.

Weick, K. E. 1989. Theory Construction as Disciplined Imagination. Academy of Management Review, 14(4): 516-531.

Venzin, M., Kumar, V., \& Kleine, J. 2008. Internationalization of retail banks: A micro-level study of the multinationality-perfomance relationship. Management International Review, 48(4): 463-485.

Whittington, R., Pettigrew, A., Peck, S., Fenton, E., \& Conyon, M. 1999. Change and complementarities in the new competitive landscape: A European panel study, 1992-1996. Organization Science, 10(5): 583-600.

Wright, P., Kroll, M., \& Elenkov, D. 2002. Acquisition returns, increase in firm size, and chief executive officer compensation: The moderating role of monitoring. Academy of Management Journal, 45(3): 599608.

Zaheer, S., Schomaker, M., \& Genc, M. 2003. Identity Versus Culture in Mergers of Equals. European Management Journal, 21(2): 185-191.

Zollo, M., \& Singh, H. 2004. Deliberate Learning in Corporate Acquisions: Post-Acquisition Strategies and Integration Capability in U.S. Bank Mergers. Strategic Management Journal, 25(13): 1233-1256.

Zott, C., \& Amit, R. 2008. The fit between product market strategy and business model: Implications for firm performance. Strategic Management Journal, 29(1): 1-26.

Zott, C., \& Amit, R. 2010. Business Model Design: An Activity System Perspective. Long Range Planning, 43(2-3): 216-226. 


\section{APPENDIX A. EVIDENCES OF NORDEA'S ACTIVITY SYSTEMS: 2000-2011}

1. Nordea Annual Report 2000: 7; Investor presentation, Fourth Quarter 2000: 23

2. Nordea Annual Report 2000: 7-8; Investor presentation, Fourth Quarter 2000: 7-8

3. Nordea Annual Report 2000: 10; board member 7.11.2014; top manager 23.1.2015

4. Nordea Annual Report 2000: 6

5. Nordea Annual Report 2000: 7

6. Nordea Annual Report 2000: 11; Investor presentation Fourth Quarter 2000: 7

7. Nordea Annual Report 2000: 19

8. Nordea Annual Report 2000: 21; top managers 26.11.2014 and 23.1.2015

9. Nordea Annual Report 2000: 19

10. Nordea Annual Report 2000: 10

11. Nordea Annual Report 2000: 27

12. Nordea Annual Report 2000: 10; Investor presentation, Fourth Quarter 2000: 7

13. Nordea Annual Report 2000: 10

14. Nordea Annual Report 2001: 22; Investor presentation, Third Quarter 2001: 6

15. Nordea Annual Report 2001: 12, 23; Investor presentation, Third Quarter 2001: 6

16. Nordea Annual Report 2001: 23, Investor presentation, Third Quarter 2001: 6

17. Nordea Annual Report 2001: 13, 23

18. Nordea Annual Report 2001: 23, Investor presentation, Third Quarter 2001: 6

19. Nordea Annual Report 2001: 23

20. Nordea Annual Report 2001: 23

21. Nordea Annual Report 2001: 10

22. Nordea Annual Report 2001: 23

23. Nordea Annual Report 2001: 23

24. Nordea Annual Report 2001: 11

25. Nordea Annual Report 2001: 11, Investor presentation, Third Quarter 2001: 7-8

26. Nordea Annual Report 2001: 22

27. Nordea Annual Report 2001: 12

28. Nordea Annual Review 2002: 18

29. Nordea Annual Review 2002: 19; Investor presentation, Fourth Quarter 2002: 54

30. Nordea Annual Review 2002: 19; Investor presentation, Fourth Quarter 2002: 55

31. Nordea Annual Report 2002: 6; Investor presentation, Third Quarter 2002: 39

32. Nordea Annual Report 2002: 7; Investor presentation, Third Quarter 2002: 40

33. Nordea Annual Review 2002: 18

34. Nordea Annual Review 2002: 18

35. Nordea Annual Review 2002: 19

36. Nordea Annual Review 2002: 19

37. Nordea Annual Review 2002: 19

38. Nordea Annual Review 2002: 6; Investor presentation, Fourth Quarter 2002: 55

39. Nordea Annual Report 2002: 6; Investor presentation, Fourth Quarter 2002: 6, 8

40. Nordea Annual Report 2002: 7; Investor presentation, Third Quarter 2002: 40

41. Nordea Annual Report 2002: 6; Investor presentation, Fourth Quarter 2002: 54

42. Nordea Annual Report 2002: 6

43. Nordea Annual Review 2002: 19

44. Nordea Annual Review 2002: 19

45. Nordea Annual Report 2002: 7; Investor presentation, Fourth Quarter 2002: 54

46. Nordea Annual Review 2003: 15

47. Nordea Annual Review 2003: 16 
48. Nordea Annual Review 2003: 17

49. Nordea Annual Review 2003: 7, 17; Investor presentation, Fourth Quarter 2003: 6

50. Nordea Annual Review 2003: 17; Investor presentation, Fourth Quarter 2003: 15

51. Nordea Annual Review 2003: 24

52. Nordea Annual Review 2003: 15

53. Nordea Annual Review 2003: 7, 17; Investor presentation, Fourth Quarter 2003: 6

54. Nordea Annual Review 2003: 16

55. Nordea Annual Review 2003: 16

56. Nordea Annual Review 2003: 17

57. Nordea Annual Review 2003: 7; Investor presentation, Fourth Quarter 2003: 6

58. Nordea Annual Review 2003: 7; Investor presentation, Fourth Quarter 2003: 11

59. Nordea Annual Review 2003: 17

60. Nordea Annual Review 2003: 17

61. Nordea Annual Review 2003: 8; Investor presentation, Fourth Quarter 2003: 15

62. Nordea Annual Review 2003: 17

63. Nordea Annual Review 2003: 17

64. Nordea Annual Review 2003: 17

65. Nordea Annual Review 2003: 8; top manager 23.1.2015

66. Nordea Annual Review 2004: 18

67. Nordea Annual Review 2004: 16; Investor presentation, Fourth Quarter 2004: 12

68. Nordea Annual Review 2004: 17; Investor presentation, Second Quarter 2004: 79

69. Nordea Annual Review 2004: 17; Investor presentation, Third Quarter 2004: 6

70. Nordea Annual Review 2004: 17; Investor presentation, Third Quarter 2004: 15

71. Nordea Annual Review 2004: 17

72. Nordea Annual Review 2004: 18

73. Nordea Annual Review 2004: 5; Investor presentation, Fourth Quarter 2004: 5

74. Nordea Annual Review 2004: 6; Investor presentation, Third Quarter 2004: 15

75. Nordea Annual Review 2004: 16

76. Nordea Annual Review 2004: 17

77. Nordea Annual Review 2004: 17

78. Nordea Annual Review 2004: 14,17; Investor presentation, Second Quarter 2004: 71

79. Nordea Annual Review 2004: 5; Investor presentation, Third Quarter 2004: 6

80. Nordea Annual Review 2004: 17; Investor presentation, Second Quarter 2004: 15

81. Nordea Annual Review 2004: 17

82. Nordea Annual Review 2004: 6

83. Nordea Annual Review 2004: 17; Investor presentation, Second Quarter 2004: 79

84. Nordea Annual Review 2004: 17

85. Nordea Annual Review 2004: 17

86. Nordea Annual Report 2005: 10

87. Nordea Annual Report 2005: 10, 15

88. Nordea Annual Report 2005: 5, 11; Investor presentation, Fourth Quarter 2005: 7

89. Nordea Annual Report 2005: 4-5

90. Nordea Annual Report 2005: 11

91. Nordea Annual Report 2005: 11

92. Nordea Annual Report 2005: 10

93. Nordea Annual Report 2005: 5, 11; Investor presentation, Fourth Quarter 2005: 6

94. Nordea Annual Report 2005: 10

95. Nordea Annual Report 2005: 11

96. Nordea Annual Report 2005: 11

97. Nordea Annual Report 2005: 4-5; Investor presentation, Fourth Quarter 2005: 7

98. Nordea Annual Report 2005: 5; Investor presentation, Fourth Quarter 2005: 12

99. Nordea Annual Report 2005: 15

100. Nordea Annual Report 2005: 11 
101. Nordea Annual Report 2005: 11

102. Nordea Annual Report 2005: 11

103. Nordea Annual Report 2005: 5

104. Nordea Annual Report 2005: 5, 11

105. Nordea Annual Report 2005: 11

106. Nordea Annual Report 2006: 10

107. Nordea Annual Report 2006: 21

108. Nordea Annual Report 2006: 3, 10; Investor presentation, Second Quarter: 16

109. Nordea Annual Report 2006: 2, 10

110. Nordea Annual Report 2006: 2-3, 10

111. Nordea Annual Report 2006: 11

112. Nordea Annual Report 2006: 10

113. Nordea Annual Report 2006: 21

114. Nordea Annual Report 2006: 4, 11

115. Nordea Annual Report 2006: 10; Investor presentation, Second Quarter 2006: 20

116. Nordea Annual Report 2006: 21; Investor presentation, Third Quarter 2006: 13

117. Nordea Annual Report 2006: 11

118. Nordea Annual Report 2006: 2-3

119. Nordea Annual Report 2006: 2-3

120. Nordea Annual Report 2006: 2,11

121. Nordea Annual Report 2006: 11

122. Nordea Annual Report 2006: 12

123. Nordea Annual Report 2006: 10; Investor presentation, Second Quarter 2006: 12

124. Nordea Annual Report 2006: 10

125. Nordea Annual Report 2006: 10

126. Nordea Annual Report 2006: 10

127. Nordea Annual Report 2007: 12

128. Nordea Annual Report 2007: 20

129. Nordea Annual Report 2007: 14; Investor presentation, First Quarter 2007: 19

130. Nordea Annual Report 2007: 12

131. Nordea Annual Report 2007: 14; Investor presentation, First Quarter 2007: 23

132. Nordea Annual Report 2007: 17; Investor presentation, First Quarter 2007: 24

133. Nordea Annual Report 2007: 20

134. Nordea Annual Report 2007: 14

135. Nordea Annual Report 2007: 14

136. Nordea Annual Report 2007: 20; Investor presentation, First Quarter 2007: 19

137. Nordea Annual Report 2007: 16

138. Nordea Annual Report 2007: 12

139. Nordea Annual Report 2007: 17; Investor presentation, First Quarter 2007: 23

140. Nordea Annual Report 2007: 12

141. Nordea Annual Report 2007: 15; Investor presentation, First Quarter 2007: 23

142. Nordea Annual Report 2007: 16

143. Nordea Annual Report 2007: 17; Investor presentation, First Quarter 2007: 23

144. Nordea Annual Report 2007: 17

145. Nordea Annual Report 2007: 13

146. Nordea Annual Report 2007: 17

147. Nordea Annual Report 2008: 9; Investor presentation, First Quarter 2008: 15

148. Nordea Annual Report 2008: 2

149. Nordea Annual Report 2008: 9; Investor presentation, First Quarter 2008: 15

150. Nordea Annual Report 2008: 8; Investor presentation, First Quarter 2008: 10

151. Nordea Annual Report 2008: 11; Investor presentation, First Quarter 2008: 15

152. Nordea Annual Report 2008: 11

153. Nordea Annual Report 2008: 9; Investor presentation, First Quarter 2008: 15 
154. Nordea Annual Report 2008: 10; Investor presentation, First Quarter 2008: 15

155. Nordea Annual Report 2008: 10; Investor presentation, First Quarter 2008: 17

156. Nordea Annual Report 2008: 9

157. Nordea Annual Report 2008: 10

158. Nordea Annual Report 2008: 8

159. Nordea Annual Report 2008: 2; Investor presentation, First Quarter 2008: 85

160. Nordea Annual Report 2008: 2

161. Nordea Annual Report 2008: 11

162. Nordea Annual Report 2008: 11

163. Nordea Annual Report 2008: 10

164. Nordea Annual Report 2008: 11

165. Nordea Annual Report 2008: 8

166. Nordea Annual Report 2009: 11

167. Nordea Annual Report 2009: 10

168. Nordea Annual Report 2009: 9; Investor presentation, First Quarter 2009: 8

169. Nordea Annual Report 2009: 8; Investor presentation First Quarter 2009: 7

170. Nordea Annual Report 2009: 12; Investor presentation, First Quarter 2009: 7

171. Nordea Annual Report 2009: 12

172. Nordea Annual Report 2009: 9

173. Nordea Annual Report 2009: 9

174. Nordea Annual Report 2009: 10; Investor presentation, First Quarter 2009: 8

175. Nordea Annual Report 2009: 10

176. Nordea Annual Report 2009: 10

177. Nordea Annual Report 2009: 8

178. Nordea Annual Report 2009: 8; Investor presentation, First Quarter 2009: 8

179. Nordea Annual Report 2009: 8; Investor presentation, First Quarter 2009: 8

180. Nordea Annual Report 2009: 12

181. Nordea Annual Report 2009: 12

182. Nordea Annual Report 2009: 8

183. Nordea Annual Report 2009: 12

184. Nordea Annual Report 2009: 12

185. Nordea Annual Report 2009: 9

186. Nordea Annual Report 2010: 17

187. Nordea Annual Report 2010: 18; Capital Markets Day 2010 presentation: 25

188. Nordea Annual Report 2010: 17; Capital Markets Day 2010 presentation: 16

189. Nordea Annual Report 2010: 2; Capital Markets Day 2010 presentation: 7

190. Nordea Annual Report 2010: 19; Capital Markets Day 2010 presentation: 16

191. Nordea Annual Report 2010: 19; Capital Markets Day 2010 presentation: 35

192. Nordea Annual Report 2010: 17: Capital Markets Day 2010 presentation: 16

193. Nordea Annual Report 2010: 18

194. Nordea Annual Report 2010: 18; Capital Markets Day 2010 presentation: 22

195. Nordea Annual Report 2010: 18

196. Nordea Annual Report 2010: 16; Capital Markets Day 2010 presentation: 9

197. Nordea Annual Report 2010: 16; Capital Markets Day 2010 presentation: 9

198. Nordea Annual Report 2010: 16; Capital Markets Day 2010 presentation: 9

199. Nordea Annual Report 2010: 19

200. Nordea Annual Report 2010: 17; Capital Markets Day 2010 presentation: 17

201. Nordea Annual Report 2010: 19

202. Nordea Annual Report 2010: 17; Capital Markets Day 2010 presentation: 16

203. Nordea Annual Report 2010: 19

204. Nordea Annual Report 2010: 16

205. Nordea Annual Report 2011: 11

206. Nordea Annual Report 2011: 12; Capital Markets Day 2011 presentation: 36 
207. Nordea Annual Report 2011: 9; Capital Markets Day 2011 presentation: 25

208. Nordea Annual Report 2011: 12

209. Nordea Annual Report 2011: 12

210. Nordea Annual Report 2011: 12

211. Nordea Annual Report 2011: 9

212. Nordea Annual Report 2011: 9

213. Nordea Annual Report 2011: 4

214. Nordea Annual Report 2011: 4

215. Nordea Annual Report 2011: 13

216. Nordea Annual Report 2011: 13; Capital Markets Day 2011 presentation: 34

217. Nordea Annual Report 2011: 4, 9; Capital Markets Day 2011 presentation: 32

218. Nordea Annual Report 2011: 9

219. Nordea Annual Report 2011: 4

220. Nordea Annual Report 2011: 12

221. Nordea Annual Report 2011: 12

222. Nordea Annual Report 2011: 4;Capital Markets Day 2011 presentation: 32

223. Nordea Annual Report 2011: 4; Capital Markets Day 2011 presentation: 37

224. Nordea Annual Report 2011: 12

225. Nordea Annual Report 2011: 16 


\section{APPENDIX B. FURTHER DETAIL ON THE RESEARCH CONTEXT}

This appendix provides further detail on the banking industry. This detail enables the reading to further reflect how my findings are related to the context of the firm that I studied. While in the main body of the text, I focused on the key characteristics of industry, this appendix focuses on business models for banks, competitive advantages, consolidation and acquisitions, and technological transformation and innovations in the banking industry.

\section{Retail, investment, and wholesale banks}

In one report of the business models of 26 major European banks before and after the global financial crisis (2007-2009), the authors found three major alternative business models for banks: retail banking, investment banking, and wholesale banking (Ayadi et al., 2011). Retail banks are banks that use customer deposits as the primary source of funding and predominately provide customer loans, transaction services, credit cards, and investment products (like mutual funds) for their customers. Retail banks offer a range of financial services to individuals and small and medium-sized enterprises. Investment banks are banks with massive trading and derivatives activities. In investment banking business banks also underwrite stock and bond issues, and provide advisory services for customers. Wholesale banks are active in the wholesale and interbank markets with a focus on domestic business. Wholesale and investment banks provide their customers (large corporations) with services such as corporate finance, underwriting, securities issues, and other banking services.

Retail banks can implement their international expansion strategy with different models of foreign entry like acquisitions, start-ups (green field operations), and joint ventures. When a retail bank enters a foreign market, it faces at least three critical challenges. The bank has to have a good local brand and reputation because its products are intangible and trust-based, and credibility is important in retail banking. Another challenge is to reach a large enough customer base within a reasonable timescale. The third challenge is the need for local market knowledge and know-how 
(Petrou, 2009). Local banking regulations can create barriers to the entry of foreign banks. In this kind of situation some banks have used joint ventures to avoid these challenges. For example in China, many foreign banks like HSBC and Royal Bank of Scotland (RBS) have entered the Chinese banking market via joint ventures with Chinese state-owned banks. If there are foreign banks in a particular market segment, it may actually signal favorable market opportunities for domestic banks and thus encourage new domestic entries (Li, 2008).

Morgan, Cronin, \& Severn argue that the winners among the retail banks have been and will be the organizations that recognize changes in the market environment quickly enough and respond to them effectively. According to their study, the increasing of organizational effectiveness is a key success factor for retail banks, and therefore service innovations and the use of sophisticated customer segmentation have an important role in developing the effectiveness of a retail bank (Morgan, Cronin, \& Severn, 1995).

A bank's strategic domain depends on its service orientation; whether a bank's customer market is a wholesale or retail market. Wholesale banking involves inherently complex decision making and, in contrast, retail banking involves highly structured tasks and small-scale transactions. Therefore wholesale banking executives need more discretion in their decision making than do retail banking executives (Magnan \& St-Onge, 1997).

During recent decades banks have significantly expanded their activities, and other activities have become increasingly important, like asset management services, market making activities, and dealing and broking for institutional investors and corporates as well as for hedge funds. Banks have also been active in proprietary trading. A bank may reduce costs due to complementarities in production (the costs of the economies of scope) or raise revenues from complementarities in consumption (revenue from the economies of scope) by providing financial services jointly to its clients (Berger, Humphrey, \& Pulley, 1996).

In the investment banking industry banks are not only competing on the basis of price and service quality, they are also competing for relationships. The status hierarchy 
reflects the most important structural property of the industry (Li \& Berta, 2002). The leading industry magazines, such as the Institutional Investor and Euromoney, regularly publish rankings of the investment banks, and an investment bank's status is used by other firms to conclude the quality of this bank's products and skills (Podolny, 1993). An investment bank's connection to other high-status investment banks constitutes valuable social capital for this investment bank (Nahapiet \& Ghoshal, 1998).

The growth in banks' new activities has meant a substantial lengthening of the intermediation chains between ultimate lenders and ultimate borrowers and has dramatically increased counterparty risk and interconnectivity within the banking sector (Richardson, Smith, \& Walter, 2010). This expansion has meant that they have incorporated new activities that may more or less fit well with their previous core activities. Hence, banks have been influenced by their ability to develop fit, and the processes relating to fit development should be particularly visible in banks.

In the banking industry, the size of a bank is most frequently measured by its total assets, although Salonen and Shepard (1995) measure it as the number of branches. Academic research on banks conducted in industrial organization economics suggests that market share increases performance. According to some studies, larger banks can dominate the market by aggressive pricing and can also be more efficient (Demsetz, 1973; Gale, 1972). The performance of banks varies with different strategies. According to one study, an increased focus on non-traditional banking, particularly on trading operations, reduces the risk-adjusted profitability of banks (Stiroh, 2004). Some scholars have found empirical evidence that investment banking, securitization, and trading are highly volatile banking operations (DeYoung \& Roland, 2001; Stiroh, 2006).

To summarize, in the main results of one study retail banks were the institutions that were least leveraged and had taken fewer risks while performing comparably to their peers (Ayadi et al., 2011). The study also pointed out that the retail banking model is safer than the others and that there are some weaknesses of the investment banking model, which tends to rely on less stable funding sources, to engage heavily in 
trading activities, and tends to maintain a very low share of loss-absorbing capital compared to the other two models.

What is the role of diversification in terms of a bank's profitability? The relationship between banks' divergent strategies toward specialization and the diversification of financial activities, and their ability to withstand a banking sector crash has been studied in the banking literature. According to one study, diversifying financial activities under an umbrella institution does not improve banking system stability, which may explain why financial conglomerates trade at a discount (De Jonghe, 2010). One study pointed out that diversified banks are often less profitable than focused banks (Berger, Hasan, \& Zhou, 2010). DeYoung and Roland (DeYoung \& Roland, 2001) found that a shift toward fee-based activities is associated with increased revenue volatility and a higher degree of total leverage. In the literature it has also been found that a greater reliance on non-interest income, especially on trading revenue, is merged with higher risk and lower risk-adjusted profits across banks (Stiroh, 2004). One conclusion has been that the choice of strategy has implications for the market value of a bank. Some scholars have found that diversified banks trade at a discount (Laeven \& Levine, 2007; Schmid \& Walter, 2009). However, there is no fit consideration in these studies that compare the basic business models - that is, the categories they use are too crude to lead to meaningful findings.

When asset prices increase, banks' balance sheets generally become stronger, and-without adjusting asset holdings-their leverage tends to be too low. Then banks hold surplus capital and will attempt to find ways in which they can employ their surplus capital. On the asset side, they search for potential borrowers, and on the liability side, they take on more short-term debt (Adrian \& Shin, 2010). The European Central Bank's study (2011) concludes that institutions with higher risk exposure had less capital, larger size, greater reliance on short-term market funding, and aggressive credit growth. Less risky business models were characterized by a strong deposit base and greater diversification. 


\section{Competitive advantages in the banking industry}

In his book Competitive Strategy (Porter, 1980) introduced the concept of generic strategies-cost leadership, differentiation, and focus-to represent the alternative strategic positions in an industry. Competitive strategy is about being different by choosing a different set of activities to deliver a unique mix of value (Porter, 1996). This is also the case in the banking industry. Strategic focus is relevant to strategic complementarity because it has an impact on a firm's product strategy, risk-taking policy, resource allocation patterns, managerial capabilities, and growth orientation (Helfat \& Eisenhardt, 2004). All those issues are also relevant in the banking industry.

The concept of competitive advantage emphasizes a firm's relative position (Porter $1985,1991)$. In some academic studies strategy is conceptualized as a firm's realized position in its competitive market. A firm's strategic position relative to the strategic positions of competing firms influences a performance construct (Barney, 1991; Porter, 1980). A bank's strategic positions can be based on customers' needs (needs-based positioning), customers' accessibility (access-based positioning), or the variety of a company's products or services (variety-based positioning). Positioning is no longer at the heart of strategy because of today's dynamic markets and changing technologies. Today a bank's rivals can quickly copy any market position, and therefore competitive advantage is only temporary. For example, competitors can quickly imitate new technologies, production, and management techniques as well as customer service concepts (Porter, 1996).

The assumption that strategy is related to the competitive environment is a fundamental one in strategic management (Porter, 1980). A firm faces less competition for resources if it has a different strategy. Rational differentiation reduces competition and increases performance (Baum \& Mezias, 1992; Baum \& Singh, 1994). A firm's choice of position is particularly strong when it has developed an internal fit matching that position (Porter, 1996). In such a situation, competitors are unlikely to quickly copy the position because they will have difficulties in making all the interdependent changes required (cf. Siggelkow, 2002). 
According to Deephouse (1999) a firm should be balanced between differentiation and conformity. The level where a firm achieves maximum performance is at the level of strategic similarity, where the gains from reduced competition are equal to the costs of legitimacy challenges, which is the balancing point between differentiation and conformity pressures (Porac, Thomas, \& Badenfuller, 1989).

Why are some banks consistently more profitable than others? What are key competitive advantages in the banking industry? Ajay Mehra (Mehra, 1996) explored the implications of studying the banking industry's competitive patterns at the level of resource accumulation and also the relationship between resource endowments and firm performance outcomes in the US banking industry and how these qualities translate into competitive advantages for a bank.

Ajay Mehra defined 10 key resources that provide a sustainable competitive advantage in the banking industry. These are; (1) management quality and depth, (2) a franchise, (3) asset/credit quality, (4) technological expertise, (5) placing power, (6) the adequacy of the capital base, (7) resource management/efficiency, (8) innovation, (9) risk management, and (10) information asymmetries. His arguments have become influential in the banking industry: It is important to go through them in detail.

According to Mehra (1996) the most critical resource in establishing a sustainable competitive advantage is the quality and depth of a bank's management team. A bank has to have a clear strategic vision and a high-quality management team to attract and retain high-quality employees. Compensation and reward systems are key elements in developing a sustainable competitive advantage for a bank. However, Mehra does not elaborate sufficiently on how these qualities translate into competitive advantages for a bank.

The second key resource is a franchise, and the strategic management research also emphasizes a corporate reputation's role as a competitive advantage (Mehra, 1996). A good franchise and brand image helps to attract new customers and to keep current customers. The third key resource is asset and credit quality. If a bank has 
good credit quality, it has usually also has a good credit rating, which means a lower funding cost for the bank.

The fourth key resource that provides sustainable competitive advantage in the banking industry is a bank's technological expertise. The management of new technologies has received increasing attention in strategic management research (Greve, 2009). The continual introduction of new technologies, and the shortening lifecycles of innovations and their fast rates of diffusion have caused complex challenges for companies (Bettis \& Hitt, 1995). The banking industry is a highly knowledge-intensive industry, and technological systems and capabilities can provide a tremendous advantage in the banking industry (Mehra, 1996). For a bank, advanced technology can mean both an ability to provide better services for its customers and better efficiency. However, Mehra did not discuss the factors that influence if and how new technology fits with established operations and the customer service model. Some scholars have made the very important finding that there is no relationship between the absolute level of technology use and profitability (Fuentelsaz, Gómez, \& Palomas, 2012). According to their study technology-based competitive advantage can be obtained even when the technology has become a commodity.

According to Mehra (1996) the fifth key resource is a bank's placing power and this represents the financial muscles and the distribution capabilities of a bank. Placing power is particularly important in investment banking, and its role has increased because of a growth of securitization in the global financial markets. The sixth key resource is the adequacy of the capital base. A high equity ratio and a strong capital structure are the determinants of a bank's risk-bearing ability and they help in achieving regulatory compliance. A strong capital base also helps to reduce the cost of funding.

The seventh key resource results from resource management and efficiency. With good resource management and high efficiency in its operations, a bank can lower its fixed cost base and improve its profitability and competitiveness. The eighth key resource in the creation of competitive advantage is innovation, and innovations in the banking industry are typically new ways to provide banking services or totally new 
products for customers. New products and services are important for growth in the banking industry and speed-to-market is critical in securing competitive advantage for a bank. The adoption of new technology has been a key in new product development and a new software platform can support rapid innovations, for example, in a bank's credit card business (Drew, 1995).

According to Mehra (1996) the ninth key resource is risk management. Good risk management is the ability of a bank to prudently manage and evaluate the risks of its business portfolio (like credit risks, interest rate risks, foreign exchange rate risks, funding risks, counterparty risks, and different operational risks). Good risk management means, for example, less credit losses in a bank's credit portfolio, and it thus improves the bank's profitability. High-quality risk management can be a competitive advantage to a bank.

The tenth key resource that provides a sustainable competitive advantage in the banking industry is information asymmetries. Banking is a highly informationintensive business and a bank has to aggregate, process, and evaluate a large amount of different customer information. Thus a bank gains valuable information on its clients that might provide advantages in selling other services and products to them (Rajan, 1992; Sharpe, 1990). With a wide range of activities, banks may reduce their risks through diversification and economies of scope (Diamond, 1984).

Also, other scholars have recognized other factors as central for a bank's success. If a bank has foreign operations, it can provide a more effective service to its multinational customers and its global network ensures more efficient cash management and payment solutions for its customers. By internationalization a bank can create a competitive advantage for its whole business (Petrou, 2009). On the other hand, one study of international banking concluded that foreign activities are less profitable than domestic activities, and banks that increased their international activities (either strongly or moderately) generated least shareholder value (Slager, 2004). Another study confirms that among five leading European banks there was no consistent relationship between internationalization and profitability between 2000 and 2004 (Venzin, Kumar, \& Kleine, 2008). In the EU banking industry only a little improvement in cost efficiency or profitability has resulted from cross-border mergers 
and acquisitions, and in-country banking mergers have been significantly more successful than cross-border mergers (Ayadi \& Pujals, 2004). According to one study the gains from internationalization vary enormously, and the primary source of the gains is the translocation of firm-specific competitive advantages based on characteristic resources and capabilities (Grant \& Venzin, 2009).

It has been suggested that in services industries like the banking industry, where competition can move very quickly and new players can enter easily, there is a constant need to think strategically about what is going on (Schmenner, 1995).

In response to increasing complexity and change in the financial services industry, banks have turned to strategic planning. Inconsistent results of bank-related research, however, have not fully resolved the issue of whether strategic planning leads to improvements in banks' financial performances (Hopkins \& Hopkins, 1997). The intensity with which banks engage in the strategic planning process has a direct, positive effect on banks' financial performances, and forwards the effects of managerial and organizational factors in banks' performances. However, while planning is important, the ways in which emergent processes shape a bank's strategies remains less well understood, and therefore it might be that what looks like careful planning is actually (in retrospective analysis) the outcome of skillful adaptations from which a strategic pattern emerges.

In the early 2000s many listed banks already started to communicate more openly about their strategy; their long-term financial targets, and their key business areas and geographical focus areas. The transparency of the banking industry, especially among the listed banks, has increased dramatically in the last decade.

The academic research has noticed that fit is a more central component of competitive advantage than most realize. According to Porter (1996) a strategy is about combining different activities and creating fit among a company's activities. Strategic fit is fundamental both in the creation of competitive advantage and in maintaining the sustainability of that advantage. 


\section{Consolidation in the banking industry}

Globalization has meant the integration of financial markets throughout the world into one global financial market. There has been rapid international expansion in the financial services industry since the early 1990s. Particularly the world's major banks and insurance companies have accelerated this development. Numerous banks have increased their businesses in new markets and today there are more and more global banks, which have branches and offices at all the key and relevant places in the world.

The main drivers for consolidation have been advanced transaction and information technologies, regulatory movements, a geographic shift in growth opportunities, and the rapid evolution of client requirements. It has meant strategic turbulence in banks and their board rooms (Walter, 2009). In retail banking extensive overcapacity in some countries has led to substantial consolidation. Excess retail production and distribution capacity have been slimmed-down (Walter, 2009).

Over the last decade there has been a significant increase in cross-border entries and in many cases banks have used both joint ventures and acquisitions to expand their business abroad. Cross-border mergers were still rare in the late 1990s, and there were no pan-European banks that had more than two home markets, despite the ongoing EU integration process. Cross-border mergers and acquisitions are often driven by scale and efficiency considerations, and thus it is a question of an emergent renewal story (Flier et al., 2001). Opportunism and imitation are also identified as drivers for cross-border expansion (Grant \& Venzin, 2009). Mimetic behavior seems to be typical for banking: for example, if one bank opens new branches in supermarkets, all the banks follow it, or if one bank goes into internet banking, all the banks go into internet banking. In the academic literature there is a lot of evidence that imitation is a central issue for many banks. Local rivalries have stimulated imitation of international strategies: these kind of rivalries have been obvious between the Spanish banks BBVA and Banco Santander, as well as between the Swiss banks Credit Suisse and UBS (Grant \& Venzin, 2009). 
The Scandinavian countries have seen significant and successful cross-border mergers. An example of a successful cross-border merger is MeritaNordbanken. After the merger, the bank's top management tried to establish a completely new entity and immediately started a process of integrating the two banks (Flier et al., 2001). MeritaNordbanken became a part of Nordea, the leading Nordic bank, and therefore it is optimal for a study of fit development over time, especially in regard to Nordea's business strategy. Some scholars have seen the case of Nordea as pioneering in the European banking industry as it involves the merging process between leading retail banks that were originally operating in four different countries (Vaara, Tienari, Piekkari, \& Santti, 2005).

It is predicted that the European financial services industry will be lifted to another level of turbulence in the twenty-first century (Flier et al., 2001). After domestic markets have been consolidated, the next wave of both cross-border and crosssector consolidation will take place. However, the global financial crisis of 2008 has impacted this development, and the speed of cross-border consolidation has been slower than expected.

One study described and analyzed Banco Santander's transformation from a medium-sized Spanish bank to one of the world's biggest and most profitable banks (Parada, Alemany, \& Planellas, 2009). The study identified a systematic pattern in Banco Santander's international growth. There were three steps in the process: 1) building capabilities in the home market, 2) creating growth options in foreign markets through small-scale acquisitions or strategic alliances, and 3) large-scale foreign market entry and rapid integration. One of the value drivers in the integration process was that the bank consistently identified retail banking services as the group's core business. Another value driver was a cost-efficient information and communication technology (ICT) to optimize risk control and information access because an effective way to create value from a cross-border acquisition is to reduce the cost-to-income ratio of the acquired bank by using the parent bank's IT systems in the acquired bank. While the existing management research has recognized that fit between organizational activities is an important determinant of success, it does not sufficiently explain how a bank such as Banco Santander developed and maintained strategic fit or how other banks could do the same. 
The fundamental challenge of internationalization in the banking industry is how to achieve economies from cross-border integration when the production of services is highly decentralized, and this challenge is even greater in the retail banking industry because of local regulations in the separate national market (Parada et al., 2009). On the other hand, non-traditional technologies and new business models might make it easier to offer banking services around the clock to customers anywhere, and thus this kind of development might partly replace the need to make difficult-to-manage mergers and acquisitions (Flier et al., 2001). As Siggelkow's (2001, 2002) work suggests, a company can develop its strategic fit by patching (the creation of a new core element and its reinforcement by new elaborating elements). When a bank is using non-traditional technologies and new business models, it is developing its strategic fit by patching.

\section{Acquisitions}

One way that banks can grow and adapt to environmental changes is through acquisitions. Rather than developing new activities from scratch, they can acquire existing companies and integrate their activities with their own. Global acquisition volume hit an all-time record high of $\$ 3.79$ trillion in 2006 (Thompson Financial, 2007). The high transaction volume is one reason why acquisitions have been studied actively. It is very interesting that, for example, two meta-analyses (Datta, Pinches, \& Narayanan, 1992; King, Dalton, Daily, \& Covin, 2004) suggest that most acquisitions fail. Many scholars have studied the success of acquisitions and explored determinants of acquisition performance. These studies have realized that the success of acquisitions depends on synergy realization (Haspeslagh \& Jemison, 1991; Hitt, Harrison, \& Ireland, 2001; Larsson \& Finkelstein, 1999). There are also many studies of the success of synergy realization, which depends on prudent acquisition target selection (Barney, 1988; Harrison, Hitt, Hoskisson, \& Ireland, 1991; Ramaswamy, 1997; Singh \& Montgomery, 1987) or on effective post-merger integration (Chatterjee, Lubatkin, Schweiger, \& Weber, 1992; Datta, 1991; Haspeslagh \& Jemison, 1991; Larsson \& Finkelstein, 1999). 
Acquisitions are a challenging area from the top management's point of view. Some scholars have concluded that learning from prior experience may be pivotal in attempting to enhance the performance of mergers and acquisitions (Lei, Hitt, \& Bettis, 1996). For example, US conglomerate General Electric has managed its acquisition process considering that it is possible to effectively integrate most of its acquisitions within 100 days (Ashkenas, DeMonaco, \& Francis, 1998). In the academic literature a positive relationship has been found between experience and performance (Barkema, Bell, \& Pennings, 1996; Fowler \& Schmidt, 1989). However, there are also studies in which no relationship (or an insignificant relationship) between experience and performance has been found (Bruton, Oviatt, \& White, 1994; Hayward, 2002; Wright, Kroll, \& Elenkov, 2002; Zollo \& Singh, 2004). Based on the knowledge-based view of corporate acquisitions, in their study Zollo and Singh (2004) found (from among a sample of 228 acquisitions in the US banking industry) that knowledge codification strongly and positively influences acquisition performance, while experience accumulation does not. Increasing levels of postacquisition integration strengthen the positive effect of codification, and the level of integration between the two merged firms significantly enhances performance, while replacing top managers in the acquired firm negatively impacts performance. However, firms may also learn from other firms, based on the sociological theory of imitation (Dimaggio \& Powell, 1983). According to one study among large acquisitions of US corporates, firms imitate the acquisition behavior of other firms, for example when they were hiring an investment bank their decision was based on how often others had used that bank (frequency-based imitation) (Haunschild, 1993).

Based on the resource-based view of the firm, some scholars have argued that it is the complementarity of acquirer and target that is one of the most significant factors in an acquisition's success (Capron, Dussauge, \& Mitchell, 1998; Wang \& Zajac, 2007). Complementary differences between the acquirer and target companies can create value for the combined firm and provide opportunities to develop competencies that neither firm could create alone (Harrison et al., 1991). If firms in related businesses share similarities in culture, management style, and administrative processes, they can leverage their pre-existing resources and capabilities with their merging partner and its business (Palich, Cardinal, \& Miller, 2000; Robins \& 
Wiersema, 1995). Similarity between merging firms is the primary source of strategic fit that improves acquisition performance.

Acquisitions that bring together firms competing in different geographic markets offer opportunities for creating value when the attributes of the market in which the target firm has its competences are different, but mutually reinforce the acquirer's market characteristics (Li \& Greenwood, 2004; Zollo \& Singh, 2004). For example, if there are two banks and one bank has access to large deposit volumes and the other bank is strong in the commercial lending market, when these two banks merge, the combined bank can utilize these resources more efficiently by allocating capital from the retail funding market to the market with greater profit margin. Thus the combined bank can cut its operating costs, increase revenues, and achieve higher margins.

Why is it so challenging to be successful in acquisitions? One reason is that acquisitions are much more complex than activities at the operating level, and the acquisition process consists of many interdependent activities, like due diligence, funding, and integration, each of which is complex in itself (Hitt et al., 2001). Another reason could be that every acquisition is a unique case, and therefore previous experience does not help to create success in the next acquisition. From a company's top management's point of view it is important to develop strategic fit gradually in acquisition cases.

\section{Technological transformation and innovations in the banking industry}

In the banking industry innovations can be like new processes or techniques that provide significant value to the customers as well as a good return for the bank. Internet banking constitutes an important innovation in the financial sector.

In the previous literature a positive relationship between the size of a financial company and the adoption of new technologies was found (Hannan \& McDowell, 1984; Pennings \& Harianto, 1992). However, some scholars, like Pennings and Hariano (1992), emphasized that the growing importance of external sources of technology might reduce the role of size as a determinant in the adoption of new technologies. This positive relationship between size and the adoption of 
technological innovations is generally explained in terms of the economies of scale (Corrocher, 2006).

When a large bank is providing innovative services, it can reduce its average costs much more than a small bank can because its transaction volumes and amount of customers are much larger. In his study Corrocher (2006) found that medium-sized banks were the first movers in the adoption of internet banking, implying that a certain degree of the economies of scale exists. Also, an earlier study on the adoption of ATMs by banks supports the hypothesis of the positive relationship between size and the adoption of technological innovations. According to this study banks with many branches adopted ATMs earlier than banks with fewer branches (Saloner \& Shepard, 1995).

It is interesting that the previous literature does not support the hypothesis that there would be a significant relationship between the profitability of a bank and the adoption of new technologies (Hannan \& McDowell, 1984; Pennings \& Harianto, 1992). This might be because the previous studies have not fully considered how the novel technology was matched with the banks' other operations-it might be that a high fit boosts performance, while a fit-destroying introduction has the opposite effect. Because technological expertise is a key resource in the banking industry and efficiency is a key element of successful banking business, a technologically advanced bank should have better capabilities to improve its efficiency, and thus also profitability, by using new technological solutions.

New products are important for growth in the banking industry and speed-to-market is critical in securing competitive advantage for a bank (Drew, 1995). The adoption of new technologies is key in new product development and a new software platform can support rapid innovations, for example in a bank's credit card business. But when a bank invests in new technologies, it has to take into account the impact of technological innovations on the existing branch network (Corrocher, 2006).

Innovations are important in developing new product and services. For the last decade there have been a lot of financial innovations, some of them have been new 
instruments for risk management and some of them have been, for example, new investment instruments and opportunities to customers.

Asset securitization was already a key financial innovation in the 1980s, but it especially had a significant role in investment banking in the 2000s. Pennacchi (Pennacchi, 1988) pointed out that securitization was going to be a fundamental change in the commercial banking business. Securitization allows banks to obtain liquidity from assets that cannot be sold in liquid markets. Regulation has played a key role in the development of the securitization market.

Banks need to hold a minimum level of regulatory capital and they try to optimize the use of equity capital. Optimizing capital use is therefore one of the incentives to securitize. In the 2000s Spain was a country where banks resorted to securitization in an increasing way. In 2007 more than $25 \%$ of the bank mortgage portfolios were securitized, either directly or through covered bonds (Martin-Oliver \& Saurina, 2007). By securitization a bank can use its equity capital in a more efficient way and then leverage its financial performance and return on equity (ROE).

Asset securitization means a process that includes the pooling of various types of loans and debts (such as residential mortgages, commercial mortgages, or credit card debt obligations) and then selling this kind of consolidated debt as bonds or other securitized instruments to investors. Securities backed by mortgage receivables are called mortgage-backed securities and securities backed by other type of receivables are asset-backed securities. Banks are using securitization as a procedure through which they can sell a part of their assets to obtain liquidity, to change the risk profile in their credit portfolio, and to arbitrage capital requirements.

The success of securitization shows that it is a more efficient method for linking borrowers and investors than traditional financing through financial intermediaries, like commercial banks. The securitization of bank loans has grown significantly in the 2000s and it played a key role in the US subprime loan crisis between 2007 and 2008. Rapid innovation in very sophisticated products like derivatives can be a contributing factor to financial disasters like the US subprime loan crisis. 
The global financial crisis that began in 2007 has illustrated how easily new financial innovations can go off the rails and result in disaster. Financial engineers and investment bankers can design complex (and from their point of view profitable) products that many investors and asset managers fail to fully understand but are still ready to invest in them. 




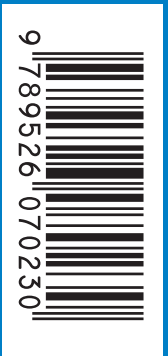

ISBN 978-952-60-7023-0 (printed)

ISBN 978-952-60-7022-3 (pdf)

ISSN-L 1799-4934

ISSN 1799-4934 (printed)

ISSN 1799-4942 (pdf)

Aalto University

School of Science

Industrial Engineering and Management

www.aalto.fi

\author{
BUSINESS + \\ ECONOMY \\ ART + \\ DESIGN + \\ ARCHITECTURE \\ SCIENCE + \\ TECHNOLOGY \\ CROSSOVER \\ DOCTORAL \\ DISSERTATIONS
}

